\title{
De arbeidsmarkt naar opleiding en beroep tot 2000.
}

Citation for published version (APA):

Researchcentrum voor Onderwijs en Arbeidsmarkt, ROA. (1996). De arbeidsmarkt naar opleiding en beroep tot 2000. Statistische bijlage. Actualisering 1996. Researchcentrum voor Onderwijs en Arbeidsmarkt, Faculteit der Economische Wetenschappen. ROA Reports No. 008B https://doi.org/10.26481/umarep.1996008B

Document status and date:

Published: 01/01/1996

DOI:

10.26481/umarep.1996008B

Document Version:

Publisher's PDF, also known as Version of record

\section{Please check the document version of this publication:}

- A submitted manuscript is the version of the article upon submission and before peer-review. There can be important differences between the submitted version and the official published version of record.

People interested in the research are advised to contact the author for the final version of the publication, or visit the DOI to the publisher's website.

- The final author version and the galley proof are versions of the publication after peer review.

- The final published version features the final layout of the paper including the volume, issue and page numbers.

Link to publication

\footnotetext{
General rights rights.

- You may freely distribute the URL identifying the publication in the public portal. please follow below link for the End User Agreement:

www.umlib.nl/taverne-license

Take down policy

If you believe that this document breaches copyright please contact us at:

repository@maastrichtuniversity.nl

providing details and we will investigate your claim.
}

Copyright and moral rights for the publications made accessible in the public portal are retained by the authors and/or other copyright owners and it is a condition of accessing publications that users recognise and abide by the legal requirements associated with these

- Users may download and print one copy of any publication from the public portal for the purpose of private study or research.

- You may not further distribute the material or use it for any profit-making activity or commercial gain

If the publication is distributed under the terms of Article $25 \mathrm{fa}$ of the Dutch Copyright Act, indicated by the "Taverne" license above, 


\section{Statistische Bijlage \\ De arbeidsmarkt naar opleiding en beroep tot $\mathbf{2 0 0 0}$}

Actualisering 1996

ROA-R-1996/8B

Researchcentrum voor Onderwijs en Arbeidsmarkt

Faculteit der Economische Wetenschappen en Bedrijfskunde

Universiteit Maastricht

Maastricht, oktober 1996 
Niets uit deze uitgave mag worden verveelvoudigd en/of openbaar gemaakt door middel van druk, fotokopie, microfilm, of op welke wijze ook, zonder voorafgaande schriftelijke toestemming van de directeur van het Researchcentrum voor Onderwijs en Arbeidsmarkt. In geval van overname van het datamateriaal moet telkens duidelijk als bron worden vermeld: "Researchcentrum voor Onderwijs en Arbeidsmarkt" of "ROA". Van publicaties waarin gebruik wordt gemaakt van gegevens uit deze Statistische Bijlage ontvangen wij gaarne een exemplaar.

Hoewel de grootst mogelijke zorg is besteed aan de inhoud van dit rapport, kan het ROA in genelei opzicht verantwoordelijkheid op zich nemen voor eventuele onvolledigheden of onjuistheden. 


\section{Inhoudsopgave}

Bladzijde

$\begin{array}{lr}\text { Voorwoord } & \text { i } \\ \text { Toelichting bij het gebruik } & \text { v } \\ \text { Ontwikkelingen op de arbeidsmarkt } & \text { vii }\end{array}$

\section{INFORMATIE OVER BEDRIJVEN}

Figuren

1.1 Verwachte uitbreidingsvraag per bedrijfssector, 1995-2000

Tabellen

1.1 Aantal werkenden per bedrijfssector, gemiddelde 1994-1995 2

1.2 Percentage vrouwen per bedrijfssector, gemiddelde 1994-1995

1.3 Percentage jongeren (15-29 jaar) en ouderen (50-64 jaar) per bedrijfssector, gemiddelde 1994-1995

1.4 Percentage allochtonen per bedrijfssector, gemiddelde 1994-1995

1.5 Percentage werkenden naar opleidingsniveau per bedrijfssector, gemiddelde 1994-1995

1.6 Deeltijdarbeid per bedrijfssector, gemiddelde 1994-1995

1.7 Zelfstandigen per bedrijfssector, gemiddelde 1994-1995

1.8 Flexibel werk per bedriffssector, gemiddelde 1994-1995

1.9 Percentage werknemers met vast werk per bedrijfssector, gemiddelde 1994-1995

1.10 Belangrijkste beroepsklassen per bedrijfssector, gemiddelde 1994-1995 7

1.11 Belangrijkste opleidingstypen per bedrijfssector, gemiddelde 1994-1995

1.12 Conjunctuurgevoeligheid per bedrijfssector

1.13 Verwachte uitbreidingsvraag per bedrijfssector, 1995-2000

\section{INFORMATIE OVER BEROEPEN}

\section{Figuren}

2.1 Verwachte baanopeningen verdeeld naar uitbreidings- en vervangingsvraag per beroepssector, 1995-2000

Tabellen

2.1 Aantal werkenden per beroepsklasse, gemiddelde 1994-1995 18

2.2 Percentage vrouwen per beroepsklasse, gemiddelde 1994-1995 21

2.3 Percentage jongeren (15-29 jaar) en ouderen (50-64 jaar) per
beroepskiasse, gemiddelde 1994-1995

2.4 Percentage allochtonen per beroepsklasse, gemiddelde 1994-1995 29

Percentage werkenden naar opleidingsniveau per beroepsklasse,
gemiddelde 1994-1995

2.6 Deeltijdarbeid per beroepsklasse, gemiddelde 1994-1995 37

$2.7 \quad$ Zelfstandigen per beroepsklasse, gemiddelde 1994-1995 40

2.8 Belangrijkste bedrijfssectoren per beroepsklasse, gemiddelde 1994-1995 43

2.9 Uitwijkmogelijkheden naar verschillende bedrijfsklassen per beroepsklasse, gemiddelde 1994-1995 
2.10 Belangrijkste opleidingstypen per beroepsklasse, gemiddelde 1994-1995

2.11 Substitutiemogelijkheden tussen mensen met uiteenlopende opleidingsachtergronden per beroepsklasse, gemiddelde 1994-1995 73

2.12 Conjunctuurgevoeligheid per beroepsklasse

2.13 Verwachte uitbreidingsvraag per beroepsklasse, 1995-2000 79

2.14 Verwachte vervangingsvraag per beroepsklasse, 1995-2000 82

2.15 Verwachte baanopeningen per beroepsklasse, 1995-2000 85

\section{INFORMATIE OVER OPLEIDINGEN}

\section{Figuren}

3.1 Verwachte baanopeningen verdeeld naar uitbreidings- en vervangingsvraag per opleidingscategorie, $1995-2000$

3.2 Verwachte instroom van schoolverlaters per opleidingscategorie, 1995-2000

3.3 Arbeidsmarktperspectieven voor schoolverlaters per opleidingscategorie in 2000

Tabellen

3.1 Participatie schoolverlaters in vervolgopleidingen per opleidingsrichting, 199595

32

Aantal werkenden per opleidingstype, gemiddelde 1994-1995

3.3 Percentage vrouwen per opleidingstype, gemiddelde 1994-1995

3.4 Percentage vrouwelijke werkzame schoolverlaters per opleidingsrichting, 1995

3.5 Percentage jongeren (15-29 jaar) en ouderen (50-64 jaar) per opleidingstype, gemiddelde 1994-1995

3.6 Percentage allochtonen per opleidingstype, gemiddelde 1994-1995

3.7 Percentage allochtone werkzame schoolverlaters per opleidingsrichting, 1995

3.8 Deeltijdarbeid per opleidingstype, gemiddelde 1994-1995 114

3.9 Deeltijdarbeid onder werkzame schoolverlaters per opleidingsrichting, 1995116

3.10 Zelfstandigen per opleidingstype, gemiddelde 1994-1995 119

3.11 Flexibel werk per opleidingstype, gemiddelde 1994-1995 121

3.12 Percentage werknemers met vast werk per opleidingstype, gemiddelde 1994-1995

3.13 Percentage werkzame schoolverlaters met een vast dienstverband per opleidingsrichting, 1995

3.14 Gemiddeld bruto maandloon van werkzame schoolverlaters per opleidingsrichting, 1995

3.15 Belangrijkste beroepsklassen per opleidingstype, gemiddelde 1994-1995

3.16 Uitwijkmogelijkheden naar verschillende beroepsgroepen op een aansluitend of hoger functieniveau per opleidingstype, gemiddelde 1994-1995

3.17 Belangrijkste bedrijfssectoren per opleidingstype, gemiddelde 1994-1995

3.18 Uitwijkmogelijkheden naar verschillende bedrijfsklassen per opleidingstype, gemiddelde 1994-1995

Overzicht van opleidingstypen waarvan op de arbeidsmarkt (sterke) concurrentie wordt ondervonden

3.21 Percentage schoolverlaters met een intredewerkloosheid van 4 maanden of langer per opleidingsrichting, 1995

Percentage schoolverlaters dat als werkloos staat geregistreerd per opleidingsrichting, 1995 
3.23 Percentage onderbenutting per opleidingstype, 1995

3.24 Onderbenutting van werkzame schoolverlaters per opleidingsrichting, $1995 \quad 184$

3.25 Percentage werkzame schoolverlaters met een functie in de eigen vakrichting per opleidingsrichting, 1995

3.26 Verwachte instroom van schoolverlaters per opleidingstype, 1995-2000 190

3.27 Verwachte uitbreidingsvraag per opleidingstype, 1995-2000 192

3.28 Verwachte vervangingsvraag per opleidingstype, 1995-2000 194

3.29 Verwachte baanopeningen per opleidingstype, 1995-2000 196

3.30 Indicator toekomstige arbeidsmarktsituatie (ITA) en Indicator toekomstige kans op knelpunten in de personeelsvoorziening (ITKP) naar opleidingstype in 2000

Bijlage A

A.1 Bedrijfssectoren op basis van SBI'78

A.2 Bedrijfssectoren op basis van SBI'93 



\section{Voorwoord}

Deze Actualisering van de Statistische Bijlage bij het in 1995 verschenen rapport De arbeidsmarkt naar opleiding en beroep tot 2000 (ROA-R-1995/3) geeft een systematisch overzicht van de verwachte arbeidsmarktontwikkelingen en de actualisatie van de actuele arbeidsmarktgegevens die ten grondslag liggen aan het hoofdrapport. Er wordt vanuit het Informatiesysteem Onderwijs-Arbeidsmarkt van het ROA - over de volle breedte van de arbeidsmarkt - informatie gegeven, verbijzonderd naar 13 bedrijfssectoren, 93 beroepsklassen en 79 opleidingstypen. De opleidingeninformatie is aangevuld met meer specifieke arbeidsmarktinformatie over de schoolverlaters van het AVO, VBO, MBO en HBO. De actuele arbeidsmarktgegevens zijn aangepast aan de in 1996 beschikbare informatie. In deze tussentijdse actualisering van de Statistische Bijlage zullen geen nieuwe prognoses en nieuwe informatie over de conjunctuurgevoeligheid van de werkgelegenheid worden gepresenteerd. Nieuwe arbeidsmarktprognoses, die betrekking zullen hebben op de vraag- en aanbodontwikkelingen op de arbeidsmarkt tot het jaar 2002, zullen najaar 1997 weer worden gepresenteerd in de nieuwe versie van het tweejaarlijkse rapport De arbeidsmarkt naar opleiding en beroep, met de bijbehorende Statistische Bijlage.

Deze Actualisering heeft dezelfde opbouw als de oorspronkelijke Statistische Bijlage bij De arbeidsmarkt naar opleiding en beroep tot 2000. Daarbij is ook de tabelnummering ongewijzigd gebleven. In deze Actualisering van de Statistische Bijlage 1995 wordt voor het eerst een beschrijving gegeven van de actuele ontwikkelingen op de arbeidsmarkt met betrekking tot de thema's die in de Statistische Bijlage per bedrijfssector, beroepsklasse en/of opleidingstype worden gepresenteerd. Deze beschrijving is gebaseerd op een vergelijking van de actuele arbeidsmarktinformatie die betrekking heeft op het gemiddelde van de jaren 1994 en 1995 die in deze Statistische Bijlage wordt gepresenteerd, en de actuele arbeidsmarktinformatie die betrekking heeft op het gemiddelde van de jaren 1993 en 1994 die in de oorspronkelijke Statistische Bijlage is terug te vinden. Deze vergelijking heeft tot doel om gemakkelijker inzicht te geven in de verschuivingen die zich in de tussenliggende periode op de arbeidsmarkt hebben voorgedaan.

Het hoofdrapport De arbeidsmarkt naar opleiding en beroep tot 2000 geeft het kader aan waarin de tabellen in deze Statistische Bijlage moeten worden geplaatst. Om echter ook voor bij zelfstandig gebruik van deze publicatie de betekenis van de geboden informatie aan te geven is verder een korte toelichting bij het gebruik opgenomen.

Deze Statistische Bijlage bestaat evenals vorig jaar uit drie delen, die betrekking hebben op de arbeidsmarktinformatie naar bedrijfssector, beroep en opleiding. In deze drie delen wordt achtereenvolgens arbeidsmarktinformatie gepresenteerd met betrekking tot de persoonskenmerken van de werkenden, de functiekenmerken, de substitutiemogelijkheden op de arbeidsmarkt en de conjunctuurgevoeligheid van de werkgelegenheid en de voor de periode 1995-2000 verwachte arbeidsmarktontwikkelingen. In aanvulling hierop wordt bij de opleidingen informatie gepresenteerd met betrekking tot de huidige en de 
toekomstige aansluitingsproblemen op de arbeidsmarkt. Tevens wordt de opleidingeninformatie op een aantal punten aangevuld met actuele schoolverlatersinformatie.

In de meeste tabellen wordt ook een kwalitatieve typering gegeven van de gepresenteerde informatie. Bij de actuele arbeidsmarktinformatie wordt tevens een indicatie gegeven van de trend in de afgelopen jaren. Bij de informatie over beroepen gaat het hierbij in principe om de ontwikkeling in de periode 1991-1995. Door het ontbreken van de benodigde informatie over de eerste jaren van deze periode, is er bij de opleidingen en bij enkele specifieke arbeidsmarktgegevens echter slechts gekeken naar de trendmatige ontwikkeling in de jaren 1993-1995. Doordat er slechts voor twee jaar informatie beschikbaar is over bedrijven volgens de Standaard Bedrijfsindeling 1993 (SB|'93) is voor de informatie met betrekking tot bedrijven slechts gekeken naar de trendmatige ontwikkeling in de jaren 1994-1995. De informatie over de trendmatige ontwikkeling heeft meestal betrekking op de ontwikkeling van het aandeel van de desbetreffende categorie. Alleen bij de tabellen 1.1, 2.1 en 3.2 gaat het om de ontwikkeling van het aantal werkenden.

De arbeidsmarktgegevens met betrekking tot de werkzame bevolking zijn afkomstig uit de Enquete Beroepsbevolking (EBB) van het Centraal Bureau voor de Statistiek (CBS). Om de robuustheid van de informatie te vergroten, hebben de gepresenteerde gegevens telkens betrekking op het gemiddelde van de jaren 1994 en 1995. Om de herkenbaarheid van individuele respondenten te voorkomen, heeft het CBS de restrictie gesteld dat bij het publiceren van tweejaarlijkse gemiddelden alleen cijfers over categorieën mogen worden gepresenteerd die betrekking hebben op minimaal 2.500 personen.

In de EBB 1995 is geen informatie meer beschikbaar over bedrijven gecodeerd volgens de Standaard Bedrijfsindeling 1978 (SBI'78). De SBI78 werd tot nu toe gebruikt voor het indelen van bedrijven naar bedrijfssectoren. Door het ontbreken van deze gegevens is de overstap gemaakt naar een indeling volgens de SBI'93, waarvan momenteel zoals reeds eerder is opgemerkt nog slechts voor twee jaar informatie beschikbaar is (EBB 1994 en 1995). Door deze overstap wijkt de gehanteerde bedrijfssectorindeling enigszins af van die in de vorige Statistische Bijlage. Dit is met name van invloed op de volgende bedrijfssectoren: Overheid, Overige comerciële dienstverlening, Overige industrie (waar de meubelindustrie vervalt en gaat naar de sector Metaal en elektrotechniek) en in mindere mate de Bouw. De actuele informatie over bedrijven is gebaseerd op de SBI'93, terwijl de niet geactualiseerde informatie over conjunctuurgevoeligheid en de prognoses per bedrijfssector nog gebaseerd zijn op de (oude) SBI78. De gehanteerde indelingen zijn in Bijlage A opgenomen.

In deze Actualisering van de Statistische Bijlage zijn de verdeeltabellen (tabellen 1.10,

1. De wijze waarop deze typeringen en trendmatige ontwikkelingen zijn bepaald, wordt beschreven in het werkdocument Methodiek van het informatiesysteem onderwijs-arbeidsmarkt 1995, ROA-W-1995/3, Maastricht, 1995. 
$1.11,2.8,2.10,3.15$ en 3.17 ), die een overzicht geven van bijvoorbeeld de belangrijkste opleidingstypen per bedrijfssector, uitvoeriger dan in de vorige Statistische Bijlage. In de vorige Statistische Bijlage worden alleen de categorieën gepresenteerd die voorkomen in een bepaalde beroepsklasse, bedrijfssector of opleidingstype met meer dan 2.500 werkenden én een werkgelegenheidsaandeel van $5 \%$ of meer. In deze actualisering worden alle opleidingstypen, beroepsklassen of bedrijfssectoren gepresenteerd die meer dan 2.500 werkenden hebben én een werkgelegenheidsaandeel van $3 \%$ of meer. Hierdoor wordt de informatie met betrekking tot de kleinere opleidingstypen, beroepsklassen of bedrijfssectoren aanmerkelijk vergroot. Eveneens wordt ditmaal in deze tabellen het resterende percentage aangegeven van de beroepsklassen, bedrijfssectoren of opleidingstypen die niet gepresenteerd worden. Nog uitgebreidere versies van deze tabellen, waarbij alle werkgelegenheidsaandelen van minstens 2.500 zijn opgenomen, zijn vanwege hun omvang niet opgenomen in deze Statistische Bijlage. Omdat dergelijke gedetailleerde informatie voor een aantal betrokkenen van belang kan zijn, zijn ze opgenomen in een aparte uitgave ${ }^{2}$ die bij het ROA verkregen kan worden.

De in het derde deel gepresenteerde schoolverlatersinformatie is afkomstig uit de grootschalige schoolverlatersenquêtes Registratie Uitstroom en Bestemming van Schoolverlaters (RUBS) en de HBO-Monitor ${ }^{3}$. In deze onderzoeken worden de schoolverlaters respectievelijk driekwart en anderhalf jaar na het verlaten van de opleiding geënquêteerd. De in deze geactualiseerde versie van de Statistische Bijlage gepresenteerde informatie heeft betrekking op de arbeidsmarktsituatie in 1995 van de gediplomeerden uit het leerjaar 1993-1994. Aan het presenteren van deze schoolverlatersinformatie is de restrictie gesteld dat de gepubliceerde informatie per categorie minimaal betrekking moet hebben op 25 respondenten.

Er zijn geen schoolverlatergegevens bekend voor het basisonderwijs en het WO. Door het ontbreken van informatie over enkele opleidingstypen in de schoolverlatersenquête RUBS 1995, kunnen verder in deze Statistische Bijlage geen schoolverlatersgegevens worden gepresenteerd over. VBO installatietechniek, KMLO (Kort Middelbaar Laboratorium Onderwijs), KMBO metaalbewerking, MBO procestechniek en MBO medisch laboratorium. Daarentegen wordt in tegenstelling tot de oorspronkelijke Statistische Bijlage wel schoolverlatersinformatie gegeven over de opleidingsrichting MBO toerisme. Eveneens zijn er ten opzichte van de vorige Statistische Bijlage een aantal verouderde opleidingsnamen met betrekking tot de schoolverlatersinformatie geactualiseerd. Voor het agrarische onderwijs op MBO-niveau is een nieuwe indeling gehanteerd die meer opleidingsrichtingen onderscheidt. Het gaat hierbij om de volgende veranderingen:

2. Verdeeltabellen van bedrijfssectoren, beroepsklassen en opleidingstypen.

3. De opleidingsindeling die gehanteerd wordt voor de HBO-opleidingsrichtingen is afwijkend van de tabellen in de publicaties van de HBO-Monitor. De schoolverlatersinformatie over met name de opleidingsrichting HBO leraar agrarisch wijkt op enkele punten af van de informatie in de rapportage van de HBO-Monitor. 
VBO metaalkunde

VBO kantoorpraktijk

VBO verkooppraktijk

MBO metaalkunde

MBO civ. en cons. technische diensten

MAS A en $B$ land- en tuinbouw

\author{
VBO mechanische techniek \\ VBO administratie \\ VBO verkoop en handel \\ MBO mechanische techniek \\ MBO facilitaire dienstverlening \\ MBO plantenteelt, MBO veehouderij, \\ MBO levensmiddelentechnologie, \\ MBO dierenverzorging, MBO groene ruimte
}

Verder zijn een aantal namen van beroepsklassen aangepast aan de nieuwe spelling.

In de tabellen met arbeidsmarktgegevens worden de volgende tekens gebruikt:

. er wordt niet voldaan aan de ondergrens voor publicatie.

- typering of trend is onbekend.

Achterin het hoofdrapport worden de gehanteerde centrale begrippen gedefinieerd, waarbij telkens verwezen wordt naar de publicaties waarin nadere informatie te vinden is. In Bijlage A van de Statistische Bijlage wordt een overzicht gegeven van de onderscheiden bedrijfssectoren, beroepsklassen en opleidingstypen met bijbehorende coderingen.

Deze geactualiseerde Statistische Bijlage is samengesteld door drs. A.G.M. Matheeuwsen. De projectleiding van het ROA-informatiesysteem - waarover de Statistische Bijlage rapporteert - is in handen van dr. A. de Grip en dr. L. Borghans. Aan de huidige versie van het informatiesysteem is ook meegewerkt door drs. R.J.P. Dekker, prof.dr. J.A.M. Heijke, drs. J. Hoevenberg, drs. W. Smits en drs. E.J.T.A. Willems.

Onze dank gaat uit naar de leden van de begeleidingscommissie Deze commissie bestaat uit de volgende leden: prof.dr. J.L. Peschar (voorzitter, Rijksuniversiteit Groningen), drs. J.W. Altena (Centraal Bureau voor de Statistiek), drs. J. Lint (Ministerie van Landbouw, Natuurbeheer en Visserij), dhr. H. Daale (Noordelijke Hogeschool Leeuwarden), drs. J. Fokkema (Landelijk Bureau voor de Arbeidsvoorziening), drs. C. Gorter (Ministerie Economische Zaken), drs. E. Janissen (LDC), drs. H.J. Roodenburg (Centraal Planbureau), drs. J.J. Smit (Ministerie van Sociale Zaken en Werkgelegenheid), drs. M. Wegerif (Landelijk Bureau voor de Arbeidsvoorziening), drs. G.R. de Wit (LDC), drs. B.T.M. Verlaan (Ministerie van Onderwijs, Cultuur en Wetenschappen) en drs. J.P. Vosse (Organisatie voor Strategisch Arbeidsmarktonderzoek). 


\section{Toelichting bij het gebruik}

In deze Statistische Bijlage bij de Arbeidsmarkt naar opleiding en beroep tot 2000 is informatie bijeengebracht die een beeld geeft van de arbeidsmarktsituatie van achtereenvolgens bedrijfssectoren, beroepsklassen en opleidingstypen. Deze gegevens hebben tot doel de aansluiting tussen onderwijs en arbeidsmarkt transparant te maken. Dit kan een ondersteuning betekenen voor degenen die betrokken zijn bij beslissingen rondom het onderwijs. Hierbij kan gedacht worden aan leerlingen die voor hun studiekeuze staan, de overheid, de arbeidsvoorzieningsorganisatie, scholen en ook personen die in het bedrijfsleven betrokken zijn bij het wervingsbeleid.

Om inzicht te geven in de aansluiting tussen onderwijs en arbeidsmarkt wordt een drietal groepen gegevens gepresenteerd. Dit zijn de prognoses tot het jaar 2000, de actuele arbeidsmarktsituatie en de structurele positie van beroepen en opleidingen.

De prognoses hebben betrekking op de middellange termijn, in dit rapport tot het jaar 2000. Omdat veel (beroeps)opleidingen in Nederland een duur hebben van vier jaar is het van belang om te anticiperen op de ontwikkelingen op de arbeidsmarkt over vijf jaar. Hierdoor kan een eventuele omslag in de arbeidsmarktpositie tijdig worden voorzien. De prognoses zijn opgesteld uit een vergelijking van vraag en aanbod van nieuwkomers op de arbeidsmarkt. Aan de vraagkant betreft dit de uitbreidingsvraag en de vervangingsvraag die tezamen de baanopeningen vormen. Aan de aanbodkant gaat het in de eerste plaats om de arbeidsmarktintroom van schoolverlaters. De Indicator Toekomstige Arbeidsmarktsituatie (ITA) geeft de verhouding tussen vraag en aanbod weer. Hierbij is tevens rekening gehouden met het aanbod van kortdurige werklozen en zijn ook de effecten verdisconteerd die het gevolg zijn vraagoverschotten of -tekorten bij naburige opleidingstypen. ${ }^{4}$ Daarbij moet worden bedacht dat een aanbodoverschot van mensen met een bepaalde opleidingsachtergrond niet per se tot werkloosheid van de betrokkenen hoeft te leiden. Veelal uiten discrepanties tussen vraag en aanbod zich in een hogere kans op werk buiten het eigen vakgebied, of beneden het gevolgde opleidingsniveau, een lagere beloning, meer kans op een tijdelijk contract, enz.

Bij de actuele arbeidsmarktinformatie wordt tevens een indicatie van de trend gegeven. Deze trend weerspiegelt de veranderingen in de betreffende grootheid in de afgelopen periode en heeft op zich geen voorspellende betekenis. Hoewel de actuele situatie af kan wijken van de ontwikkelingen tot 2000 is het van belang de voorspelde arbeidsmarktperspectieven te bezien in het licht van de actuele arbeidsmarktsituatie. Met name tussen de verschillende opleidingsniveaus bestaan er immers aanzienlijke meer structurele verschillen in de arbeidsmarktpositie die door tegengestelde arbeidsmarktperspectieven niet geheel zullen worden weggenomen. Zo zal een WO-afgestudeerde die een richting volgt

4. In De arbeidsmarkt naar opleiding en beroep tot 2000 wordt in figuur 2.1 de globale opzet van het prognosemodel in beeld gebracht. 
met slechte perspectieven mogelijk een functie krijgen met een minder gunstige beloning, maar dan toch kan deze beloning hoger liggen dan van VBO'ers uit richtingen met een gunstig perspectief.

Om deze reden wordt naast de prognoses informatie verstrekt over de actuele situatie op de arbeidsmarkt. Deze 'monitoring' - die deels is gebaseerd op enquêtes onder schoolverlaters - brengt daamaast kenmerken aan het licht die niet rechtstreeks gekoppeld kunnen worden aan het arbeidsmarktperspectief en wellicht door verschillende betrokkenen anders zullen worden gewaardeerd. Voorbeelden hiervan zijn de beroepenverdeling van de werkenden met een bepaalde opleidingsachtergrond, maar ook het percentage deeltijdwerk, dat voor de ene gunstig en door de ander juist als ongunstig zal worden beschouwd.

Als derde categorie is informatie opgenomen over de structurele positie van beroepsklassen en opleidingstypen. Het betreft hier de conjunctuurgevoeligheid van de werkgelegenheid, de uitwijk- en substitutiemogelijkheden en de concurrentie-index. Deze indicatoren hebben tot doel het geschetste perspectief in een breder kader te plaatsen. De prognoses van vraag en aanbod zijn uiteraard altijd aan onzekerheid onderhevig en verder zal een schoolverlater doorgaans een lange tijd op de arbeidsmarkt vertoeven. De structurele kenmerken beogen daarom een indicatie te geven van de het risico dat men op de arbeidsmarkt loopt. De conjunctuurgevoeligheid geeft aan in welke mate de werkgelegenheid in het betreffende segment aan schommelingen onderhevig is, terwijl de uitwijkmogelijkheden aangeven in welke mate werkenden afhankelijk zijn van de werkgelegenheidsontwikkelingen in één beroep of bedrijfssector of juist uit kunnen wijken naar meerdere beroepen en bedrijfssectoren. Verder geeft de concurrentie-index aan welke opleidingstypen een overlappend deel van de arbeidsmarkt bestrijken. Hierdoor ontstaat een beeld van de concurrerende opleidingstypen.

Zoals reeds is opgemerkt bevat de Statistische bijlage informatie over bedrijfssectoren, beroepsklassen en opleidingstypen. De confrontatie tussen vraag en aanbod vindt plaats op het niveau van opleidingstypen, omdat in eerste instantie de opleidingsachtergrond van werkenden de afbakening van deelmarkten op de arbeidsmarkt bepaalt. De prognoses met betrekking tot de onderscheiden bedrijfssectoren en beroepsklassen hebben daarom alleen betrekking op de vraagkant van de arbeidsmarkt. Men dient zich daarbij te realiseren dat een groot aantal baanopeningen niet altijd een gunstig perspectief hoeft in te houden, omdat ook in dat geval de aanbodontwikkeling nog omvangrijker kan zijn. 


\section{Ontwikkelingen op de arbeidsmarkt}

In de Statistische Bijlage die in 1995 is verschenen, wordt actuele arbeidsmarktinformatie met betrekking tot de werkzame bevolking gepresenteerd die gebaseerd is op de gemiddelde cijfers over 1993 en 1994. In deze actualisering heeft deze arbeidsmarktinformatie betrekking op de gemiddelde cijfers over 1994 en 1995. De gepresenteerde schoolverlatersinformatie in de vorige versie van de Statistische Bijlage heeft betrekking op de arbeidsmarktsituatie in 1994 van gediplomeerden uit het leerjaar 1992-1993, terwijl in deze Statistische Bijlage de arbeidsmarktsituatie in 1995 van de gediplomeerden uit het leerjaar 1993-1994 wordt gepubliceerd. De ontwikkelingen op de arbeidsmarkt die hier worden beschreven hebben tot doel de verschuivingen in kaart te brengen die zich in de tussenliggende periode hebben voorgedaan. Het gaat hierbij om een pure beschrijving van het cijfermateriaal, waarbij in principe niet op de achterliggende oorzaken wordt ingegaan. Hoewel het telkens gaat om relatief geringe verschuivingen, is het opvallend dat op enkele punten de arbeidsmarktsituatie voor schoolverlaters zich in tegengestelde richting ontwikkelt vergeleken met die van de gehele werkzame bevolking. Dit betreft bijvoorbeeld het percentage deeltijdwerkers, vast werk en onderbenutting. Daarbij is er telkens sprake van een verbetering van de arbeidsmarktpositie bij de schoolverlaters, tegenover veelal een verslechtering van de arbeidsmarktpositie van de gehele werkzame bevolking.

Hierna worden achtereenvolgens de ontwikkelingen op de arbeidsmarkt besproken met betrekking tot de persoonskenmerken van de werkenden, de functiekenmerken en de substitutiemogelijkheden op de arbeidsmarkt. Bij de informatie over bedrijfssectoren heeft, zoals in het voorwoord reeds is opgemerkt, een aanzienlijke verandering van de classificatie plaatsgevonden ${ }^{5}$. De ontwikkelingen op de arbeidsmarkt met betrekking tot bedrijfssectoren worden wel geanalyseerd, maar hierbij moet steeds rekening worden gehouden met de (niet geringe) invloed van deze overgang.

\section{Aantal werkenden}

De werkgelegenheid in personen is in Nederland met $1,4 \%$ toegenomen, van gemiddeld 5.885.500 werkenden in 1993/1994 tot gemiddeld 5.970.000 werkenden in 1994/1995.

De werkgelegenheid is voor bijna alle bedrijfssectoren toegenomen. Aangenomen mag echter worden dat de grote verschuivingen in de sectorale werkgelegenheidsstructuur voor een belangrijk deel zijn toe te schrijven aan de overgang van de SBI78 naar de SBI'93. Alleen bij van de sectoren landbouw en visserij en overige industrie is sprake van een krimpende werkgelegenheid. Voor de overheid en overige commerciële dienstveriening is de groei, zowel in absolute als in relatieve zin erg groot.

5. De arbeidsmarktinformatie over bedrijven is in deze Statistische Bijlage gebaseerd op een indeling die gebaseerd is op de SBI'93, terwijl de bedrijfsindeling voorheen gebaseerd was op de SBI'78. 
Voor iets meer dan de helft van de 93 beroepsklassen is de werkgelegenheid toegenomen. De werkgelegenheidsgroei is in absolute zin het grootst voor de beroepsklassen hogere leidinggevenden financiën, verkoop e.d. en chauffeurs en spoorwegpersoneel, met een groei van respectievelijk 12.500 en 10.000 werkenden. In relatieve zin is de werkgelegenheidsgroei het grootst voor de beroepsklassen monteurs en controleurs elektrotechnische producten en sportdocenten en -instructeurs. Het aantal monteurs en controleurs elektrotechnische producten neemt toe met bijna 25\%. De werkgelegenheid in de beroepsklasse sportdocenten en -instructeurs groeit met ongeveer $17 \%$. De economischeadministratieve beroepen commercieel-administratieve employés en administrateurs en bankemployés blijven de grootste beroepsklassen ondanks een lichte daling in de werkgelegenheid. In deze beroepsklassen zijn respectievelijk 357.000 en 351.000 mensen werkzaam. Met name bij veel technische, ambachts- en industrieberoepen is de werkgelegenheid dalend. In absolute zin is de werkgelegenheidskrimp het grootst voor de beroepsklassen monteurs en controleurs elektrotechnische installaties, machinebank-, plaatwerkers en smeden en economen en accountants, met alle een krimp van circa 5.000 werkenden. De werkgelegenheidskrimp is, in relatieve zin het grootst voor elektrotechnische constructeurs en ingenieurs en operators en datatypisten, met een krimp van ruim $20 \%$.

Voor 50 van de 79 opleidingstypen is de werkgelegenheid gegroeid. De werkgelegenheidsgroei is, in absolute zin het grootst voor de opleidingstypen $M B O / L W$ verpleging en medische assistentie en HAVONWO, met een groei van respectievelijk 13.000 en 11.500 werkenden. In relatieve zin is de werkgelegenheidsgroei het grootst voor de opleidingstypen WO kunst en HBO tolk en vertaler. Een daling in de werkgelegenheid doet zich met name voor bij personen met alleen basisonderwijs of een opleiding op VBO-niveau. In absolute zin is de werkgelegenheidsdaling het grootst voor de opleidingstypen basisonderwijs en VBO mechanische techniek. De werkgelegenheid voor deze opleidingstypen daalde met respectievelijk 12.500 en 10.000 werkenden. Ondanks deze werkgelegenheidsdaling blijt het basisonderwijs het grootste opleidingstype met bijna 500.000 werkenden.

Opvallend genoeg verandert de typering van de trend van dalend in constant, hetgeen erop lijkt te wijzen dat de krimp van de werkgelegenheid voor ongeschoolden is afgeremd. Bij de opleidingen op VBO- en MBO-niveau is de trend in het aantal werkenden overwegend dalend, terwijl de werkgelegenheid voor personen met een HBO- of WO-opleiding overwegend een stijgende trend vertoont.

Aandeel vrouwen in de werkgelegenheid

De verhouding tussen het aantal werkende mannen en vrouwen is ongewijzigd gebleven. Het werkgelegenheidsaandeel van vrouwen is $37 \%$, hetgeen overeenkomt met circa 2.210 .000 werkende vrouwen. 
Het werkgelegenheidsaandeel van vrouwen in de verschillende bedrijfssectoren blijft eveneens nagenoeg gelijk. In de bedrijfssectoren overheid, landbouw en visserij, overige industrie en bank- en verzekeringswezen neemt het percentage vrouwen in de werkgelegenheid licht af, terwijl in de sectoren voedings- en genotmiddelenindustrie en kwartaire diensten het percentage vrouwen iets toeneemt. Kwartaire diensten blijft de sector met het grootste werkgelegenheidsaandeel van vrouwen: $70 \%$. Daarentegen blijft het percentage vrouwen het kleinst in de bouw.

Het werkgelegenheidsaandeel van vrouwen neemt in absolute zin het sterkst af in de beroepsklassen taalkundigen, tolken en vertalers en bibliotheek- en archiefmedewerkers, met respectievelijk 8 en 5\%-punt. De beroepsklassen chauffeurs en spoorwegpersoneel en taalkundigen, tolken en vertalers vertonen in relatieve zin de sterkste afname, met een daling van circa $15 \%$. Daarentegen neemt het werkgelegenheidsaandeel van vrouwen in absolute zin het sterkst toe in de beroepsklassen fotografen, ontwerpers en vormgevers, chemo-technici en laboranten, paramedische en verwante functies, hogere leidinggevenden financiën, verkoop e.d., advocaten, rechters en notarissen en politie en beveiligingspersoneel. Deze laatste beroepsklasse kent ook de grootste relatieve groei van het werkgelegenheidsaandeel van vrouwen. Bij het politie en beveilingspersoneel groeit het werkgelegenheidsaandeel met ruim een kwart. In het algemeen is het werkgelegenheidsaandeel van vrouwen erg laag in de technische, ambachts- en industrieberoepen. Een uitzondering hierbij is de beroepsklasse patroonmakers, naaiers en zeilmakers, met een werkgelegenheidsaandeel van vrouwen van $75 \%$. Het percentage vrouwen is in het algemeen het grootst bij de medische en paramedische beroepen, met zelfs vrijwel alleen maar vrouwelijke werkenden in de beroepsklasse dokters-, tandarts- en dierenartsassistenten. Veranderingen in de typering van de trendmatige ontwikkeling hebben met name betrekking op een minder sterke groei of een sterkere afname van het percentage vrouwen in een bepaalde beroepsklasse.

Bijna de helft van de opleidingstypen met meer dan 2.500 vrouwelijke werkenden, laat een toename van het werkgelegenheidsaandeel van vrouwen zien. Het werkgelegenheidsaandeel van vrouwen neemt zowel in absolute als in relatieve zin het sterkst toe bij werkenden met een opleidingsachtergrond WO landbouw en milieukunde. In absolute zin is de groei eveneens groot bij WO kunst en HBO verpleging en paramedisch. Het opleidingstype MBO politie en defensie is na WO landbouw en milieukunde het opleidingstype met relatief de sterkste groei van het percentage vrouwen. Het werkgelegenheidsaandeel van vrouwen daalt zowel in absolute als in relatieve zin het sterkst voor het opleidingstype WO bestuurijk. In absolute zin daalt het aandeel vrouwen eveneens sterk voor MBO textiel- en ledertechniek. Daarentegen daalt het aandeel relatief sterk bij het opleidingstype HBO commerciële economie. Het werkgelegenheidsaandeel van vrouwen blijft het grootst bij het opleidingstype $M B O / L W$ secretarieel: $97 \%$.

In tegenstelling tot het groeiende aandeel vrouwen in de totale werkzame bevolking bij een meerderheid van de opleidingstypen, neemt het aandeel werkende vrouwen bij de 
schoolverlaters bij een meerderheid van de opleidingen af. In absolute zin daalt het werkgelegenheidsaandeel van vrouwen het sterkst bij de schoolverlaters met een opleidingsachtergrond MBO chemisch laboratorium en MBO commerciële economie. Het percentage vrouwelijke schoolverlaters van de chemisch-laboratorium-opleidingen op MBO-niveau neemt zelfs met circa $25 \%$-punt af. De daling van het percentage vrouwelijke schoolverlaters is eveneens aanzienlijk bij commercieel-economisch-opgeleiden op MBOniveau. In relatieve zin daalt het aandeel vrouwelijke schoolverlaters het sterkst bij de opleiding HBO bedrijfsinformatica. Met uitzondering van de opleidingsrichting haven en vervoer neemt het percentage vrouwelijke schoolverlaters met een technische MBOopleiding af.

\section{Aandeel jongeren (15-29 jaar) en ouderen (50-64 jaar)}

Het aandeel van jongeren in de werkgelegenheid in Nederland is afgenomen van $30,5 \%$ tot $29,3 \%$. Daarentegen neemt het werkgelegenheidsaandeel van ouderen licht toe met $0,5 \%$-punt tot bijna $15 \%$. Met eveneens een toename van zowel het aandeel $30-39$ jarigen als 40-49-jarigen illustreert dit het vergrijzingsproces van de werkzame bevolking.

In vrijwel alle bedrijfssectoren, met uitzondering van de sectoren landbouw en visserij en energie, neemt het percentage jongeren af met 1 of $2 \%$-punt. Het percentage ouderen neemt daarentegen bij de helft van de bedrijfssectoren toe met ongeveer $1 \%$, terwijl het in de andere sectoren bij benadering even groot blijt. De sectoren handel en overige commerciële dienstvertening hebben een relatief jonge leeftijdsopbouw. In de sector landbouw en visserij werken relatief veel ouderen: $25 \%$.

Voor het overgrote deel van de beroepsklassen neemt het percentage jongeren af. De afname is, in absolute zin het grootst bij de beroepsklassen sportdocenten en -instructeurs, bouwkundige projectleiders en opticiens en apothekersassistenten. Het werkgelegenheidsaandeel van jongeren daalt in deze beroepsklassen met $7 \%$-punt. In relatieve zin is de afname van het aandeel jongeren het grootst bij bouwkundige projectleiders, hogere werktuigkundigen en sociale wetenschappers. Daarentegen neemt het werkgelegenheidsaandeel van jongeren in absolute en relatieve zin het sterkst toe in de beroepsklassen werktuigbouwkundigen en huishoudkundige voorlichters. Ook in relatieve zin neemt het werkgelegenheidsaandeel van jongeren in deze beroepsklassen sterk toe. Het percentage ouderen neemt in het overgrote deel van de beroepsklassen toe. In absolute en relatieve zin neemt het werkgelegenheidsaandeel van ouderen het sterkst toe in de beroepsklassen heftruckchauffeurs. Het percentage ouderen stijgt verhoudingsgewijs eveneens sterk in de beroepsklassen leerling verpleegkundigen, zieken- en kraamverzorgenden en productiepersoneel grafische industrie. In de beroepsklassen geestelijke verzorgers en beleidsmedewerkers en hoofdambtenaren neemt het werkgelegenheidsaandeel van ouderen in absolute zin het sterkst af. Het percentage ouderen neemt ook in relatieve zin het sterkst af bij de geestelijke verzorgers. De relatieve daling is eveneens groot in de beroepsklassen technisch tekenaars en politie en beveiligingspersoneel. De technische, 
ambachts- en industrieberoepen hebben een relatief jonge leeftijdsopbouw, evenals de medische en paramedische beroepen, maar hierbij is de beroepsklasse artsen, medische specialisten en apothekers een uitzondering. De pedagogische beroepen hebben daarentegen een relatief oudere leeftijdsopbouw, met uitzondering van de sportdocenten en -instructeurs.

De daling van het werkgelegenheidsaandeel van jongeren doet zich ook bij het overgrote deel van de opleidingstypen voor, terwijl het percentage ouderen bij de meeste opleidingstypen toeneemt. Het percentage jongeren daalt bij bijna alle opleidingen op VBO- en MBO-niveau. In absolute zin daalt het percentage jongeren het sterkst bij de opleidingstypen $M B O / \perp W$ verzorging en $H B O$ medisch laboratorium. Bij de opleidingen $H B O$ medisch laboratorium, MBO $L W$ fijnmechanische techniek en HBO technisch laboratorium is de daling van het werkgelegenheidsaandeel van jongeren relatief gezien het grootst. Daarentegen stijgt het werkgelegenheidsaandeel van jongeren in absolute zin het sterkst voor de opleidingstypen $H B O$ bestuurlijk-juridisch, $H B O$ haven en vervoer en $H B O$ bedrijfseconomie. Voor de eerstgenoemde twee opleidingstypen is ook de relatieve stijging van het werkgelegenheidsaandeel van jongeren het grootst. In absolute zin neemt het werkgelegenheidsaandeel van ouderen het sterkst toe in de opleidingstypen WO wiskunde en natuurwetenschappen, HBO werktuigbouwkunde en WO juridisch. Met uitzondering van $H B O$ werktuigbouwkunde zijn dit ook de opleidingstypen waarvoor in relatieve zin de toename van het percentage ouderen het grootst is. Ook voor de opleidingstypen MBO $L W$ secretarieel en VBO motorvoertuigentechniek neemt het aandeel ouderen relatief sterk toe.

\section{Allochtonen}

Het werkgelegenheidsaandeel van allochtone arbeidskrachten is gelijk gebleven, met een aandeel in de totale Nederlandse werkgelegenheid van circa $8 \%$. Het percentage allochtonen dat afkomstig is uit landen die genoemd zijn in de Wet Bevordering Evenredige Arbeidsdeeiname Allochtonen (WBEAA) ${ }^{6}$ blijt $3,3 \%$; het aantal werkenden is gegroeid met 8.000. Het percentage allochtonen dat niet onder deze wet valt is $4,8 \%^{7}$.

Ook in de meeste bedrijfssectoren is het werkgelegenheidsaandeel van allochtonen gelijk gebleven. Een uitzondering is de bedrijfssector overige industrie, waarbinnen het percentage allochtonen licht is gestegen. In de landbouw en visserij en de bouw is het laagste percentage allochtonen werkzaam: $2 \%$. Daarentegen is het werkgelegenheidsaandeel van allochtonen het grootst in de voedings- en genotmiddelenindustrie.

6. In de WBEAA worden overigens ook allochtonen van de tweede generatie - dat wil zeggen kinderen van ouders die in een van de betreffende landen zijn geboren of de nationaliteit van dit land hebben tot de doelgroep gerekend. Hier wordt de CBS-definitie gehanteerd die alleen de eerste generatie meetelt, tenzij men (nog) niet de Nederlandse nationaliteit heeft.

7. Hierna wordt steeds de term allochtonen gebruikt voor de allochtonen uit landen die vallen onder de WBEAA. 
Ook in bijna alle beroepsklassen is het werkgelegenheidsaandeel van allochtonen gelijk gebleven. Het werkgelegenheidsaandeel van allochtonen neemt echter af in de beroepsklassen metaalbewerkers, lassers, constructeurs en edelsmeden, voedings- en genotmiddelenbereiders, expeditie-medewerkers en politie en beveiligingspersoneel. Verhoudingsgewijs is de daling het grootst voor de metaalbewerkers en politie en beveilingspersoneel. Daarentegen neemt het werkgelegenheidsaandeel van allochtonen iets toe in de beroepsklassen productiepersoneel aardewerk- en glasindustrie, keuken- en serveerpersoneel, wegenbouwvakkrachten en buizenleggers, chauffeurs en spoorwegpersoneel en secretaresses en typisten. De relatieve stijging van het werkgelegenheidsaandeel van allochtonen is het grootst voor keuken- en serveerpersoneel en secretaresses en typistes, chauffeurs en spoorwegpersoneel. Het werkgelegenheidsaandeel van allochtonen is met name hoog bij de technische, ambachts- en industrieberoepen en verzorgende en dienstverlenende beroepen. De beroepsklasse productiepersoneel aardewerk- en glasindustrie is het hoogste percentage allochtonen werkzaam: $13 \%$. In het overgrote deel van de beroepsklassen zijn overigens minder dan 2.500 allochtonen werkzaam, waardoor er geen indruk is te geven van de ontwikkeling van hun werkgelegenheidsaandeel.

Als gekeken wordt naar de opleidingsachtergrond, zijn er vrijwel alleen bij de ongeschoolden en bij de opleidingstypen op VBO- en MBO-niveau meer dan 2.500 allochtonen werkzaam. Het percentage allochtonen blijft het grootst voor de ongeschoolden: $11 \%$. Het werkgelegenheidsaandeel van allochtonen stijgt licht voor de opleidingstypen VBO verzorging, MBO/LW verpleging en medische assistentie, HAVONWO bovenbouw en MAVO, onderbouw HAVONWO. Daarentegen is er een geringe daling van het werkgelegenheidsaandeel van allochtonen bij de opleidingstypen VBO elektrotechniek, VBO mechanische techniek en VBO administratie.

Het percentage allochtone werkzame schoolveriaters ligt bij de verschillende opleidingstypen tussen de 1 en $4 \%$. Het percentage allochtonen was in 1994 het grootst voor het opleidingstype VBO administratie. Het percentage allochtonen daalt in absolute zin bij dit opleidingstype echter het sterkst: 7\%-punt. In 1995 hebben de opleidingstypen MBO mechanische techniek en VBO elektrotechniek het hoogste percentage allochtone schoolverlaters, respectievelijk 19 en $16 \%$. Het percentage allochtonen daalt ook bij de werkzame schoolverlaters van de opleidingstypen MAVO, onderbouw HAVONWO, VBO verkoop en handel, MBO elektrotechniek, MBO administratie en MBO textiel- en ledertechniek. Het percentage allochtonen neemt toe bij een viertal KMBO-opleidingen: administratie, detailhandel, motorvoertuigentechniek en elektrotechniek.

\section{Opleidingsniveau}

Het opleidingsniveau van de werkenden is iets toegenomen. Het percentage werkzame personen met hoogstens basisonderwijs als opleidingsachtergrond is afgenomen van $8,6 \%$ tot $8,3 \%$. Het percentage VBO-opgeleiden is eveneens licht gedaald, terwijl het werkgelegenheidsaandeel van de MAVO'ers vrijwel stabiel gebleven is. Daarentegen zijn 
de aandelen van werkzame personen met een HAVONWO-, MBO-, HBO- of WOopleidingsachtergrond licht gestegen, waarbij de grootste toename zich voordoet bij de MBO-opgeleiden ( $\operatorname{van} 38,8$ tot $39,2 \%$ ), de HBO'ers ( $\operatorname{van} 17,0$ tot $17,2 \%$ ) en de WOopgeleiden ( $\operatorname{van} 7,5$ tot $7,8 \%$ ).

Dit beeld doet zich eveneens in verschillende bedrijfssectoren voor. Bij de overige industrie neemt het werkgelegenheidsaandeel van de MBO'ers echter niet toe. Bij het bank- en verzekeringswezen neemt het werkgelegenheidsaandeel van de MBO'ers zelfs af ten gunste van WO'ers en HAVOMWO'ers. De opleidingsstructuur van de werkgelegenheid bij de overheid blijt gelijk.

Bij verschillende beroepsklassen is er eveneens sprake van een verhoging van het opleidingsniveau. Daarbij is er sprake van een toename van het werkgelegenheidsaandeel van de HAVONWO'ers, MBO'ers, HBO'ers en WO'ers. Het gemiddelde opleidingsniveau neemt met name bij veel technische, ambachts- en industrieberoepen, pedagogische, culturele en transportberoepen toe.

\section{Onderbenutting}

Bij circa driekwart van de opleidingstypen is het percentage werkenden dat een functie bekleedt beneden hun opleidingsniveau toegenomen. De onderbenutting - die bepaald is op basis van de beoordeling van functies door beroependeskundigen - van werkenden met een opleidingsachtergrond $M B O$ toerisme en recreatie, MBO $L L W$ verzorging, $H B O$ tolk en vertaler en $H B O$ accountancy is het meest toegenomen. Daarentegen is de onderbenutting het meest afgenomen bij de opleidingstypen WO letteren, MBO $L W$ procestechniek, VBO installatietechniek en HBO toerisme en recreatie. De onderbenutting is het laagst bij de opleidingstypen WO dier-, genees- en tandheelkunde en $M B O / L W$ medisch laboratorium, terwijl de onderbenutting het hoogst is bij de opleiding VBO haven en vervoer. In het algemeen geldt dat met het toenemen van het opleidingsniveau ook de onderbenutting afneemt.

De onderbenutting van schoolverlaters - gemeten op basis van hun eigen oordeel - blijkt bij ongeveer evenveel opleidingen toe als af te nemen. De onderbenutting van schoolverlaters met als opleidingsachtergrond MAVO of een opleiding op VBO-niveau neemt in het algemeen toe. In relatieve zin neemt de onderbenutting van schoolverlaters het sterkst toe bij de opleiding VBO consumptieve techniek. De onderbenutting van schoolverlaters neemt het sterkst toe bij personen met een opleidingsachtergrond MBO textiel- en ledertechniek, MBO sociale arbeid, HBO haven en vervoer, VBO elektrotechniek, VBO land- en tuinbouw en MBO chemisch laboratorium. Daarentegen neemt de onderbenutting het meest af bij de opleidingen KMBO motorvoertuigentechniek, MBO assistent gezondheidszorg, MBO verpleging en ziekenverzorging, KMBO elektrotechniek en MBO horeca. De onderbenutting is het hoogst voor schoolverlaters met een opleidingsachtergrond $M B O$ facilitaire dienstverlening. Maar liefst $77 \%$ van de schoolverlaters met deze opleidingsach- 
tergrond werkt op een functieniveau beneden hun opleidingsniveau.

\section{Deeltijd}

Het percentage deeltijders - zoals in het gehele rapport gemeten in personen - is toegenomen met $1,2 \%$-punt van 24,6 tot $25,8 \%$. In de meeste bedrijfssectoren heeft zich een toename in deze orde van grootte voorgedaan. Een uitzondering is echter de bedrijfssector overige industrie, waarvoor het percentage in deeltijd werkenden licht is gedaald. Voor de kwartaire sector, die ook het hoogste percentage deeltijdwerkers heeft, is de toename van het percentage deeltijdwerkers het grootst. Relatief gezien stijgt het werkgelegenheidsaandeel van deeltijdwerkenden het sterkst in de bedrijfssectoren energie, voedings- en genotmiddelenindustrie, chemie en metaal en elektrotechniek.

Ook in het merendeel van de beroepsklassen neemt het percentage deeltijders toe. De stijging van het percentage deeltijders is het grootst bij de medische en paramedische beroepen analisten en laboranten, leerling-verpleegkundigen, zieken- en kraamverzorgenden, opticiens en apothekersassistenten en fysio-, arbeids- e.a. bewegingstherapeuten. In relatieve zin stijgt het werkgelegenheidsaandeel van deeltijders het sterkst in de beroepsklassen programmeurs en systeemanalisten, wegenbouwvakkrachten en buizenleggers, hogere leidinggevenden financiën, verkoop e.d. en leidinggevend administratief personeel. Het percentage deeltijdwerkenden blijt met $78 \%$ het hoogst bij de beroepsklasse kinder-, gezins- en bejaardenverzorgenden. In het algemeen werkt nagenoeg meer dan de helft van de werkenden in de medische en paramedische, de sociaal-culturele en de verzorgende en dienstverlendende beroepen in deeltijd. Er zijn echter ook een aantal beroepsklassen waarin het percentage deeltijdwerkers afneemt. De daling is het sterkst in de beroepsklassen bibliotheek- en archiefmedewerkers, taalkundigen, tolken en verlaters, monteurs en controleurs elektrotechnische installaties en artsen, medische specialisten en apothekers. In de technische, ambachts- en industrie-, transport- en openbare orde- en veiligheidsberoepen is in het algemeen slechts een erg laag aandeel van de arbeidskrachten in deeltijd werkzaam.

Verbijzonderd naar opleidingsachtergrond blijkt dat bij het overgrote deel van de opleidingstypen het percentage deeltijders gelijk blijft of toeneemt. Slechts een klein deel van de werkenden met een technische opleidingsachtergrond werkt in deeltijd, terwijl juist een hoog percentage van de personen met een economische, sociaal-culturele, verzorgende of algemene opleiding in deeltijd werkt. Arbeidskrachten met een opleidingsachtergrond op WO-niveau werken relatief minder in deeltijd. Het percentage deeltijders neemt het sterkst toe bij de opleidingstypen HBO tolk en vertaler, WO landbouw en milieukunde, MBO technisch laboratorium en MBOЛLW secretarieel. Het percentage deeltijdarbeid daalt het sterkst bij de opleidingen WO kunst en WO econom(etr)ie en accountancy.

In tegenstelling tot de ontwikkeling bij de beroepsbevolking in zijn geheel, neemt bij de werkzame schoolverlaters het percentage deeltijdwerkers voor meer opleidingstypen af 
dan toe. Voor schoolverlaters met een opleiding MAVO, VBO land- en tuinbouw, HBO agrarisch, VBO, MBO en HBO techniek en HBO economisch-administratief neemt het percentage deeltijders in het algemeen af. Daarentegen neemt in het algemeen het percentage schoolverlaters dat in deeltijd werkt toe bij de opleidingstypen VBO en MBO economisch-administratief, VBO en MBO verzorgend, MBO sociale arbeid, HBO onderwijs en $H B O$ tolk en verlater. De daling van het percentage in deeltijd werkende schoolverlaters is het grootst bij de opleidingen KMBO elektrotechniek, VBO elektrotechniek, KMBO detailhandel, VBO mechanische techniek en KMBO consumptieve techniek. Daarentegen is de stijging van het percentage deeltijders het sterkst bij de opleidingen VBO administratie, MBO handel en MBO horeca. Het percentage deeltijders stijgt in relatieve zin het sterkst bij $H B O$ accountancy. Het percentage deeltijders is het hoogst bij de opleiding VBO administratie: $78 \%$.

\section{Zelfstandigen}

Het werkgelegenheidsaandeel van de zelfstandigen is nagenoeg gelijk gebleven op een niveau van bijna $12 \%$.

De bedrijfssector landbouw en visserij heeft verreweg het grootste percentage zelfstandigen, gevolgd door overige commerciële dienstverlening, handel en de bouw. Het percentage zelfstandigen stijgt licht in de bedrijfssectoren voedings- en genotmiddelenindustrie, metaal en elektrotechniek, bouw, handel, bank- en verzekeringswezen en overheid. Daarentegen daalt het aandeel zelfstandigen in de landbouw en visserij en bij de overige industrie.

Het percentage zelfstandigen daalt het sterkst in de beroepskiassen uitvoerend agrarisch personeel, architecten en bouwkundige ingenieurs, patroonmakers, naaiers en zeilmakers en verkooppersoneel. Daarentegen stijgt het werkgelegenheidsaandeel van zelfstandigen het sterkst in de beroepsklassen taalkundigen, tolken en vertalers, kappers en schoonheidsspecialisten, schilders en leidinggevenden horeca. Het percentage zelfstandigen is relatief laag bij de pedagogische, technische, ambachts- en industrie-, economischadministratieve, sociaal-culturele en openbare orde- en veiligheidsberoepen. Hoewel de trend bij technische, ambachts- en industrie-, economisch-administratieve en sociaalculturele beroepen overwegend stijgend is. Daarentegen is het percentage zelfstandigen relatief hoog bij de agrarische, culturele en paramedische beroepen.

Bij de opleidingstypen stijgt het percentage zelfstandigen het sterkst bij $M B O / L W$ werktuigbouwkunde en MBO/LLW textiel- en ledertechniek. Het werkgelegenheidsaandeel van zelfstandigen daalt het sterkst bij de opleidingstypen WO en HBO (weg- en water)bouwkunde, VBO landbouw en natuurlijke omgeving en WO dier-, genees- en tandheelkunde. In het algemeen is het percentage zelfstandigen het laagst bij degenen met een opleidingsachtergrond op VBO-niveau. Bij het opleidingstype $M B O / L W$ landbouw en natuurlijke omgeving is het percentage zelfstandigen het hoogst: $46 \%$. 


\section{Flexibel werk}

Het percentage werkenden met een flexibel arbeidscontract is toegenomen van 6,9 tot $7,6 \%$ van de totale werkgelegenheid.

Vooral in de sector metaal en elektrotechniek is het percentage flexibele arbeidscontracten duidelijk toegenomen. In de voedings- en genotmiddelenindustrie, overige industrie, chemie, bouw, overige commerciële dienstverlening en kwartaire diensten is er eveneens sprake van een toename van het percentage flexibele arbeidsrelaties. In de overige bedrijfssectoren is het werkgelegenheidsaandeel van het flexibel werk gelijk gebleven.

Slechts bij drie opleidingstypen daalt het percentage flexibele arbeidscontracten. Het gaat hier om de opleidingstypen $M B O / \perp W$ verpleging en medische assistentie, WO letteren en WO econom(etr)ie en accountancy. Het percentage flexibele arbeidsrelaties neemt het sterkst toe bij VBO verkoop en handel, MBOЛLW administratief, MBOЛLW commercieel, MBO sociaal-cultureel en WO sociaal-cultureel. De opleidingen met meer dan 2.500 flexibele dienstverbanden zijn met name opleidingen op VBO- en MBO-niveau en basisonderwijs. Het percentage flexibele arbeidscontracten is het grootst bij HAVONWO bovenbouw: $16 \%$.

\section{Vast werk}

Het percentage werkenden met een vaste arbeidsrelatie is licht gedaald van 81,5 tot $80,7 \%$. Van de loontrekkenden is $91,4 \%$ in vaste dienst. Ook hier is sprake van een lichte daling.

In de helft van de bedrijfssectoren daalt het percentage werknemers met een vast dienstverband. Daarentegen stijgt het percentage werknemers met vast werk in de bedrijfssectoren chemie en energie. De sector energie is ook de sector met het hoogste percentage personen met een vaste arbeidsrelatie. De daling van het percentage werknemers met vast werk is het grootst in de metaal en elektrotechniek. In de sectoren voedings- en genotmiddelenindustrie, handel, transport, opslag en communicatie, overige commerciële dienstverlening, kwartaire diensten en overheid neemt het percentage werknemers met vast werk ook licht af.

In de meeste opleidingstypen is er sprake van een afname van het percentage werknemers met een vaste arbeidsrelatie. De afname van het vast werk is het sterkst voor werknemers met een opleidingsachtergrond wO farmacie, HBO tolk en vertaler, HBO landbouw en milieukunde en VBO installatietechniek. Het percentage werknemers met een vaste arbeidsrelatie neemt daarentegen toe bij de opleidingstypen WO informatica, WO landbouw en milieukunde, HBO politie en defensie en VBO textiel- en ledertechniek. Bij het opleidingstype $H B O$ tolk en vertaler is het percentage werknemers met vast werk 
het laagst: $80 \%$. De opleidingstypen HBO politie en defensie en HBO informatica hebben het hoogste percentage werknemers met vast werk.

In tegenstelling tot de ontwikkeling bij de totale werkzame bevolking, neemt bij de schoolverlaters die een baan hebben gevonden het percentage met een vast dienstverband bij het merendeel van de opleidingen toe. De toename van het vast werk is het grootst bij de opleidingen MBO facilitaire dienstveriening, MBO motorvoertuigentechniek, MBO horeca, VBO motorvoertuigentechniek, MBO elektrotechniek en MBO mode en kleding. Daarentegen is er sprake van een duidelijke afname van het percentage vaste dienstverbanden bij de opleidingstypen VBO bouwtechniek, HBO accountancy, VBO landen tuinbouw en $H B O$ technisch laboratorium. De schoolverlaters met een opleidingsachtergrond VBO consumptieve techniek vinden het minst vaak een vaste baan. Bij het opleidingstype $H B O$ haven en vervoer is het percentage werkende schoolverlaters met een vast contract het grootst.

\section{Uitwijkmogelijkheden}

\section{Uitwijkmogelijkheden naar verschillende bedrijfsklassen per beroepsklasse}

Bij het overgrote deel van de beroepsklassen nemen de uitwijkmogelijkheden naar andere bedrijfsklassen af. Doorgaans leidt dit echter niet altijd tot een andere typering van de uitwijkmogelijkheden. Overigens mag worden aangenomen dat de overgang van de SBI'78 naar de SBI'93 hier eveneens op van invloed is geweest. Bij de medische en paramedische beroepen blijken de uitwijkmogelijkheden naar andere bedrijfsklassen die in het algemeen al laag zijn, nog lager te zijn geworden. De spreiding over de verschillende bedrijfsklassen neemt vooral af bij de beroepsklassen winkeliers en handelaars, leerlingverpleegkundigen, zieken- en kraamverzorgenden, verkooppersoneel, maatschappelijk werkers, kinder-, gezins- en bejaardenverzorgenden en tandheelkundigen. De uitwijkmogelijkheden naar andere bedrijfsklassen voor de technische, ambachts- en industrie en de economisch-administratieve beroepen blijven het grootst.

Substitutiemogelijkheden tussen mensen met uiteenlopende opleidingsachtergronden per beroepsklasse

In het algemeen zijn bij driekwart van de beroepsklassen de substitutiemogelijkheden tussen arbeidskrachten met een verschillende opleidingsachtergrond toegenomen. De afof toename van de substitutiemogelijkheden tussen mensen met uiteenlopende opleidingsachtergronden is echter bij bijna alle opleidingen niet zo groot. De typeringen blijven dan ook nagenoeg gelijk. De substitutiemogelijkheden nemen het meest toe bij de beroepsklasse taalkundigen, tolken en vertalers. Daarentegen is de daling van de substitutiemogelijkheden het grootst bij de beroepsklasse vissers en jachtopzieners. De medische en paramedische beroepen zijn het meest afhankelijk van specifieke opleidingstypen. 
Bij het overgrote deel van de opleidingstypen nemen de uitwijkmogelijkheden naar andere bedrijfsklassen af. Ook hier zal echter de overgang van de SBI78 naar de SBI'93 waarschijnlijk van invloed zijn geweest op waargenomen verschuivingen. Bij de lager en middelbaar opgeleiden nemen de uitwijkmogelijkheden naar andere bedrijfsklassen bij vijwel alle opleidingen af. Uitzonderingen zijn de opleidingtypen $M B O / L W$ grafische techniek en MBO politie en defensie waarvoor de uitwijkmogelijkheden licht toenemen. De uitwijkmogelijkheden naar andere bedrijfsklassen nemen het sterkst af bij de opleidingstypen $M B O / L W W$ medisch laboratorium en $M B O / L W$ handel. De uitwijkmogelijkheden naar andere bedrijfsklassen nemen het sterkst toe bij het opleidingstype HBO elektrotechniek en technische informatica.

Uitwijkmogelijkheden naar verschillende beroepsgroepen op een aans/uitend of hoger functieniveau per opleidingstype

In tegenstelling tot de uitwijkmogelijkheden naar andere bedrijfsklassen nemen de uitwijkmogelijkheden naar andere beroepsgroepen op een aansluitend of hoger functieniveau juist overwegend toe. Ook dit leidt echter doorgaans niet tot een andere typering van de uitwijkmogelijkheden. De uitwijkmogelijkheden naar andere beroepsgroepen nemen het sterkst toe bij de opleidingstypen WO farmacie, HBO bedrijfsinformatica en VBO installatietechniek. Daarentegen nemen de uitwijkmogelijkheden naar andere beroepsgroepen het meest af bij de opleidingstypen MBO $L \perp W$ procestechniek en MBO bestuurlijk-juridisch. In het algemeen geldt dat met het afnemen van het opleidingsniveau de uitwijkmogelijkheden naar andere beroepsgroepen toenemen. De uitwijkmogelijkheden naar verschillende beroepsgroepen blijven dan ook het grootst bij de ongeschoolden met alleen basisonderwijs. Daarentegen zijn de uitwijkmogelijkheden het geringst bij de opleiding WO theologie.

\section{Doorstuderen}

Bij de meeste opleidingen is er sprake van een daling van het percentage gediplomeerden dat gaat verder studeren. Met het toenemen van het opleidingsniveau neemt het percentage dat doorleert af. Het percentage gediplomeerden dat doorleert neemt met name op VBO- en MBO-niveau af. Het percentage schoolverlaters dat gaat verder studeren neemt het meest af bij de opleidingen MBO assistent gezondheidszorg, MBO weg-en waterbouwkunde, MBO bestuurijk en KMBO elektrotechniek. Daarentegen neemt het percentage schoolverlaters dat gaat verder leren het sterkst toe bij de opleidingen MBO haven en vervoer, VBO textiel- en ledertechniek en VBO uiterlijke verzorging.

Bij iets meer dan de helft van de opleidingen op VBO- en (K)MBO-niveau neemt het percentage schoolverlaters dat verder gaat met een leerlingwezenopleiding af. In het algemeen neemt het percentage schoolveriaters met een technische MBO-opleiding dat 
verder gaat met een leerlingwezenopleiding toe, terwijl de schoolverlaters van deze opleidingen juist minder blijken te gaan verder studeren buiten het leerlingwezen. Het percentage schoolverlaters dat doorstroomt naar een leerlingwezenopleidingen is het meest gedaald bij de opleidingen VBO uiterlijke verzorging, VBO grafische techniek, VBO textiel- en ledertechniek, KMBO verzorging en KMBO detailhandel. Daarentegen neemt het percentage schoolverlaters dat doorleert in het leerlingwezen het meest toe bij de opleidingen VBO bouwtechniek, KMBO motorvoertuigentechniek en VBO motorvoertuigentechniek.

\section{Beloning}

De ontwikkeling van het gemiddelde nominale bruto maandloon van schoolverlaters van het $A V O, V B O, M B O$ en $\mathrm{HBO}$ laat bij verschillende opleidingen een tegengesteld beeld zien. Het gemiddelde bruto maandloon van schoolverlaters daalt vooral bij de opleidingen MBO textiel- en ledertechniek, MBO bestuurlijk en KMBO detailhandel. Daarentegen stijgt het gemiddeld bruto maandloon van schoolverlaters het meest bij de opleidingen $M B O$ haven en vervoer, MBO uiterlijke verzorging en MBO chemisch laboratorium. De schoolverlaters van de technische opleidingen op MBO-niveau hebben relatief hoge inkomens, vergeleken met de andere schoolverlaters op dit opleidingsniveau. De schoolverlaters VBO uiterlijke verzorging verdienen in 1995 gemiddeld het laagste bruto maandloon: 919 gulden. Het gemiddelde bruto maandloon bij de afgestudeerden van het HBO is het hoogst voor schoolverlaters HBO (fysio-)therapie: 3.967 gulden.

\section{(Intrede)werkloosheid}

Bij de meeste opleidingen neemt zowel de intredewerkloosheid van vier maanden of meer, als het percentage schoolverlaters dat als werkloos staat geregistreerd af. Het percentage schoolverlaters dat vier maanden na afstuderen nog geen baan had gevonden is in het algemeen bij opleidingen op VBO- en MBO-niveau lager dan bij de HBOopleidingen. Het percentage schoolverlaters dat als werkloos staat geregistreerd is daarentegen relatief hoog bij de KMBO-opleidingen.

Slechts $2 \%$ van de schoolverlaters $W W O, M B O$ haven en vervoer en HBO leraar agrarisch heeft langer dan vier maanden naar werk moeten zoeken. Daarentegen heeft $33 \%$ van de schoolverlaters $H B O$ kunst een lange zoekduur gehad. Het percentage schoolverlaters met een lange zoekduur daalt het sterkst bij de opleidingen $H B O$ technische bedrijfskunde, MBO mode en kleding, MBO haven en vervoer, MBO mechanische techniek, KMBO motorvoertuigentechniek, HBO bedrijfsinformatica en MBO bestuurlijk. Daarentegen stijgt het percentage schoolverlaters met een intredewerkloosheid van vier maanden of meer met name bij de opleidingen VBO verkoop en handel, MBO assistent gezondheidszorg en VBO bouwtechniek.

Het percentage schoolverlaters dat als werkloos staat geregistreerd is vooral afgenomen 
bij de opleidingen HBO technische bedrijfskunde, MBO sociale arbeid, HBO elektrotechniek, HBO joumalistiek en MBO chemisch laboratorium. Daarentegen is het percentage werkloze schoolverlaters met name toegenomen bij de opleidingen VBO grafische techniek, KMBO verzorging, MBO mode en kleding, KMBO detailhandel, MBO textiel- en ledertechniek en MBO haven en vervoer.

\section{Werk in de eigen vakrichting}

Meer dan de helft van de werkzame schoolverlaters met een opleiding op HBO-niveau heeft werk in de eigen vakrichting. Een uitzondering is echter de opleiding HBO toerisme waar maar $47 \%$ van de schoolverlaters werk heeft in de eigen vakrichting. Op MBOniveau loopt het percentage schoolverlaters dat werk heeft gevonden in de eigen vakrichting uiteen van 25 tot $85 \%$, op VBO-niveau van 10 tot $60 \%$. Van de schoolverlaters van de opleidingen $H B O$ accountancy en verpleegkunde werkt het hoogste percentage in de eigen vakrichting, namelijk $96 \%$. Bij de meeste opleidingen neemt het percentage schoolverlaters dat werk in de eigen vakrichting heeft af. De daling is vooral groot bij de opleidingen VBO elektrotechniek, MBO textiel- en ledertechniek, MBO sociale arbeid en $M B O$ verpleging en ziekenverzorging. Daarentegen stijgt het percentage schoolverlaters dat werkt in de eigen vakrichting vooral bij de opleidingen KMBO motorvoertuigentechniek, VBO mechanische techniek en KMBO elektrotechniek. 
1 INFORMATIE OVER BEDRIJVEN 

Figuur 1.1

Verwachte uitbreidingsvraag per bedrijfssector, 1995-2000 (gemiddeld jaarlijks percentage)

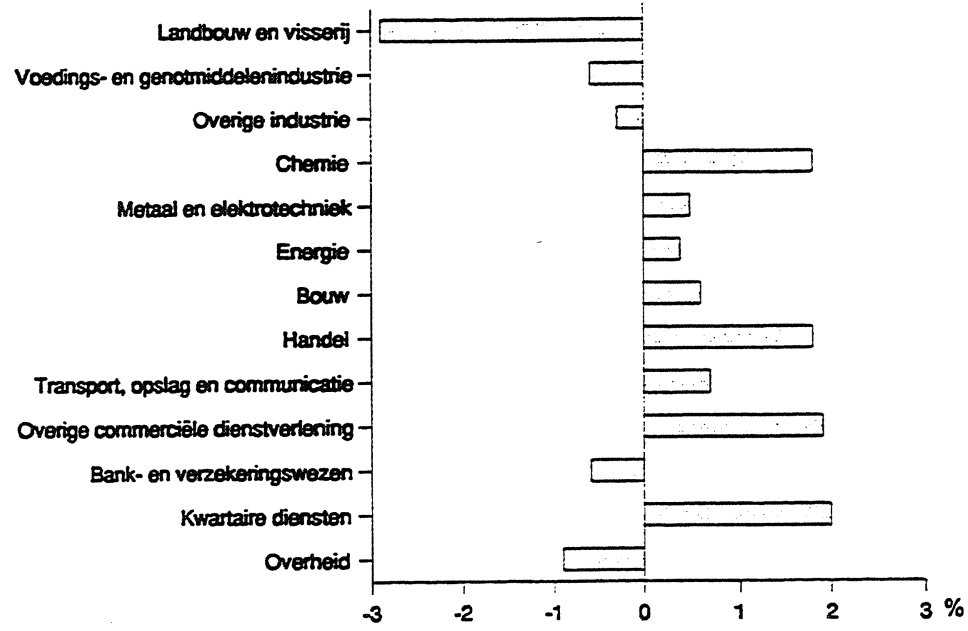

Bron: ROA 
Tabel 1.1

Aantal werkenden per bedrijfssector, gemiddelde 1994-1995

\begin{tabular}{|c|c|c|}
\hline Bedrijfssector & aantal werkenden & $\begin{array}{l}\text { trend } \\
1994-95\end{array}$ \\
\hline $\begin{array}{l}\text { Landbouw en visserij } \\
\text { Voedings- en genotmiddelenindustrie } \\
\text { Overige industrie } \\
\text { Chemie } \\
\text { Metaal en elektrotechniek } \\
\text { Energie } \\
\text { Bouw } \\
\text { Handel } \\
\text { Transport, opslag en communicatie } \\
\text { Overige commerciële dienstverlening } \\
\text { Bank- en verzekeringswezen } \\
\text { Kwartaire diensten } \\
\text { Overheid }\end{array}$ & $\begin{array}{r}230.500 \\
158.000 \\
211.000 \\
129.000 \\
495.000 \\
65.000 \\
444.000 \\
828.000 \\
379.500 \\
837.000 \\
214.000 \\
957.000 \\
911.000\end{array}$ & $\begin{array}{l}\text { dalend } \\
\text { constant } \\
\text { constant } \\
\text { constant } \\
\text { stijgend } \\
\text { dalend } \\
\text { constant } \\
\text { constant } \\
\text { constant } \\
\text { stijgend } \\
\text { stijgend } \\
\text { stijgend } \\
\text { stijgend }\end{array}$ \\
\hline
\end{tabular}

\section{Bron: CBS/ROA}

Tabel 1.2

Percentage vrouwen per bedrijfssector, gemiddelde 1994-1995

\begin{tabular}{|c|c|c|c|}
\hline Bedrijfssector & $\%$ & typering & $\begin{array}{l}\text { trend } \\
1994-95\end{array}$ \\
\hline $\begin{array}{l}\text { Landbouw en visserij } \\
\text { Voedings- en genotmiddelenindustrie } \\
\text { Overige industrie } \\
\text { Chemie } \\
\text { Metaal en elektrotechniek } \\
\text { Energie } \\
\text { Bouw } \\
\text { Handel } \\
\text { Transport, opslag en communicatie } \\
\text { Overige commerciële dienstverlening } \\
\text { Bank- en verzekeringswezen } \\
\text { Kwartaire diensten } \\
\text { Overheid }\end{array}$ & $\begin{array}{l}22 \\
28 \\
24 \\
17 \\
14 \\
14 \\
10 \\
42 \\
21 \\
39 \\
43 \\
70 \\
39\end{array}$ & $\begin{array}{l}\text { laag } \\
\text { gemiddeld } \\
\text { laag } \\
\text { laag } \\
\text { laag } \\
\text { laag } \\
\text { erg laag } \\
\text { gemiddeld } \\
\text { laag } \\
\text { gemiddeld } \\
\text { gemiddeld } \\
\text { hoog } \\
\text { gemiddeld }\end{array}$ & $\begin{array}{l}\text { dalend } \\
\text { stijgend } \\
\text { constant } \\
\text { sterk stijgend } \\
\text { constant } \\
\text { stijgend } \\
\text { dalend } \\
\text { constant } \\
\text { dalend } \\
\text { constant } \\
\text { dalend } \\
\text { constant } \\
\text { constant }\end{array}$ \\
\hline
\end{tabular}

Bron: CBS/ROA 
Tabel 1.3

Percentage jongeren (15-29 jaar) en ouderen (50-64 jaar) per bedrijfssector, gemiddelde 1994-1995

\begin{tabular}{|c|c|c|c|c|c|c|}
\hline Bedrijfssector & $\%$ & $\begin{array}{l}\text { jongeren } \\
\text { typering }\end{array}$ & $\begin{array}{l}\text { trend } \\
1994-95\end{array}$ & $\%$ & $\begin{array}{l}\text { ouderen } \\
\text { typering }\end{array}$ & $\begin{array}{l}\text { trend } \\
\text { 1994-'95 }\end{array}$ \\
\hline $\begin{array}{l}\text { Landbouw en visserij } \\
\text { Voedings- en genotmiddelenindustrie } \\
\text { Overige industrie } \\
\text { Chemie } \\
\text { Metaal en elektrotechniek } \\
\text { Energie } \\
\text { Bouw } \\
\text { Handel } \\
\text { Transport, opslag en communicatie } \\
\text { Overige commerciële dienstverlening } \\
\text { Bank- en verzekeringswezen } \\
\text { Kwartaire diensten } \\
\text { Overheid }\end{array}$ & $\begin{array}{l}30 \\
34 \\
30 \\
24 \\
27 \\
15 \\
31 \\
40 \\
26 \\
37 \\
30 \\
26 \\
17\end{array}$ & $\begin{array}{l}\text { gemiddeld } \\
\text { gemiddeld } \\
\text { gemiddeld } \\
\text { gemiddeld } \\
\text { gemiddeld } \\
\text { laag } \\
\text { gemiddeld } \\
\text { hoog } \\
\text { gemiddeld } \\
\text { hoog } \\
\text { gemiddeld } \\
\text { gemiddeld } \\
\text { laag }\end{array}$ & $\begin{array}{l}\text { constant } \\
\text { constant } \\
\text { sterk dalend } \\
\text { stijgend } \\
\text { constant } \\
\text { sterk stijgend } \\
\text { constant } \\
\text { dalend } \\
\text { constant } \\
\text { constant } \\
\text { dalend } \\
\text { dalend } \\
\text { dalend }\end{array}$ & $\begin{array}{l}25 \\
15 \\
16 \\
17 \\
15 \\
22 \\
15 \\
14 \\
13 \\
11 \\
13 \\
13 \\
18\end{array}$ & $\begin{array}{l}\text { erg hoog } \\
\text { gemiddeld } \\
\text { gemiddeld } \\
\text { gemiddeld } \\
\text { gemiddeld } \\
\text { hoog } \\
\text { gemiddeld } \\
\text { gemiddeld } \\
\text { gemiddeld } \\
\text { laag } \\
\text { gemiddeld } \\
\text { gemiddeld } \\
\text { gemiddeld }\end{array}$ & $\begin{array}{l}\text { constant } \\
\text { dalend } \\
\text { stijgend } \\
\text { stijgend } \\
\text { constant } \\
\text { sterk dalend } \\
\text { dalend } \\
\text { constant } \\
\text { stijgend } \\
\text { sterk stijgend } \\
\text { dalend } \\
\text { stijgend } \\
\text { stijgend }\end{array}$ \\
\hline
\end{tabular}

Bron: CBS/ROA

Tabel 1.4

Percentage allochtonen per bedrijfssector, gemiddelde 1994-1995

\begin{tabular}{|c|c|c|c|}
\hline Bedrijfssector & $\%$ & typering & $\begin{array}{l}\text { trend } \\
1994-95\end{array}$ \\
\hline $\begin{array}{l}\text { Landbouw en visserij } \\
\text { Voedings- en genotmiddelenindustrie } \\
\text { Overige industrie } \\
\text { Chemie } \\
\text { Metaal en elektrotechniek } \\
\text { Energie } \\
\text { Bouw } \\
\text { Handel } \\
\text { Transport, opslag en communicatie } \\
\text { Overige commerciële dienstverlening } \\
\text { Bank- en verzekeringswezen } \\
\text { Kwartaire diensten } \\
\text { Overheid }\end{array}$ & $\begin{array}{l}2 \\
7 \\
5 \\
5 \\
5 \\
2 \\
3 \\
3 \\
4 \\
3 \\
3 \\
3\end{array}$ & $\begin{array}{l}\text { laag } \\
\text { erg hoog } \\
\text { gemiddeld } \\
\text { gemiddeld } \\
\text { gemiddeld } \\
\text { gemiddeld } \\
\text { laag } \\
\text { gemiddeld } \\
\text { gemiddeld } \\
\text { gemiddeld } \\
\text { gemiddeld } \\
\text { gemiddeld } \\
\text { gemiddeld }\end{array}$ & $\begin{array}{l}\text { dalend } \\
\text { sterk dalend } \\
\text { dalend } \\
\text { dalend } \\
\text { sterk dalend } \\
\text { constant } \\
\text { sterk dalend } \\
\text { stijgend } \\
\text { sterk stijgend } \\
\text { stijgend } \\
\text { sterk stijgend } \\
\text { sterk dalend } \\
\text { dalend }\end{array}$ \\
\hline
\end{tabular}

Bron: CBS/ROA

- Het percentage heeft betrekking op de allochtonen die vallen onder de Wet Bevordering Evenredige Arbeidsdeelname Allochtonen (WBEAA). 





Tabel 1.6

Deeltijdarbeid per bedrijfssector, gemiddelde 1994-1995

\begin{tabular}{|c|c|c|c|}
\hline Bedrifissector & $\%$ & typering & $\begin{array}{l}\text { trend } \\
1994-95\end{array}$ \\
\hline $\begin{array}{l}\text { Landbouw en visserij } \\
\text { Voedings- en genotmiddelenindustrie } \\
\text { Overige industrie } \\
\text { Chemie } \\
\text { Metaal en elektrotechniek } \\
\text { Energie } \\
\text { Bouw } \\
\text { Handel } \\
\text { Transport, opslag en communicatie } \\
\text { Overige commerciële dienstverlening } \\
\text { Bank- en verzekeringswezen } \\
\text { Kwartaire diensten } \\
\text { Overheid }\end{array}$ & $\begin{array}{r}20 \\
16 \\
15 \\
9 \\
10 \\
8 \\
9 \\
27 \\
16 \\
27 \\
18 \\
53 \\
26\end{array}$ & $\begin{array}{l}\text { gemiddeld } \\
\text { gemiddeld } \\
\text { laag } \\
\text { laag } \\
\text { laag } \\
\text { laag } \\
\text { laag } \\
\text { gemiddeld } \\
\text { gemiddeld } \\
\text { gemiddeld } \\
\text { gemiddeld } \\
\text { erg hoog } \\
\text { gemiddeld }\end{array}$ & $\begin{array}{l}\text { constant } \\
\text { sterk stijgend } \\
\text { dalend } \\
\text { sterk stijgend } \\
\text { constant } \\
\text { sterk stijgend } \\
\text { constant } \\
\text { constant } \\
\text { stijgend } \\
\text { stijgend } \\
\text { dalend } \\
\text { stijgend } \\
\text { constant }\end{array}$ \\
\hline
\end{tabular}

Bron: CBS/ROA

Tabel 1.7

Zelfstandigen per bedrijfssector, gemiddelde 1994-1995

\begin{tabular}{|c|c|c|c|}
\hline Bedrijfssector & $\%$ & typering & $\begin{array}{l}\text { trend } \\
1994-95\end{array}$ \\
\hline $\begin{array}{l}\text { Landbouw en visserij } \\
\text { Voedings- en genotmiddelenindustrie } \\
\text { Overige industrie } \\
\text { Chemie } \\
\text { Metaal en elektrotechniek } \\
\text { Energie } \\
\text { Bouw } \\
\text { Handel } \\
\text { Transport, opslag en communicatie } \\
\text { Overige commerciële dienstveriening } \\
\text { Bank- en verzekeringswezen } \\
\text { Kwartaire diensten } \\
\text { Overheid }\end{array}$ & $\begin{array}{r}61 \\
5 \\
6 \\
. \\
4 \\
. \\
13 \\
16 \\
5 \\
20 \\
4 \\
9 \\
2\end{array}$ & $\begin{array}{l}\text { erg hoog } \\
\text { erg laag } \\
\text { laag } \\
\text { erg laag } \\
\text { erg laag } \\
\text { erg laag } \\
\text { gemiddeld } \\
\text { hoog } \\
\text { erg laag } \\
\text { hoog } \\
\text { erg laag } \\
\text { gemiddeld } \\
\text { erg laag }\end{array}$ & $\begin{array}{l}\text { dalend } \\
\text { sterk dalend } \\
\text { stijgend } \\
\text { sterk stijgend } \\
\text { stijgend } \\
\text { sterk dalend } \\
\text { dalend } \\
\text { sterk dalend } \\
\text { stijgend } \\
\text { dalend } \\
\text { sterk stijgend } \\
\text { dalend } \\
\text { sterk stijgend }\end{array}$ \\
\hline
\end{tabular}

Bron: CBS/ROA

- Inclusief personen die werkzaam zijn in het bedrijf of de praktijk van hun partner of ouders en freelancers e.d. 
Tabel 1.8

Flexibel werk per bedrijfssector, gemiddelde 1994-1995

\begin{tabular}{|c|c|c|c|}
\hline Bedrijfssector & $\%$ & typering & $\begin{array}{l}\text { trend } \\
1994-95\end{array}$ \\
\hline $\begin{array}{l}\text { Landbouw en visserij } \\
\text { Voedings- en genotmiddelenindustrie } \\
\text { Overige industrie } \\
\text { Chemie } \\
\text { Metaal en elektrotechniek } \\
\text { Energie } \\
\text { Bouw } \\
\text { Handel } \\
\text { Transport, opslag en communicatie } \\
\text { Overige commerciële dienstverlening } \\
\text { Bank- en verzekeringswezen } \\
\text { Kwartaire diensten } \\
\text { Overheid }\end{array}$ & $\begin{array}{r}8 \\
10 \\
7 \\
5 \\
6 \\
4 \\
4 \\
7 \\
6 \\
10 \\
4 \\
9 \\
5\end{array}$ & $\begin{array}{l}\text { gemiddeld } \\
\text { hoog } \\
\text { gemiddeld } \\
\text { laag } \\
\text { gemiddeld } \\
\text { laag } \\
\text { laag } \\
\text { gemiddeld } \\
\text { gemiddeld } \\
\text { hoog } \\
\text { laag } \\
\text { gemiddeld } \\
\text { laag }\end{array}$ & $\begin{array}{l}\text { constant } \\
\text { constant } \\
\text { stijgend } \\
\text { sterk stijgend } \\
\text { sterk stijgend } \\
\text { sterk stijgend } \\
\text { sterk stijgend } \\
\text { constant } \\
\text { sterk stijgend } \\
\text { sterk stijgend } \\
\text { constant } \\
\text { sterk stijgend } \\
\text { stijgend }\end{array}$ \\
\hline
\end{tabular}

Bron: CBS/ROA

Tabel 1.9

Percentage werknemers met vast werk per bedrijfssector, gemiddelde 1994-1995

\begin{tabular}{|c|c|c|c|}
\hline Bedrijfssector & $\%$ & typering & $\begin{array}{l}\text { trend } \\
1994-95\end{array}$ \\
\hline $\begin{array}{l}\text { Landbouw en visserij } \\
\text { Voedings- en genotmiddelenindustrie } \\
\text { Overige industrie } \\
\text { Chemie } \\
\text { Metaal en elektrotechniek } \\
\text { Energie } \\
\text { Bouw } \\
\text { Handel } \\
\text { Transport, opslag en communicatie } \\
\text { Overige commerciële dienstverlening } \\
\text { Bank- en verzekeringswezen } \\
\text { Kwartaire diensten } \\
\text { Overheid }\end{array}$ & $\begin{array}{l}80 \\
90 \\
93 \\
95 \\
94 \\
97 \\
96 \\
91 \\
93 \\
88 \\
96 \\
91\end{array}$ & $\begin{array}{l}\text { erg laag } \\
\text { laag } \\
\text { gemiddeld } \\
\text { gemiddeld } \\
\text { gemiddeld } \\
\text { hoog } \\
\text { hoog } \\
\text { laag } \\
\text { gemiddeld } \\
\text { erg laag } \\
\text { hoog } \\
\text { laag } \\
\text { gemiddeld }\end{array}$ & $\begin{array}{l}\text { sterk stijgend } \\
\text { constant } \\
\text { constant } \\
\text { constant } \\
\text { constant } \\
\text { constant } \\
\text { constant } \\
\text { constant } \\
\text { constant } \\
\text { constant } \\
\text { constant } \\
\text { constant } \\
\text { constant }\end{array}$ \\
\hline
\end{tabular}

Bron: CBS/ROA 
Tabel 1.10

Belangrijkste beroepsklassen per bedrijfssector, gemiddelde 1994-1995

\begin{tabular}{lll}
\hline Bedrijfssector & $\%$ & $\begin{array}{l}\text { trend } \\
1994-95\end{array}$ \\
\hline
\end{tabular}

\section{Landbouw en visserij}

Bedrijfsleiders in de landbouw

Uitvoerend agrarisch personeel

Andere beroepsklassen"

\section{Voedings- en genotmiddelenindustrie}

Voedings- en genotmiddelenbereiders

Expeditie-medewerkers

Bakkers en chocolademakers

Verkooppersoneel

Ondernemers, uitvoerders en bedrijfskundigen

Commercieel-administratieve employés

Chauffeurs en spoorwegpersoneel

Instrumentmakers en onderhoudsmonteurs

Andere beroepsklassen

51

33

16

12

12

9

7

5

4

3

32

\section{Overige industrie}

Productiepersoneel grafische industrie

Ondernemers, uitvoerders en bedrijfskundigen

Commercieel-administratieve employés

Timmerlieden

Journalisten en presentatoren

Houtzagers, papier- en kartonmakers

Patroonmakers, naaiers en zeilmakers

Productiepersoneel aardewerk- en glasindustrie

Filiaalhouders, inkopers en vertegenwoordigers

Expeditie-medewerkers

Administrateurs en bankemployés

Andere beroepsklassen

\section{Chemie}

Productiepersoneel chemische industrie Ondernemers, uitvoerders en bedrijfskundigen Productiepersoneel aardewerk- en glasindustrie Commercieel-administratieve employés

Chemo-technici en laboranten

Expeditie-medewerkers

Hogere leidinggevenden financiën, verkoop e.d.

Natuurkundigen, technologen en statistici

Instrumentmakers en onderhoudsmonteurs

Monteurs en controleurs elektrotechnische producten

Administrateurs en bankemployés

Andere beroepsklassen constant

constant

-

constant

sterk stijgend

dalend

stijgend

sterk dalend

sterk dalend

sterk dalend

sterk stijgend

-

\author{
stijgend \\ sterk dalend \\ dalend \\ sterk dalend \\ constant \\ sterk stijgend \\ sterk dalend \\ sterk stijgend \\ sterk stijgend \\ sterk stijgend \\ constant \\ -
}

dalend

sterk stijgend

stijgend

sterk stijgend

constant

dalend

sterk stijgend

sterk dalend

sterk dalend

sterk stijgend

sterk daiend 
Tabel 1.10 (vervolg)

Belangrijkste beroepsklassen per bedrijfssector, gemiddelde 1994-1995

Bedrijfssector $\quad \% \quad$ trend

1994-'95

\section{Metaal en elektrotechniek}

Ondememers, uitvoerders en bedrijfskundigen

Lassers, constructeurs en edelsmeden

Machinebank-, plaatwerkers en smeden

Commercieel-administratieve employés

Metaalbewerkers

Timmerlieden

Expeditie-medewerkers

Instrumentmakers en onderhoudsmonteurs

Monteurs en controleurs elektrotechnische producten

Monteurs en controleurs elektrotechnische installaties

Andere beroepsklassen

dalend

dalend

stijgend

dalend

sterk stijgend

dalend

sterk stijgend

stijgend

sterk stijgend

sterk dalend

\section{Energie}

Ondememers, uitvoerders en bedrijfskundigen 13

Commercieel-administratieve employés

Administrateurs en bankemployés

Monteurs en controleurs elektrotechnische installaties

Programmeurs en systeemanalisten

instrumentmakers en onderhoudsmonteurs

Productiepersoneel chemische industrie

Machinisten bouw en industrie

Loodgieters en installateurs

Andere beroepsklassen

Bouw

Timmerlieden

Ondememers, uitvoerders en bedrijfskundigen

Metselaars en stukadoors

Loodgieters en installateurs

Monteurs en controleurs elektrotechnische installaties

Wegenboumvakkrachten en buizenleggers

Schilders

Betonwerkers en glaszetters

Administrateurs en bankemployés

Commercieel-administratieve employés

Andere beroepsklassen

sterk stijgend sterk dalend stijgend sterk dalend sterk dalend stijgend constant sterk dalend sterk stijgend

stijgend

constant

dalend

stijgend

dalend

stijgend

dalend

sterk dalend

constant

stijgend

Handel

Verkooppersoneel

Winkeliers en handelaars

Administrateurs en bankemployés

Filiaalhouders, inkopers en vertegenwoordigers

Commercieel-administratieve employés

Expeditie-medewerkers

Andere beroepsklassen

$\begin{aligned} 25 & \text { constant } \\ 17 & \text { constant } \\ 8 & \text { dalend } \\ 6 & \text { sterk stijgend } \\ 6 & \text { dalend } \\ 5 & \text { constant } \\ 32 & -\end{aligned}$


Tabel 1.10 (vervolg)

Belangrijkste beroepsklassen per bedrijfssector, gemiddelde 1994-1995

Bedrijfssector $\%$ trend

\section{Transport, opslag en communicatie}

Chauffeurs en spoonwegpersoneel

Commercieel-administratieve employés

Postbestellers en -sorteerders

Administrateurs en bankemployés

Ondernemers, uitvoerders en bedrijfskundigen

Receptionisten, telefonisten en enquêteurs

Expeditie-medewerkers

Vliegers, verkeersieiders en expediteurs

Andere beroepsklassen

\section{Overige commerciële dienstverlening}

Keuken- en serveerpersoneel

Ondernemers, uitvoerders en bedriifskundigen

Portiers en schoonmaakpersoneel

Administrateurs en bankemployés

Leidinggevenden horeca

Programmeurs en systeemanalisten

Commercieel-administratieve employés

Automonteurs en -herstellers

Kappers en schoonheidsspecialisten

Economen en accountants

Secretaresses en typisten

Andere beroepsklassen

\section{Bank- en verzekeringswezen}

Administrateurs en bankemployés

Commercieel-administratieve employés

Filiaalhouders, inkopers en vertegenwoordigers

Ondernemers, uitvoerders en bedrijfskundigen

Programmeurs en systeemanalisten

Secretaresses en typisten

Andere beroepsklassen

\section{Kwartaire diensten}

Leerling-verpleegkundigen, zieken- en kraamverzorgenden Kinder-, gezins- en bejaardenverzorgenden

Verpleegkundigen

Maatschappelijk werkers

Portiers en schoonmaakpersoneel

Secretaresses en typisten

Artsen, medische specialisten en apothekers

Fysio, arbeids- e.a. bewegingstherapeuten

Keuken- en serveerpersoneel

Andere beroepsklassen constant

dalend

stijgend

dalend

stijgend

sterk stijgend

sterk stijgend

stijgend

\author{
dalend \\ dalend \\ dalend \\ dalend \\ sterk dalend \\ stijgend \\ sterk stijgend \\ constant \\ sterk dalend \\ sterk dalend \\ sterk stijgend
}

sterk dalend

dalend

sterk stijgend

sterk stijgend

stijgend

dalend

-

constant

stijgend

stijgend

stijgend

dalend

dalend

dalend

dalend

constant 
Tabel 1.10 (vervolg)

Belangrijkste beroepsklassen per bedrijfssector, gemiddelde 1994-1995

\begin{tabular}{lcl}
\hline Bedrijfssector & $\%$ & $\begin{array}{l}\text { trend } \\
1994-95\end{array}$ \\
& & \\
Overheid & & \\
& & \\
Docenten voortgezet onderwijs & 17 & constant \\
Commercieel-administratieve employes & 12 & sterk dalend \\
Leerkrachten basis- en speciaal onderwijs & 11 & stijgend \\
Politie en beveiligingspersoneel & 5 & stijgend \\
Administrateurs en bankemployes & 5 & sterk stijgend \\
Onderwijskundigen & 5 & stijgend \\
Beroepsmilitairen & 4 & constant \\
Andere beroepsklassen & 42 & - \\
\hline
\end{tabular}

Bron: CBS/ROA

Een uitgebreidere versie van deze tabel is opgenomen in een aparte uitgave die bij het ROA verkregen kan worden: Verdeeltabellen van bedrijfssectoren, beroepsklassen en opleidingstypen.

- Deze beroepsklassen hebben elk een werkgelegenheidsaandeel van minder dan $3 \%$. 
Tabel 1.11

Belangrijkste opleidingstypen per bedrijfssector, gemiddelde 1994-1995

\begin{tabular}{lll}
\hline Bedrijfssector & $\%$ & $\begin{array}{l}\text { trend } \\
1994-95\end{array}$ \\
& & \\
\hline
\end{tabular}

\title{
Landbouw en visserij
}

MBO/LLW landbouw en natuurlijke omgeving

VBO landbouw en natuurlijke omgeving

Basisonderwijs

VBO verzorging

MAVO, onderbouw HAVOMWO

MBO/LLW handel

Andere opleidingstypen ${ }^{-}$

\section{constant}

stijgend

stijgend

sterk dalend

constant

stijgend

Voedings- en genotmiddelenindustrie

\author{
Basisonderwijs \\ MBO/LLW consumptieve techniek \\ MAVO, onderbouw HAVOMWO \\ MBO/LLW handel \\ VBO verzorging \\ HAVONWO bovenbouw \\ VBO consumptieve techniek \\ Andere opleidingstypen
}

-

Overige industrie

\author{
Basisonderwijs \\ MBO/LLW grafische techniek \\ MAVO, onderbouw HAVOMWO \\ HAVOMWO bovenbouw \\ MBO/LLW handel \\ VBO bouwtechniek \\ MBOLLWW bouwkunde \\ VBO verzorging \\ Andere opleidingstypen
}

16

10

8

6

5

4

3

48

\author{
constant \\ dalend \\ dalend \\ sterk stijgend \\ constant \\ dalend \\ stijgend \\ -
}

\section{dalend \\ constant \\ constant \\ constant \\ stijgend \\ dalend \\ constant \\ constant}

\section{Chemie}

Basisonderwijs

MBO/LLW procestechniek

MAVO, onderbouw HAVONWO

MBOLLW handel

HBO technisch laboratorium

MBO/LLW elektrotechniek

HAVOMWO bovenbouw

VBO mechanische techniek

Andere opleidingstypen

\section{constant} sterk stijgend

constant

constant

constant

constant

stijgend

sterk stijgend

Metaal en elektrotechniek

Basisonderwijs

VBO mechanische techniek

MBO/LLW metaalkunde

14

dalend

dalend

stijgend 
Tabel 1.11 (vervolg)

Belangrijkste opleidingstypen per bedrijfssector, gemiddelde 1994-1995

\begin{tabular}{lll}
\hline Bedrijfssector & $\%$ & trend \\
& & 1994 '95
\end{tabular}

MAVO, onderbouW HAVONWO

stijgend

MBO/LLW werktuigbouwkunde

constant

MBO/LLW elektrotechniek

VBO bouwtechniek

MBO/LLW handel

Andere opleidingstypen

constant

constant

constant

Energie

MBO/LLW elektrotechniek

MBO/LLW werktuigbouwkunde

MBO/LLW handel

Basisonderwijs

$H B O$ haven en vervoer

MAVO, onderbouw HAVOMWO

Andere opleidingstypen

8

5

5

4

4

61

Bouw

MBO/LLW bouwkunde

VBO bouwtechniek

Basisonderwijs

MBO/LLW elektrotechniek

MAVO, onderbouw HAVOMWO

VBO mechanische techniek

MBO/LLW handel

VBO elektrotechniek

Andere opleidingstypen

Handel

MBO/LLW handel

MAVO, onderbouw HAVONWO

Basisonderwijs

HAVOMWO bovenbouw

VBO verzorging

Andere opleidingstypen

Transport, opslag en communicatie constant

sterk stijgend

sterk stijgend

dalend

stijgend

dalend

constant

constant

constant

constant

stijgend

sterk dalend

dalend

constant

-

constant

constant

constant

constant

dalend

dalend

constant

sterk stijgend

constant

constant

constant

constant

constant 
Tabel 1.11 (vervolg)

Belangrijkste opleidingstypen per bedrijfssector, gemiddelde 1994-1995

\begin{tabular}{lll}
\hline Bedrijfssector & $\%$ & trend \\
& & $1994-95$
\end{tabular}

\section{Overige commerciële dienstverlening}

$\begin{array}{lcl}\text { Basisonderwijs } & 9 & \text { constant } \\ \text { HAVOMWO bovenbouw } & 8 & \text { dalend } \\ \text { MAVO, onderbouw HAVONWO } & 7 & \text { constant } \\ \text { MBO/LLW verzorging } & 6 & \text { dalend } \\ \text { VBO verzorging } & 5 & \text { constant } \\ \text { MBO/LLW handel } & 4 & \text { constant } \\ \text { MBO/LLW horeca en uiterlijke verzorging } & 4 & \text { dalend } \\ \text { MBO/LLW motorvoertuigentechniek } & 4 & \text { stijgend } \\ \text { Andere opleidingstypen } & 54 & -\end{array}$

Bank- en verzekeringswezen

HAVOMWO bovenbouw

MAVO, onderbouw HAVONWO

MBO/LLW handel

MBO/LLW administratief

994-'95

Andere opleidingstypen

14 constant

10 constant

$7 \quad$ constant

$4 \quad$ constant

Kwartaire diensten

MBO/LLW verpleging en medische assistentie

$M B O / L L W$ verzorging

$H B O$ verpleging en paramedisch

HBO sociaal-cultureel

WO dier-, genees- en tandheelkunde

MAVO, onderbouw HAVONWO

VBO verzorging

Basisonderwijs

HAVOMWO bovenbouw

WO sociaat-cultureel

Andere opleidingstypen

Overheid

$\mathrm{HBO}$ onderwijs

MBO politie en defensie

MAVO, onderbouw HAVOMWO

HAVONWO bovenbouw

WO sociaal-cultureel

HBO sociaal-cultureel

MBO bestuurlijk-juridisch

Andere opleidingstypen

stijgend

dalend

constant

stijgend

constant

constant

constant

dalend

dalend

stijgend

Bron: CBS/ROA

Een uitgebreidere versie van deze tabel is opgenomen in een aparte uitgave die bij het ROA verkregen kan worden: Verdeeltabellen van bedrijfssectoren, beroepsklassen en opleidingstypen.

- Deze opleidingstypen hebben elk een werkgelegenheidsaandeel van minder dan $3 \%$. 
Tabel 1.12

Conjunctuurgevoeligheid per bedrijfssector

\begin{tabular}{lcl}
\hline Bedrijfssector & conjunctuurgevoeligheid & typering \\
\hline & 0,33 & erg laag \\
Landbouw en visserij & 0,68 & gemiddeld \\
Voedings- en genotmiddelenindustrie & 0,95 & gemiddeld \\
Overige industrie & 1,03 & hoog \\
Chemie & 1,39 & hoog \\
Metaal en elektrotechniek & 1,13 & hoog \\
Energie & 1,74 & erg hoog \\
Bouw & 0,48 & gemiddeld \\
Handel & 0,72 & gemiddeld \\
Transport, opslag en communicatie & 0,46 & laag \\
Overige commerciële dienstverlening & 0,59 & gemiddeld \\
Bank- en verzekeringswezen & 0,41 & laag \\
Kwartaire diensten & 0,47 & laag \\
Overheid & &
\end{tabular}

Bron: ROA

Tabel 1.13

Verwachte uitbreidingsvraag per bedrijfssector, 1995-2000

\begin{tabular}{|c|c|c|c|c|}
\hline Bedrijfssector & aantal & $\begin{array}{c}\text { totaal } \\
\%\end{array}$ & $\begin{array}{l}\text { gemiddeld } \\
\text { jaarlijks \% }\end{array}$ & typering \\
\hline Landbouw en visserij & -38.300 & -14 & $-2,9$ & erg laag \\
\hline Voedings- en genotmiddelenindustrie & -4.900 & -3 & $-0,6$ & laag \\
\hline Overige industrie & -3.000 & -1 & $-0,3$ & gemiddeld \\
\hline Chemie & 11.400 & 10 & 1,8 & hoog \\
\hline Metaal en elektrotechniek & 9.000 & 2 & 0,5 & gemiddeld \\
\hline Energie & 1.300 & 2 & 0,4 & gemiddeld \\
\hline Bouw & 13.000 & 3 & 0,6 & gemiddeld \\
\hline Handel & 92.200 & 10 & 1,8 & hoog \\
\hline Transport, opslag en communicatie & 12.800 & 4 & 0,7 & gemiddeld \\
\hline Overige commerciële dienstverlening & 102.400 & 10 & 1,9 & hoog \\
\hline Bank-en verzekeringswezen & -5.600 & -3 & $-0,6$ & laag \\
\hline Kwartaire diensten & 87.700 & 10 & 2,0 & hoog \\
\hline Overheid & -35.100 & -5 & $-0,9$ & laag \\
\hline
\end{tabular}

Bron: ROA 
2 INFORMATIE OVER BEROEPEN 

Figuur 2.1

Venwachte baanopeningen verdeeld naar uitbreidings- en vervangingsvraag per beroepssector, 1995-2000 (gemiddeld jaarlijks percentage)

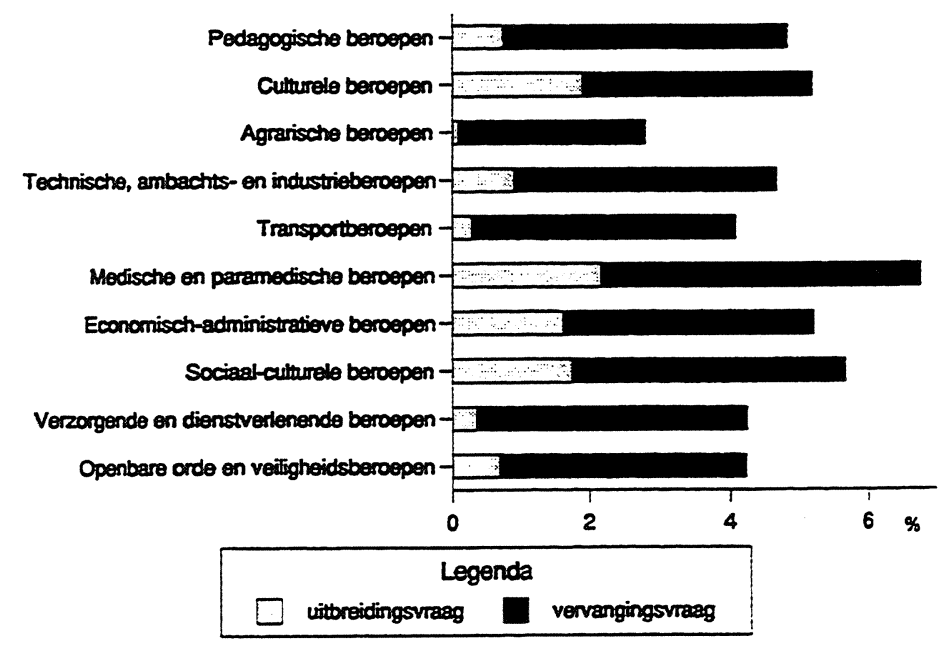

Bron: ROA 
Tabel 2.1

Aantal werkenden per beroepsklasse, gemiddelde 1994-1995

\begin{tabular}{lll}
\hline Beroepsklasse & aantal werkenden & trend \\
$1991-95$
\end{tabular}

\section{PEDAGOGISCHE BEROEPEN}

Leerkrachten basis- en speciaal onderwijs

Docenten voortgezet onderwijs

Onderwijskundigen

Sportdocenten en -instructeurs

\section{CULTURELE BEROEPEN}

Taalkundigen, tolken en vertalers

Geestelijke verzorgers

Fotografen, ontwerpers en vormgevers

Regisseurs en kunstenaars

\section{AGRARISCHE BEROEPEN}

Uitvoerend agrarisch personeel

Bedrijfsleiders in de landbouw

Landbouw en milieu-ingenieurs

TECHNISCHE, AMBACHTS- EN INDUSTRIEBEROEPEN

Heftruckrijders

Machinisten bouw en industrie

Ondernemers, uitvoerders en bedrijfskundigen

Technische en medische vertegenwoordigers

Technisch tekenaars

Chemo-technici en laboranten

Natuurkundigen, technologen en statistici

Voedings- en genotmiddelenbereiders

Bakkers en chocolademakers

Productiepersoneel textielindustrie

Stoffeerders en lederwarenmakers

Patroonmakers, naaiers en zeilmakers

Houtzagers, papier- en kartonmakers

Timmerlieden

Productiepersoneel grafische industrie

Productiepersoneel chemische industrie

Vakkrachten metaalindustrie

Metaalbewerkers

Lassers, constructeurs en edelsmeden

Machinebank-, plaatwerkers en smeden

Instrumentmakers en onderhoudsmonteurs

Automonteurs en -herstellers

Werktuigbouwkundigen

Hogere werktuigkundigen

Monteurs en controleurs elektrotechnische producten

Monteurs energievoorziening

Monteurs en controleurs elektrotechnische installaties

Elektrotechnische opzichters en uitvoerders

Elektrotechnische constructeurs en ingenieurs

Productiepersoneel aardewerk- en glasindustrie
114.000

126.000

102.500

57.000

57.000

4.500

24.000

31.500

329.500

19.000

30.000

27.000

51.500

40.500

20.500

8.000

18.500

15.000

11.000

126.000

45.000

25.000

12.000

33.000

56.500

61.000

64.500

45.500

13.500

13.000

31.500

3.000

92.500

4.500

15.000

34.000 constant

constant

sterk stijgend

sterk stijgend

sterk stijgend

dalend

-

constant

constant

sterk stijgend

dalend

dalend

-

dalend

dalend

-

dalend

constant

dalend

dalend

dalend

constant

dalend

dalend

-

sterk stijgend sterk dalend constant sterk dalend dalend dalend 
Tabel 2.1 (vervolg)

Aantal werkenden per beroepsklasse, gemiddelde 1994-1995

\begin{tabular}{lll}
\hline Beroepsklasse & aantal werkenden & trend \\
& & $1991-95$
\end{tabular}

Metselaars en stukadoors

Betonwerkers en glaszetters

Schilders

Loodgieters en installateurs

Wegenbouwvakkrachten en buizenleggers

Bouwkundige projectleiders

Architecten en bouwkundige ingenieurs

\section{TRANSPORTBEROEPEN}

\section{Expeditie-medewerkers}

Vissers en jachtopzieners

Scheepsdek- en machinekamerpersoneel

Schippers, officieren en loodsen

Chauffeurs en spoorwegpersonee

Vliegers, verkeersleiders en expediteurs

45.000

24.000

31.500

41.500

61.000

27.000

34.500

126.000

Dierenartsen en diergeneeskundigen

Tandheelkundigen

\section{ECONOMISCH-ADMINISTRATIEVE BEROEPEN}

Hogere leidinggevenden financiën, verkoop e.d.

Postbestellers en -sorteerders

Operators en datatypisten

Leidinggevend administratief personeel

Secretaresses en typisten

Bibliotheek- en archiefmedewerkers

Administrateurs en bankemployés

Commercieel-administratieve employés

Receptionisten, telefonisten en enquêteurs

Programmeurs en systeemanalisten

Economen en accountants

Verkooppersoneel

Winkeliers en handelaars

Filiaalhouders, inkopers en vertegenwoordigers

Beleidsmedewerkers en hoofdambtenaren

Advocaten, rechters en notarissen

SOCIAAL-CULTURELE BEROEPEN

Journalisten en presentatoren constant

constant

stijgend

stijgend
2.500

5.000

9.500

186.000

19.500

112.500

124.500

23.000

18.000

25.500

31.000

27.000

39.000

3.000

5.500

dalend

stijgend

constant

dalend

stijgend

stijgend

dalend

constant

constant

stijgend

106.000

37.000

9.500

25.000

136.000

19.500

351.000

357.000

83.500

129.000

57.000

265.500

172.000

137.500

28.000

32.500

dalend

sterk daiend

sterk dalend

constant

constant

constant

constant

constant

stijgend

constant 
Tabel 2.1 (vervolg)

Aantal werkenden per beroepsklasse, gemiddelde 1994-1995

\begin{tabular}{|c|c|c|}
\hline Beroepsklasse & aantal werkenden & $\begin{array}{l}\text { trend } \\
1991-95\end{array}$ \\
\hline $\begin{array}{l}\text { Bibliothecarissen en archivarissen } \\
\text { Arbeidsconsulenten en personeelsdeskundigen } \\
\text { Maatschappelijk werkers } \\
\text { Sociale wetenschappers } \\
\text { Huishoudkundige voorlichters }\end{array}$ & $\begin{array}{l}15.500 \\
33.000 \\
70.000 \\
23.500 \\
11.000\end{array}$ & $\begin{array}{l}\text { stijgend } \\
\text { constant } \\
\text { constant } \\
\text { sterk dalend }\end{array}$ \\
\hline \multicolumn{3}{|c|}{ VERZORGENDE EN DIENSTVERLENENDE BEROEPEN } \\
\hline $\begin{array}{l}\text { Keuken- en serveerpersoneel } \\
\text { Leidinggevenden horeca } \\
\text { Portiers en schoonmaakpersoneel } \\
\text { Kinder-, gezins- en bejaardenverzorgenden } \\
\text { Kappers en schoonheidsspecialisten }\end{array}$ & $\begin{array}{r}137.500 \\
63.000 \\
150.000 \\
125.500 \\
34.000\end{array}$ & $\begin{array}{l}\text { constant } \\
- \\
- \\
\text { constant } \\
\text { constant }\end{array}$ \\
\hline \multicolumn{3}{|l|}{ OPENBARE ORDE- EN VEILIGHEIDSBEROEPEN } \\
\hline $\begin{array}{l}\text { Politie en beveiligingspersoneel } \\
\text { Beroepsmilitairen }\end{array}$ & $\begin{array}{l}65.500 \\
33.500\end{array}$ & $\begin{array}{l}\text { constant } \\
\text { constant }\end{array}$ \\
\hline
\end{tabular}

Bron: CBS/ROA 
Tabel 2.2

Percentage vrouwen per beroepsklasse, gemiddelde 1994-1995

\begin{tabular}{llll}
\hline Beroepsklasse & $\%$ & typering & trend \\
$1991-' 95$ & & &
\end{tabular}

\section{PEDAGOGISCHE BEROEPEN}

Leerkrachten basis- en speciaal onderwijs

Docenten voortgezet onderwijs

Onderwijskundigen

Sportdocenten en -instructeurs

\section{CULTURELE BEROEPEN}

Taalkundigen, tolken en vertalers

Geestelijke verzorgers

Fotografen, ontwerpers en vormgevers

Regisseurs en kunstenaars

\section{AGRARISCHE BEROEPEN}

Uitvoerend agrarisch personeel

Bedrijfsleiders in de landbouw

Landbouw en milieu-ingenieurs

\section{TECHNISCHE, AMBACHTS- EN INDUSTRIEBEROEPEN}

\section{Heftruckrijders}

Machinisten bouw en industrie

Ondememers, uitvoerders en bedriifskundigen

Technische en medische vertegenwoordigers

Technisch tekenaars

Chemo-technici en laboranten

Natuurkundigen, technologen en statistici

Voedings- en genotmiddelenbereiders

Bakkers en chocolademakers

Productiepersoneel textielindustrie

Stoffeerders en lederwarenmakers

Patroonmakers, naaiers en zeilmakers

Houtzagers, papier- en kartonmakers

Timmerlieden

Productiepersoneel grafische industrie

Productiepersoneel chemische industrie

Vakkrachten metaalindustrie

Metaalbewerkers

Lassers, constructeurs en edelsmeden

Machinebank-, plaatwerkers en smeden

instrumentmakers en onderhoudsmonteurs

Automonteurs en -herstellers

Werktuigbouwkundigen

Hogere werktuigkundigen

Monteurs en controleurs elektrotechnische producten

Monteurs energievoorziening

Monteurs en controleurs elektrotechnische installaties

Elektrotechnische opzichters en uitvoerders

Elektrotechnische constructeurs en ingenieurs

Productiepersoneel aardewerk- en glasindustrie

$\begin{array}{ll}\text { hoog } & \text { constant } \\ \text { gemiddeld } & - \\ \text { gemiddeld } & \text { stijgend } \\ \text { gemiddeld } & -\end{array}$

sterk dalend sterk dalend

-

dalend

dalend stijgend

laag -

$\begin{array}{ll}\text { erg laag } & \text { - } \\ \text { erg laag } & \text { - } \\ \text { laag } & \text { stijgend } \\ \text { laag } & \text { - } \\ \text { erg laag } & \text { - } \\ \text { gemiddeld } & \text { stijgend } \\ \text { laag } & \text { dalend } \\ \text { laag } & \text { sterk dalend } \\ \text { laag } & \text { - } \\ \text { laag } & \text { - } \\ \text { gemiddeld } & \text { - } \\ \text { hoog } & \text { dalend } \\ \text { erg laag } & \text { sterk stijgend } \\ \text { erg laag } & \text { - } \\ \text { laag } & \text { constant } \\ \text { erg laag } & \text { sterk dalend } \\ \text { erg laag } & \text { - } \\ \text { erg laag } & \text { sterk dalend } \\ \text { erg laag } & \text { sterk dalend } \\ \text { erg laag } & - \\ \text { erg laag } & \text { - } \\ \text { erg laag } & \text { - } \\ \text { erg laag } & \text { - } \\ \text { erg laag } & \text { - } \\ \text { gemiddeld } & - \\ \text { erg laag } & - \\ \text { erg laag } & \text { dalend } \\ \text { erg laag } & - \\ \text { erg laag } & \text { - } \\ \text { erg laag } & \text { - } \\ & \end{array}$


Tabel 2.2 (vervolg)

Percentage vrouwen per beroepsklasse, gemiddelde 1994-1995

Beroepsklasse $\quad \% \quad$ typering trend

1991-'95

Metselaars en stukadoors

Betonwerkers en glaszetters

Schilders

Loodgieters en installateurs

Wegenbouwvakkrachten en buizenleggers

Bouwkundige projectleiders

Architecten en bouwkundige ingenieurs

\section{TRANSPORTBEROEPEN}

Expeditie-medewerkers

Vissers en jachtopzieners

Scheepsdek- en machinekamerpersoneel

Schippers, officieren en loodsen

Chauffeurs en spoorwegpersoneel

Vliegers, verkeersleiders en expediteurs

\section{MEDISCHE EN PARAMEDISCHE BEROEPEN}

Verpleegkundigen

Leerling-verpleegkundigen, zieken- en kraamverzorgenden

Dokters-, tandarts- en dierenartsassistenten

Opticiens en apothekersassistenten

Paramedische en verwante functies

Fysio, arbeids- e.a. bewegingstherapeuten

Analisten en laboranten

Artsen, medische specialisten en apothekers

Dierenartsen en diergeneeskundigen

Tandheelkundigen

\section{ECONOMISCH-ADMINISTRATIEVE BEROEPEN}

Hogere leidinggevenden financiën, verkoop e.d.

Postbestellers en -sorteerders

Operators en datatypisten

Leidinggevend administratief personeel

Secretaresses en typisten

Bibliotheek-en archiefmedewerkers

Administrateurs en bankemployés

Commercieel-administratieve employés

Receptionisten, telefonisten en enquêteurs

Programmeurs en systeemanalisten

Economen en accountants

Verkooppersoneel

Winkeliers en handelaars

Filiaalhouders, inkopers en vertegenwoordigers

Beleidsmedewerkers en hoofdambtenaren

Advocaten, rechters en notarissen

\section{SOCIAAL-CULTURELE BEROEPEN}

81

$\begin{array}{ll}\text { erg laag } & - \\ \text { erg laag } & - \\ \text { erg laag } & - \\ \text { erg laag } & - \\ \text { erg laag } & \text { constant } \\ \text { erg laag } & - \\ \text { erg laag } & \text { stijgend }\end{array}$

27 gemiddeld erg laag

erg laag

erg laag

erg laag

erg laag sterk stijgend

$\begin{array}{ll}\text { erg hoog } & - \\ \text { erg hoog } & - \\ \text { erg hoog } & - \\ \text { erg hoog } & \text { constant } \\ \text { hoog } & - \\ \text { hoog } & \text { dalend } \\ \text { hoog } & \text { constant } \\ \text { gemiddeld } & \text { stijgend } \\ \text { laag } & - \\ \text { erg laag } & \text { sterk dalend }\end{array}$

$\begin{array}{ll}\text { laag } & - \\ \text { laag } & - \\ \text { hoog } & - \\ \text { gemiddeld } & \text { sterk stijgend } \\ \text { erg hoog } & \text { constant } \\ \text { hoog } & - \\ \text { hoog } & \text { constant } \\ \text { hoog } & - \\ \text { erg hoog } & \text { constant } \\ \text { laag } & - \\ \text { laag } & - \\ \text { hoog } & - \\ \text { gemiddeld } & \text { stijgend } \\ \text { laag } & \text { stijgend } \\ \text { laag } & - \\ \text { gemiddeld } & \text { stijgend }\end{array}$

gemiddeld dalend 
Tabel 2.2 (vervolg)

Percentage vrouwen per beroepsklasse, gemiddelde 1994-1995

\begin{tabular}{|c|c|c|c|}
\hline Beroepsklasse & $\%$ & typering & $\begin{array}{l}\text { trend } \\
1991 \text {-'95 }\end{array}$ \\
\hline $\begin{array}{l}\text { Bibliothecarissen en archivarissen } \\
\text { Arbeidsconsulenten en personeelsdeskundigen } \\
\text { Maatschappelijk werkers } \\
\text { Sociale wetenschappers } \\
\text { Huishoudkundige voorlichters }\end{array}$ & $\begin{array}{l}64 \\
54 \\
67 \\
54 \\
27\end{array}$ & $\begin{array}{l}\text { hoog } \\
\text { hoog } \\
\text { hoog } \\
\text { hoog } \\
\text { gemiddeld }\end{array}$ & $\begin{array}{l}\text { stijgend } \\
\text { - } \\
\text { constant } \\
\text { constant } \\
\text { - }\end{array}$ \\
\hline \multicolumn{4}{|c|}{ VERZORGENDE EN DIENSTVERLENENDE BEROEPEN } \\
\hline $\begin{array}{l}\text { Keuken- en serveerpersoneel } \\
\text { Leidinggevenden horeca } \\
\text { Portiers en schoonmaakpersoneel } \\
\text { Kinder-, gezins- en bejaardenverzorgenden } \\
\text { Kappers en schoonheidsspecialisten }\end{array}$ & $\begin{array}{l}56 \\
38 \\
66 \\
97 \\
83\end{array}$ & $\begin{array}{l}\text { hoog } \\
\text { gemiddeld } \\
\text { hoog } \\
\text { erg hoog } \\
\text { erg hoog }\end{array}$ & $\begin{array}{l}\text { constant } \\
\text { dalend } \\
- \\
\text { - } \\
\text { constant }\end{array}$ \\
\hline \multicolumn{4}{|l|}{ OPENBARE ORDE- EN VEILIGHEIDSBEROEPEN } \\
\hline $\begin{array}{l}\text { Politie en beveiligingspersoneel } \\
\text { Beroepsmilitairen }\end{array}$ & $\begin{array}{r}14 . \\
.\end{array}$ & $\begin{array}{l}\text { laag } \\
\text { erg laag }\end{array}$ & $\begin{array}{l}\text { sterk stijgend } \\
\text { - }\end{array}$ \\
\hline
\end{tabular}

Bron: CBS/ROA 


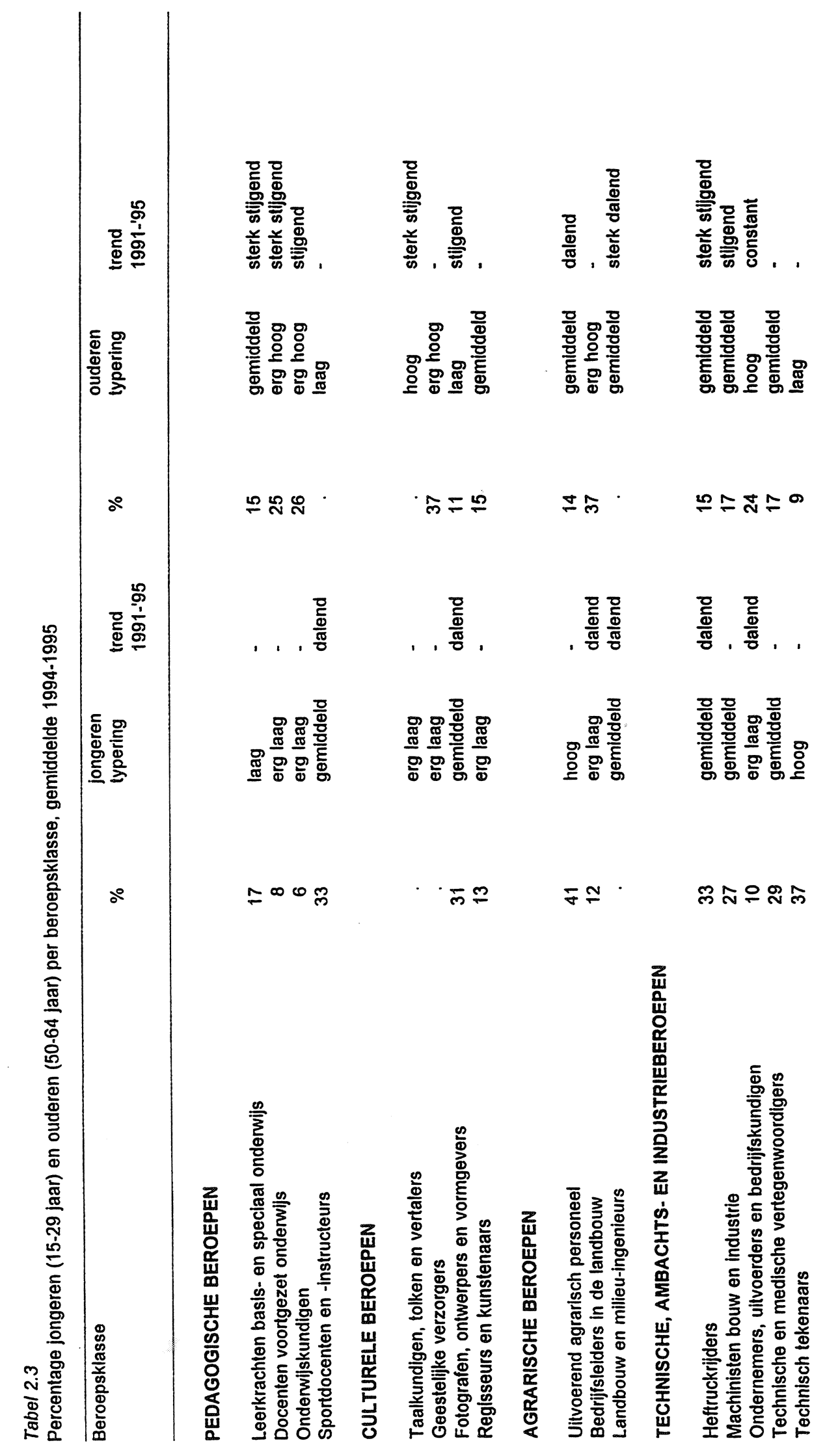




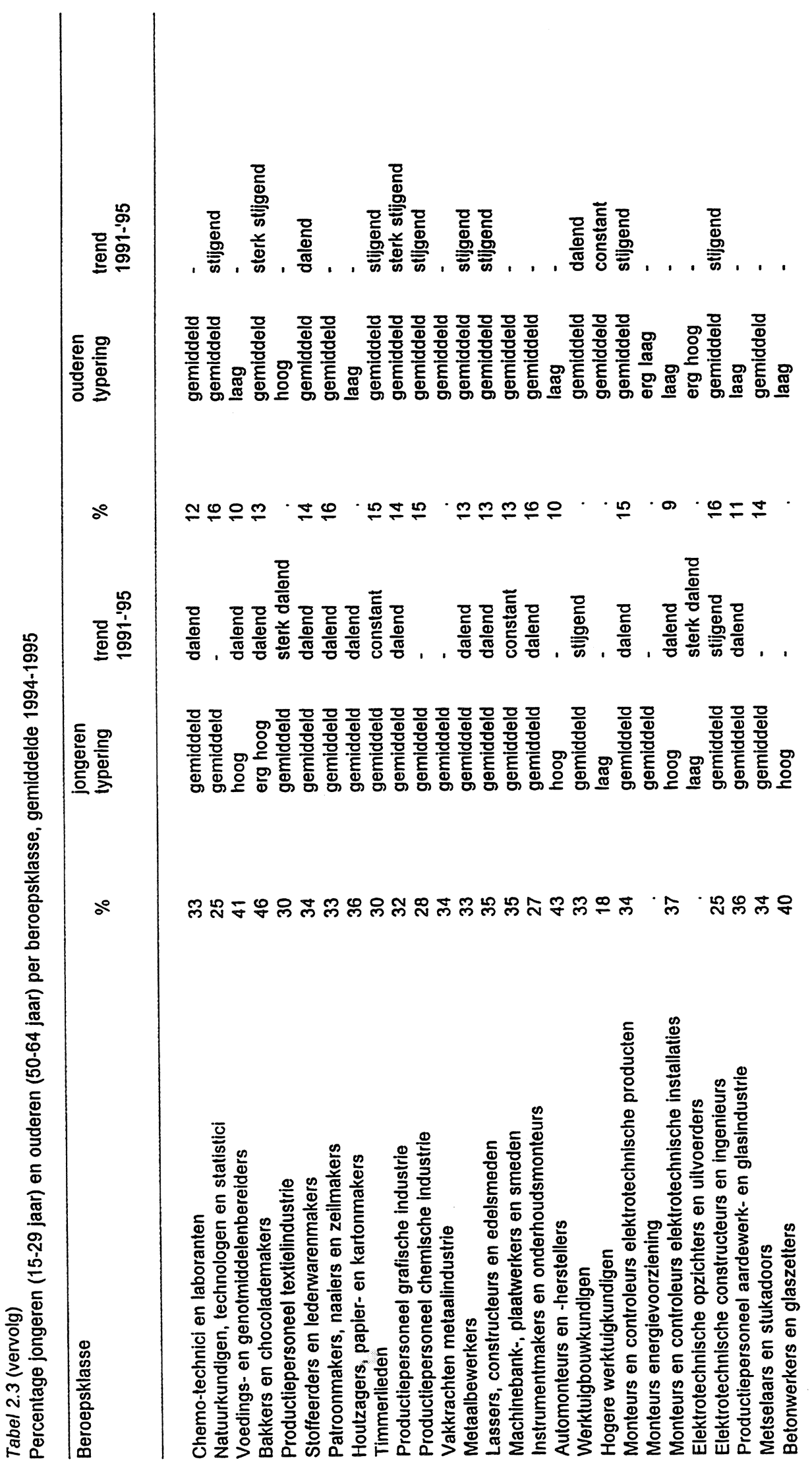




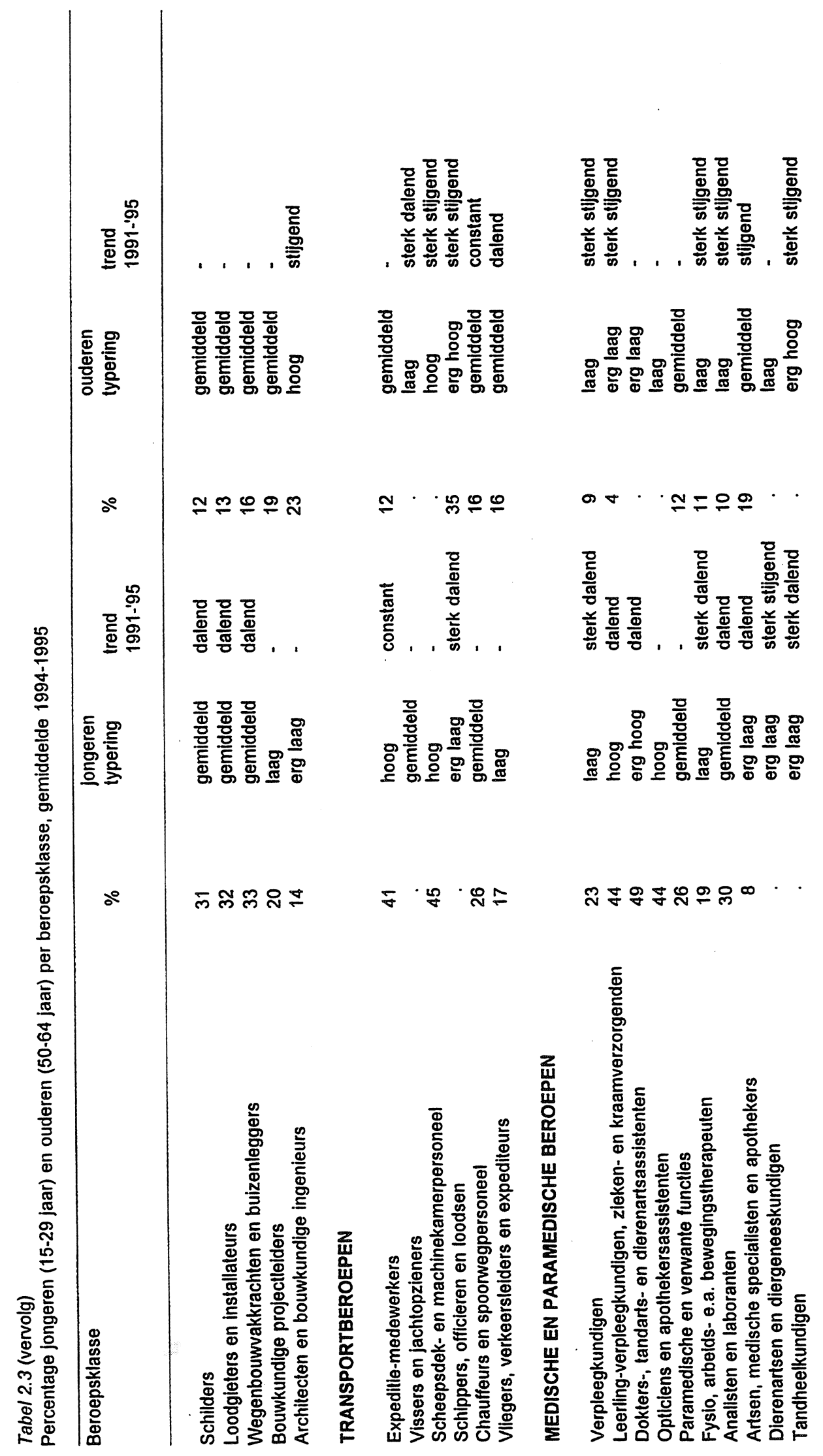




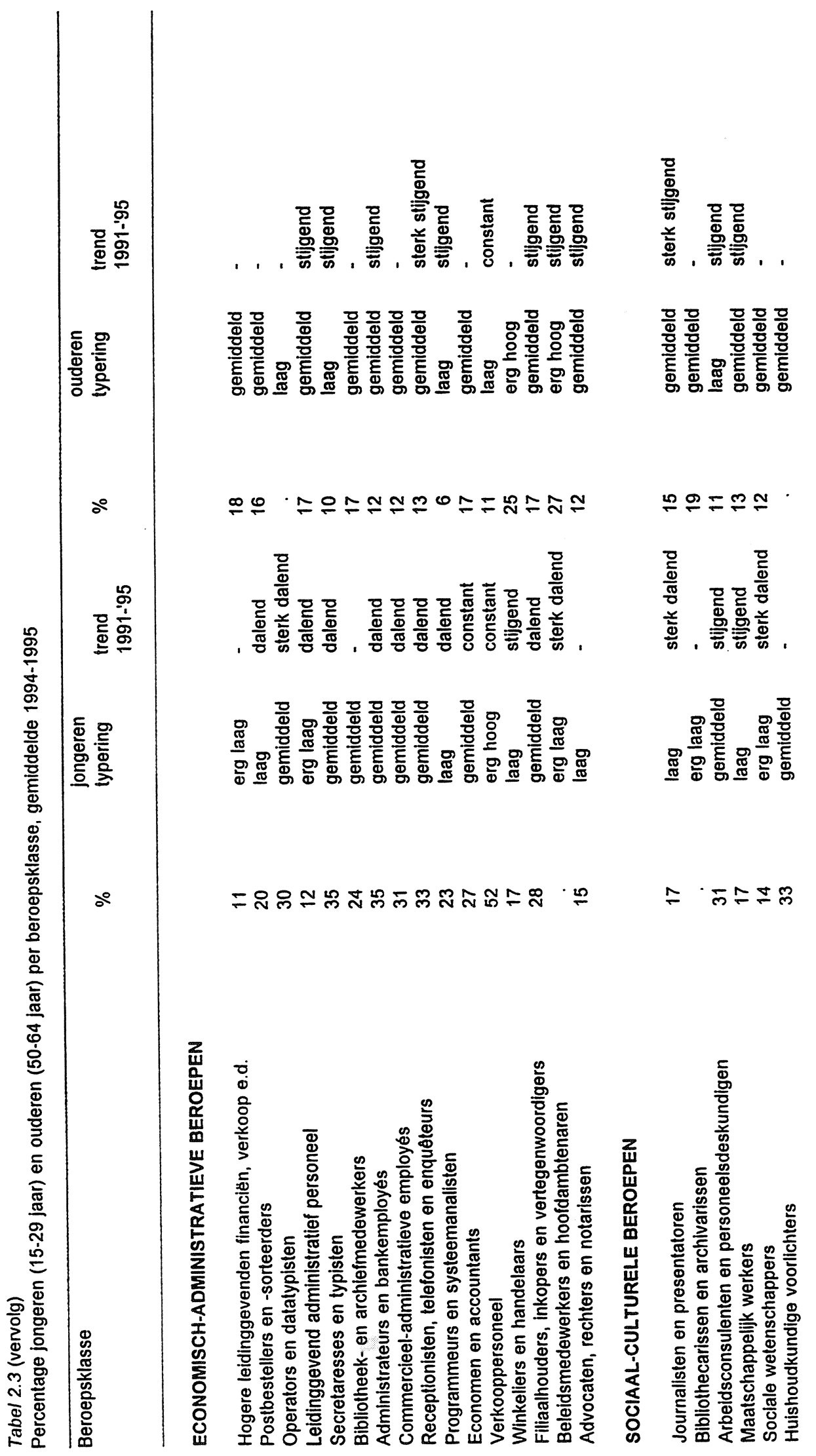




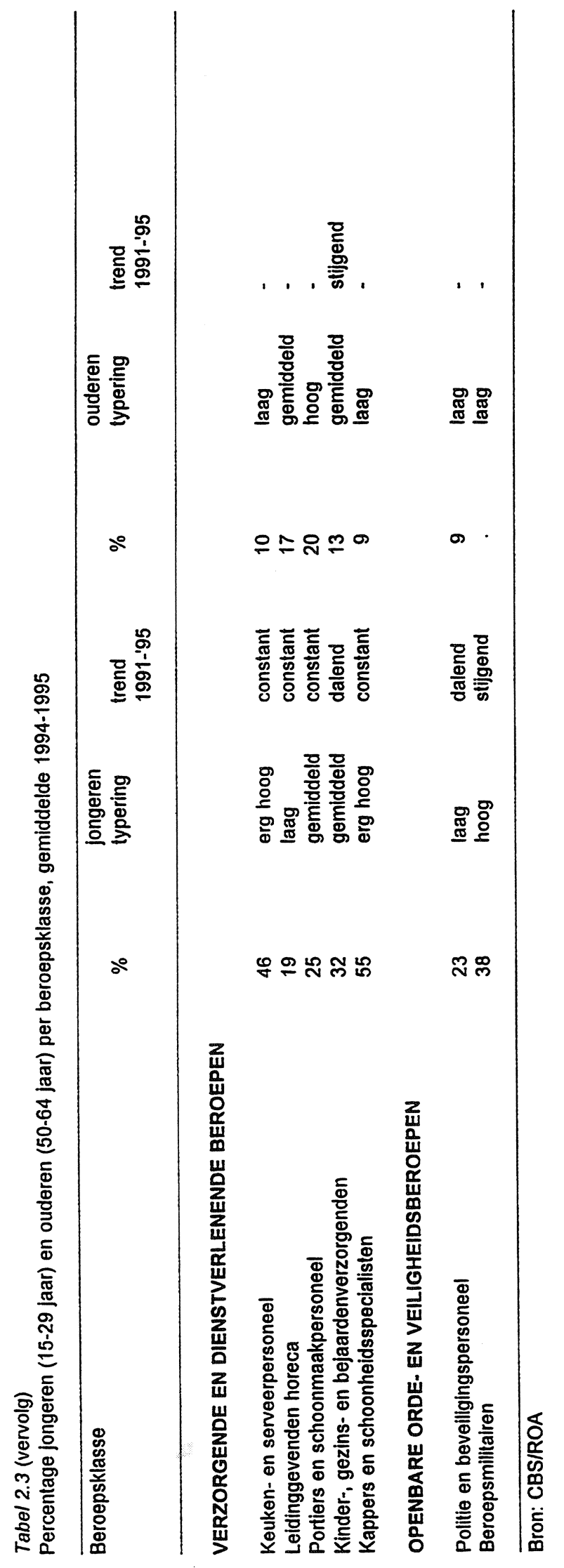


Tabel 2.4

Percentage allochtonen per beroepsklasse, gemiddelde 1994-1995

\begin{tabular}{llll}
\hline Beroepsklasse & $\%$ & typering & $\begin{array}{l}\text { trend } \\
1991-95\end{array}$ \\
& & & \\
\end{tabular}

\section{PEDAGOGISCHE BEROEPEN}

Leerkrachten basis- en speciaal onderwijs

Docenten voortgezet onderwijs

Onderwijskundigen

Sportdocenten en -instructeurs

\section{CULTURELE BEROEPEN}

Taalkundigen, tolken en vertalers

Geestelijke verzorgers

Fotografen, ontwerpers en vormgevers

Regisseurs en kunstenaars

\section{AGRARISCHE BEROEPEN}

Uitvoerend agrarisch personeel

Bedrijfsleiders in de landbouw

Landbouw en milieu-ingenieurs

\section{TECHNISCHE, AMBACHTS- EN INDUSTRIEBEROEPEN}

Heftruckrijders

Machinisten bouw en industrie

Ondernemers, uitvoerders en bedrijfskundigen

Technische en medische vertegenwoordigers

Technisch tekenaars

Chemo-technici en laboranten

Natuurkundigen, technologen en statistici

Voedings- en genotmiddelenbereiders

Bakkers en chocolademakers

Productiepersoneel textielindustrie

Stoffeerders en ledenwarenmakers

Patroonmakers, naaiers en zeilmakers

Houtzagers, papier- en kartonmakers

Timmerlieden

Productiepersoneel grafische industrie

Productiepersoneel chemische industrie

Vakkrachten metaalindustrie

Metaalbewerkers

Lassers, constructeurs en edelsmeden

Machinebank-, plaatwerkers en smeden

Instrumentmakers en onderhoudsmonteurs

Automonteurs en -herstellers

Werktuigbouwkundigen

Hogere werktuigkundigen

Monteurs en controleurs elektrotechnische producten

Monteurs energievoorziening

Monteurs en controleurs elektrotechnische installaties

Elektrotechnische opzichters en uitvoerders

Elektrotechnische constructeurs en ingenieurs

Productiepersoneel aardewerk- en glasindustrie

$\begin{array}{ll}\text { laag } & - \\ \text { laag } & - \\ \text { laag } & \text { sterk stijgend } \\ \text { laag } & -\end{array}$

laag

laag

erg laag

laag

gemiddeld

erg laag

erg laag

erg hoog

laag

erg laag

erg laag

gemiddeld

laag

laag

erg hoog

gemiddeld

erg hoog

hoog

erg hoog

hoog

laag

gemiddeld

gemiddeld

erg hoog

erg hoog

erg hoog

gemiddeld

gemiddeld

hoog

gemiddeld

erg laag

erg hoog

gemiddeld

gemiddeld

gemiddeld

erg laag

erg hoog sterk stijgend stijgend

dalend

sterk dalend

sterk stijgend sterk stijgend

-

sterk dalend

sterk dalend

stijgend

sterk stijgend

sterk dalend

dalend

dalend

sterk stijgend 
Tabel 2.4 (vervolg)

Percentage allochtonen per beroepsklasse, gemiddelde 1994-1995

Beroepsklasse
Metselaars en stukadoors
Betonwerkers en glaszetters
Schilders
Loodgieters en installateurs
Wegenbouwvakkachten en buizenleggers
Bouwkundige projectleiders
Architecten en bouwkundige ingenieurs

$\% \quad$ typering tren

1991-'95

\section{TRANSPORTBEROEPEN}

Expeditie-medewerkers

Vissers en jachtopzieners

Scheepsdek- en machinekamerpersoneel

Schippers, officieren en loodsen

Chauffeurs en spoorwegpersoneel

Vliegers, verkeersleiders en expediteurs

erg laag
gemiddeld
laag
gemiddeld
gemiddeld
erg laag
erg laag

erg hoog erg laag

erg laag

erg laag

gemiddeld

gemiddeld

\section{MEDISCHE EN PARAMEDISCHE BEROEPEN}

Verpleegkundigen

laag

gemiddeld

gemiddeld

Dokters-, tandarts- en dierenartsassistenten

Opticiens en apothekersassistenten

Paramedische en verwante functies

Fysio, arbeids- e.a. bewegingstherapeuten

Analisten en laboranten

Artsen, medische specialisten en apothekers

Dierenartsen en diergeneeskundigen

Tandheelkundigen

\section{ECONOMISCH-ADMINISTRATIEVE BEROEPEN}

Hogere leidinggevenden financiën, verkoop e.d.

Postbestellers en -sorteerders

Operators en datatypisten

Leidinggevend administratief personeel

Secretaresses en typisten

Bibliotheek- en archiefmedewerkers

Administrateurs en bankemployés

Commercieel-administratieve employés

Receptionisten, telefonisten en enquêteurs

Programmeurs en systeemanalisten

Economen en accountants

Verkooppersoneel

Winkeliers en handelaars

Filiaalhouders, inkopers en vertegenwoordigers

Beleidsmedewerkers en hoofdambtenaren

Advocaten, rechters en notarissen

\section{SOCIAAL-CULTURELE BEROEPEN}

erg laag

laag

laag

erg laag

erg laag

laag

gemiddeld

gemiddeld

gemiddeld

gemiddeld

laag

laag

erg laag

laag

erg laag

erg laag

erg laag

erg laag sterk stijgend

sterk stijgend sterk stijgend

-

$-$

$-$

sterk dalend

erg laag -

gemiddeld -

stijgend
-
sterk dalend
sterk dalend
-
-
-
-
-

erg laag -

gemiddeld sterk stijgend gemiddeld sterk dalend

stijgend

stijgend

stijgend

-

-

sterk stijgend

-

sterk dalend 
Tabel 2.4 (vervolg)

Percentage allochtonen per beroepsklasse, gemiddelde 1994-1995

Beroepsklasse $\quad \% \quad$ typering trend

$1991-' 95$

Bibliothecarissen en archivarissen

Arbeidsconsulenten en personeelsdeskundigen

Maatschappelijk werkers

laag

Sociale wetenschappers

gemiddeld

gemiddeld

Huishoudkundige voorichters

laag

gemiddeld

\section{VERZORGENDE EN DIENSTVERLENENDE BEROEPEN}

Keuken- en serveerpersoneel

Leidinggevenden horeca

5 gemiddeld sterk stijgend

Portiers en schoonmaakpersoneel

Kinder-, gezins- en bejaardenverzorgenden

Kappers en schoonheidsspecialisten

erg hoog

gemiddeld

erg laag

\section{OPENBARE ORDE- EN VEILIGHEIDSBEROEPEN}

Politie en beveiligingspersoneel

Beroepsmilitairen

4 gemiddeld

erg laag

Bron: CBS/ROA

- Het percentage heeft betrekking op allochtonen uit de landen die vallen onder de WBEAA. 


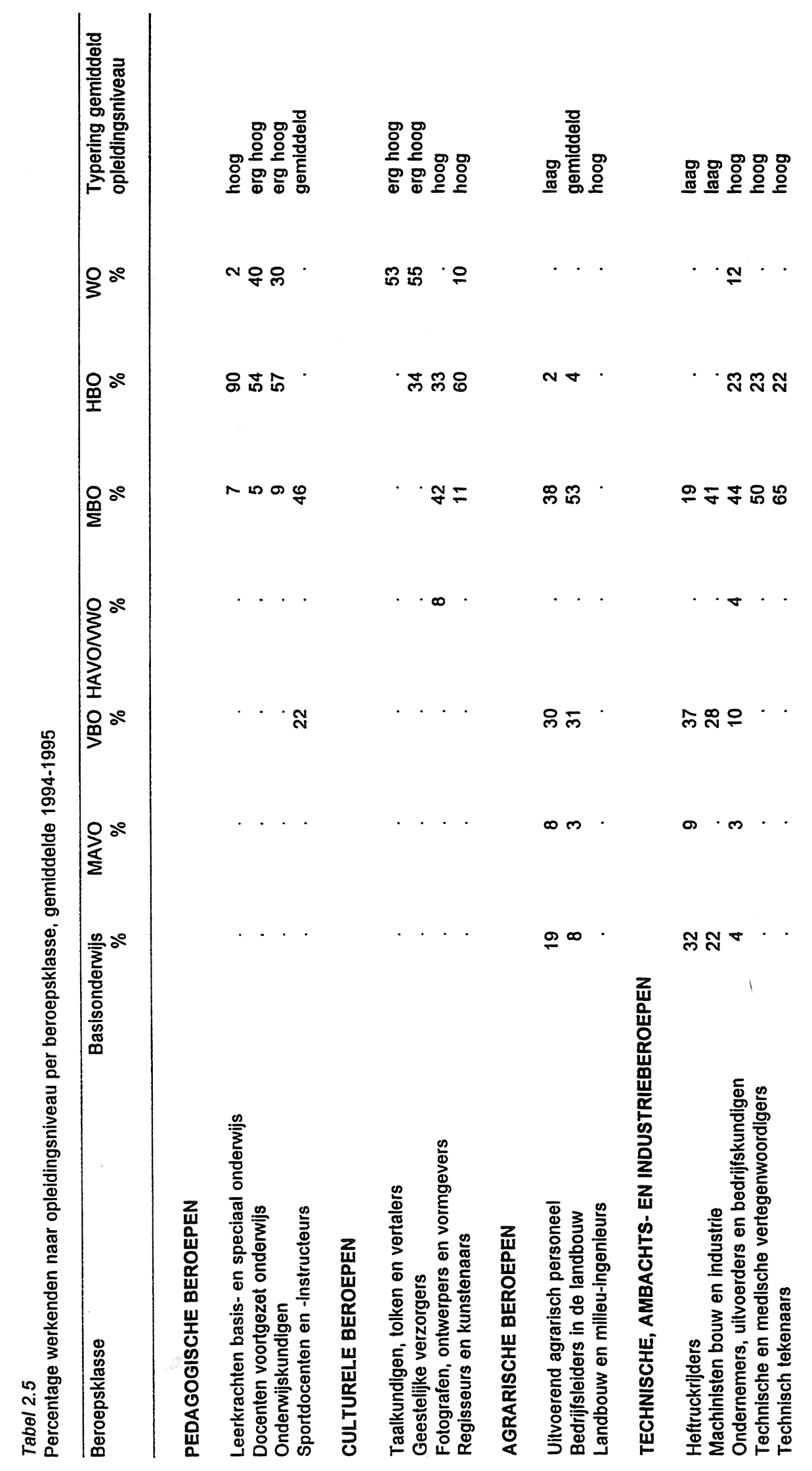




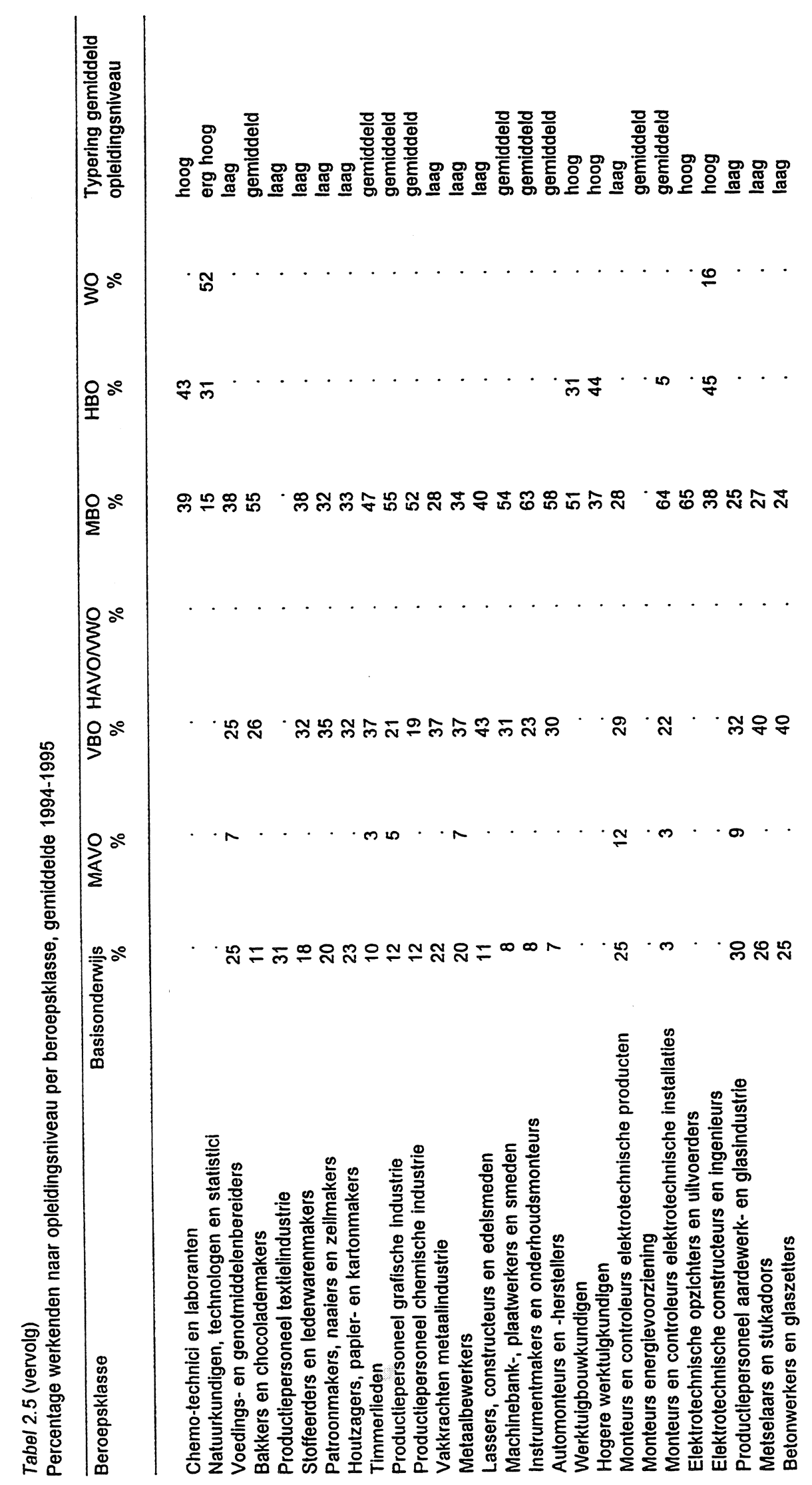




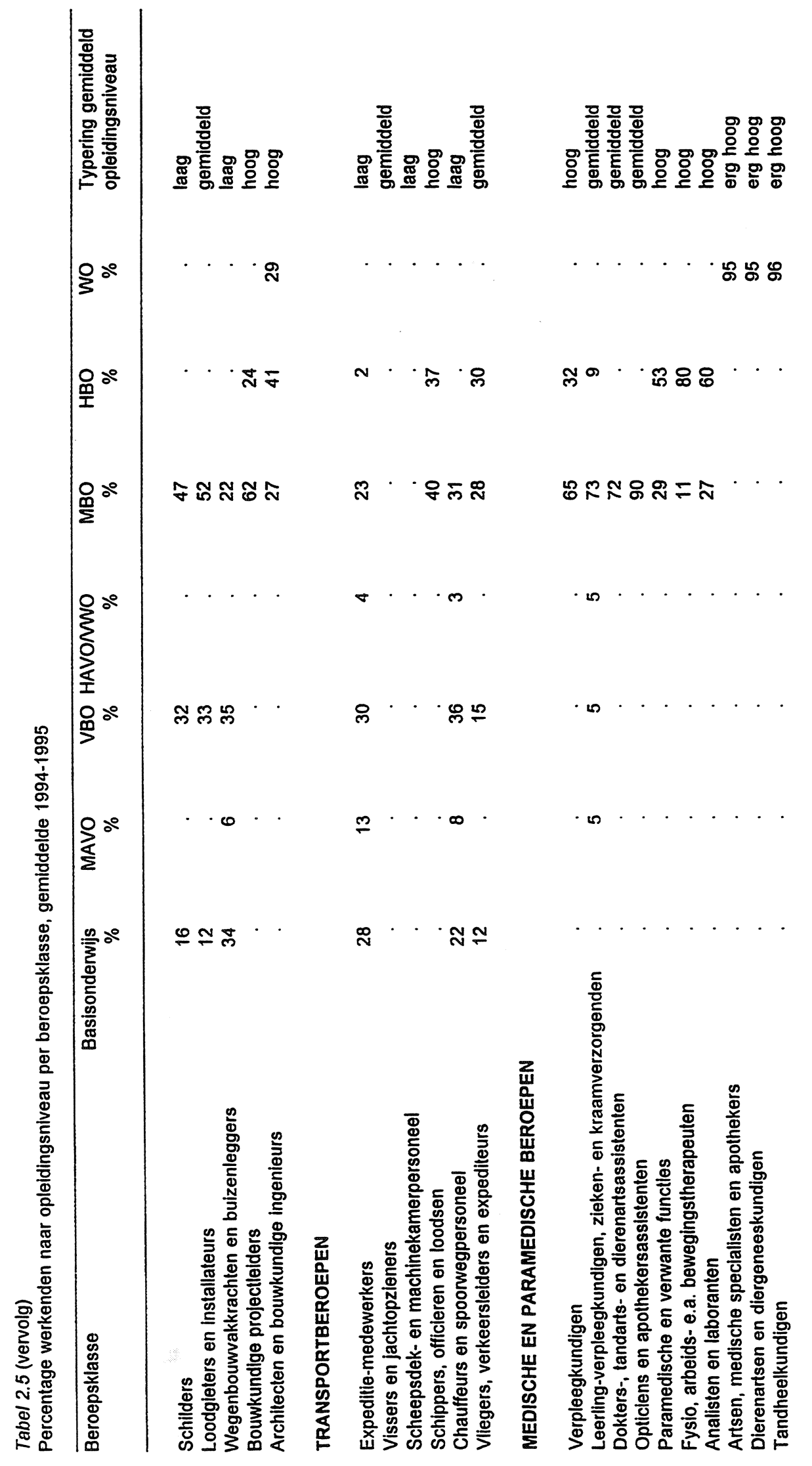




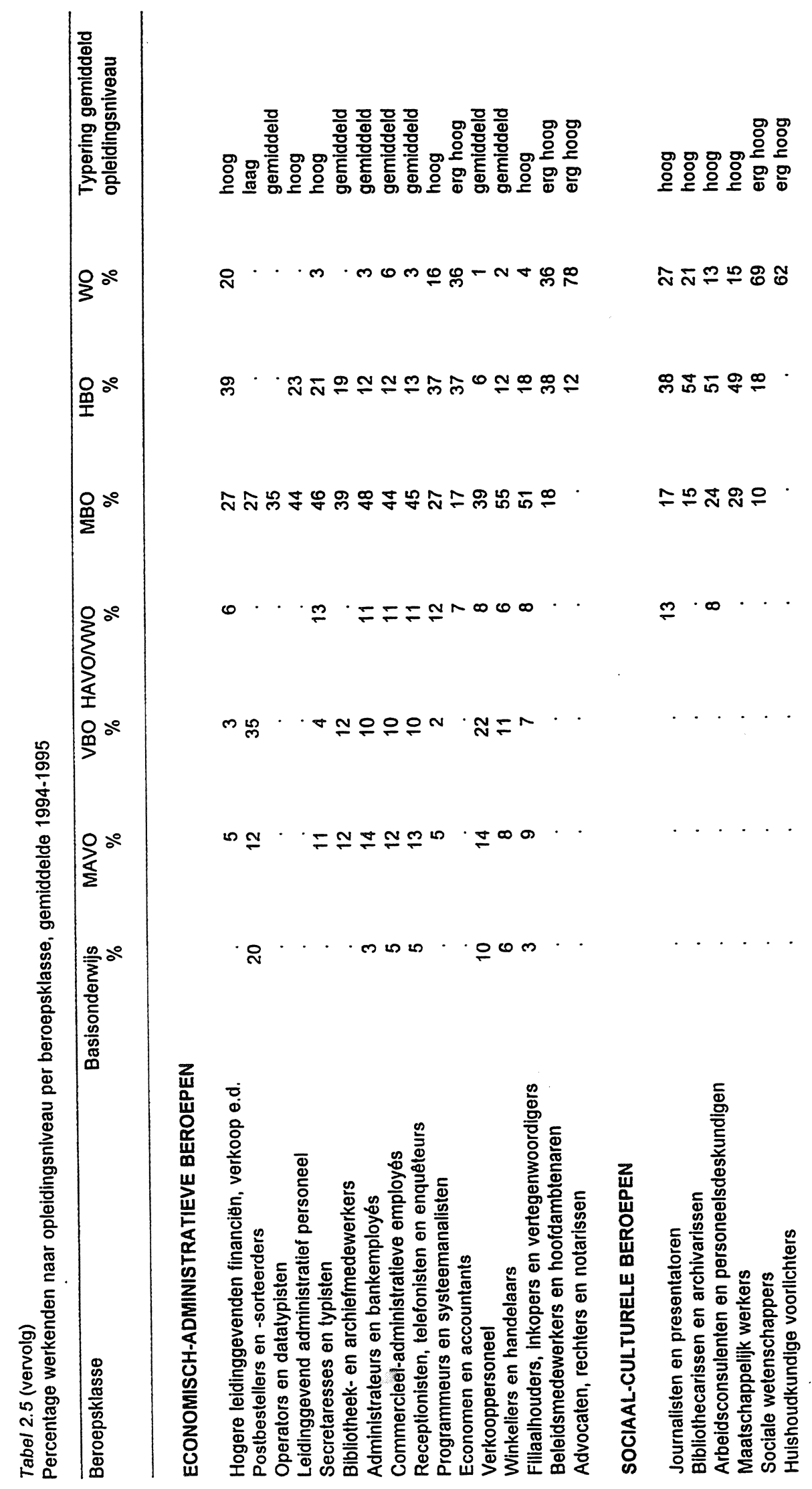







Tabel 2.6

Deeltijdarbeid per beroepsklasse, gemiddelde 1994-1995

\begin{tabular}{llll}
\hline Beroepsklasse & $\%$ & typering & $\begin{array}{c}\text { trend } \\
1991-' 95\end{array}$ \\
& &
\end{tabular}

\section{PEDAGOGISCHE BEROEPEN}

Leerkrachten basis- en speciaal onderwijs

Docenten voortgezet onderwijs

Onderwijskundigen

Sportdocenten en -instructeurs

\section{CULTURELE BEROEPEN}

Taalkundigen, tolken en vertalers

Geestelijke verzorgers

Fotografen, ontwerpers en vormgevers

Regisseurs en kunstenaars

\section{AGRARISCHE BEROEPEN}

Uitvoerend agrarisch personeel

Bedrijfsleiders in de landbouw

Landbouw en milieu-ingenieurs

\section{TECHNISCHE, AMBACHTS- EN INDUSTRIEBEROEPEN}

\section{Heftruckrijders}

Machinisten bouw en industrie

Ondernemers, uitvoerders en bedrijfskundigen

Technische en medische vertegenwoordigers

Technisch tekenaars

Chemo-technici en laboranten

Natuurkundigen, technologen en statistici

Voedings- en genotmiddelenbereiders

Bakkers en chocolademakers

Productiepersoneel textielindustrie

Stoffeerders en lederwarenmakers

Patroonmakers, naaiers en zeilmakers

Houtzagers, papier- en kartonmakers

Timmerlieden

Productiepersoneel grafische industrie

Productiepersoneel chemische industrie

Vakkrachten metaalindustrie

Metaalbewerkers

Lassers, constructeurs en edelsmeden

Machinebank-, plaatwerkers en smeden

Instrumentmakers en onderhoudsmonteurs

Automonteurs en -hersteliers

Werktuigbouwkundigen

Hogere werktuigkundigen

Monteurs en controleurs elektrotechnische producten

Monteurs energievoorziening

Monteurs en controleurs elektrotechnische installaties

Elektrotechnische opzichters en uitvoerders

Elektrotechnische constructeurs en ingenieurs

Productiepersoneel aardewerk- en glasindustrie

$\begin{array}{ll}\text { hoog } & - \\ \text { gemiddeld } & \text { sterk dalend } \\ \text { gemiddeld } & - \\ \text { hoog } & -\end{array}$

hoog

gemiddeld

gemiddeld

hoog

gemiddeld

laag

laag

dalend

stijgend

-

dalend

erg laag

erg laag

laag

erg laag

erg laag

gemiddeld

laag

laag

laag

laag

laag

hoog

laag

laag

laag

laag

erg laag

laag

erg laag

erg laag

erg laag

laag

erg laag

erg laag

laag

erg laag

laag

erg laag

erg laag

laag sterk dalend

-

dalend

-

-

$-$

sterk dalend

dalend

-

-

dalend

sterk dalend

dalend

-

sterk dalend

-

-

-

stijgend

- 
Tabel 2.6 (vervolg)

Deeltijdarbeid per beroepsklasse, gemiddelde 1994-1995

\begin{tabular}{llll}
\hline Beroepsklasse & $\%$ & typering & trend
\end{tabular}

1991-'95

Metselaars en stukadoors

Betonwerkers en glaszetters

Schilders

Loodgieters en installateurs

Wegenbouwvakkrachten en buizenleggers

Bouwkundige projectleiders

Architecten en bouwkundige ingenieurs

\section{TRANSPORTBEROEPEN}

Expeditie-medewerkers

Vissers en jachtopzieners

Scheepsdek- en machinekamerpersoneel

Schippers, officieren en loodsen

Chauffeurs en spoorwegpersoneel

Vliegers, verkeersleiders en expediteurs

\section{MEDISCHE EN PARAMEDISCHE BEROEPEN}

Verpleegkundigen

Leerling-verpleegkundigen, zieken- en kraamverzorgenden

Dokters-, tandarts- en dierenartsassistenten

Opticiens en apothekersassistenten

Paramedische en verwante functies

Fysio, arbeids- e.a. bewegingstherapeuten

Analisten en laboranten

Artsen, medische specialisten en apothekers

Dierenartsen en diergeneeskundigen

Tandheelkundigen

\section{ECONOMISCH-ADMINISTRATIEVE BEROEPEN}

Hogere leidinggevenden financiën, verkoop e.d.

Postbestellers en -sorteerders

Operators en datatypisten

Leidinggevend administratief personeel

Secretaresses en typisten

Bibliotheek- en archiefmedewerkers

Administrateurs en bankemployés

Commercieel-administratieve employés

Receptionisten, telefonisten en enquêteurs

Programmeurs en systeemanalisten

Economen en accountants

Verkooppersoneel

Winkeliers en handelaars

Filiaalhouders, inkopers en vertegenwoordigers

Beleidsmedewerkers en hoofdambtenaren

Advocaten, rechters en notarissen

SOCIAAL-CULTURELE BEROEPEN

Journalisten en presentatoren erg laag -

erg laag -

laag dalend

erg laag .

laag

erg laag

laag

gemiddeld stijgend

erg laag

erg laag

erg laag

laag

laag

sterk dalend

sterk dalend

sterk stijgend

$\begin{array}{ll}\text { erg hoog } & \begin{array}{l}\text { stijgend } \\ \text { erg hoog }\end{array} \\ \text { stijgend } \\ \text { erg hoog } & \begin{array}{l}\text { stijgend } \\ \text { stijgend }\end{array} \\ \text { hoog } & \text { constant } \\ \text { hoog } & \text { - } \\ \text { erg hoog } & \text { stijgend } \\ \text { hoog } & \text { - } \\ \text { gemiddeld } & \text { sterk stijgend } \\ \text { laag } & - \\ \text { laag } & -\end{array}$

laag

gemiddeld

hoog

laag

hoog

hoog

gemiddeld

gemiddeld

hoog

laag

laag

hoog

laag

laag

laag

gemiddeld

stijgend

stijgend

sterk stijgend

stijgend

stijgend

stijgend

constant

-

sterk dalend

constant

stijgend

sterk dalend

stijgend

gemiddeld stijgend 
Tabel 2.6 (vervolg)

Deeltijdarbeid per beroepsklasse, gemiddelde 1994-1995

\begin{tabular}{|c|c|c|c|}
\hline Beroepsklasse & $\%$ & typering & $\begin{array}{l}\text { trend } \\
\text { 1991-'95 }\end{array}$ \\
\hline $\begin{array}{l}\text { Bibliothecarissen en archivarissen } \\
\text { Arbeidsconsulenten en personeelsdeskundigen } \\
\text { Maatschappelijk werkers } \\
\text { Sociale wetenschappers } \\
\text { Huishoudkundige voorlichters }\end{array}$ & $\begin{array}{l}43 \\
25 \\
57 \\
49 \\
.\end{array}$ & $\begin{array}{l}\text { hoog } \\
\text { gemiddeld } \\
\text { erg hoog } \\
\text { hoog } \\
\text { laag }\end{array}$ & $\begin{array}{l}\text { stijgend } \\
\text { stijgend } \\
\text { stijgend } \\
\text { stijgend } \\
\text { dalend }\end{array}$ \\
\hline \multicolumn{4}{|c|}{ VERZORGENDE EN DIENSTVERLENENDE BEROEPEN } \\
\hline $\begin{array}{l}\text { Keuken- en serveerpersoneel } \\
\text { Leidinggevenden horeca } \\
\text { Portiers en schoonmaakpersoneel } \\
\text { Kinder-, gezins- en bejaardenverzorgenden } \\
\text { Kappers en schoonheidsspecialisten }\end{array}$ & $\begin{array}{l}53 \\
15 \\
60 \\
78 \\
51\end{array}$ & $\begin{array}{l}\text { erg hoog } \\
\text { laag } \\
\text { erg hoog } \\
\text { erg hoog } \\
\text { erg hoog }\end{array}$ & $\begin{array}{l}\text { constant } \\
\text { dalend } \\
\text { constant } \\
\text { constant } \\
\text { constant }\end{array}$ \\
\hline \multicolumn{4}{|l|}{ OPENBARE ORDE- EN VEILIGHEIDSBEROEPEN } \\
\hline $\begin{array}{l}\text { Politie en beveiligingspersoneel } \\
\text { Beroepsmilitairen }\end{array}$ & 8 & $\begin{array}{l}\text { laag } \\
\text { erg laag }\end{array}$ & sterk stijgend \\
\hline
\end{tabular}

Bron: CBS/ROA 
Tabel 2.7

Zelfstandigen per beroepsklasse, gemiddelde 1994-1995

\begin{tabular}{llll}
\hline Beroepsklasse & $\%$ & typering & trend \\
$1993-95$
\end{tabular}

PEDAGOGISCHE BEROEPEN

Leerkrachten basis- en speciaal onderwijs

Docenten voortgezet onderwijs

Onderwijskundigen

Sportdocenten en -instructeurs

\section{CULTURELE BEROEPEN}

Taalkundigen, tolken en vertalers

Geestelijke verzorgers

Fotografen, ontwerpers en vormgevers

Regisseurs en kunstenaars

$\begin{array}{ll}\text { erg hoog } & \text { sterk stijgend } \\ \text { erg hoog } & \text { sterk stijgend } \\ \text { erg hoog } & \text { stijgend }\end{array}$

\section{AGRARISCHE BEROEPEN}

Uitvoerend agrarisch personeel

Bedrijfsleiders in de landbouw

Landbouw en milieu-ingenieurs

TECHNISCHE, AMBACHTS- EN INDUSTRIEBEROEPEN

Heftruckrijders

Machinisten bouw en industrie

Ondernemers, uitvoerders en bedrijfskundigen

Technische en medische vertegenwoordigers

Technisch tekenaars

Chemo-technici en laboranten

Natuurkundigen, technologen en statistici

Voedings- en genotmiddelenbereiders

Bakkers en chocolademakers

Productiepersoneel textielindustrie

Stoffeerders en lederwarenmakers

Patroonmakers, naaiers en zeilmakers

Houtzagers, papier- en kartonmakers

Timmerlieden

Productiepersoneel grafische industrie

Productiepersoneel chemische industrie

Vakkrachten metaalindustrie

Metaalbewerkers

Lassers, constructeurs en edelsmeden

Machinebank-, plaatwerkers en smeden

instrumentmakers en onderhoudsmonteurs

Automonteurs en -herstellers

Werktuigbouwkundigen

Hogere werktuigkundigen

Monteurs en controleurs elektrotechnische producten

Monteurs energievoorziening

Monteurs en controleurs elektrotechnische installaties hoog

erg hoog

laag

sterk dalend constant

$-$

$\begin{array}{ll}\text { erg laag } & \text { - } \\ \text { erg laag } & \text { sterk dalend } \\ \text { hoog } & \text { - } \\ \text { erg laag } & \text { - } \\ \text { erg laag } & \text { sterk stijgend } \\ \text { erg laag } & \text { - } \\ \text { erg laag } & \text { sterk dalend } \\ \text { erg laag } & \text { stijgend } \\ \text { hoog } & \text { sterk stijgend } \\ \text { erg laag } & \text { sterk stijgend } \\ \text { hoog } & \text { constant } \\ \text { hoog } & \text { - } \\ \text { erg laag } & \text { - } \\ \text { gemiddeld } & \text { sterk stijgend } \\ \text { gemiddeld } & \text { sterk stijgend } \\ \text { erg laag } & \text { - } \\ \text { erg laag } & \text { - } \\ \text { erg laag } & \text { - } \\ \text { erg laag } & \text { - } \\ \text { erg laag } & \text { sterk stijgend } \\ \text { laag } & \text { sterk stijgend } \\ \text { gemiddeld } & - \\ \text { erg laag } & - \\ \text { erg laag } & - \\ \text { erg laag } & \text { sterk stijgend } \\ \text { erg laag } & - \\ \text { erg laag } & \text { sterk stijgend }\end{array}$


Tabel 2.7 (vervolg)

Zelfstandigen per beroepsklasse, gemiddelde 1994-1995

\begin{tabular}{llll}
\hline Beroepsklasse & $\%$ & typering & trend \\
$1993-5$
\end{tabular}

$1993-' 95$

Elektrotechnische opzichters en uitvoerders

Elektrotechnische constructeurs en ingenieurs

Productiepersoneel aardewerk- en glasindustrie

Metselaars en stukadoors

Betonwerkers en glaszetters

Schilders

Loodgieters en installateurs

Wegenbouwvakkrachten en buizenleggers

Bouwkundige projectleiders

Architecten en bouwkundige ingenieurs

\section{TRANSPORTBEROEPEN}

Expeditie-medewerkers

Vissers en jachtopzieners

Scheepsdek- en machinekamerpersoneel

Schippers, officieren en loodsen

Chauffeurs en spoorwegpersonee

Vliegers, verkeersleiders en expediteurs

\section{MEDISCHE EN PARAMEDISCHE BEROEPEN}

Verpleegkundigen

Leerling-verpleegkundigen, zieken- en kraamverzorgenden

Dokters-, tandarts- en dierenartsassistenten

Opticiens en apothekersassistenten

Paramedische en verwante functies

Fysio, arbeids- e.a. bewegingstherapeuten

Analisten en laboranten

Artsen, medische specialisten en apothekers

Dierenartsen en diergeneeskundigen

Tandheelkundigen

\section{ECONOMISCH-ADMINISTRATIEVE BEROEPEN}

Hogere leidinggevenden financiën, verkoop e.d.

Postbestellers en -sorteerders

Operators en datatypisten

Leidinggevend administratief personeel

Secretaresses en typisten

Bibliotheek- en archiefmedewerkers

Administrateurs en bankemployés

Commercieel-administratieve employés

Receptionisten, telefonisten en enquêteurs

Programmeurs en systeemanalisten

Economen en accountants

Verkooppersoneel

Winkeliers en handelaars

Filiaalhouders, inkopers en vertegenwoordigers erg laag

$\begin{array}{ll}\text { erg laag } & \text { sterk stijgend } \\ \text { erg laag } & \text { sterk stijgend } \\ \text { erg laag } & - \\ \text { gemiddeld } & - \\ \text { gemiddeld } & \text { sterk stijgend } \\ \text { gemiddeld } & \text { sterk stijgend } \\ \text { laag } & - \\ \text { laag } & \text { sterk stijgend } \\ \text { erg laag } & \text { sterk dalend } \\ \text { gemiddeld } & \text { sterk dalend }\end{array}$

$\begin{array}{ll}\text { erg laag } & \text { sterk stijgend } \\ \text { erg hoog } & - \\ \text { laag } & - \\ \text { hoog } & \text { sterk dalend } \\ \text { gemiddeld } & \text { sterk stijgend } \\ \text { erg laag } & -\end{array}$

erg laag

erg laag

erg laag

erg laag

erg hoog

erg hoog

erg laag

erg hoog

erg hoog

erg hoog

sterk stijgend sterk stijgend

sterk dalend

constant

sterk dalend

90

$\begin{array}{ll}\text { erg laag } & \text { sterk stijgend } \\ \text { erg laag } & \text { sterk stijgend } \\ \text { erg laag } & - \\ \text { erg laag } & - \\ \text { erg laag } & - \\ \text { erg laag } & - \\ \text { erg laag } & - \\ \text { erg laag } & \text { sterk stijgend } \\ \text { erg laag } & \text { dalend } \\ \text { erg laag } & - \\ \text { hoog } & \text { stijgend } \\ \text { laag } & \text { sterk dalend } \\ \text { erg hoog } & - \\ \text { gemiddeld } & -\end{array}$


Tabel 2.7 (vervolg)

Zelfstandigen per beroepsklasse, gemiddelde 1994-1995

\begin{tabular}{|c|c|c|c|}
\hline Beroepsklasse & $\%$ & typering & $\begin{array}{l}\text { trend } \\
1993-95\end{array}$ \\
\hline $\begin{array}{l}\text { Beleidsmedewerkers en hoofdambtenaren } \\
\text { Advocaten, rechters en notarissen }\end{array}$ & 21 & $\begin{array}{l}\text { erg laag } \\
\text { hoog }\end{array}$ & - \\
\hline \multicolumn{4}{|l|}{ SOCIAAL-CULTURELE BEROEPEN } \\
\hline $\begin{array}{l}\text { Journalisten en presentatoren } \\
\text { Bibliothecarissen en archivarissen } \\
\text { Arbeidsconsulenten en personeelsdeskundigen } \\
\text { Maatschappelijk werkers } \\
\text { Sociale wetenschappers } \\
\text { Huishoudkundige voorlichters }\end{array}$ & $\begin{array}{r}20 \\
\cdot \\
. \\
12 \\
.\end{array}$ & $\begin{array}{l}\text { hoog } \\
\text { erg laag } \\
\text { erg laag } \\
\text { erg laag } \\
\text { gemiddeld } \\
\text { laag }\end{array}$ & $\begin{array}{l}\text { sterk stijgend } \\
\text { - } \\
\text { sterk stijgend } \\
\text { sterk stijgend } \\
\text { sterk dalend }\end{array}$ \\
\hline
\end{tabular}

\section{VERZORGENDE EN DIENSTVERLENENDE BEROEPEN}

Keuken- en serveerpersoneel

Leidinggevenden horeca

Portiers en schoonmaakpersoneel

Kinder-, gezins- en bejaardenverzorgenden

Kappers en schoonheidsspecialisten

$\begin{array}{rll}3 & \text { erg laag } & - \\ 54 & \text { erg hoog } & \text { stijgend } \\ 4 & \text { erg laag } & - \\ 4 & \text { erg laag } & - \\ 45 & \text { erg hoog } & \text { stijgend }\end{array}$

OPENBARE ORDE- EN VEILIGHEIDSBEROEPEN

Politie en beveiligingspersoneel

erg laag

Beroepsmilitairen

erg laag

Bron: ROACBS

- Inclusief personen die werkzaam zijn in het bedrijf of de praktijk van hun partner of ouders en freelancers e.d. 
Tabel 2.8

Belangrijkste bedrijfssectoren per beroepsklasse, gemiddelde $1994-1995^{\circ}$

\begin{tabular}{lll}
\hline Beroepsklasse & $\%$ & trend \\
& $1994-95$
\end{tabular}

Leerkrachten basis- en speciaal onderwijs

Overheid

Andere bedrijfssectoren"

Docenten voortgezet onderwijs

Overheid

Andere bedrijfssectoren

\section{Onderwijskundigen}

Overheid

Kwartaire diensten

Overige commerciële dienstverlening

Andere bedrijfssectoren

Sportdocenten en -instructeurs

Kwartaire diensten

Overheid

Andere bedrijfssectoren

Taalkundigen, tolken en vertalers

Overige commerciële dienstverlening

Andere bedrijfssectoren

53 dalend

Geestelijke verzorgers

Kwartaire diensten

Andere bedrijfssectoren

Fotografen, ontwerpers en vormgevers

Overige commerciële dienstveriening

Handel

Kwartaire diensten

Overige industrie

Andere bedrijfssectoren

$\begin{aligned} 49 & \text { constant } \\ 21 & \text { stijgend } \\ 9 & \text { constant } \\ 8 & \text { sterk stijgend }\end{aligned}$

Regisseurs en kunstenaars

Kwartaire diensten

Overheid

Andere bedrijfssectoren

Uitvoerend agrarisch personeel

Landbouw en visserij

Metaal en elektrotechniek

Overheid dalend

sterk stijgend

sterk stijgend

sterk dalend

sterk stijgend

dalend

sterk stijgend

dalend

sterk stijgend

dalend

constant

sterk stijgend 
Tabel 2.8 (vervolg)

Belangrijkste bedrijfssectoren per beroepsklasse, gemiddelde 1994-1995

\begin{tabular}{lll}
\hline Beroepsklasse & $\%$ & trend \\
& & $1994-95$
\end{tabular}

Kwartaire diensten

sterk stijgend

94 constant

Andere bedrijfssectoren

Bedrijfsleiders in de landbouw

Landbouw en visserij

Andere bedrijfssectoren

Landbouw en milieu-ingenieurs

Diverse bedrijfssectoren -

Heftruckrijders

Handel

Overige industrie

Voedings- en genotmiddelenindustrie

Transport, opslag en communicatie

Metaal en elektrotechniek

Chemie

Andere bedrijissectoren

9

Machinisten bouw en industrie

Bouw

Transport, opslag en communicatie

Landbouw en visserij

Energie

Andere bedrijfssectoren

Ondernemers, uitvoerders en bedrijfskundigen

Overige commerciële dienstverlening

Bouw

Metaal en elektrotechniek

Handel

Kwartaire diensten

Overige industrie

Transport, opslag en communicatie

Overheid

Chemie

Bank- en verzekeringswezen

Voedings- en genotmiddelenindustrie

Andere bedrijfssectoren

Technische en medische vertegenwoordigers

Handel

Andere bedrijfssectoren stijgend

sterk stijgend

constant

stijgend

sterk dalend

sterk dalend

dalend

stijgend

sterk stijgend

dalend

-

constant

dalend

dalend

stijgend

sterk stijgend

sterk dalend

constant

stijgend

sterk stijgend

sterk stijgend

sterk dalend

sterk stijgend

- 
Tabel 2.8 (vervolg)

Belangrijkste bedrijfssectoren per beroepsklasse, gemiddelde 1994-1995

\begin{tabular}{lll}
\hline Beroepsklasse & $\%$ & $\begin{array}{l}\text { trend } \\
1994-95\end{array}$ \\
\hline
\end{tabular}

\section{Technisch tekenaars}

Overige commerciële dienstverlening

Metaal en elektrotechniek

Overheid

Bouw

Andere bedrijfssectoren

\section{Chemo-technici en laboranten}

\section{Chemie}

Overheid

Overige commerciële dienstverlening

Voedings- en genotmiddelenindustrie

Kwartaire diensten

Andere bedrijfssectoren
40 constant

21 stijgend

13 sterk stijgend

10 sterk stijgend

16 -

sterk stijgend

stijgend

stijgend

dalend

10 sterk dalend

Natuurkundigen, technologen en statistici

Overheid

Overige commerciële dienstverlening

Kwartaire diensten

Chemie

Metaal en elektrotechniek

Andere bedrijfssectoren

$\begin{array}{ll}23 & \text { stijgend } \\ 22 & \text { dalend } \\ 15 & \text { sterk dalend } \\ 11 & \text { sterk dalend } \\ 10 & \text { stijgend } \\ 18 & -\end{array}$

Voedings- en genotmiddelenbereiders

Voedings- en genotmiddelenindustrie

Handel

Andere bedrijfssectoren

61 constant

35 constant

Bakkers en chocolademakers

Voedings- en genotmiddelenindustrie

Andere bedrijfssectoren

91 constant

Productiepersoneel textielindustrie

Overige industrie

Andere bedrijfssectoren

dalend

-

\section{Stoffeerders en lederwarenmakers}

\section{Handel}

Metaal en elektrotechniek

Overige industrie

Andere bedrijfssectoren

$\begin{array}{ll}34 & \text { constant } \\ 26 & \text { constant } \\ 18 & \text { sterk stijgend }\end{array}$

Patroonmakers, naaiers en zeilmakers

Overige industrie
53

dalend 
Tabel 2.8 (vervolg)

Belangrijkste bedrijfssectoren per beroepsklasse, gemiddelde 1994-1995

\begin{tabular}{|c|c|c|}
\hline Beroepsklasse & $\%$ & $\begin{array}{l}\text { trend } \\
1994-95\end{array}$ \\
\hline Handel & 21 & sterk dalend \\
\hline Andere bedrijfssectoren & 26 & - \\
\hline \multicolumn{3}{|l|}{ Houtzagers, papier- en kartonmakers } \\
\hline Overige industrie & 84 & constant \\
\hline Andere bedrijfssectoren & 16 & - \\
\hline \multicolumn{3}{|l|}{ Timmerlieden } \\
\hline Bouw & 55 & constant \\
\hline Metaal en elektrotechniek & 18 & dalend \\
\hline Overige industrie & 9 & sterk dalend \\
\hline Handel & 5 & stijgend \\
\hline Kwartaire diensten & 4 & sterk dalend \\
\hline Overheid & 3 & sterk dalend \\
\hline Overige commerciële dienstverlening & 3 & sterk stijgend \\
\hline Andere bedrijfssectoren & 3 & - \\
\hline
\end{tabular}

Productiepersoneel grafische industrie

Overige industrie

Metaal en elektrotechniek

70 constant

Overige commerciële dienstverlening

stijgend

Andere bedrijfssectoren

sterk stijgend

Productiepersoneel chemische industrie

Chemie

Energie

Andere bedrijfssectoren

Vakkrachten metaalindustrie

Metaal en elektrotechniek

Andere bedrijfssectoren

\section{Metaalbewerkers}

Metaal en elektrotechniek

Handel

Andere bedrijfssectoren

Lassers, constructeurs en edelsmeden

Metaal en elektrotechniek

Bouw

Handel

Andere bedrijfssectoren
81 constant

19

dalend

sterk stijgend sterk dalend

stijgend

dalend

sterk stijgend 
Tabel 2.8 (vervolg)

Belangrijkste bedrijfssectoren per beroepsklasse, gemiddelde 1994-1995

\begin{tabular}{lll}
\hline Beroepsklasse & $\%$ & trend \\
& & $1994-95$
\end{tabular}

Machinebank-, plaatwerkers en smeden

$\begin{array}{lrl}\text { Metaal en elektrotechniek } & 60 & \text { stijgend } \\ \text { Handel } & 13 & \text { sterk dalend } \\ \text { Overige commerciële dienstverlening } & 12 & \text { stijgend } \\ \text { Bouw } & 6 & \text { sterk dalend } \\ \text { Andere bedrijfssectoren } & 10 & -\end{array}$

Instrumentmakers en onderhoudsmonteurs

Metaal en elektrotechniek

Handel

Overige industrie

Chemie

Transport, opslag en communicatie

Voedings- en genotmiddelenindustrie

Overige commerciële dienstverlening

Overheid

Energie

Andere bedrijfssectoren

$\begin{aligned} 27 & \text { stijgend } \\ 19 & \text { dalend } \\ 8 & \text { sterk stijgend } \\ 8 & \text { sterk dalend } \\ 8 & \text { sterk dalend } \\ 8 & \text { sterk stijgend } \\ 5 & \text { sterk stijgend } \\ 5 & \text { sterk dalend } \\ 4 & \text { constant } \\ 9 & \text { - }\end{aligned}$

\section{Automonteurs en -herstellers}

Overige commerciële dienstverlening

Transport, opslag en communicatie

Handel

Andere bedrijfssectoren

constant

constant

sterk stijgend

Werktuigbouwkundigen

Metaal en elektrotechniek

Transport, opslag en communicatie

sterk stijgend

Andere bedrijfssectoren

sterk stijgend

\section{Hogere werktuigkundigen}

Metaal en elektrotechniek

Overige commerciële dienstverlening

dalend

Andere bedrijfssectoren

sterk stijgend

Monteurs en controleurs elektrotechnische producten

Metaal en elektrotechniek

constant

Chemie

Overige industrie

sterk stijgend

Andere bedrijfssectoren

sterk stijgend

Monteurs energievoorziening

Diverse bedrijfssectoren 
Tabel 2.8 (vervolg)

Belangrijkste bedrijfssectoren per beroepsklasse, gemiddelde 1994-1995

\begin{tabular}{lll}
\hline Beroepsklasse & $\%$ & trend \\
& & $1994-95$
\end{tabular}

Monteurs en controleurs elektrotechnische installaties

Bouw

$\begin{aligned} 32 & \text { constant } \\ 19 & \text { dalend } \\ 12 & \text { sterk stijgend } \\ 9 & \text { dalend } \\ 7 & \text { sterk stijgend } \\ 6 & \text { sterk stijgend } \\ 5 & \text { sterk dalend }\end{aligned}$

en elektrotechniek

Handel

Transport, opslag en communicatie

Overige commerciële dienstverlening

Kwartaire diensten

Energie

Andere bedrijfssectoren

Elektrotechnische opzichters en uitvoerders

Diverse bedrijfssectoren

Elektrotechnische constructeurs en ingenieurs

Metaal en elektrotechniek

sterk dalend

Andere bedrijfssectoren

Productiepersoneel aardewerk- en glasindustrie

Chemie

Metaal en elektrotechniek

Overige industrie

Overige commerciële dienstverlening

Andere bedrijfssectoren

Metselaars en stukadoors

Bouw

Andere bedrijfssectoren

dalend

Betonwerkers en glaszetters

Boum

Andere bedriifssectoren

dalend

Schilders

Bouw

Andere bedrijfssectoren

constant

Loodgieters en installateurs

Bouw

Metaal en elektrotechniek

Energie

Andere bedrijfssectoren

sterk stijgend sterk dalend sterk stijgend sterk dalend

dalend sterk stijgend sterk stijgend 
Tabel 2.8 (vervolg)

Belangrijkste bedrijfssectoren per beroepsklasse, gemiddelde 1994-1995

\begin{tabular}{lll}
\hline Beroepsklasse & $\%$ & trend \\
& & $1994-95$ \\
\end{tabular}

Wegenbouruvakkrachten en buizenleggers

$\begin{array}{lcl}\text { Bouw } & 47 & \text { constant } \\ \text { Overige commerciële dienstverlening } & 16 & \text { sterk stijgend } \\ \text { Overheid } & 10 & \text { constant } \\ \text { Metaal en elektrotechniek } & 10 & \text { sterk dalend } \\ \text { Transport, opslag en communicatie } & 4 & \text { sterk dalend } \\ \text { Andere bedrijfssectoren } & 13 & -\end{array}$

\section{Bouwkundige projectleiders}

Bouw

Overheid

Overige commerciële dienstverlening

Andere bedrijfssectoren

Architecten en bouwkundige ingenieurs

Overige commerciële dienstverlening

Overheid

Bouw

Andere bedrijfssectoren

\section{Expeditie-medewerkers}

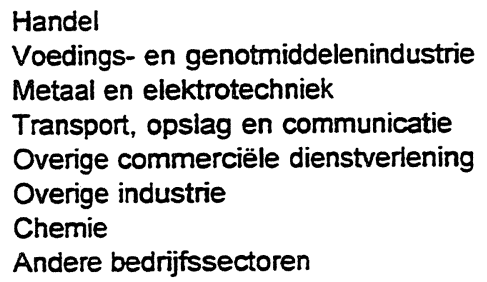

Vissers en jachtopzieners

Diverse bedrijfssectoren

Scheepsdek- en machinekamerpersoneel

Transport, opslag en communicatie Andere bedrijfssectoren

Schippers, officieren en loodsen

Transport, opslag en communicatie

Andere bedrijfssectoren

Chauffeurs en spoorwegpersoneel

Transport, opslag en communicatie Handel dalend

sterk stijgend

dalend

sterk dalend

-

dalend

sterk stijgend

dalend

-

dalend

constant

stijgend

sterk stijgend

sterk stijgend

stijgend

sterk dalend

-

-

-

dalend

sterk stijgend 
Tabel 2.8 (vervolg)

Belangrijkste bedrijfssectoren per beroepsklasse, gemiddelde 1994-1995

\begin{tabular}{l} 
Beroepsklasse \\
\hline Overheid \\
Overige commerciële dienstverlening \\
Voedings- en genotmiddelenindustrie \\
Andere bedrijfssectoren
\end{tabular}

$\% \quad$ trend

1994-'95

Vliegers, verkeersleiders en expediteurs

Transport, opslag en communicatie

Andere bedrijfssectoren

\section{Verpleegkundigen}

Kwartaire diensten

Andere bedrijfssectoren

Leerling-verpleegkundigen, zieken- en kraamverzorgenden

Kwartaire diensten

Andere bedriffssectoren

Dokters-, tandarts- en dierenartsassistenten

Kwartaire diensten

Andere bedrijfssectoren

Opticiens en apothekersassistenten

Handel

Kwartaire diensten

Andere bedrijfssectoren

Paramedische en venwante functies

Kwartaire diensten

Overige commerciële dienstverlening

Overheid

Andere bedrijfssectoren

71

29

98

2

99

98

2

80

18

2

Fysio, arbeids- e.a. bewegingstherapeuten

Kwartaire diensten

Andere bedrijfssectoren

\section{Analisten en laboranten}

Kwartaire diensten

Andere bedrijfssectoren

Artsen, medische specialisten en apothekers

Kwartaire diensten

Overheid
7

6

3

9

1

sterk stijgend

sterk stijgend

sterk dalend

-

stijgend

-

constant

-

constant

-

constant

-

dalend

sterk stijgend

constant

constant

stijgend

-

constant

dalend

87 constant

6 dalend 
Tabel 2.8 (vervolg)

Belangrijkste bedrijfssectoren per beroepsklasse, gemiddelde 1994-1995

\begin{tabular}{lll}
\hline Beroepsklasse & $\%$ & trend \\
& & $1994-95$
\end{tabular}

Andere bedrijfssectoren

\section{Dierenartsen en diergeneeskundigen}

Kwartaire diensten

Andere bedrijfssectoren

\section{Tandheelkundigen}

Kwartaire diensten

100

constant

Hogere leidinggevenden financiën, verkoop e.d.

Kwartaire diensten

Handel

20 constant

Transport, opslag en communicatie

Overige commerciële dienstverlening

Overheid

Metaal en elektrotechniek

Chemie

Bank- en verzekeringswezen

Overige industrie

Voedings- en genotmiddelenindustrie

Andere bedrijfssectoren

Postbestellers en -sorteerders

Transport, opslag en communicatie

Overheid

Andere bedrijfssectoren

\section{Operators en datatypisten}

Overige commerciële dienstverlening

Andere bedrijfssectoren

$27 \quad$ stijgend

73 -

\section{Leidinggevend administratief personeel}

Overheid

Overige commerciële dienstverlening

Kwartaire diensten

Bank- en verzekeringswezen

Andere bedrijfssectoren

\section{Secretaresses en typisten}

Kwartaire diensten

Overige commerciële dienstveriening

Overheid

Handel

Metaal en elektrotechniek

Bank- en verzekeringswezen dalend

dalend

sterk stijgend

stijgend

constant

stijgend

sterk stijgend

sterk dalend

sterk dalend

sterk stijgend

sterk dalend

-

sterk dalend

sterk stijgend

sterk stijgend

sterk stijgend

constant

sterk stijgend

dalend

stijgend

sterk stijgend

dalend 
Tabel 2.8 (vervolg)

Belangrijkste bedrijfssectoren per beroepsklasse, gemiddelde 1994-1995

\begin{tabular}{lll}
\hline Beroepsklasse & $\%$ & trend
\end{tabular}

1994'95

Bouw

Transport, opslag en communicatie

Andere bedrijfssectoren

Bibliotheek- en archiefmedewerkers

Overheid

Kwartaire diensten

Andere bedrijfssectoren

Administrateurs en bankemployés

Bank- en verzekeringswezen

Handel

Overige commerciële dienstveriening

Overheid

Transport, opslag en communicatie

Kwartaire diensten

Bouw

Metaal en elektrotechniek

Andere bedrijfssectoren

Commercieel-administratieve employés

Overheid

Handel

Overige commerciële dienstvertening

Bank- en verzekeringswezen

Transport, opslag en communicatie

Metaal en elektrotechniek

Kwartaire diensten

Bouw

Overige industrie

Andere bedrijfssectoren

Receptionisten, telefonisten en enquêteurs

Transport, opslag en communicatie

Overheid

Overige commerciële dienstverlening

Kwartaire diensten

Handel

Bank- en verzekeringswezen

Andere bedrijfssectoren

Programmeurs en systeemanalisten

Overige commerciële dienstveriening

Overheid

Bank- en verzekeringswezen

Handel

Metaal en elektrotechniek dalend

sterk dalend

3
9

41 stijgend

30 dalend

29

-

dalend

dalend

constant

sterk stijgend

dalend

constant

constant

stijgend

dalend

dalend

sterk stijgend

constant

dalend

constant

constant

stijgend

dalend

sterk stijgend

dalend

stijgend

stijgend

sterk dalend

dalend

stijgend

constant

stijgend

constant

sterk dalend 
Tabel 2.8 (vervolg)

Belangrijkste bedrijfssectoren per beroepsklasse, gemiddelde 1994-1995

\begin{tabular}{lcl}
\hline Beroepsklasse & $\%$ & $\begin{array}{l}\text { trend } \\
1994-' 95\end{array}$ \\
& & \\
Transport, opslag en communicatie & 6 & $\begin{array}{l}\text { sterk dalend } \\
\text { dalend }\end{array}$ \\
Kwartaire diensten & 10 & - \\
Andere bedrijfssectoren & & \\
Economen en accountants & & \\
Overige commerciële dienstverlening & 51 & dalend \\
Overheid & 11 & sterk dalend \\
Bank- en verzekeringswezen & 10 & sterk stijgend \\
Handel & 7 & constant \\
Metaal en elektrotechniek & 4 & sterk stijgend \\
Kwartaire diensten & 4 & sterk stijgend \\
Andere bedrijfssectoren & 14 & - \\
Verkooppersoneel & & \\
Handel & & \\
Overige commerciële dienstverlening & 78 & constant \\
Voedings- en genotmiddelenindustrie & 6 & stijgend \\
Andere bedrijfssectoren & 5 & constant \\
\hline
\end{tabular}

Winkeliers en handelaars

Handel

Overige commerciële dienstverlening

Andere bedrijfssectoren

constant

stijgend

Filiaalhouders, inkopers en vertegenwoordigers

Handel

Bank- en verzekeringswezen

constant

Overige commerciële dienstverlening

Bouw

Metaal en elektrotechniek

Overige industrie

Transport, opslag en communicatie

Voedings- en genotmiddelenindustrie

Overheid

Andere bedrijissectoren

sterk stijgend

sterk stijgend

sterk dalend

sterk dalend

stijgend

constant

sterk stijgend

sterk stijgend

Beleidsmedewerkers en hoofdambtenaren

Overheid

constant

Andere bedrijfssectoren

Advocaten, rechters en notarissen

Overheid

Overige commerciële dienstverlening

41 constant

Andere bedrijfssectoren

stijgend 
Tabel 2.8 (vervolg)

Belangrijkste bedrijfssectoren per beroepsklasse, gemiddelde 1994-1995

\begin{tabular}{lll}
\hline Beroepsklasse & $\%$ & trend \\
$1994-95$ & & \\
& &
\end{tabular}

Journalisten en presentatoren

Overige industrie 29

Kwartaire diensten $\quad 25$

Overheid

Overige commerciële dienstverlening

Andere bedrijfssectoren

Bibliothecarissen en archivarissen

Kwartaire diensten

Overheid

Andere bedrijfssectoren

Arbeidsconsulenten en personeelsdeskundigen

Overige commerciële dienstverlening

Overheid

Kwartaire diensten

Andere bedrijfssectoren

Maatschappelijk werkers

Kwartaire diensten

Overheid

Andere bedrijfssectoren

Sociale wetenschappers

Kwartaire diensten

Overheid

Andere bedrijfssectoren

Huishoudkundige vooriichters

Overheid

Kwartaire diensten

Andere bedrijfssectoren

Keuken- en serveerpersoneel

Overige commerciële dienstverlening

Kwartaire diensten

Overheid

Handel

Andere bedrijfssectoren

Leidinggevenden horeca

Overige commerciële dienstverlening

Kwartaire diensten

Andere bedrijfssectoren sterk dalend sterk stijgend dalend sterk stijgend

-

dalend

sterk stijgend

sterk stijgend sterk dalend sterk dalend

stijgend

dalend

19

-

dalend

sterk stijgend

26

8

-

sterk stijgend sterk stijgend

-

constant constant stijgend stijgend -

dalend stijgend 
Tabel 2.8 (vervolg)

Belangrijkste bedrijfssectoren per beroepsklasse, gemiddelde 1994-1995

\begin{tabular}{lll}
\hline Beroepsklasse & $\%$ & trend \\
& 1994-'95
\end{tabular}

Portiers en schoonmaakpersoneel

Overige commerciële dienstverlening

Kwartaire diensten

Overheid

constant

dalend

Transport, opslag en communicatie

sterk dalend

Metaal en elektrotechniek

sterk dalend

Andere bedrijfssectoren

Kinder-, gezins- en bejaardenverzorgenden

Kwartaire diensten
Overige commerciële dienstveriening
Andere bedrijfssectoren

\section{Kappers en schoonheidsspecialisten}

Overige commerciële dienstverlening

Andere bedrijfssectoren

Politie en beveiligingspersoneel

\section{Overheid}

Overige commerciële dienstverlening

Andere bedrijfssectoren

\section{Beroepsmilitairen}

\section{2 constant}

sterk dalend

-

dalend

5 -

71 stijgend

17 constant

11 -

100

constant

Bron: CBS/ROA

- Een uitgebreidere versie van deze tabel is opgenomen in een aparte uitgave die bij het ROA verkregen kan worden: Verdeeltabellen van bedrijfssectoren, beroepsklassen en opleidingstypen.

- Deze bedrijfssectoren hebben elk een werkgelegenheidsaandeel van minder dan $3 \%$.

- Deze bedrijfssectoren hebben elk minder dan 2.500 werkenden. 
Tabel 2.9

Uitwijkmogelijkheden naar verschillende bedrijfsklassen per beroepsklasse, gemiddelde 1994-1995

\begin{tabular}{ll}
\hline Beroepsklasse & $\begin{array}{l}\text { Gini-Hirschman typering } \\
\text { spreidingsindex }\end{array}$ \\
\hline
\end{tabular}

\section{PEDAGOGISCHE BEROEPEN}

Leerkrachten basis- en speciaal onderwijs

Docenten voortgezet onderwijs

Onderwijskundigen

Sportdocenten en -instructeurs

\section{CULTURELE BEROEPEN}

Taalkundigen, tolken en vertalers

Geestelijke verzorgers

Fotografen, ontwerpers en vormgevers

Regisseurs en kunstenaars

\section{AGRARISCHE BEROEPEN}

Uitvoerend agrarisch personeel

Bedrijfsleiders in de landbouw

Landbouw en milieu-ingenieurs
TECHNISCHE, AMBACHTS- EN INDUSTRIEBEROEPEN

Heftruckrijders

Machinisten bouw en industrie

Ondernemers, uitvoerders en bedrijfskundigen

Technische en medische vertegenwoordigers

Chemo-technici en laboranten

Natuurkundigen, technologen en statistici

Voedings- en genotmiddelenbereiders

Bakkers en chocolademakers

Productiepersoneel textielindustrie

Stoffeerders en lederwarenmakers

Patroonmakers, naaiers en zeilmakers

Houtzagers, papier- en kartonmakers

Timmerlieden

Productiepersoneel grafische industrie

Productiepersoneel chemische industrie

Vakkrachten metaalindustrie

Metaalbewerkers

Lassers, constructeurs en edelsmeden

Machinebank-, plaatwerkers en smeden

Instrumentmakers en onderhoudsmonteurs

Automonteurs en -herstellers

Werktuigbouwkundigen

Monteurs energievoorziening

gemiddeld

erg laag gemiddeld erg hoog

gemiddeld

erg hoog

gemiddeld gemiddeld

hoog

erg hoog

gemiddeld

erg laag

gemiddeld

gemiddeld

gemiddeld

laag

gemiddeld

gemiddeld

gemiddeld

gemiddeld

hoog

gemiddeld

hoog

erg hoog

laag

erg hoog

hoog

erg hoog

gemiddeld

hoog

hoog

erg hoog

hoog 
Tabel 2.9 (vervolg)

Uitwijkmogelijkheden naar verschillende bedrijfsklassen per beroepsklasse, gemiddelde 1994-1995

Beroepsklasse Gini-Hirschman typering

spreidingsindex

Metselaars en stukadoors

0,17

Betonwerkers en glaszetters

0,22

0,26

Schilders

Loodgieters en installateurs

Wegenbouwvakkrachten en buizenleggers

0,42

0,76

Bouwkundige projectleiders

0,80

0,73

typering

Architecten en bouwkundige ingenieurs

erg laag

TRANSPORTBEROEPEN

Expeditie-medewerkers

Vissers en jachtopzieners

Scheepsdek- en machinekamerpersoneel

Schippers, officieren en loodsen

Chauffeurs en spoorwegpersoneel

Vliegers, verkeersleiders en expediteurs

laag

laag

gemiddeld

gemiddeld

gemiddeld

\section{MEDISCHE EN PARAMEDISCHE BEROEPEN}

Verpleegkundigen

Dokters-, tandarts- en dierenartsassistenten

Opticiens en apothekersassistenten

Paramedische en verwante functies

Fysio, arbeids- e.a. bewegingstherapeuten

Analisten en laboranten

Artsen, medische specialisten en apothekers

Dierenartsen en diergeneeskundigen

\section{ECONOMISCH-ADMINISTRATIEVE BEROEPEN}

Hogere leidinggevenden financiën, verkoop e.d.

Postbestellers en -sorteerders

Leidinggevend administratief personeel

Secretaresses en typisten

Bibliotheek- en archiefmedewerkers

Administrateurs en bankemployés

Commercieel-administratieve employés

Receptionisten, telefonisten en enquêteurs

Programmeurs en systeemanalisten

Economen en accountants

Winkeliers en handelaars

Filiaalhouders, inkopers en vertegenwoordigers

Beleidsmedewerkers en hoofdambtenaren

Advocaten, rechters en notarissen

\section{SOCIAAL-CULTURELE BEROEPEN}


Tabel 2.9 (vervolg)

Uitwijkmogelijkheden naar verschillende bedrijfsklassen per beroepsklasse, gemiddelde 1994-1995

\begin{tabular}{|c|c|c|}
\hline Beroepsklasse & $\begin{array}{l}\text { Gini-Hirschman } \\
\text { spreidingsindex }\end{array}$ & typering \\
\hline $\begin{array}{l}\text { Bibliothecarissen en archivarissen } \\
\text { Arbeidsconsulenten en personeelsdeskundigen } \\
\text { Maatschappelijk werkers } \\
\text { Sociale wetenschappers } \\
\text { Huishoudkundige voorlichters }\end{array}$ & $\begin{array}{l}0,85 \\
0,80 \\
0,42 \\
0,61 \\
0,84\end{array}$ & $\begin{array}{l}\text { gemiddeld } \\
\text { gemiddeld } \\
\text { laag } \\
\text { gemiddeld } \\
\text { gemiddeld }\end{array}$ \\
\hline \multicolumn{3}{|c|}{ VERZORGENDE EN DIENSTVERLENENDE BEROEPEN } \\
\hline $\begin{array}{l}\text { Keuken- en serveerpersoneel } \\
\text { Leidinggevenden horeca } \\
\text { Portiers en schoonmaakpersoneel } \\
\text { Kinder-, gezins- en bejaardenverzorgenden } \\
\text { Kappers en schoonheidsspecialisten }\end{array}$ & $\begin{array}{l}0,62 \\
0,47 \\
0,87 \\
0,13 \\
0,08\end{array}$ & $\begin{array}{l}\text { gemiddeld } \\
\text { laag } \\
\text { hoog } \\
\text { erg laag } \\
\text { erg laag }\end{array}$ \\
\hline \multicolumn{3}{|l|}{ OPENBARE ORDE- EN VEILIGHEIDSBEROEPEN } \\
\hline $\begin{array}{l}\text { Politie en beveiligingspersoneel } \\
\text { Beroepsmilitairen }\end{array}$ & $\begin{array}{l}0,47 \\
0,01\end{array}$ & $\begin{array}{l}\text { laag } \\
\text { erg laag }\end{array}$ \\
\hline
\end{tabular}

Bron: ROA 
Tabel 2.10

Belangrijkste opleidingstypen per beroepsklasse, gemiddelde $1994-1995^{\circ}$

trend

1993-'95

Leerkrachten basis- en speciaal onderwijs

$\mathrm{HBO}$ onderwijs

Andere opleidingstypen

Docenten voortgezet onderwijs

HBO onderwijs

WO letteren

WO wiskunde en natuurwetenschappen

WO sociaal-cultureel

Andere opleidingstypen

$\%$

\section{Onderwijskundigen}

HBO onderwijs

WO sociaal-cultureel

HBO sociaal-cultureel

Andere opleidingstypen

constant

stijgend

sterk stijgend

sterk dalend

Sportdocenten en -instructeurs

Diverse opleidingstypen ${ }^{-}$

Taalkundigen, tolken en vertalers

Wo letteren

Andere opleidingstypen

Geestelijke verzorgers

WO theologisch

Andere opleidingstypen

Fotografen, ontwerpers en vormgevers

HBO kunst

MBO/LLW grafische techniek

HAVONWO bovenbouw

Andere opleidingstypen

Regisseurs en kunstenaars
HBO kunst
$\mathrm{HBO}$ onderwijs
Andere opleidingstypen

Uitvoerend agrarisch personeel

MBO/LLW landbouw en natuurlijke omgeving

Basisonderwijs

VBO landbouw en natuurlijke omgeving 
Tabel 2.10 (vervolg)

Belangrijkste opleidingstypen per beroepsklasse, gemiddelde 1994-1995

\begin{tabular}{l} 
Beroepsklasse \\
\hline MAVO, onderbouw HAVONWO \\
VBO verzorging \\
VBO mechanische techniek \\
Andere opleidingstypen
\end{tabular}

$\% \quad$ trend

1993-'95

Bedrijfsleiders in de landbounw

MBO/LLW landbouw en natuurlijke omgeving

VBO landbouw en natuurlijke omgeving

Basisonderwijs

MBO/LLW handel

VBO verzorging

MAVO, onderbouw HAVOMWO

Andere opleidingstypen

8

7

3

23

Landbouw en milieu-ingenieurs

Diverse opleidingstypen

100

Heftruckrijders

Basisonderwijs

MAVO, onderbouw HAVOMWO

Andere opleidingstypen

Machinisten bouw en industrie

Basisonderwijs

MBO/LLW werktuigbouwkunde

VBO mechanische techniek

Andere opleidingstypen

Ondernemers, uitvoerders en bedrijfskundigen

\author{
MBO/LLW bouwkunde \\ MBORLW handel \\ MBORLW elektrotechniek \\ Basisonderwijs \\ HAVONWO bovenbouw \\ MBO/LLW werktuigbouwkunde \\ MAVO, onderbouw HAVOMWO \\ Andere opleidingstypen
}

Technische en medische vertegenwoordigers

Diverse opleidingstypen

Technisch tekenaars

MBO/LLW bouwkunde

MBO/LLW werktuigbouwkunde

MBO/LLW elektrotechniek

sterk stijgend

-

$-$

32

22

16

10

52

41

22

8

5

3

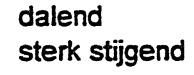

dalend

-

$-$

-$$
\text { - }
$$$$
\text { sterk dalend }
$stijgend

-

dalend

-

dalend

- 
Tabel 2.10 (vervolg)

Belangrijkste opleidingstypen per beroepsklasse, gemiddelde 1994-1995

\begin{tabular}{lrc}
\hline Beroepsklasse & $\%$ & $\begin{array}{l}\text { trend } \\
1993-95\end{array}$ \\
\hline HBO (weg- en water)bouwkunde & 11 & sterk stijgend \\
MBO/LW weg- en waterbouwkunde & 8 & - \\
Andere opleidingstypen & 35 & -
\end{tabular}

Chemo-technici en laboranten

HBO technisch laboratorium

MBO technisch laboratorium

Andere opleidingstypen

$\begin{array}{ll}31 & - \\ 19 & \text { sterk dalend } \\ 50 & -\end{array}$

Natuurkundigen, technologen en statistici

WO wiskunde en natuurwetenschappen

HBO technisch laboratorium

Andere opleidingstypen

$\begin{aligned} 18 & - \\ 4 & -\end{aligned}$

Voedings- en genotmiddelenbereiders

Basisonderwijs

MBO/LLW consumptieve techniek

MAVO, onderbouw HAVOMWO

Andere opleidingstypen

Bakkers en chocolademakers

MBO/LLW consumptieve techniek

VBO consumptieve techniek

Basisonderwijs

Andere opleidingstypen 
Tabe/ 2.10 (vervolg)

Belangrijkste opleidingstypen per beroepsklasse, gemiddelde 1994-1995

\begin{tabular}{lll}
\hline Beroepsklasse & $\%$ & trend \\
$1993-95$
\end{tabular}

\section{Timmerlieden}

MBO/LLW bouwkunde

VBO bouwtechniek

Basisonderwijs

Andere opleidingstypen

$\begin{array}{ll}35 & \text { stijgend } \\ 29 & \text { dalend } \\ 10 & \text { sterk dalend }\end{array}$

Productiepersoneel grafische industrie

MBO/LLW grafische techniek

Basisonderwijs

VBO grafische techniek

MAVO, onderbouw HAVOMWO

Andere opleidingstypen

Productiepersoneel chemische industrie

MBO/LLW procestechniek

Basisonderwijs

Andere opleidingstypen

stijgend

sterk stijgend

dalend

sterk dalend

Vakkrachten metaalindustrie

Basisonderwijs

Andere opleidingstypen

dalend

Metaalbewerkers

Basisonderwijs

VBO mechanische techniek

MBO/LLW metaalkunde

MAVO, onderbouw HAVONWO

Andere opleidingstypen

constant

sterk dalend

Lassers, constructeurs en edelsmeden

VBO mechanische techniek

sterk dalend

MBO/LWW metaalkunde

Basisonderwijs

MBO/LLW werktuigbouwkunde

Andere opleidingstypen

sterk stijgend

sterk stijgend

Machinebank-, plaatwerkers en smeden

VBO mechanische techniek

dalend

MBO/LLW metaalkunde

MBO/LWW werktuigbouwkunde

Basisonderwijs

MBO/LLW elektrotechniek

MBO/LWW motorvoertuigentechniek

Andere opleidingstypen

dalend

sterk stijgend

sterk dalend

stijgend 
Tabel 2.10 (vervolg)

Belangrijkste opleidingstypen per beroepsklasse, gemiddelde 1994-1995

\begin{tabular}{lll}
\hline Beroepsklasse & $\%$ & trend \\
$1993-95$
\end{tabular}

Instrumentmakers en onderhoudsmonteurs

$\begin{array}{lcc}\text { MBO/LWW werktuigbouwkunde } & 17 & - \\ \text { MBO/LW elektrotechniek } & 14 & - \\ \text { VBO mechanische techniek } & 11 & \text { sterk dalend } \\ \text { MBO/LW metaalkunde } & 9 & - \\ \text { Basisonderwijs } & 8 & \text { sterk stijgend } \\ \text { VBO elektrotechniek } & 4 & - \\ \text { MBO/LW motorvoertuigentechniek } & 4 & \text { sterk dalend } \\ \text { Andere opleidingstypen } & 34 & -\end{array}$

Automonteurs en -herstellers

MBO/LLW motorvoertuigentechniek

VBO motorvoertuigentechniek

Basisonderwijs

Andere opleidingstypen

sterk dalend

Werktuigbouwkundigen

MBO/LWW werktuigbouwkunde

Andere opleidingstypen

Hogere werktuigkundigen

HBO werktuigbouwkunde

MBO/LLW werktuigbouwkunde

Andere opleidingstypen

Monteurs en controleurs elektrotechnische producten

\author{
Basisondenwijs \\ MAVO, onderbouw HAVONWO \\ VBO verzorging \\ Andere opleidingstypen
}

Monteurs energievoorziening

Diverse opleidingstypen

Monteurs en controleurs elektrotechnische installaties

MBO/LLW elektrotechniek

VBO elektrotechniek

Basisonderwijs

MAVO, onderbouw HAVOMWO

Andere opleidingstypen

Elektrotechnische opzichters en uitvoerders

MBO/LLW elektrotechniek

Andere opleidingstypen stijgend

sterk stijgend

stijgend

sterk dalend

-

- 
Tabel 2.10 (vervolg)

Belangrijkste opleidingstypen per beroepsklasse, gemiddelde 1994-1995

\begin{tabular}{lll}
\hline Beroepsklasse & $\%$ & trend \\
& $1993-95$
\end{tabular}

Elektrotechnische constructeurs en ingenieurs

HBO elektrotechniek en technische informatica

MBO/LLW elektrotechniek

dalend

Andere opleidingstypen

Productiepersoneel aardewerk- en glasindustrie

Basisonderwijs

MAVO, onderbouw HAVOMWO

VBO bouwtechniek

VBO mechanische techniek

Andere opleidingstypen

Metselaars en stukadoors

VBO bouwtechniek

Basisondenwijs

MBO/LLW bouwkunde

Andere opleidingstypen

dalend

sterk stijgend

sterk stijgend sterk dalend

Betonwerkers en glaszetters

Basisonderwijs

VBO bouwtechniek

MBO/LLW bouwkunde

Andere opleidingstypen

Schilders

MBORLW bouwkunde

VBO bouwtechniek

Basisonderwijs

Andere opleidingstypen

Loodgieters en installateurs

MBO/LLW bouwkunde

VBO mechanische techniek

Basisondenwijs

VBO installatietechniek

MBORLW werktuigbouwkunde

Andere opleidingstypen

sterk dalend

sterk stijgend

Wegenbouwvakkrachten en buizenleggers

Basisonderwijs

VBO bouwtechniek

VBO mechanische techniek

MAVO, onderbouw HAVONWO

VBO landbouw en natuurlijke omgeving

MBO/LLW bouwkunde

dalend

sterk dalend

-

dalend

dalend

sterk dalend

sterk stijgend 
Tabel 2.10 (vervolg)

Belangrijkste opleidingstypen per beroepsklasse, gemiddelde 1994-1995

\begin{tabular}{lll}
\hline Beroepsklasse & $\%$ & trend \\
& & $1993-95$
\end{tabular}

Andere opleidingstypen

\title{
Bouwkundige projectleiders
}

MBOLLLW bouwkunde

HBO (weg-en water)bouwkunde

MBO/LLW weg-en waterbouwkunde

Andere opleidingstypen

Architecten en bouwkundige ingenieurs

HBO (weg-en water)bouwkunde

WO (weg- en water)bouwkunde

MBO/LLW bouwkunde

Andere opleidingstypen

\section{Expeditie-medewerkers}

\author{
Basisonderwijs \\ MAVO, onderbouw HAVONWO \\ VBO verzorging \\ MBO/LLW handel \\ VBO bouwtechniek \\ HAVONWO bovenbouw \\ VBO mechanische techniek \\ Andere opleidingstypen
}

Vissers en jachtopzieners

Diverse opleidingstypen

Scheepsdek- en machinekamerpersoneel

Diverse opleidingstypen

Schippers, officieren en loodsen

MBO/LLW haven en vervoer

HBO haven en vervoer

Andere opleidingstypen

37

36

27

Chauffeurs en spoorwegpersoneel

Basisonderwijs

VBO haven en vervoer

MAVO, onderbouw HAVONWO

MBO/LLW haven en vervoer

VBO mechanische techniek

$M B O / L L W$ hande

VBO motorvoertuigentechniek

VBO bouwtechniek

Andere opleidingstypen sterk dalend

-

sterk dalend

sterk dalend

-

dalend

constant

-

sterk stijgend

-

sterk dalend

sterk stijgend

-

stijgend

-

sterk dalend

dalend

stijgend

sterk dalend

sterk dalend 
Tabel 2.10 (vervolg)

Belangrijkste opleidingstypen per beroepsklasse, gemiddelde 1994-1995

\begin{tabular}{lll}
\hline Beroepsklasse & $\%$ & trend \\
$1993-95$
\end{tabular}

Vliegers, verkeersleiders en expediteurs

HBO haven en vervoer

Basisonderwijs

Andere opleidingstypen

Verpleegkundigen

MBO/LLW verpleging en medische assistentie $H B O$ verpleging en paramedisch

Andere opleidingstypen

59 constant

Leerling-verpleegkundigen, zieken- en kraamverzorgenden

\author{
MBO/LLW verpleging en medische assistentie \\ MBO/LLW verzorging \\ MBO sociaal-cultureel \\ MAVO, Onderbouw HAVONWO \\ HAVONWO bovenbouw \\ HBO sociaal-cultureel \\ VBO verzorging \\ Andere opleidingstypen
}

constant

Dokters-, tandarts- en dierenartsassistenten

MBO/LLW verpleging en medische assistentie Andere opleidingstypen

Opticiens en apothekersassistenten

MBO/LLW medisch laboratorium

Paramedische en verwante functies

$H B O$ verpleging en paramedisch MBO/LLW verpleging en medische assistentie Andere opleidingstypen

Fysio, arbeids- e.a. bewegingstherapeuten

HBO verpleging en paramedisch

Analisten en laboranten

HBO medisch laboratorium

HBO technisch laboratorium MBO/LLW medisch laboratorium 
Tabel 2.10 (vervolg)

Belangrijkste opleidingstypen per beroepsklasse, gemiddelde 1994-1995

\begin{tabular}{lll}
\hline Beroepsklasse & $\%$ & $\begin{array}{l}\text { trend } \\
1993-' 95\end{array}$ \\
& \\
\hline
\end{tabular}

Artsen, medische specialisten en apothekers

WO dier-, genees- en tandheelkunde

$87 \quad$ stijgend

Andere opleidingstypen

13 -

Dierenartsen en diergeneeskundigen

WO dier-, genees- en tandheelkunde

Andere opleidingstypen

95 constant

Tandheelkundigen

WO dier-, genees- en tandheelkunde

Andere opleidingstypen

Hogere leidinggevenden financiën, verkoop e.d.

HBO sociaal-cultureel

HAVONWO bovenbouW

MAVO, onderbouw HAVOMWO

MBO/LLW administratief

WO econom(etr)ie en accountancy

MBO/LLW handel

HBO accountancy

Andere opleidingstypen

Postbestellers en -sorteerders

Basisonderwijs
MAVO, onderbouw HAVOMWO
VBO verzorging
Andere opleidingstypen

Operators en datatypisten

Diverse opleidingstypen

Leidinggevend administratief personeel

Diverse opleidingstypen

Secretaresses en typisten

MBO/LLW secretariee

HAVONWO bovenbouw

MAVO, onderbouw HAVOMWO

MBO/LLW hande

$M B O / L L W$ verpleging en medische assistentie

Andere opleidingstypen
20 stijgend

sterk dalend sterk stijgend sterk dalend sterk dalend

-

sterk dalend dalend

sterk stijgend sterk dalend

stijgend 
Tabel 2.10 (vervolg)

Belangrijkste opleidingstypen per beroepsklasse, gemiddelde 1994-1995

\begin{tabular}{lll}
\hline Beroepsklasse & $\%$ & trend \\
$1993-95$
\end{tabular}

Bibliotheek- en archiefmedewerkers

MBO sociaal-cultureel

MAVO, onderbouw HAVOMWO

Andere opleidingstypen

Administrateurs en bankemployés

MAVO, onderbouw HAVOMWO

MBO/LW administratief

HAVONWO bovenbouw

MBO/LLW handel

MBO bestuurlijk-juridisch

VBO verzorging

VBO administratie

MBO/LLW secretarieel

Basisonderwijs

Andere opleidingstypen

Commercieel-administratieve employés

MAVO, onderbouW HAVOMWO

HAVONWO bovenbouw

MBO/LLW handel

Basisondenwijs

MBO/LLW secretarieel

MBO bestuurlijk-juridisch

MBO/LLW administratief

Andere opleidingstypen

Receptionisten, telefonisten en enquêteurs

MAVO, onderbouw HAVONWO

HAVONWO bovenbouw

MBO/LLW handel

MBO/LLW secretarieel

MBO toerisme en recreatie

Basisondenwijs

VBO verzorging

MBO/LLW verzorging

Andere opleidingstypen

Programmeurs en systeemanalisten

HBO bedrijfsinformatica

HAVONWO bovenbouw

$\mathrm{HBO}$ elektrotechniek en technische informatica

MBO/LLW elektrotechniek

MAVO, onderbouw HAVONWO

Andere opleidingstypen sterk dalend

constant

constant

sterk stijgend

sterk dalend

stijgend

-

dalend

dalend

constant

stijgend

dalend

-

$-$

sterk dalend

sterk stijgend

sterk dalend

stijgend

sterk stijgend

sterk dalend stijgend

sterk stijgend

stijgend 
Tabel 2.10 (vervolg)

Belangrijkste opleidingstypen per beroepsklasse, gemiddelde 1994-1995

\begin{tabular}{lll}
\hline Beroepsklasse & $\%$ & trend \\
1993-95
\end{tabular}

Economen en accountants

WO econom(etr)ie en accountancy

1993-'95

HBO accountancy

HAVOMWO bovenbouw

MBO/LLW administratief

HBO bestuurlijk-juridisch

WO bestuurlijk

Andere opleidingstypen

\section{Verkooppersoneel}

MBO/LLW handel

MAVO, onderbouw HAVOMWO

VBO verzorging

Basisonderwijs

HAVONWO bovenbouw

MBO/LLW verzorging

Andere opleidingstypen

dalend

sterk dalend

sterk stijgend

dalend

constant

dalend

sterk stijgend

$-$

Winkeliers en handelaars

MBO/LLW handel

MAVO, onderbouw HAVONWO

Basisonderwijs

HAVOMWO bovenbour

Andere opleidingstypen

Filiaalhouders, inkopers en vertegenwoordigers

MBO/LLW handel

MAVO, onderbouw HAVOMWO

HAVONWO bovenbouw

MBO/LLW commercieel

HBO commerciële economie

Basisonderwijs

Andere opleidingstypen

Beleidsmedewerkers en hoofdambtenaren

HBO bestuurlijk-juridisch

WO juridisch

WO sociaal-cultureel

Andere opleidingstypen

9

sterk dalend

sterk dalend

sterk stijgend

sterk stijgend

stijgend

dalend

Advocaten, rechters en notarissen

WO juridisch

Andere opleidingstypen

70 dalend 
Tabel 2.10 (vervolg)

Belangrijkste opleidingstypen per beroepsklasse, gemiddelde 1994-1995

\begin{tabular}{lll}
\hline Beroepsklasse & $\%$ & trend
\end{tabular}

Journalisten en presentatoren

$\begin{array}{lcl}\text { HBO sociaal-cultureel } & 13 & \text { stijgend } \\ \text { HAVOMWO bovenbouw } & 13 & \text { sterk dalend } \\ \text { WO letteren } & 12 & \text { sterk stijgend } \\ \text { WO sociaal-cultureel } & 6 & - \\ \text { Andere opleidingstypen } & 57 & -\end{array}$

Bibliothecarissen en archivarissen

HBO sociaal-cultureel

constant

Andere opleidingstypen

Arbeidsconsulenten en personeelsdeskundigen

HBO sociaal-cultureel

MBO sociaal-cultureel

HAVONWO bovenbouw

Andere opleidingstypen

dalend

aatschappelijk werkers

HBO sociaal-cultureel

WO sociaal-cultureel

MBO sociaal-cultureel

MBO/LLW verpleging en medische assistentie

HBO onderwijs

MBO/LLW verzorging

Andere opleidingstypen

sterk stijgend

dalend

sterk stijgend

-

Sociale wetenschappers

WO sociaat-cultureel

HBO sociaal-cultureel

Andere opleidingstypen

dalend

-

Huishoudkundige voorlichters

Diverse opleidingstypen

Keuken- en serveerpersoneel

MBO/LLW verzorging

Basisonderwijs

VBO verzorging

MAVO, onderbouw HAVOMWO

HAVONWO bovenbouw

MBORLW horeca en uiterlijke verzorging

Andere opleidingstypen

stijgend

sterk dalend

constant

$-$ 
Tabel 2.10 (vervolg)

Belangrijkste opleidingstypen per beroepsklasse, gemiddelde 1994-1995

\begin{tabular}{lll}
\hline Beroepsklasse & $\%$ & trend
\end{tabular}

1993-95

\section{Leidinggevenden horeca}

MBO/LLW horeca en uiterlijke verzorging

Basisonderwijs

MBO/LLW verzorging

VBO verzorging

MAVO, onderbouW HAVOMWO

MBO/LLW handel

HAVOMWO bovenbouw

Andere opleidingstypen

sterk stijgend

sterk dalend

dalend

dalend

sterk stijgend

Portiers en schoonmaakpersoneel

Basisonderwijs
VBO verzorging
MAVO, onderbouw HAVOMWO
MBO/LLW verzorging
HAVONWO bovenbouw
MBO/LLW handel
Andere opleidingstypen

dalend

stijgend

-

$-$

Kinder-, gezins- en bejaardenverzorgenden

MBO/LLW verzorging

VBO verzorging

Basisonderwijs

MAVO, onderbouw HAVONWO

MBO sociaal-cultureel

MBO/LLW verpleging en medische assistentie

HBO sociaal-cultureel

Andere opleidingstypen

41

11

9

5

5

4

18

Kappers en schoonheidsspecialisten

MBO/LLW verzorging

MBOLLWW horeca en uiterlijke verzorging

Andere opleidingstypen

Politie en beveiligingspersoneel

MBO politie en defensie

VBO bewaking

MAVO, onderbouw HAVOMWO

Basisonderwijs

Andere opleidingstypen

49

10

5

32

Beroepsmilitairen

MBO politie en defensie
39 
Tabel 2.10 (vervolg)

Belangrijkste opleidingstypen per beroepsklasse, gemiddelde 1994-1995

\begin{tabular}{lrl}
\hline Beroepsklasse & $\%$ & $\begin{array}{l}\text { trend } \\
1993-95\end{array}$ \\
\hline MAVO, onderbouw HAVOMWO & 11 & sterk stijgend \\
HBO politie en defensie & 9 & sterk dalend \\
Andere opleidingstypen & 41 & - \\
\hline
\end{tabular}

\section{Bron: CBS/ROA}

- Een uitgebreidere versie van deze tabel is opgenomen in een aparte uitgave die bij het ROA verkregen kan worden: Verdeeltabellen van bedrijfssectoren, beroepsklassen en opleidingstypen.

- Deze opleidingstypen hebben elk een werkgelegenheidsaandeel van minder dan $3 \%$.

- Deze opleidingstypen hebben elk minder dan 2.500 werkenden. 
Tabel 2.11

Substitutiemogelijkheden tussen mensen met uiteenlopende opleidingsachtergronden per beroepsklasse, gemiddelde 1994-1995

\begin{tabular}{llr}
\hline Beroepsklasse & $\begin{array}{l}\text { Gini-Hirschman } \\
\text { spreidingsindex }\end{array}$ & typering
\end{tabular}

\section{PEDAGOGISCHE BEROEPEN}

Leerkrachten basis- en speciaal onderwijs

Docenten voortgezet onderwijs

Onderwijskundigen

Sportdocenten en -instructeurs

\section{CULTURELE BEROEPEN}

Taalkundigen, tolken en vertalers

Geestelijke verzorgers

Fotografen, ontwerpers en vormgevers

Regisseurs en kunstenaars

\section{AGRARISCHE BEROEPEN}

Uitvoerend agrarisch personeel

Bedrijfsleiders in de landbouw

Landbouw en milieu-ingenieurs

TECHNISCHE, AMBACHTS- EN INDUSTRIEBEROEPEN

\section{Heftruckrijders}

Machinisten bouw en industrie

Ondememers, uitvoerders en bedrijfskundigen

Technische en medische vertegenwoordigers

Technisch tekenaars

Chemo-technici en laboranten

Natuurkundigen, technologen en statistici

Voedings- en genotmiddelenbereiders

Bakkers en chocolademakers

Productiepersoneel textielindustrie

Stoffeerders en lederwarenmakers

Patroonmakers, naaiers en zeilmakers

Houtzagers, papier- en kartonmakers

Timmerlieden

Productiepersoneel grafische industrie

Productiepersoneel chemische industrie

Vakkrachten metaalindustrie

Metaalbewerkers

Lassers, constructeurs en edelsmeden

Machinebank-, plaatwerkers en smeden

Instrumentmakers en onderhoudsmonteurs

Automonteurs en -herstellers

Werktuigbouwkundigen

Hogere werktuigkundigen

Monteurs en controleurs elektrotechnische producten

Monteurs energievoorziening

Monteurs en controleurs elektrotechnische installaties

Elektrotechnische opzichters en uitvoerders

Elektrotechnische constructeurs en ingenieurs

$\begin{array}{ll}0,35 & \text { erg laag } \\ 0,95 & \text { hoog } \\ 0,93 & \text { hoog } \\ 0,93 & \text { hoog }\end{array}$

0,83

0,64

0,90

0,78

gemiddeld

laag

gemiddeld

laag

$\begin{array}{ll}0,93 & \text { hoog } \\ 0,94 & \text { hoog } \\ 0,82 & \text { gemiddeld }\end{array}$

gemiddeld gemiddeld

erg hoog

erg hoog

gemiddeld

gemiddeld

hoog

gemiddeld

laag

gemiddeld

gemiddeld

gemiddeld

hoog

laag

gemiddeld

hoog

hoog

hoog

gemiddeld

hoog

hoog

laag

hoog

gemiddeld

gemiddeld

laag

laag

laag

gemiddeld 
Tabel 2.11 (vervolg)

Substitutiemogelijkheden tussen mensen met uiteenlopende opleidingsachtergronden per beroepsklasse, gemiddelde 1994-1995

Gini-Hirschman spreidingsindex

Productiepersoneel aardewerk- en glasindustrie

Metselaars en stukadoors

Betonwerkers en glaszetters

Schilders

Loodgieters en installateurs

Wegenbouwvakkrachten en buizenleggers

Bouwkundige projectleiders

Architecten en bouwkundige ingenieurs

\title{
TRANSPORTBEROEPEN
}

Expeditie-medewerkers

Vissers en jachtopzieners

Scheepsdek- en machinekamerpersoneel

Schippers, officieren en loodsen

Chauffeurs en spoorwegpersoneel

Vliegers, verkeersleiders en expediteurs

\section{MEDISCHE EN PARAMEDISCHE BEROEPEN}

\author{
Verpleegkundigen \\ Leerling-verpleegkundigen, zieken- en kraamverzorgenden \\ Dokters-, tandarts- en dierenartsassistenten \\ Opticiens en apothekersassistenten \\ Paramedische en verwante functies \\ Fysio, arbeids- e.a. bewegingstherapeuten \\ Analisten en laboranten \\ Artsen, medische specialisten en apothekers \\ Dierenartsen en diergeneeskundigen
}

Tandheelkundigen

0,89

0,77

0,87

0,71

0,92

0,90

0,88

0,81

0,88

0,87

0,86

0,86

0,85

\section{ECONOMISCH-ADMINISTRATIEVE BEROEPEN}

Hogere leidinggevenden financiën, verkoop e.d.

Postbestellers en -sorteerders

Operators en datatypisten

Leidinggevend administratief personeel

Secretaresses en typisten

Bibliotheek- en archiefmedewerkers

Administrateurs en bankemployés

Commercieel-administratieve employés

Receptionisten, telefonisten en enquêteurs

Programmeurs en systeemanalisten

Economen en accountants

Verkooppersoneel

Winkeliers en handelaars

Filiaalhouders, inkopers en vertegenwoordigers

Beleidsmedewerkers en hoofdambtenaren

Advocaten, rechters en notarissen

gemiddeld gemiddeld gemiddeld laag gemiddeld gemidield gemiddeld gemiddeld

gemiddeld
laag
gemiddeld
laag
hoog
gemiddeld

erg laag

laag

laag erg laag gemiddeld erg laag gemiddeld erg laag erg laag erg laag

erg hoog gemiddeld hoog

hoog

hoog

hoog

hoog

hoog

hoog gemiddeld hoog erg hoog erg laag 
Tabel 2.11 (vervolg)

Substitutiemogelijkheden tussen mensen met uiteenlopende opleidingsachtergronden per beroepsklasse, gemiddelde 1994-1995

Beroepsklasse

Gini-Hirschman

typering

spreidingsindex

SOCIAAL-CULTURELE BEROEPEN

Journalisten en presentatoren

Bibliothecarissen en archivarissen

Arbeidsconsulenten en personeelsdeskundigen

Maatschappelijk werkers

Sociale wetenschappers

Huishoudkundige voorlichters

$\begin{array}{ll}0,95 & \text { hoog } \\ 0,77 & \text { laag } \\ 0,90 & \text { gemiddeld } \\ 0,84 & \text { gemiddeld } \\ 0,89 & \text { gemiddeld } \\ 0,95 & \text { hoog }\end{array}$

VERZORGENDE EN DIENSTVERLENENDE BEROEPEN

\begin{tabular}{lll} 
Keuken- en serveerpersoneel & 0,91 & hoog \\
Leidinggevenden horeca & 0,92 & hoog \\
Portiers en schoonmaakpersoneel & 0,87 & $\begin{array}{l}\text { gemiddeld } \\
\text { gemiddeld } \\
\text { Kinder-, gezins- en bejaardenverzorgenden } \\
\text { Kappers en schoonheidsspecialisten }\end{array}$ \\
laag \\
OPENBARE ORDE- EN VEILIGHEIDSBEROEPEN & 0,87 & \\
Politie en beveiligingspersoneel & 0,65 & \\
BeroepSmilitairen & & laag \\
\hline
\end{tabular}

Bron: ROA 
Tabel 2.12

Conjunctuurgevoeligheid per beroepsklasse

Beroepsklasse conjunctuurgevoeligheid typering

\section{PEDAGOGISCHE BEROEPEN}

Leerkrachten basis- en speciaal onderwijs $\quad 0,47$

Docenten voortgezet onderwijs $\quad 1,07$

0,46

Sportdocenten en -instructeurs

CULTURELE BEROEPEN

Taalkundigen, tolken en vertalers

Geestelijke verzorgers

\section{AGRARISCHE BEROEPEN}

Uitvoerend agrarisch personeel

\section{TECHNISCHE, AMBACHTS- EN INDUSTRIEBEROEPEN}

Heftruckrijders

Machinisten bouw en industrie

Ondernemers, uitvoerders en bedrijfskundigen

Technische en medische vertegenwoordigers

Technisch tekenaars

Chemo-technici en laboranten

Natuurkundigen, technologen en statistici

Voedings- en genotmiddelenbereiders

Bakkers en chocolademakers

Productiepersoneel textielindustrie

Stoffeerders en lederwarenmakers

Patroonmakers, naaiers en zeilmakers

Houtzagers, papier- en kartonmakers

Timmerlieden

Productiepersoneel grafische industrie

Productiepersoneel chemische industrie

Vakkrachten metaalindustrie

Metaalbewerkers

Lassers, constructeurs en edelsmeden

Machinebank-, plaatwerkers en smeden

instrumentmakers en onderhoudsmonteurs

Automonteurs en -herstellers

Werktuigbouwkundigen

Hogere werktuigkundigen

Monteurs en controleurs elektrotechnische producten

Monteurs energievoorziening

Monteurs en controleurs elektrotechnische installaties

Elektrotechnische opzichters en uitvoerders

Elektrotechnische constructeurs en ingenieurs

Productiepersoneel aardewerk- en glasindustrie

Metselaars en stukadoors

$\begin{array}{ll}1,26 & \text { hoog } \\ 0,70 & \text { gemiddeld } \\ 1,22 & \text { hoog } \\ 0,88 & \text { gemiddeld } \\ 0,84 & \text { gemiddeld } \\ 1,32 & \text { hoog } \\ 0,75 & \text { gemiddeld } \\ 0,65 & \text { gemiddeld } \\ 0,62 & \text { gemiddeld } \\ 0,96 & \text { gemiddeld } \\ 0,61 & \text { gemiddeld } \\ 0,92 & \text { gemiddeld } \\ 0,93 & \text { gemiddeld } \\ 1,63 & \text { hoog } \\ 2,54 & \text { erg hoog } \\ 1,00 & \text { gemiddeld } \\ 0,46 & \text { laag } \\ 1,39 & \text { hoog } \\ 1,48 & \text { hoog } \\ 0,84 & \text { gemiddeld } \\ 0,84 & \text { gemiddeld } \\ 0,46 & \text { laag } \\ 0,90 & \text { gemiddeld } \\ 1,70 & \text { hoog } \\ 0,84 & \text { gemiddeld } \\ 1,74 & \text { hoog } \\ 1,92 & \text { erg hoog } \\ 2,36 & \text { erg hoog } \\ 2,79 & \text { erg hoog } \\ 0,91 & \text { gemiddeld } \\ 1,70 & \text { hoog } \\ & \end{array}$


Tabel 2.12 (vervolg)

Conjunctuurgevoeligheid per beroepsklasse

\begin{tabular}{lcl}
\hline Beroepsklasse & conjunctuurgevoeligheid & typering \\
\hline & & \\
Betonwerkers en glaszetters & 1,68 & hoog \\
Schilders & 1,73 & hoog \\
Loodgieters en installateurs & 4,54 & erg hoog \\
Wegenbouwvakkrachten en buizenleggers & 3,20 & erg hoog \\
Bouwkundige projectleiders & 1,25 & hoog \\
Architecten en bouwkundige ingenieurs & 1,39 & hoog
\end{tabular}

\section{TRANSPORTBEROEPEN}

\section{Expeditie-medewerkers}

Vissers en jachtopzieners

Scheepsdek- en machinekamerpersonee!

Schippers, officieren en loodsen

Chauffeurs en spoorwegpersoneel

Vliegers, verkeersleiders en expediteurs

\section{MEDISCHE EN PARAMEDISCHE BEROEPEN}

$\begin{array}{lll}\text { Verpleegkundigen } & 0,46 & \text { laag } \\ \text { Leerling-verpleegkundigen, zieken- en kraamverzorgenden } & 0,14 & \text { erg laag } \\ \text { Dokters-, tandarts- en dierenartsassistenten } & 0,14 & \text { erg laag } \\ \text { Opticiens en apothekersassistenten } & 0,59 & \text { gemiddeld } \\ \text { Paramedische en verwante functies } & 0,41 & \text { laag } \\ \text { Fysio-, arbeids- e.a. bewegingstherapeuten } & 0,14 & \text { erg laag } \\ \text { Analisten en laboranten } & 0,14 & \text { erg laag } \\ \text { Artsen, medische specialisten en apothekers } & 0,33 & \text { laag } \\ \text { Dierenartsen en diergeneeskundigen } & 0,64 & \text { gemiddeld } \\ \text { Tandheelkundigen } & 0,41 & \text { laag }\end{array}$

\section{ECONOMISCH-ADMINISTRATIEVE BEROEPEN}

Hogere leidinggevenden financiën, verkoop e.d.

Postbestellers en -sorteerders

gemiddeld

Operators en datatypisten

Leidinggevend administratief personeel

gemiddeld

Secretaresses en typisten

Bibliotheek- en archiefmedewerkers gemiddeld

Administrateurs en bankemployés

Commercieel-administratieve employés gemiddeld

Receptionisten, telefonisten en enquêteurs

Programmeurs en systeemanalisten gemiddeld

Economen en accountants

$\begin{array}{ll}0,85 & \text { gemiddeld } \\ 0,60 & \text { gemiddeld }\end{array}$

Verkooppersonee! gemiddeld

Winkeliers en handelaars

Filiaalhouders, inkopers en vertegenwoordigers

Beleidsmedewerkers en hoofdambtenaren

Advocaten, rechters en notarissen

\section{SOCIAAL-CULTURELE BEROEPEN}

$\begin{array}{ll}0,39 & \text { laag } \\ 0,28 & \text { laag }\end{array}$


Tabel 2.12 (vervolg)

Conjunctuurgevoeligheid per beroepsklasse

Beroepsklasse

conjunctuurgevoeligheid typering

Maatschappelijk werkers

Sociale wetenschappers

0,46

0,32

Huishoudkundige voorlichters

laag

VERZORGENDE EN DIENSTVERLENENDE BEROEPEN

Keuken- en serveerpersoneel

Leidinggevenden horeca

Portiers en schoonmaakpersoneel

Kinder-, gezins- en bejaardenverzorgenden

0,42

Kappers en schoonheidsspecialisten

laag

gemiddeld

laag

OPENBARE ORDE- EN VEILIGHEIDSBEROEPEN

Politie en beveiligingspersoneel

Bron: ROA 
Tabel 2.13

Verwachte uitbreidingsvraag per beroepsklasse, 1995-2000

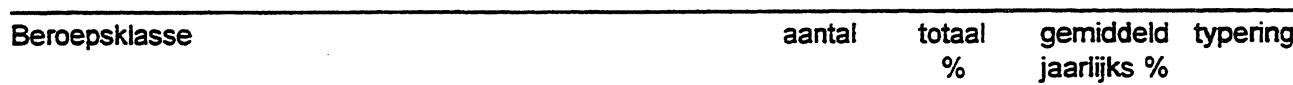

\section{PEDAGOGISCHE BEROEPEN}

Leerkrachten basis- en speciaal onderwijs $\quad-3.200$

Docenten voortgezet onderwijs $\quad 11.100$

Onderwijskundigen

Sportdocenten en -instructeurs

1.600

500

\section{CULTURELE BEROEPEN}

Taalkundigen, tolken en vertalers

Geestelijke verzorgers

Fotografen, ontwerpers en vormgevers

Regisseurs en kunstenaars

-3
7
3
4

$-0,7$

1,3

0,6

0,7

laag

gemiddeld

gemiddeld

gemiddeld

\section{AGRARISCHE BEROEPEN}

Uitvoerend agrarisch personeel

Bedrijfsleiders in de landbouw

$-14.400$

$-15.300$

1.100

$-13$

$-12$

$-2,8$

$-2,5$

Landbouw en milieu-ingenieurs

TECHNISCHE, AMBACHTS- EN INDUSTRIEBEROEPEN

Heftruckrijders

Machinisten bouw en industrie

Ondernemers, uitvoerders en bedrijfskundigen

Technische en medische vertegenwoordigers

Technisch tekenaars

Chemo-technici en laboranten

Natuurkundigen, technologen en statistici

Voedings- en genotmiddelenbereiders

Bakkers en chocolademakers

Productiepersoneel textielindustrie

Stoffeerders en lederwarenmakers

Patroonmakers, naaiers en zeilmakers

Houtzagers, papier- en kartonmakers

Timmerlieden

Productiepersoneel grafische industrie

Productiepersoneel chemische industrie

Vakkrachten metaalindustrie

Metaalbewerkers

Lassers, constructeurs en edelsmeden

Machinebank-, plaatwerkers en smeden

Instrumentmakers en onderhoudsmonteurs

10.000

$-2.500$

$-1.100$

$-1.100$

$-2.100$

$-1.900$

$-300$

$-6.700$

100

400

$-600$

$-1.500$

$-2.100$

$-2.000$

$-1.800$

Automonteurs en -herstellers

Werktuigbouwkundigen

Hogere werktuigkundigen

Monteurs en controleurs elektrotechnische producten

Monteurs energievoorziening

Monteurs en controleurs elektrotechnische installaties

Elektrotechnische opzichters en uitvoerders

Elektrotechnische constructeurs en ingenieurs

$-1.800$

$-1.200$

$-700$

500

100

400

$-400$

2.700
1,7

0,4

1,2

3,1

hoog

gemiddeld

gemiddeld

hoog

erg laag

erg hoog

\section{erg laag}

5
2
15
5
12
12
18
-6
-5
-12
-12
-11
-3
-5
0
1
-5
-5
-4
-3
-3
-4
-9
-7
2
4
0
-8
19

gemiddeld

gemiddeld

hoog

gemiddeld

hoog

hoog

erg hoog

laag

laag

erg laag

erg laag

erg laag

laag

laag

gemiddeld

gemiddeld

laag

laag

laag

laag

laag

laag

laag

laag

gemiddeld

gemiddeld

gemiddeld

$-1,6$ laag

3,5 erg hoog 
Tabel 2.13 (vervoig)

Verwachte uitbreidingsvraag per beroepsklasse, 1995-2000

Beroepsklasse $\quad$ aantal $\begin{gathered}\text { totaal } \\ \%\end{gathered} \underset{\text { jaarlijks \% }}{\text { gemiddeld typering }}$

Productiepersoneel aardewerk- en glasindustrie

Metselaars en stukadoors

Betonwerkers en glaszetters

Schilders

Loodgieters en installateurs

Wegenbouwvakkrachten en buizenleggers

Bouwkundige projectleiders

Architecten en bouwkundige ingenieurs

\section{TRANSPORTBEROEPEN}

Expeditie-medewerkers

Vissers en jachtopzieners

Scheepsdek- en machinekamerpersoneel

Schippers, officieren en loodsen

Chauffeurs en spoonwegpersoneel

Vliegers, verkeersleiders en expediteurs

\section{MEDISCHE EN PARAMEDISCHE BEROEPEN}

Verpleegkundigen

Leerling-verpleegkundigen, zieken- en kraamverzorgenden

Dokters-, tandarts- en dierenartsassistenten

Opticiens en apothekersassistenten

Paramedische en verwante functies

Fysio-, arbeids- e.a. bewegingstherapeuten

Analisten en laboranten

Artsen, medische specialisten en apothekers

Dierenartsen en diergeneeskundigen

Tandheelkundigen

\section{ECONOMISCH-ADMINISTRATIEVE BEROEPEN}

Hogere leidinggevenden financiën, verkoop e.d.

Postbestellers en -sorteerders

Operators en datatypisten

Leidinggevend administratief personeel

Secretaresses en typisten

Bibliotheek- en archiefmedewerkers

Administrateurs en bankemployés

Commercieel-administratieve employés

Receptionisten, telefonisten en enquêteurs

Programmeurs en systeemanalisten

Economen en accountants

Verkooppersoneel

Winkeliers en handelaars

Filiaalhouders, inkopers en vertegenwoordigers

Beleidsmedewerkers en hoofdambtenaren

Advocaten, rechters en notarissen
$-2.300$

$-2.800$

$-2.200$

$-2.500$

$-3.100$

$-4.000$

$-400$

1.600

2.100

$-100$

$-100$

200

2.300

600

-7
-6
-9
-8
-8
-7
-2

$-1,3$

laag

$-1,3$ laag

$-1,8$ laag

$-1,6$ laag

$-1,6$ laag

$-1,4 \quad$ laag

$-0,3$ gemiddeld

0,9 gemiddeld

$\begin{array}{rrl}-2 & -0,3 & \text { gemiddeld } \\ 5 & 0,9 & \text { gemiddeld }\end{array}$

$\begin{array}{rrl}2 & 0,3 & \text { gemiddeld } \\ -5 & -1,1 & \text { laag } \\ -2 & -0,3 & \text { gemiddeld } \\ 2 & 0,3 & \text { gemiddeld } \\ 1 & 0,3 & \text { gemiddeld } \\ 3 & 0,6 & \text { gemiddeld }\end{array}$

16.600

13.600

2.300

1.000

2.600

6.600

2.500

5.000

300

500

15
11
10
5
10
20
9
12
10
9

2,8

hoog

hoog

hoog

gemiddeld

hoog

erg hoog

hoog

hoog

hoog

hoog

$\begin{array}{rrrl}18.100 & 18 & 3,4 & \text { erg hoog } \\ -1.000 & -3 & -0,5 & \text { laag } \\ -1.500 & -13 & -2,8 & \text { erg laag } \\ 800 & 3 & 0,6 & \text { gemiddeld } \\ -2.900 & -2 & -0,4 & \text { gemiddeld } \\ -900 & -4 & -0,9 & \text { laag } \\ -6.700 & -2 & -0,4 & \text { gemiddeld } \\ -23.000 & -6 & -1,3 & \text { laag } \\ 1.400 & 2 & 0,3 & \text { gemiddeld } \\ 66.700 & 50 & 8,4 & \text { erg hoog } \\ 15.700 & 26 & 4,7 & \text { erg hoog } \\ 42.300 & 16 & 3,0 & \text { hoog } \\ 15.700 & 9 & 1,8 & \text { hoog } \\ 13.700 & 11 & 2,0 & \text { hoog } \\ -5.100 & -19 & -4,0 & \text { erg laag } \\ 400 & 1 & 0,3 & \text { gemiddeld }\end{array}$


Tabel 2.13 (vervolg)

Verwachte uitbreidingsvraag per beroepsklasse, 1995-2000

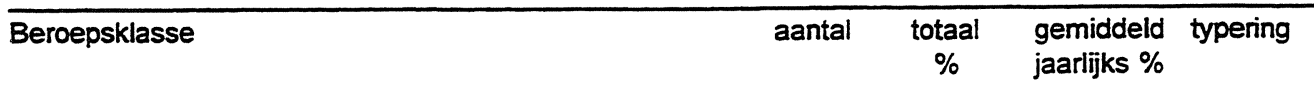

\section{SOCIAAL-CULTURELE BEROEPEN}

$\begin{array}{lrrrl}\text { Joumalisten en presentatoren } & 7.200 & 21 & 4,0 & \text { erg hoog } \\ \text { Bibliothecarissen en archivarissen } & 2.700 & 16 & 3,0 & \text { hoog } \\ \text { Arbeidsconsulenten en personeelsdeskundigen } & 2.700 & 8 & 1,5 & \text { gemiddeld } \\ \text { Maatschappelijk werkers } & 4.200 & 6 & 1,2 & \text { gemiddeld } \\ \text { Sociale wetenschappers } & 600 & 3 & 0,6 & \text { gemiddeld }\end{array}$

VERZORGENDE EN DIENSTVERLENENDE BEROEPEN

$\begin{array}{lrrrl}\text { Keuken- en serveerpersoneel } & 1.100 & 1 & 0,2 & \text { gemiddeld } \\ \text { Leidinggevenden horeca } & 1.200 & 2 & 0,4 & \begin{array}{l}\text { gemiddeld } \\ \text { Portiers en schoonmaakpersoneel }\end{array} \\ \text { Kinder-, gezins- en bejaardenverzorgenden } & -17.000 & -11 & -2,3 & \text { laag } \\ \text { Kappers en schoonheidsspecialisten } & 7.400 & 6 & 1,2 & \begin{array}{l}\text { gemiddeld } \\ \text { laag }\end{array} \\ \text { OPENBARE ORDE- EN VEILIGHEIDSBEROEPEN } & -3.800 & -11 & -2,3 & \\ & & & & \\ \begin{array}{l}\text { Politie en beveiligingspersoneel } \\ \text { Beroepsmilitairen }\end{array} & 3.600 & 6 & 1,1 & \text { gemiddeld } \\ \end{array}$

Bron: ROA 
Tabel 2.14

Verwachte vervangingsvraag per beroepsklasse, 1995-2000

Beroepsklasse

aantal totaal gemiddeld typering

$\%$ jaarlijks \%

PEDAGOGISCHE BEROEPEN

Leerkrachten basis- en speciaal ondenwijs

24.100

37.600

8.900

1.900

25
23
17
15

4,5

Onderwijskundigen

Sportdocenten en -instructeurs

\section{CULTURELE BEROEPEN}

Taalkundigen, tolken en vertalers

1.400

2.300

6.800

5.300

22
29
18
15

4,0

Geestelijke verzorgers

Fotografen, ontwerpers en vormgevers

Regisseurs en kunstenaars

TECHNISCHE, AMBACHTS- EN INDUSTRIEBEROEPEN

\section{Heftruckrijders}

Machinisten bouw en industrie

Ondernemers, uitvoerders en bedrijfskundigen

Technische en medische vertegenwoordigers

Technisch tekenaars

Chemo-technici en laboranten

Natuurkundigen, technologen en statistici

Voedings- en genotmiddelenbereiders

Bakkers en chocolademakers

Productiepersoneel textielindustrie

Stoffeerders en lederwarenmakers

Patroonmakers, naaiers en zeilmakers

Houtzagers, papier- en kartonmakers

Timmeriteden

Productiepersoneel grafische industrie

Productiepersoneel chemische industrie

Vakkrachten metaalindustrie

Metaalbewerkers

Lassers, constructeurs en edelsmeden

Machinebank-, plaatwerkers en smeden

instrumentmakers en onderhoudsmonteurs

Automonteurs en -herstellers

Werktuigbouwkundigen

Hogere werktuigkundigen

Monteurs en controleurs elektrotechnische producten

Monteurs energievoorziening

Monteurs en controleurs elektrotechnische installaties

Elektrotechnische opzichters en uitvoerders gemiddeld

hoog

gemiddeld

laag

laag

erg hoog

gemiddeld

laag

gemiddeld

gemiddeld

gemiddeld

erg laag

gemiddeld

hoog

gemiddeld

hoog

laag

gemiddeld

laag

gemiddeld

gemiddeld

gemiddeld

gemiddeld

laag

laag

laag

laag

hoog

erg hoog

gemiddeld

hoog

gemiddeld

laag

erg laag

gemiddeld

erg hoog 
Tabel 2.14 (vervolg)

Verwachte vervangingsvraag per beroepsklasse, $1995-2000$

\begin{tabular}{|c|c|c|c|c|}
\hline Beroepsklasse & aantal & $\begin{array}{c}\text { totaal } \\
\%\end{array}$ & $\begin{array}{l}\text { gemiddeld } \\
\text { jaarlijks \% }\end{array}$ & typering \\
\hline $\begin{array}{l}\text { Elektrotechnische constructeurs en ingenieurs } \\
\text { Productiepersoneel aardewerk- en glasindustrie } \\
\text { Metselaars en stukadoors } \\
\text { Betonwerkers en glaszetters } \\
\text { Schilders } \\
\text { Loodgieters en installateurs } \\
\text { Wegenbouwvakkrachten en buizenleggers } \\
\text { Bouwkundige projectleiders } \\
\text { Architecten en bouwkundige ingenieurs }\end{array}$ & $\begin{array}{r}3.000 \\
6.500 \\
12.000 \\
4.400 \\
9.500 \\
7.100 \\
7.100 \\
5.500 \\
4.300\end{array}$ & $\begin{array}{l}20 \\
18 \\
26 \\
17 \\
29 \\
17 \\
12 \\
20 \\
13\end{array}$ & $\begin{array}{l}3,8 \\
3,4 \\
4,8 \\
3,2 \\
5,2 \\
3,3 \\
2,3 \\
3,8 \\
2,5\end{array}$ & $\begin{array}{l}\text { gemiddeld } \\
\text { gemiddeld } \\
\text { hoog } \\
\text { laag } \\
\text { erg hoog } \\
\text { laag } \\
\text { erg laag } \\
\text { gemiddeld } \\
\text { laag }\end{array}$ \\
\hline \multicolumn{5}{|l|}{ TRANSPORTBEROEPEN } \\
\hline $\begin{array}{l}\text { Expeditie-medewerkers } \\
\text { Vissers en jachtopzieners } \\
\text { Scheepsdek- en machinekamerpersoneel } \\
\text { Schippers, officieren en loodsen } \\
\text { Chauffeurs en spoorwegpersoneel } \\
\text { Vliegers, verkeersleiders en expediteurs }\end{array}$ & $\begin{array}{r}18.500 \\
300 \\
600 \\
1.500 \\
45.900 \\
3.700\end{array}$ & $\begin{array}{l}16 \\
10 \\
11 \\
15 \\
25 \\
19\end{array}$ & $\begin{array}{l}2,9 \\
2,0 \\
2,1 \\
2,7 \\
4,5 \\
3,6\end{array}$ & $\begin{array}{l}\text { laag. } \\
\text { erg laag } \\
\text { erg laag } \\
\text { laag } \\
\text { hoog } \\
\text { gemiddeld }\end{array}$ \\
\hline
\end{tabular}

\section{MEDISCHE EN PARAMEDISCHE BEROEPEN}

$\begin{array}{lrrrl}\text { Verpleegkundigen } & 29.600 & 27 & 4,8 & \text { hoog } \\ \text { Leerling-verpleegkundigen, zieken- en kraamverzorgenden } & 38.900 & 31 & 5,6 & \text { erg hoog } \\ \text { Dokters-, tandarts- en dierenartsassistenten } & 6.000 & 26 & 4,7 & \text { hoog } \\ \text { Opticiens en apothekersassistenten } & 3.500 & 18 & 3,4 & \text { gemiddeld } \\ \text { Paramedische en verwante functies } & 4.200 & 17 & 3,2 & \text { laag } \\ \text { Fysio-, arbeids- e.a. bewegingstherapeuten } & 7.200 & 22 & 4,1 & \text { gemiddeld } \\ \text { Analisten en laboranten } & 7.200 & 25 & 4,6 & \text { hoog } \\ \text { Artsen, medische specialisten en apothekers } & 10.300 & 25 & 4,6 & \text { hoog } \\ \text { Dierenartsen en diergeneeskundigen } & 600 & 18 & 3,3 & \text { gemiddeld } \\ \text { Tandheelkundigen } & 1.200 & 23 & 4,3 & \text { gemiddeld } \\ & & & & \\ \text { ECONOMISCH-ADMINISTRATIEVE BEROEPEN } & & & & \\ & & & & \\ \text { Hogere leidinggevenden financiën, verkoop e.d. } & 26.300 & 26 & 4,8 & \text { hoog } \\ \text { Postbestellers en -sorteerders } & 9.000 & 24 & 4,4 & \text { hoog } \\ \text { Operators en datatypisten } & 1.200 & 11 & 2,0 & \text { erg laag } \\ \text { Leidinggevend administratief personeel } & 5.300 & 22 & 4,0 & \text { gemiddeld } \\ \text { Secretaresses en typisten } & 36.600 & 27 & 4,9 & \text { hoog } \\ \text { Bibliotheek- en archiefmedewerkers } & 4.900 & 24 & 4,3 & \text { hoog } \\ \text { Administrateurs en bankemployés } & 63.200 & 18 & 3,3 & \text { gemiddeld } \\ \text { Commercieet-administratieve employes } & 49.900 & 14 & 2,6 & \text { laag } \\ \text { Receptionisten, telefonisten en enquêteurs } & 17.200 & 21 & 3,9 & \text { gemiddeld } \\ \text { Programmeurs en systeemanalisten } & 30.800 & 23 & 4,2 & \text { gemiddeld } \\ \text { Economen en accountants } & 11.800 & 20 & 3,6 & \text { gemiddeld } \\ \text { Verkooppersoneel } & 48.000 & 18 & 3,4 & \text { gemiddeld } \\ \text { Winkeliers en handelaars } & 32.300 & 19 & 3,5 & \text { gemiddeld } \\ \text { Filiaalhouders, inkopers en vertegenwoordigers } & 31.100 & 24 & 4,4 & \text { hoog } \\ \text { Beleidsmedewerkers en hoofdambtenaren } & 9.000 & 33 & 5,8 & \text { erg hoog } \\ \text { Advocaten, rechters en notarissen } & 8.100 & 25 & 4,6 & \text { hoog } \\ & & & & \end{array}$


Tabel 2.14 (vervolg)

Verwachte vervangingsvraag per beroepsklasse, 1995-2000

Beroepsklasse

aantal

totaal gemiddeld typering

$\%$ jaarlijks \%

SOCIAAL-CULTURELE BEROEPEN

Journalisten en presentatoren

8.200

3.100

4.900

Bibliothecarissen en archivarissen

17.900

Arbeidsconsulenten en personeelsdeskundigen

4.600

Sociale wetenschappers

2.700

24
18
14
26
21
20

4,5 hoog

3,4 gemiddeld

2,7 laag

4,7 hoog

Huishoudkundige voorlichters

gemiddeld

VERZORGENDE EN DIENSTVERLENENDE BEROEPEN

\begin{tabular}{|c|c|c|c|c|}
\hline Keuken- en serveerpersoneel & 28.200 & 21 & 3,8 & gemiddeld \\
\hline Leidinggevenden horeca & 18.200 & 27 & 4,9 & hoog \\
\hline Portiers en schoonmaakpersoneel & 31.500 & 21 & 3,8 & gemiddeld \\
\hline Kinder-, gezins- en bejaardenverzorgenden & 26.100 & 21 & 3,9 & gemiddeld \\
\hline Kappers en schoonheidsspecialisten & 4.900 & 14 & 2,7 & laag \\
\hline \multicolumn{5}{|c|}{ OPENBARE ORDE- EN VEILIGHEIDSBEROEPEN } \\
\hline $\begin{array}{l}\text { Politie en beveiligingspersoneel } \\
\text { Beroepsmilitairen }\end{array}$ & $\begin{array}{r}14.500 \\
3.800\end{array}$ & $\begin{array}{l}23 \\
12\end{array}$ & $\begin{array}{l}4,2 \\
2,3\end{array}$ & $\begin{array}{l}\text { gemiddeld } \\
\text { erg laag }\end{array}$ \\
\hline
\end{tabular}

Bron: ROA 







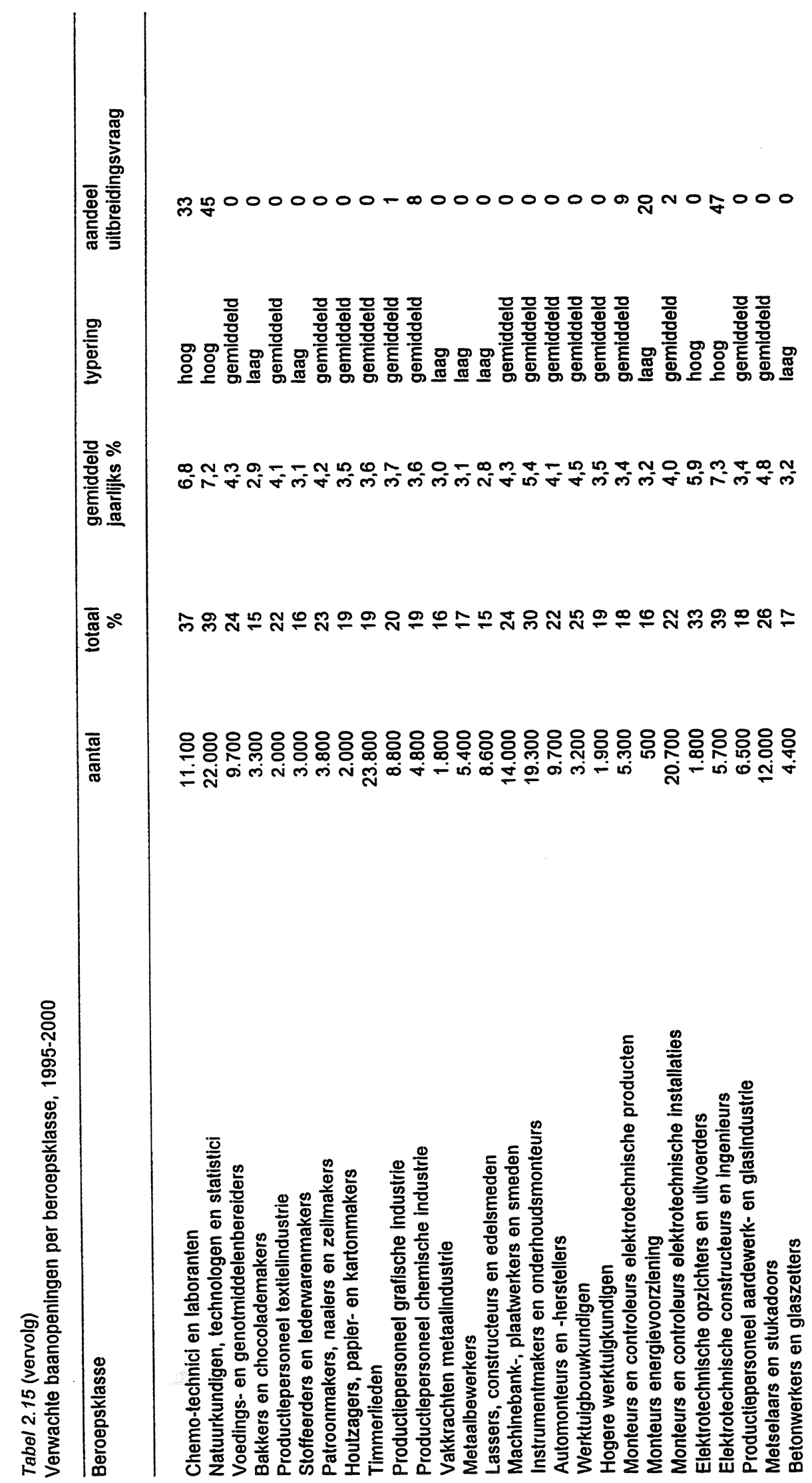




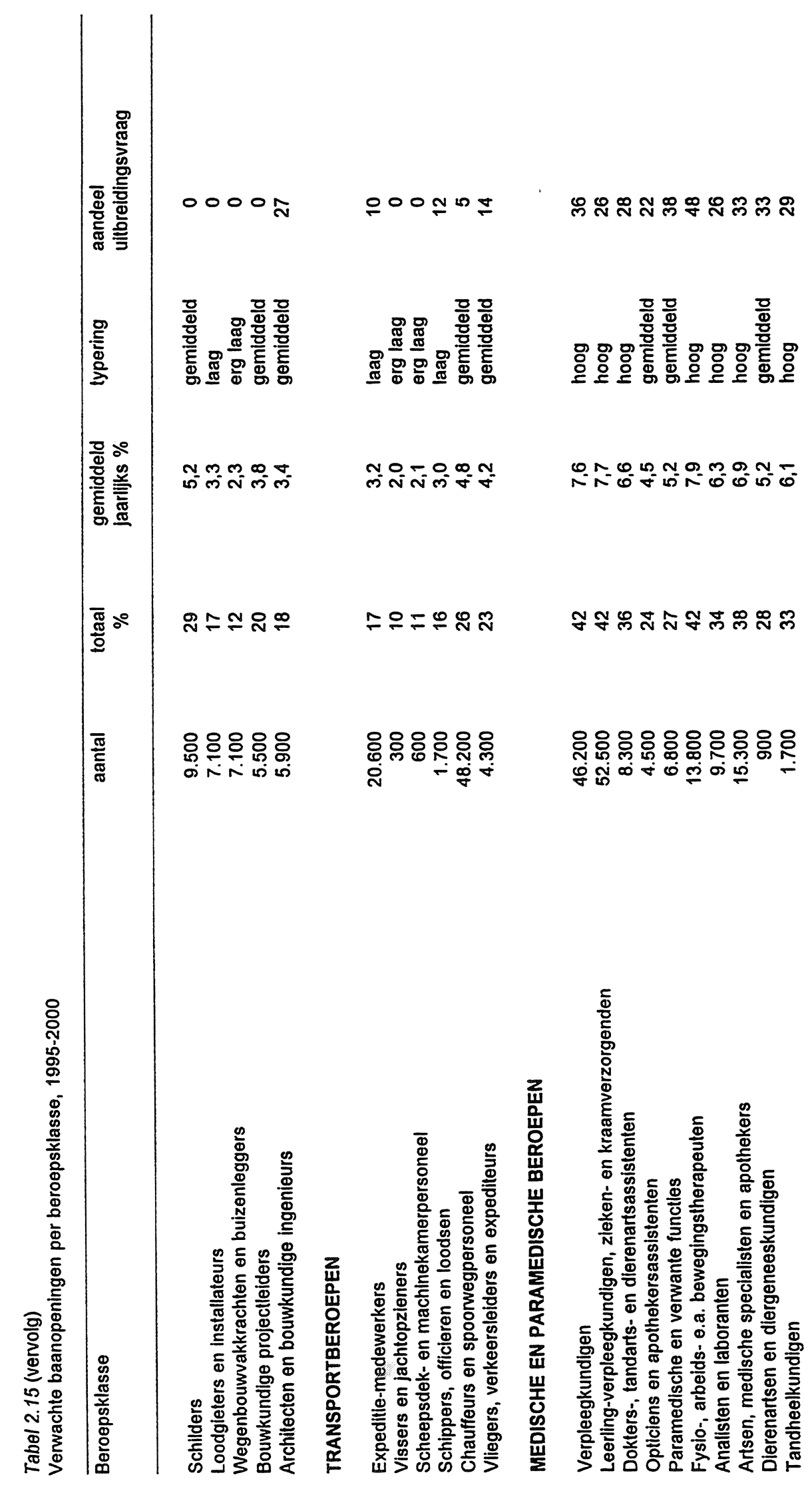




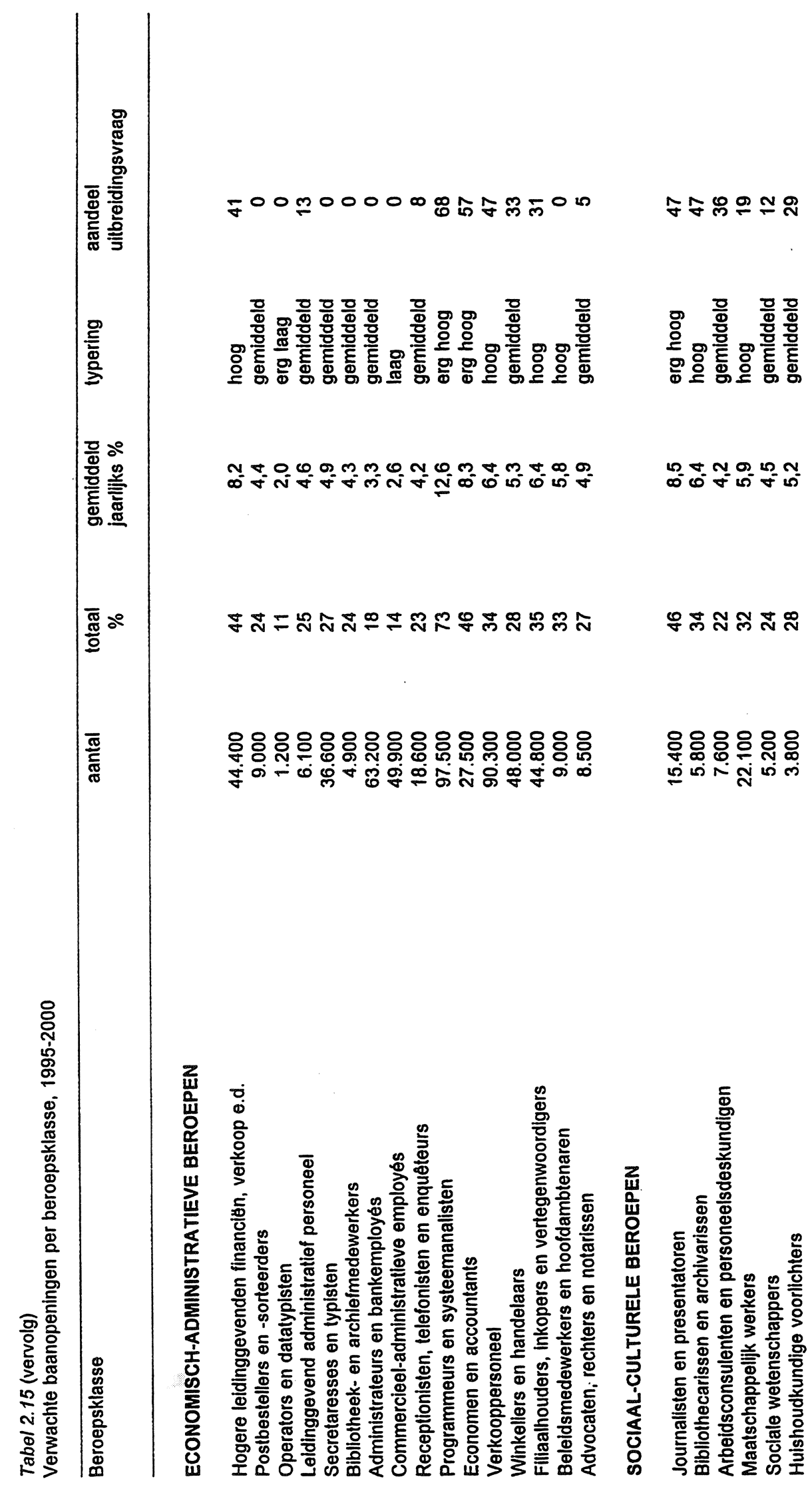




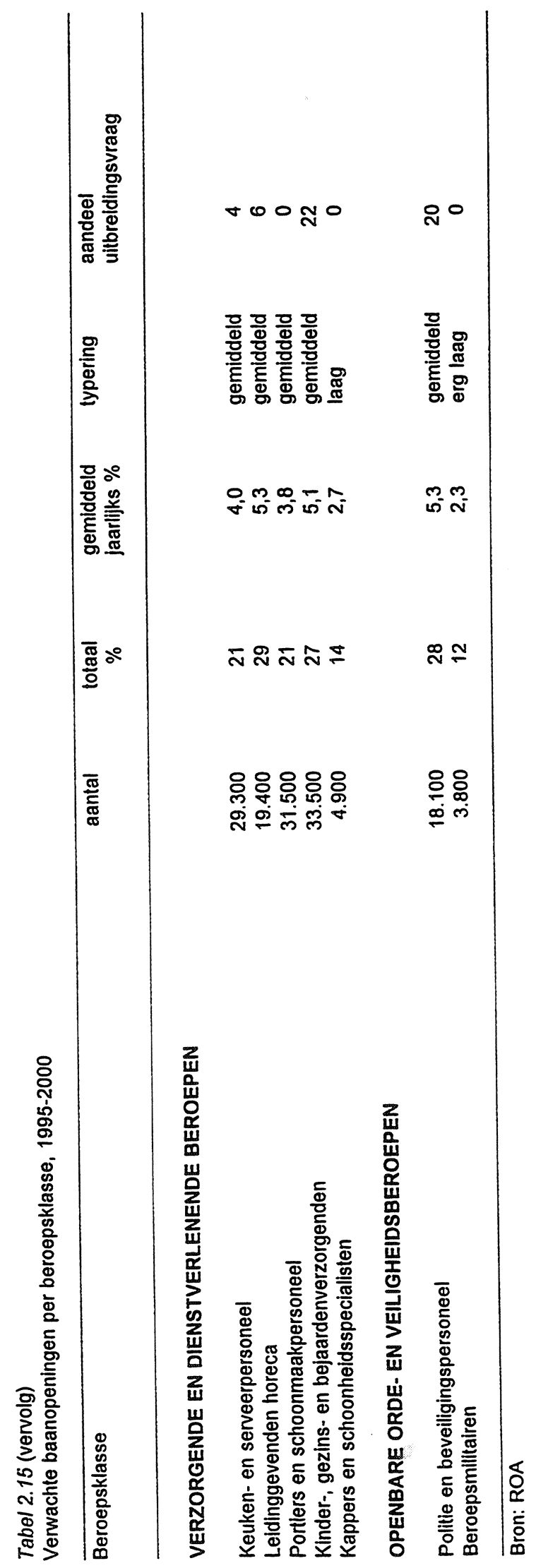



3 INFORMATIE OVER OPLEIDINGEN 

Figuur 3.1

Verwachte baanopeningen verdeeld naar uitbreidings- en vervangingsvraag per opleidingscategorie, 19952000 (gemiddeld jaarlijks percentage)

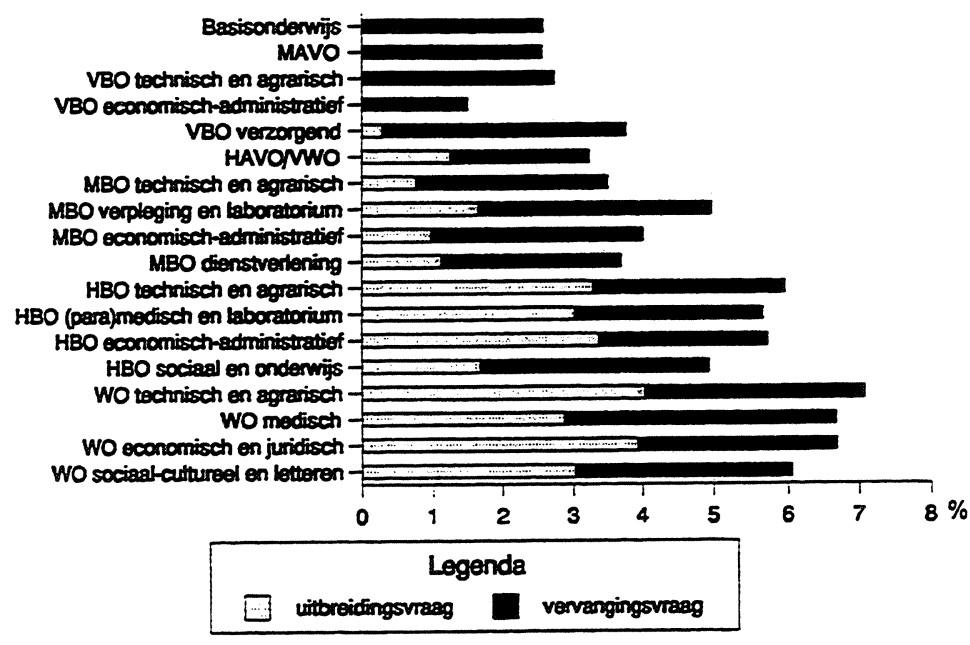

Bron: ROA

Figuur 3.2

Verwachte instroom van schoolverlaters per opleidingscategorie, 1995-2000 (gemiddeld jaarlijks percentage)

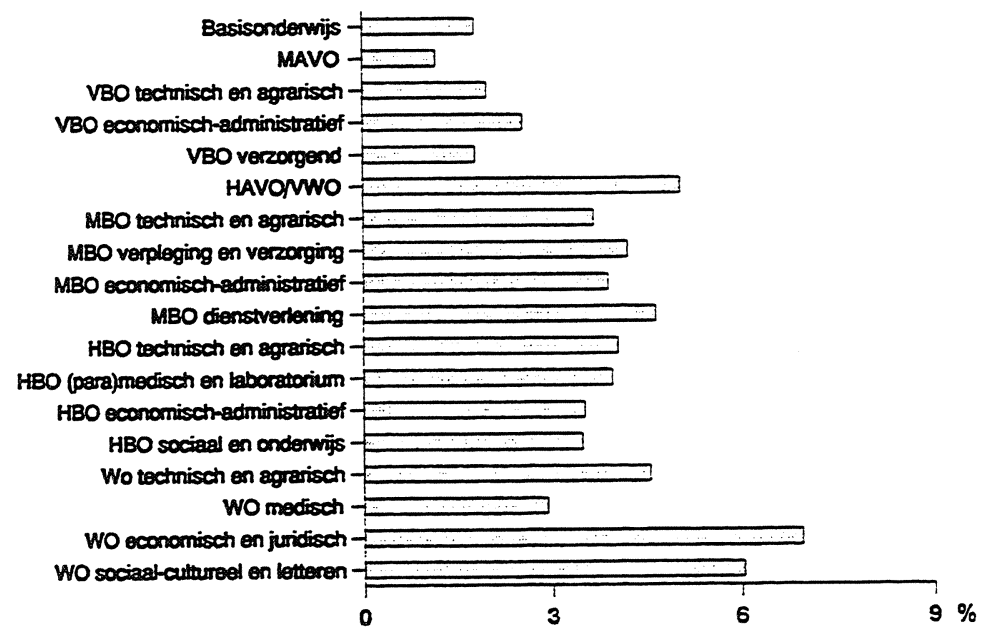

Bron: ROA 
Figuur 3.3

Arbeidsmarktperspectieven voor schoolverlaters per opleidingscategorie in 2000



Bron: ROA 
Tabel 3.1

Participatie schoolverlaters in vervolgopleidingen per opleidingsrichting, 1995

\begin{tabular}{lccc}
\hline Opleidingstype en -richting & $\begin{array}{c}\text { studie } \\
\%\end{array}$ & typering & $\begin{array}{c}\text { LLW/Inservice } \\
\%\end{array}$ \\
\hline
\end{tabular}

MAVO, VBO

\begin{tabular}{|c|c|c|c|c|}
\hline MAVO en onderbouw HAVOMWO & 92 & erg hoog & 3 & gemiddeld \\
\hline VBO land- en tuinbouw & 77 & erg hoog & 13 & gemiddeld \\
\hline \multicolumn{5}{|l|}{ VBO technisch } \\
\hline VBO bouwtechniek & 24 & gemiddeld & 60 & erg hoog \\
\hline VBO mechanische techniek & 40 & gemiddeld & 42 & erg hoog \\
\hline VBO motorvoertuigentechniek & 33 & gemiddeld & 56 & erg hoog \\
\hline VBO elektrotechniek. & 63 & hoog & 24 & hoog \\
\hline VBO grafische techniek & 63 & hoog & 10 & gemiddeld \\
\hline VBO consumptieve techniek & 40 & gemiddeld & 40 & hoog \\
\hline VBO textiel- en ledertechniek & 69 & erg hoog & 9 & gemiddeld \\
\hline \multicolumn{5}{|l|}{ VBO economisch-administratief } \\
\hline VBO administratie & 79 & erg hoog & 11 & gemiddeld \\
\hline VBO verkoop en handel & 67 & erg hoog & 13 & gemiddeld \\
\hline \multicolumn{5}{|l|}{ VBO verzorgend } \\
\hline VBO verzorging & 74 & erg hoog & 12 & gemiddeld \\
\hline VBO uiterlijke verzorging & 53 & hoog & 24 & hoog \\
\hline \multicolumn{5}{|l|}{ HAVONWO, MBO } \\
\hline \multicolumn{5}{|l|}{ HAVONWO bovenbouw } \\
\hline HAVO & 91 & erg hoog & 2 & laag \\
\hline WWO & 94 & erg hoog & 0 & erg laag \\
\hline \multicolumn{5}{|c|}{ MBO landbouw en natuurlijke omgeving } \\
\hline KMBO agrarisch & 18 & laag. & 9 & gemiddeld \\
\hline MBO plantenteelt & 30 & gemiddeld & 2 & laag. \\
\hline MBO veehouderij & 30 & gemiddeld & 5 & gemiddeld \\
\hline MBO levensmiddelentechnologie & 36 & gemiddeld & 2 & laag \\
\hline MBO bloemschikken & 13 & laag. & 6 & gemiddeld \\
\hline MBO dierenverzorging & 26 & gemiddeld & 0 & erg laag \\
\hline MBO groene ruimte & 38 & gemiddeld & 6 & gemiddeld \\
\hline \multicolumn{5}{|l|}{ MBO technisch laboratorium } \\
\hline MBO chemisch laboratorium & 38 & gemiddeld & 1 & erg laag \\
\hline \multicolumn{5}{|l|}{ MBO technisch } \\
\hline KMBO motorvoertuigentechniek & 11 & erg laag & 54 & erg hoog \\
\hline KMBO elektrotechniek & 14 & laag & 26 & hoog \\
\hline KMBO consumptieve techniek & 13 & laag & 37 & hoog \\
\hline MBO bouwkunde & 45 & hoog & 2 & laag. \\
\hline MBO weg-en waterbouwkunde & 16 & laag. & 8 & gemiddeld \\
\hline MBO mechanische techniek & 39 & gemiddeld & 7 & gemiddeld \\
\hline MBO werktuigbouwkunde & 38 & gemiddeld & 4 & gemiddeld \\
\hline MBO motorvoertuigentechniek & 40 & gemiddeld & 11 & gemiddeld \\
\hline MBO elektrotechniek & 41 & gemiddeld & 2 & laag \\
\hline MBO textiel- en ledertechniek & 38 & gemiddeld & 0 & erg laag \\
\hline
\end{tabular}


Tabel 3.1 (vervolg)

Participatie schoolverlaters in vervolgopleidingen per opleidingsrichting, 1995

\begin{tabular}{|c|c|c|c|c|}
\hline Opleidingstype en -richting & $\begin{array}{l}\text { studie } \\
\%\end{array}$ & typering & $\begin{array}{c}\text { LLW/Inservice } \\
\%\end{array}$ & typering \\
\hline MBO haven en vervoer & 44 & hoog & 1 & erg laag \\
\hline \multicolumn{5}{|c|}{ MBO verpleging en medische assistentie } \\
\hline MBO verpl. en ziekenverzorging & 46 & hoog & 20 & gemiddeld \\
\hline MBO assistent gezondheidszorg & 14 & laag & 4 & gemiddeld \\
\hline \multicolumn{5}{|l|}{ MBO economisch-administratief } \\
\hline KMBO detailhandel & 39 & gemiddeld & 5 & gemiddeld \\
\hline KMBO administratie & 41 & gemiddeld & 6 & gemiddeld \\
\hline MBO handel & 32 & gemiddeld & 2 & laag \\
\hline MBO administratie & 57 & hoog & 1 & erg laag \\
\hline MBO toerisme & 30 & gemiddeld & 0 & erg laag \\
\hline MBO commercieel & 48 & hoog & 1 & erg laag \\
\hline MBO secretarieel & 18 & laag & 1 & erg laag \\
\hline MBO bestuurlijk & 39 & gemiddeld & 0 & erg laag \\
\hline MBO sociale arbeid & 51 & hoog & 0 & erg laag \\
\hline \multicolumn{5}{|l|}{ MBO verzorgend } \\
\hline KMBO verzorging & 34 & gemiddeld & 20 & gemiddeld \\
\hline MBO agogisch werk & 35 & gemiddeld & 10 & gemiddeld \\
\hline MBO verzorging & 11 & erg laag & 24 & hoog \\
\hline MBO mode en kleding & 36 & gemiddeld & 1 & erg laag \\
\hline MBO activiteitenbegeleiding & 28 & gemiddeld & 4 & gemiddeld \\
\hline \multicolumn{5}{|l|}{ MBO horeca en uiterlijke verzorging } \\
\hline MBO horeca & 26 & gemiddeld & 1 & erg laag \\
\hline MBO facilitaire dienstverlening & 29 & gemiddeld & 12 & gemiddeld \\
\hline MBO uiterlijke verzorging & 16 & laag & 3 & gemiddeld \\
\hline \multicolumn{5}{|l|}{ HBO } \\
\hline \multicolumn{5}{|l|}{ HBO onderwijs } \\
\hline HBO basisonderwijzer & 10 & erg laag & n.v.t. & n.v.t. \\
\hline HBO leraar agrarisch & 5 & erg laag & & \\
\hline HBO leraar kunst/expressie & 16 & laag & & \\
\hline HBO leraar voortgezet onderwijs & 17 & laag & & \\
\hline HBO tolk en vertaler & 24 & gemiddeld & & \\
\hline HBO agrarisch & 17 & laag & & \\
\hline HBO technisch laboratorium & 18 & laag & & \\
\hline \multicolumn{5}{|l|}{ HBO technisch } \\
\hline HBO (weg-en water)bouwkunde & 16 & laag & & \\
\hline HBO werktuigbouwkunde & 11 & erg laag & & \\
\hline HBO elektrotechiek & 10 & erg laag & & \\
\hline HBO haven en vervoer & 3 & erg laag & & \\
\hline
\end{tabular}


Tabel 3.1 (vervolg)

Participatie schoolverlaters in vervolgopleidingen per opleidingsrichting, 1995

\begin{tabular}{|c|c|c|c|c|}
\hline Opleidingstype en -richting & $\begin{array}{l}\text { studie } \\
\%\end{array}$ & typering & $\begin{array}{c}\text { LLW/nservice } \\
\%\end{array}$ & typering \\
\hline HBO medisch analist & 9 & erg laag & n.v.t. & n.v.t. \\
\hline $\begin{array}{l}\text { HBO verpleging en paramedisch } \\
\text { HBO verpleegkunde } \\
\text { HBO (fysio-)therapie }\end{array}$ & $\begin{array}{l}8 \\
8\end{array}$ & $\begin{array}{l}\text { erg laag } \\
\text { erg laag }\end{array}$ & & \\
\hline $\begin{array}{l}\text { HBO economisch-administratief } \\
\text { HBO bedrijfseconomie } \\
\text { HBO accountancy } \\
\text { HBO bedrijfsinformatica } \\
\text { HBO toerisme } \\
\text { HBO commerciële economie }\end{array}$ & $\begin{array}{r}17 \\
3 \\
13 \\
11 \\
17\end{array}$ & $\begin{array}{l}\text { laag } \\
\text { erg laag } \\
\text { laag } \\
\text { erg laag } \\
\text { laag }\end{array}$ & & \\
\hline HBO technische bedrijfskunde & 10 & erg laag & & \\
\hline HBO bestuurlijk/juridisch & 36 & gemiddeld & & \\
\hline $\begin{array}{l}\text { HBO sociaal-cultureel } \\
\text { HBO welzijnswerk/sociaal } \\
\text { HBO personeelswerk } \\
\text { HBO joumalistiek }\end{array}$ & $\begin{array}{l}10 \\
11 \\
18\end{array}$ & $\begin{array}{l}\text { erg laag } \\
\text { erg laag } \\
\text { laag }\end{array}$ & & \\
\hline HBO kunst & 8 & erg laag & & \\
\hline
\end{tabular}

Bron: RUBS/HBO-Monitor/ROA 
Tabel 3.2

Aantal werkenden per opleidingstype, gemiddelde 1994-1995

Opleidingstype aantal werkenden trend

1993-'95

\section{BASISONDERWJS}

Basisonderwijs

495.500

constant

MAVO, VBO

MAVO, onderbouw HAVOMWO

410.000

VBO landbouw en natuurijke omgeving

76.000

VBO bouwtechniek

132.000

VBO installatietechniek

10.000

VBO mechanische techniek

129.000

VBO motorvoertuigentechniek

45.500

VBO elektrotechniek

58.000

VBO grafische techniek

58.000
6.500

VBO consumptieve techniek

20.000

VBO textiel- en ledertechniek

22.000

VBO haven en vervoer

37.500
61.500

VBO administratie

VBO verkoop en handel

30.000

VBO verzorging

198.500

VBO bewaking

11.000

dalend
dalend
-
dalend
-
dalend
sterk dalend
dalend
-
stijgend
constant
dalend
-
sterk stijgend

HAVONWO, MBORLW

HAVOMWO bovenbouw

305.500

MBORLW landbouw en natuurlijke omgeving

133.500

MBO technisch laboratorium

14.000

MBO/LLW bouwkunde

162.500

MBOLLW weg- en waterbouwkunde

23.500

MBO/LLW metaalkunde

61.000

14.000

89.000

$M B O / L W W$ werktuigbouwkunde

64.000

145.500

MBORLW elektrotechniek

37.000

39.500

MBO/LLW consumptieve techniek

18.500

34.000

MBO/LLW textiel- en ledertechniek

48.500

196.500

$M B O / L L W$ verpleging en medische assistentie

196.500
27.000

MBO/LLW medisch laboratorium

319.500

MBO/LLW hande

93.500

14.500

MBO toerisme en recreatie

14.500
34.500

95.000

MBO/LLW secretarieel

95.000
45.000

56.000
214.500

MBO sociaal-cultureel

$M B O / L L W$ verzorging

MBO/LLW horeca en uiterlijke verzorging

61.000

MBO politie en defensie

87.000

stijgend

stijgend

sterk stijgend

dalend

constant

constant

constant

dalend

constant

dalend

constant

-

stijgend

sterk stijgend 
Tabel 3.2 (vervolg)

Aantal werkenden per opleidingstype, gemiddelde 1994-1995

Opleidingstype aantal werkenden trend

1993-'95

HBO

HBO onderwijs

HBO tolk en vertaler

HBO landbouw en milieukunde

$\mathrm{HBO}$ technisch laboratorium

HBO (weg- en water)bouwkunde

$\mathrm{HBO}$ werktuigbouwkunde

HBO elektrotechniek en technische informatica

$H B O$ haven en vervoer

HBO medisch laboratorium

$H B O$ verpleging en paramedisch

$\mathrm{HBO}$ bedrijfseconomie

HBO accountancy

HBO bedrijfsinformatica

HBO toerisme en recreatie

HBO commerciële economie

$\mathrm{HBO}$ technische bedriifskunde

$\mathrm{HBO}$ bestuurijk-juridisch

HBO sociaal-cultureel

HBO kunst

HBO politie en defensie

wo

Wo letteren

WO theologisch

WO landbouw en milieukunde

WO wiskunde en natuurwetenschappen

WO (weg- en water)bouwkunde

WO werktuigbouwkunde

WO elektrotechniek en technische informatica

WO dier-, genees- en tandheelkunde

WO farmacie

WO econom(etr)ie en accountancy

WO bedrijfskunde

WO informatica

WO juridisch

WO bestuurlijk

wo sociaal-cultureel

Wo kunst

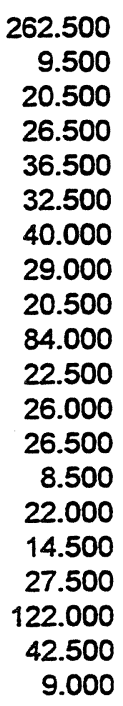

42.000

6.500

12.500

40.500

17.000

9.000

12.500

55.000

4.500

43.500

13.500

4.000

50.000

10.000

82.000

11.000 sterk stijgend

stijgend

stijgend

stijgend

stijgend

dalend

stijgend

sterk stijgend

stijgend

-

-

stijgend

stijgend

stijgend

dalend

-

stijgend

sterk dalend

stijgend

dalend

stijgend

-

sterk stijgend

Bron: CBS/ROA 
Tabel 3.3

Percentage vrouwen per opleidingstype, gemiddelde 1994-1995

Opleidingstype $\quad \% \quad$ typering trend

1993-'95

\section{BASISONDERWIS}

Basisonderwijs

MAVO, VBO

MAVO, onderbouw HAVOMWO

VBO landbouw en natuurlijke omgeving

VBO bouwtechniek

VBO installatietechniek

VBO mechanische techniek

VBO motorvoertuigentechniek

VBO elektrotechniek

VBO grafische techniek

VBO consumptieve techniek

VBO textiel- en ledertechniek

VBO haven en vervoer

VBO administratie

VBO verkoop en handel

VBO verzorging

VBO bewaking

HAVONWO, MBORLW

HAVONWO bovenbouw

MBORLW landbouw en natuurlijke omgeving

MBO technisch laboratorium

MBO/LLW bouwkunde

MBO/LLW weg-en waterbouwkunde

MBO/LLW metaalkunde

MBO/LLW fijnmechanische techniek

MBO/LLW werktuigbouwkunde

MBO/LLW motorvoertuigentechniek

MBO/LLW elektrotechniek

MBOILLW grafische techniek

MBO/LLW consumptieve techniek

MBO/LLW procestechniek

MBO/LW textiet en ledertechniek

MBOLLLW haven en vervoer

MBO/LLW verpleging en medische assistentie

MBO/LWW medisch laboratorium

MBO/LLW handel

MBO/LLW administratief

$M B O$ toerisme en recreatie

MBO/LLW commercieel

MBO/LLW secretarieel

MBO bestuurlijk-juridisch

MBO sociaal-cultureel

MBO/LLW verzorging

MBO/LLW horeca en uiterijke verzorging

MBO politie en defensie
29

gemiddeld

constant

gemiddeld

erg laag sterk stijgend

erg laag

erg laag

erg laag

erg laag

erg laag

erg laag

laag

erg hoog

erg laag

hoog

hoog

erg hoog

erg laag

gemiddeld

laag

gemiddeld

erg laag

erg laag

erg laag

laag

erg laag

erg laag

erg laag

laag

erg laag

erg laag

hoog

erg laag

erg hoog

hoog

gemiddeld

gemiddeld

erg hoog

gemiddeld

erg hoog

gemiddeld

hoog

erg hoog

gemiddeld

erg laag ster

sterk stijgend

-

-

constant

-

-

$-$ stijgend

sterk stijgend

sterk stijgend

sterk stijgend

sterk stijgend

sterk stijgend

sterk stijgend

sterk dalend

daiend

dalend

dalend

-

stijgend

constant

constant 
Tabel 3.3 (vervolg)

Percentage vrouwen per opleidingstype, gemiddelde 1994-1995

\begin{tabular}{llll}
\hline Opleidingstype & $\%$ & typering & $\begin{array}{c}\text { trend } \\
1993-95\end{array}$ \\
& & & \\
\hline
\end{tabular}

HBO

$\mathrm{HBO}$ onderwijs

$\mathrm{HBO}$ tolk en vertaler

HBO landbouw en milieukunde

HBO technisch laboratorium

HBO (weg- en water)bouwkunde

HBO werktuigbouwkunde

HBO elektrotechniek en technische informatica

$H B O$ haven en vervoer

HBO medisch laboratorium

$H B O$ verpleging en paramedisch

$\mathrm{HBO}$ bedrijfseconomie

HBO accountancy

HBO bedrijfsinformatica

HBO toerisme en recreatie

HBO commerciële economie

HBO technische bedrijfskunde

HBO bestuurlijk-juridisch

HBO sociaal-cultureel

HBO kunst

HBO politie en defensie

wo

Wo letteren

WO theologisch

WO landbouw en milieukunde

WO wiskunde en natuurwetenschappen

WO (weg- en water)bouwkunde

WO werktuigbouwkunde

WO elektrotechniek en technische informatica

WO dier-, genees- en tandheelkunde

WO farmacie

WO econom(etr)ie en accountancy

WO bedrijfskunde

WO informatica

wo juridisch

WO bestuurlijk

WO sociaal-cultureel

WO kunst

$\begin{array}{ll}\text { hoog } & \text { constant } \\ \text { hoog } & - \\ \text { laag } & - \\ \text { gemiddeld } & - \\ \text { erg laag } & \text { sterk stijgend } \\ \text { erg laag } & - \\ \text { erg laag } & \text { sterk stijgend } \\ \text { erg laag } & - \\ \text { hoog } & \text { stijgend } \\ \text { hoog } & \text { stijgend } \\ \text { laag } & \text { sterk stijgend } \\ \text { erg laag } & - \\ \text { laag } & \text { sterk stijgend } \\ \text { erg hoog } & - \\ \text { laag } & - \\ \text { erg laag } & - \\ \text { laag } & \text { stijgend } \\ \text { hoog } & \text { constant } \\ \text { gemiddeld } & \text { stijgend } \\ \text { erg laag } & -\end{array}$

gemiddeld dalend

laag sterk dalend

gemiddeld sterk stijgend

laag

$-$

$-$

$-$

$-$

sterk stijgend

stijgend

sterk stijgend

laag

erg laag

gemiddeld stijgend

laag sterk dalend

gemiddeld constant

gemiddeld

Bron: CBS/ROA 
Tabel 3.4

Percentage vrouwelijke werkzame schoolverlaters per opleidingsrichting, 1995

\begin{tabular}{|c|c|c|}
\hline Opleidingstype en -richting & $\%$ & typering \\
\hline \multicolumn{3}{|l|}{ MAVO, VBO } \\
\hline MAVO en onderbouw HAVOMWO & 47 & gemiddeld \\
\hline VBO land-en tuinbouw & 35 & laag \\
\hline \multicolumn{3}{|l|}{ VBO technisch } \\
\hline VBO bouwtechniek & 4 & erg laag \\
\hline VBO mechanische techniek & 3 & erg laag \\
\hline VBO motorvoertuigentechniek & . & - \\
\hline VBO elektrotechniek & 3 & erg laag \\
\hline VBO grafische techniek & & laag \\
\hline VBO consumptieve techniek & 23 & laag \\
\hline VBO textiel- en ledertechniek & $\cdot$ & hoog \\
\hline \multicolumn{3}{|l|}{ VBO economisch-administratief } \\
\hline VBO administratie & 62 & gemiddeld \\
\hline VBO verkoop en handel & 67 & gemiddeld \\
\hline \multicolumn{3}{|l|}{ VBO verzorgend } \\
\hline VBO verzorging & 98 & hoog \\
\hline VBO uiterlijke verzorging & $\cdot$ & erg hoog \\
\hline \multicolumn{3}{|l|}{ HAVONWO, MBO } \\
\hline \multicolumn{3}{|l|}{ HAVONWO bovenbouW } \\
\hline HAVO & 60 & gemiddeld \\
\hline Wwo & 49 & gemiddeld \\
\hline \multicolumn{3}{|c|}{ MBO landbouw en natuurijke omgeving } \\
\hline KMBO agrarisch & 52 & gemiddeld \\
\hline MBO plantenteelt & 13 & erg laag \\
\hline MBO veehouderij & 19 & laag \\
\hline MBO levensmiddelentechnologie & 62 & gemiddeld \\
\hline MBO bloemschikken & 82 & hoog \\
\hline MBO dierenverzorging & 89 & hoog \\
\hline MBO groene ruimte & 19 & laag \\
\hline \multicolumn{3}{|l|}{ MBO technisch laboratorium } \\
\hline MBO chemisch laboratorium & 33 & laag \\
\hline \multicolumn{3}{|l|}{ MBO technisch } \\
\hline KMBO motorvoertuigentechniek & & - \\
\hline KMBO elektrotechniek & $\therefore$ & - \\
\hline KMBO consumptieve techniek & 46 & gemiddeld \\
\hline MBO bouwkunde & 16 & laag \\
\hline MBO weg- en waterbouwkunde & 3 & erg laag \\
\hline MBO mechanische techniek & 4 & erg laag \\
\hline MBO werktuigbouwkunde & 3 & erg laag \\
\hline MBO motorvoertuigentechniek & . & erg laag \\
\hline MBO elektrotechniek & 4 & erg laag \\
\hline MBO textiel- en ledertechniek & 99 & erg hoog \\
\hline
\end{tabular}


Tabel 3.4 (vervolg)

Percentage vrouwelijke werkzame schoolverlaters per opleidingsrichting, 1995

\begin{tabular}{|c|c|c|}
\hline Opleidingstype en -richting & $\%$ & typering \\
\hline MBO haven en vervoer & 25 & laag \\
\hline \multicolumn{3}{|c|}{ MBO verpleging en medische assistentie } \\
\hline MBO verpl. en ziekenverzorging & 91 & hoog \\
\hline MBO assistent gezondheidszorg & 99 & erg hoog \\
\hline \multicolumn{3}{|l|}{ MBO economisch-administratief } \\
\hline KMBO detailhandel & 60 & gemiddeld \\
\hline KMBO administratie & 80 & hoog \\
\hline MBO handel & 55 & gemiddeld \\
\hline MBO administratie & 60 & gemiddeld \\
\hline MBO toerisme & 92 & hoog \\
\hline MBO commercieel & 64 & gemiddeld \\
\hline MBO secretarieel & 100 & erg hoog \\
\hline MBO bestuurlijk & . & gemiddeld \\
\hline MBO sociale arbeid & 87 & hoog \\
\hline \multicolumn{3}{|l|}{ MBO verzorgend } \\
\hline KMBO verzorging & 97 & hoog \\
\hline MBO agogisch werk & 96 & hoog \\
\hline MBO verzorging & 98 & hoog \\
\hline MBO mode en kleding & 100 & erg hoog \\
\hline MBO activiteitenbegeleiding & 95 & hoog \\
\hline \multicolumn{3}{|l|}{ MBO horeca en uiterlijke verzorging } \\
\hline MBO horeca & 51 & gemiddeld \\
\hline MBO facilitaire dienstverlening & 79 & hoog \\
\hline MBO uiterlijke verzorging & 99 & erg hoog \\
\hline \multicolumn{3}{|l|}{ HBO } \\
\hline \multicolumn{3}{|l|}{ HBO onderwijs } \\
\hline HBO basisondenwijzer & 90 & hoog \\
\hline HBO leraar agrarisch & 40 & gemiddeld \\
\hline HBO leraar kunst/expressie & 60 & gemiddeld \\
\hline HBO leraar voortgezet onderwijs & 70 & gemiddeld \\
\hline HBO tolk en vertaler & 86 & hoog \\
\hline HBO agrarisch & 28 & laag \\
\hline HBO technisch laboratorium & 50 & gemiddeld \\
\hline \multicolumn{3}{|l|}{ HBO technisch } \\
\hline HBO (weg- en water)bouwkunde & 14 & laag \\
\hline $\begin{array}{l}\text { HBO werktuigbouwkunde } \\
\text { HBO elektrotechiek }\end{array}$ & 5 & erg laag \\
\hline HBO elektrotechiek & 5 & erg laag \\
\hline HBO haven en vervoer & 11 & erg laag \\
\hline
\end{tabular}


Tabel 3.4 (vervolg)

Percentage vrouwelijke werkzame schoolverlaters per opleidingsrichting, 1995

\begin{tabular}{|c|c|c|}
\hline Opleidingstype en -richting & $\%$ & typering \\
\hline HBO medisch analist & 76 & hoog \\
\hline \multicolumn{3}{|l|}{ HBO verpleging en paramedisch } \\
\hline $\begin{array}{l}\text { HBO verpleegkunde } \\
\text { HBO (fusio-)therapie }\end{array}$ & 89 & hoog \\
\hline & & \\
\hline \multicolumn{3}{|l|}{ HBO economisch-administratief } \\
\hline HBO bedrijfseconomie & 36 & laag \\
\hline HBO accountancy & 28 & laag \\
\hline HBO bedrijfsinformatica & 13 & erg laag \\
\hline HBO toerisme & 84 & hoog \\
\hline HBO commerciële economie & 50 & gemiddeld \\
\hline HBO technische bedrijfskunde & 18 & laag \\
\hline HBO bestuurlijkJjuridisch & . & laag \\
\hline \multicolumn{3}{|l|}{ HBO sociaal-cultureel } \\
\hline HBO welzijnswerk/sociaal & 86 & hoog \\
\hline HBO personeelswerk & 70 & gemiddeld \\
\hline HBO journalistiek & 67 & gemiddeld \\
\hline HBO kunst & 55 & gemiddeld \\
\hline
\end{tabular}

Bron: RUBS/HBO-Monitor/ROA 


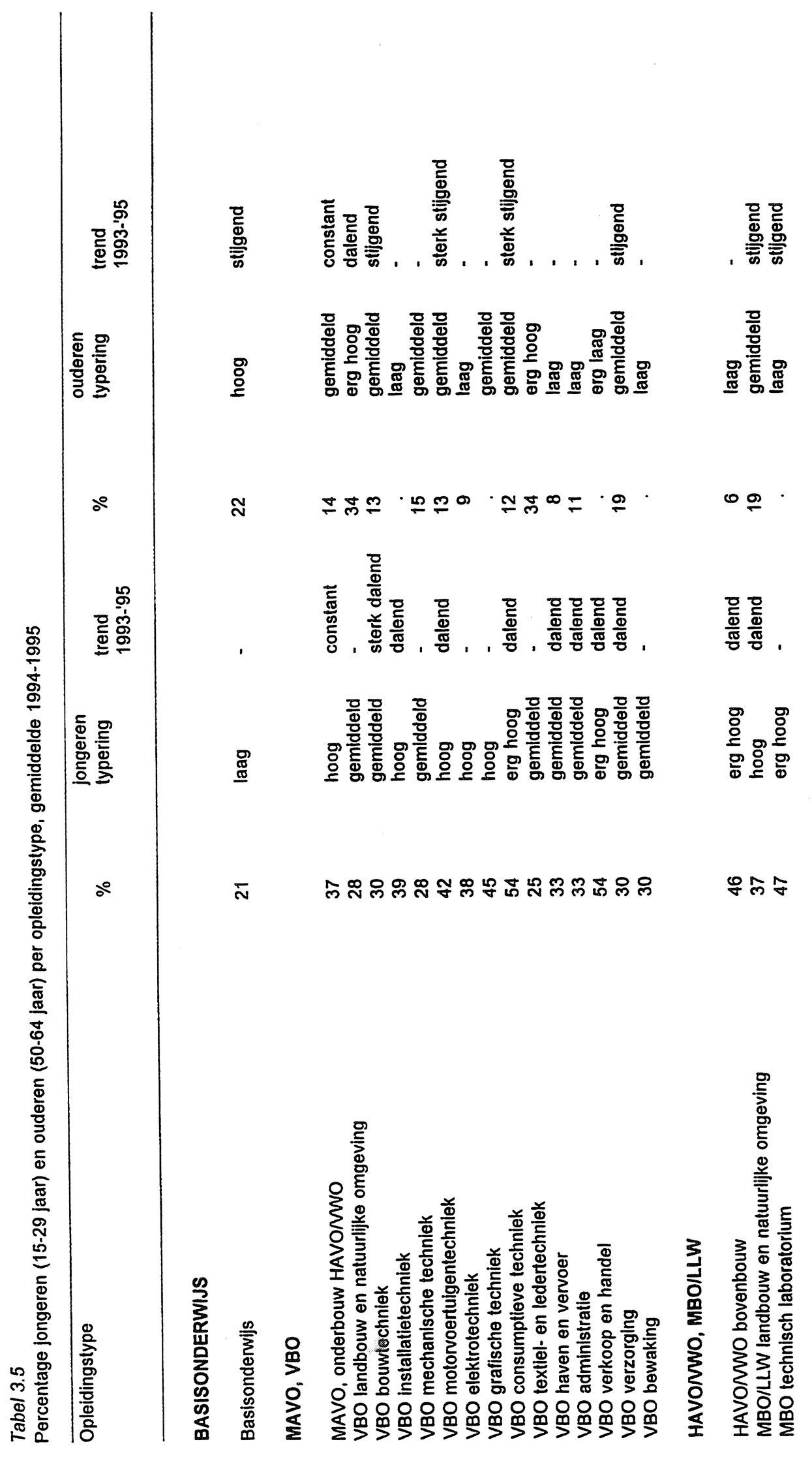









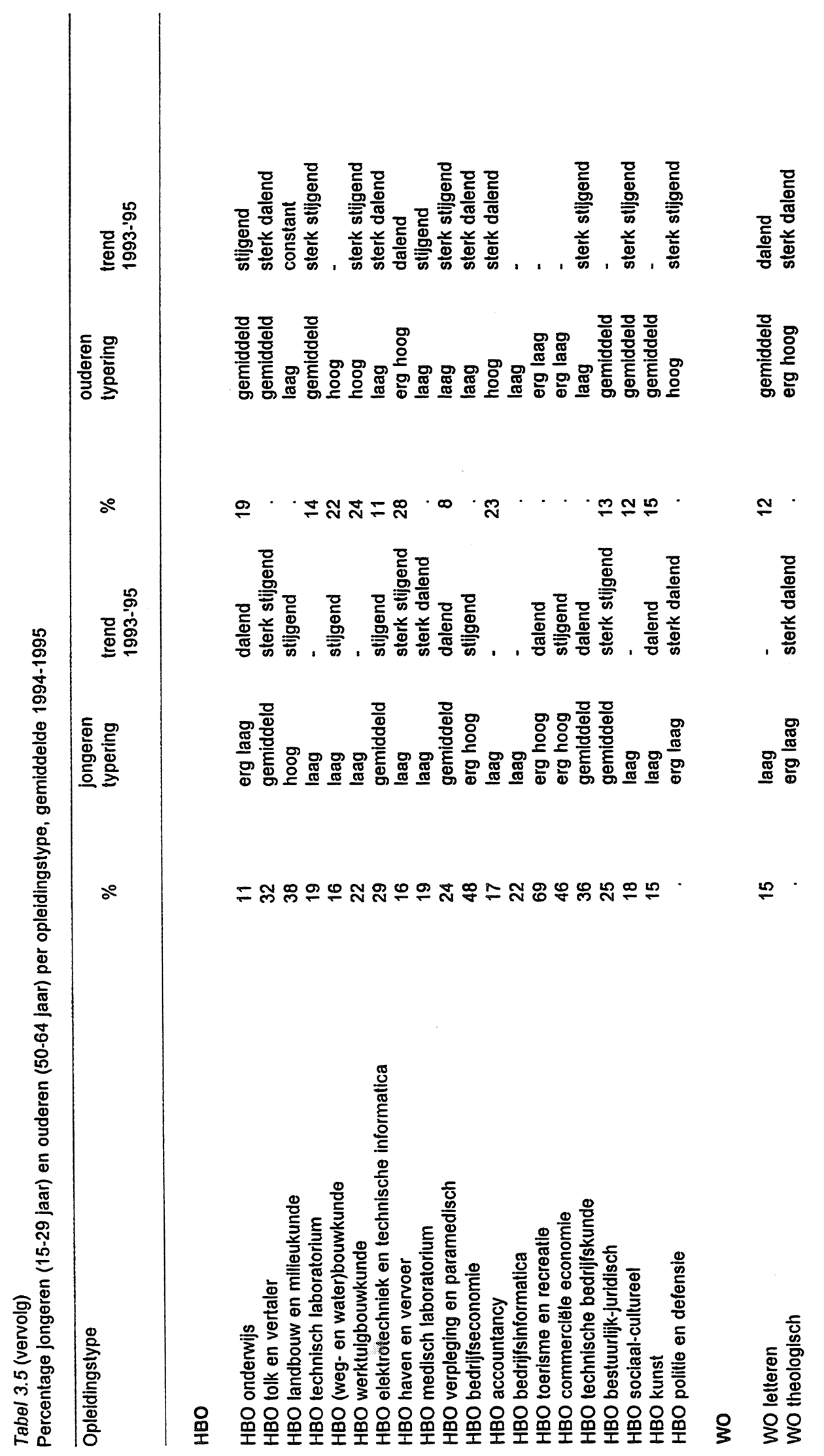




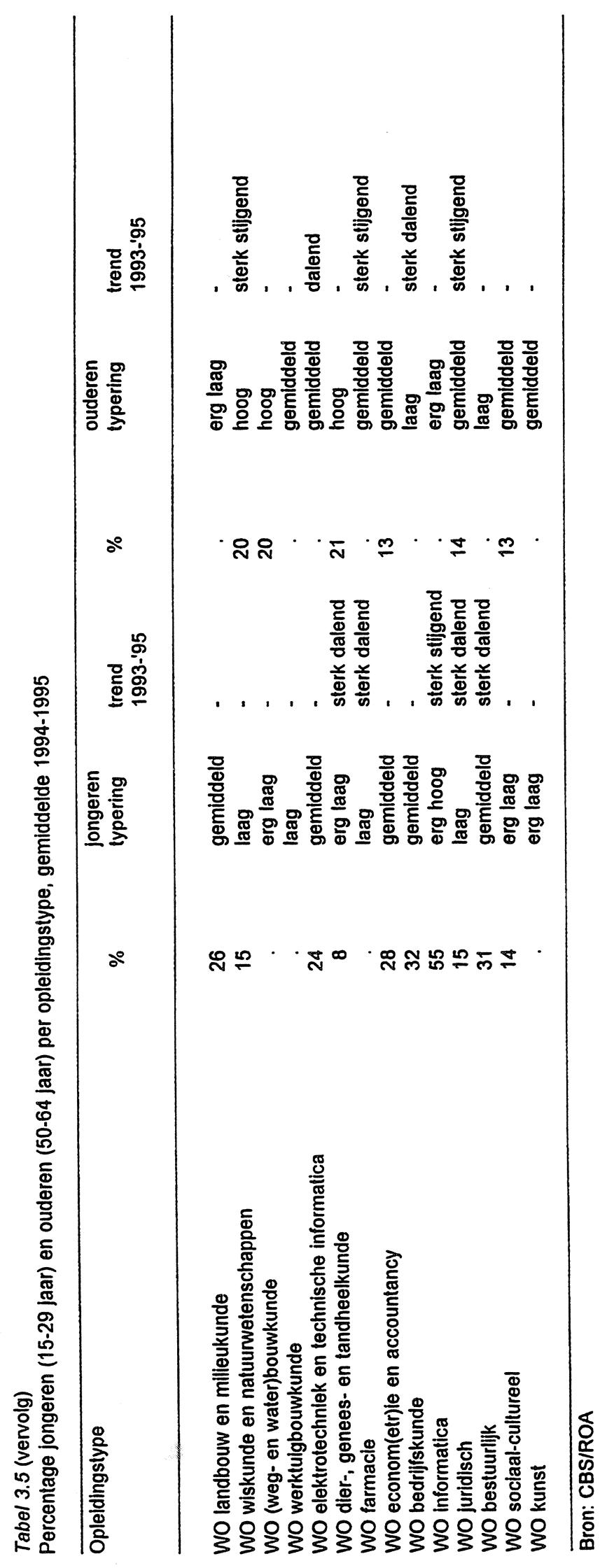


Tabel 3.6

Percentage allochtonen per opleidingstype, gemiddelde 1994-1995

\begin{tabular}{llll}
\hline Opleidingstype & $\%$ & typering & $\begin{array}{l}\text { trend } \\
1993-95\end{array}$ \\
& &
\end{tabular}

\section{BASISONDERWIJS}

Basisonderwijs

11

MAVO, VBO

MAVO, onderbouw HAVOMWO

VBO landbouw en natuurijike omgeving

VBO bouwtechniek

VBO installatietechniek

VBO mechanische techniek

VBO motorvoertuigentechniek

VBO elektrotechniek

VBO grafische techniek

VBO consumptieve techniek

VBO textiel- en ledertechniek

VBO haven en vervoer

VBO administratie

VBO verkoop en handel

VBO verzorging

VBO bewaking

HAVOMWO, MBOILLW

HAVOMWO bovenbouw

MBO/LLW landbouw en natuurlijke omgeving

MBO technisch laboratorium

MBO/LLW bouwkunde

MBO/LLW weg- en waterbouwkunde

MBO/LLW metaalkunde

MBO/LLW fijnmechanische techniek

MBO/LLW werktuigbouwkunde

MBOLLW motorvoertuigentechniek

MBO/LLW elektrotechniek

MBO/LLW grafische techniek

MBO/LLW consumptieve techniek

MBO/LLW procestechniek

MBORLW textiel- en ledertechniek

MBO/LLW haven en vervoer

MBO/LLW verpleging en medische assistentie

MBO/LLW medisch laboratorium

MBO/LLW handel

MBO/LLW administratief

MBO toerisme en recreatie

MBO/LLW commercieel

MBO/LLW secretarieel

MBO bestuurlijk-juridisch

MBO sociaal-cultureel

MBO/LLW verzorging

MBO/LLW horeca en uiterijke verzorging

$\mathrm{MBO}$ politie en defensie erg hoog

\begin{tabular}{ll} 
hoog & sterk stijgend \\
erg laag & - \\
laag & sterk dalend \\
hoog & - \\
gemiddeld & sterk dalend \\
hoog & sterk stijgend \\
gemiddeld & sterk dalend \\
erg laag & sterk dalend \\
erg laag & - \\
gemiddeld & sterk dalend \\
laag & - \\
gemiddeld & sterk dalend \\
gemiddeld & sterk stijgend \\
laag & sterk stijgend \\
\hline gemiddeld & -
\end{tabular}

gemiddeld stijgend

-

$-$

laag

erg laag

erg laag

gemiddeld

sterk dalend

erg laag

laag

laag

laag

laag

erg laag

gemiddeld

laag

erg laag

gemiddeld

laag

laag

gemiddeld

gemiddeld

erg laag

gemiddeld

gemiddeld

laag

laag

laag

laag stijgend

sterk dalend

-

sterk stijgend

-

sterk dalend

sterk stijgend

sterk stijgend

sterk dalend

sterk stijgend

sterk dalend

sterk dalend

sterk stijgend 
Tabel 3.6 (vervolg)

Percentage allochtonen per opleidingstype, gemiddelde 1994-1995

\begin{tabular}{|c|c|c|c|}
\hline Opleidingstype & $\%$ & typering & $\begin{array}{l}\text { trend } \\
1993-' 95\end{array}$ \\
\hline \multicolumn{4}{|l|}{ HBO } \\
\hline $\begin{array}{l}\text { HBO ondenwijs } \\
\text { HBO tolk en vertaler } \\
\text { HBO landbouw en milieukunde } \\
\text { HBO technisch laboratorium } \\
\text { HBO (weg- en water)bouwkunde } \\
\text { HBO werktuigbouwkunde } \\
\text { HBO elektrotechniek en technische informatica } \\
\text { HBO haven en vervoer } \\
\text { HBO medisch laboratorium } \\
\text { HBO verpleging en paramedisch } \\
\text { HBO bedrijfseconomie } \\
\text { HBO accountancy } \\
\text { HBO bedrijfsinformatica } \\
\text { HBO toerisme en recreatie } \\
\text { HBO commerciële economie } \\
\text { HBO technische bedrijfskunde } \\
\text { HBO bestuurlijk-juridisch } \\
\text { HBO sociaal-cultureel } \\
\text { HBO kunst } \\
\text { HBO politie en defensie }\end{array}$ & $\begin{array}{l}3 \\
\cdot \\
\cdot \\
\cdot \\
\cdot \\
. \\
\cdot \\
. \\
. \\
. \\
. \\
. \\
. \\
. \\
. \\
. \\
. \\
\\
. \\
.\end{array}$ & $\begin{array}{l}\text { gemiddeld } \\
\text { laag } \\
\text { erg laag } \\
\text { gemiddeld } \\
\text { erg laag } \\
\text { laag } \\
\text { laag } \\
\text { gemiddeld } \\
\text { laag } \\
\text { erg laag } \\
\text { gemiddeld } \\
\text { erg laag } \\
\text { erg laag } \\
\text { erg laag } \\
\text { erg laag } \\
\text { laag } \\
\text { laag } \\
\text { laag } \\
\text { laag } \\
\text { erg laag }\end{array}$ & $\begin{array}{l}\text { sterk dalend } \\
\text { - } \\
\text { - } \\
\text { sterk stijgend } \\
\text { - } \\
\text { stijgend } \\
\text { sterk stijgend } \\
\text { - } \\
\text { sterk dalend } \\
\text { - } \\
\text { sterk stijgend } \\
\text { sterk stijgend } \\
\text { - } \\
\text { - } \\
\text { - } \\
\text { sterk stijgend } \\
\text { - } \\
\text { - } \\
\text { stijgend } \\
\text { - }\end{array}$ \\
\hline \multicolumn{4}{|l|}{ wo } \\
\hline $\begin{array}{l}\text { WO letteren } \\
\text { WO theologisch } \\
\text { WO landbouw en milieukunde } \\
\text { WO wiskunde en natuurwetenschappen } \\
\text { WO (weg- en water)bouwkunde } \\
\text { WO werktuigbouwkunde } \\
\text { WO elektrotechniek en technische informatica } \\
\text { WO dier-, genees- en tandheelkunde } \\
\text { WO farmacie } \\
\text { WO econom(etr)ie en accountancy } \\
\text { WO bedrijfskunde } \\
\text { WO informatica } \\
\text { WO juridisch } \\
\text { WO bestuurlijk } \\
\text { WO sociaal-cultureel } \\
\text { WO kunst }\end{array}$ & $\begin{array}{l}\cdot \\
\cdot \\
\cdot \\
\cdot \\
\cdot \\
\cdot \\
\cdot \\
. \\
. \\
. \\
. \\
. \\
. \\
. \\
. \\
.\end{array}$ & $\begin{array}{l}\text { erg laag } \\
\text { erg laag } \\
\text { gemiddeld } \\
\text { erg laag } \\
\text { laag } \\
\text { laag } \\
\text { gemiddeld } \\
\text { laag } \\
\text { gemiddeld } \\
\text { laag } \\
\text { laag } \\
\text { gemiddeld } \\
\text { erg laag } \\
\text { erg laag } \\
\text { gemiddeld } \\
\text { erg laag }\end{array}$ & $\begin{array}{l}\text { - } \\
\text { - } \\
\text { - } \\
\text { sterk stijgend } \\
\text { - } \\
\text { - } \\
\text { - } \\
\text { - } \\
\text { - } \\
\text { - } \\
\text { - } \\
\text { sterk dalend } \\
\text { - } \\
\text { - } \\
\text { - }\end{array}$ \\
\hline
\end{tabular}

Bron: CBS/ROA

- Het percentage heeft betrekking op allochtonen uit de landen die vallen onder de WBEAA. 
Tabel 3.7

Percentage allochtone werkzame schoolverlaters per opleidingsrichting, 1995

\begin{tabular}{lll}
\hline Opleidingstype en -richting & $\%$ & typering \\
\hline
\end{tabular}

MAVO, VBO

MAVO en onderbouW HAVOMWO

VBO land- en tuinbouw

VBO technisch

VBO bouwtechniek

VBO mechanische techniek

VBO motorvoertuigentechniek

VBO elektrotechniek

VBO grafische techniek

VBO consumptieve techniek

VBO textiel- en ledertechniek

VBO economisch-administratief

VBO administratie

VBO verkoop en handel

VBO verzorgend

VBO verzorging

VBO uiterlijke verzorging

HAVONWO, MBO

HAVOMWO bovenbouW

HAVO

WWO

MBO landbouw en natuurlijke omgeving

KMBO agrarisch

MBO plantenteelt

$M B O$ veehouderij

MBO levensmiddelentechnologie

MBO bloemschikken

MBO dierenverzorging

MBO groene ruimte

MBO technisch laboratorium

MBO chemisch laboratorium

MBO technisch

KMBO motorvoertuigentechniek

KMBO elektrotechniek

KMBO consumptieve techniek

MBO bouwkunde

MBO weg-en waterbouwkunde

MBO mechanische techniek

MBO werktuigbouwkunde

MBO motorvoertuigentechniek

MBO elektrotechniek

MBO textiel- en ledertechniek
2

2

1

gemiddeld

laag

erg hoog

.

laag

gemiddeld

gemiddeld

gemiddeld

3

-

laag

-

-

$-$

-

laag

hoog

hoog

-

erg hoog

-

laag

laag 
Tabel 3.7 (vervolg)

Percentage allochtone werkzame schoolverlaters per opleidingsrichting, 1995

\begin{tabular}{|c|c|c|}
\hline Opleidingstype en -richting & $\%$ & typering \\
\hline MBO haven en vervoer & . & - \\
\hline \multicolumn{3}{|c|}{ MBO verpleging en medische assistentie } \\
\hline MBO verpl. en ziekenverzorging & . & - \\
\hline MBO assistent gezondheidszorg & 3 & gemiddeld \\
\hline \multicolumn{3}{|l|}{ MBO economisch-administratief } \\
\hline KMBO detailhandel & 8 & erg hoog \\
\hline KMBO administratie & 10 & erg hoog \\
\hline MBO handel & 1 & laag \\
\hline MBO administratie & 1 & laag \\
\hline MBO toerisme & 1 & laag. \\
\hline MBO commercieel & 3 & gemiddeld \\
\hline MBO secretarieel & 3 & gemiddeld \\
\hline MBO bestuurijk & $\cdot$ & erg hoog \\
\hline MBO sociale arbeid & 6 & erg hoog \\
\hline \multicolumn{3}{|l|}{ MBO verzorgend } \\
\hline KMBO verzorging & 2 & gemiddeld \\
\hline MBO agogisch werk & 1 & laag \\
\hline MBO verzorging & . & erg laag \\
\hline MBO mode en kleding & - & - \\
\hline MBO activiteitenbegeleiding & $\cdot$ & - \\
\hline \multicolumn{3}{|l|}{ MBO horeca en uiterlijke verzorging } \\
\hline MBO horeca & - & - \\
\hline MBO facilitaire dienstverlening & $\cdot$ & - \\
\hline MBO uiterlijke verzorging & $\cdot$ & - \\
\hline \multicolumn{3}{|l|}{ HBO } \\
\hline \multicolumn{3}{|l|}{ HBO onderwijs } \\
\hline HBO basisonderwijzer & 1 & laag \\
\hline HBO leraar agrarisch & $\cdot$ & - \\
\hline HBO leraar kunstlexpressie & $\cdot$ & - \\
\hline HBO leraar voortgezet ondenwijs & · & erg laag \\
\hline HBO tolk en vertaler & $\cdot$ & - \\
\hline HBO agrarisch & $\cdot$ & - \\
\hline HBO technisch laboratorium & 2 & gemiddeld \\
\hline \multicolumn{3}{|l|}{ HBO technisch } \\
\hline $\begin{array}{l}\text { HBO (weg- en water)bouwkunde } \\
\text { HBO werktuigbouwkunde }\end{array}$ & 1 & $\begin{array}{l}\text { erg laag } \\
\text { laag }\end{array}$ \\
\hline HBO elektrotechiek & 2 & gemiddeld \\
\hline
\end{tabular}

HBO haven en vervoer 
Tabel 3.7 (vervolg)

Percentage allochtone werkzame schoolverlaters per opleidingsrichting, 1995

\begin{tabular}{|c|c|c|}
\hline Opleidingstype en -richting & $\%$ & typering \\
\hline HBO medisch analist & . & - \\
\hline \multicolumn{3}{|l|}{ HBO verpleging en paramedisch } \\
\hline HBO verpleegkunde & 1 & laag \\
\hline HBO (fysio-)therapie & $\cdot$ & - \\
\hline \multicolumn{3}{|l|}{ HBO economisch-administratief } \\
\hline HBO bedrijfseconomie & 1 & laag \\
\hline HBO accountancy & 1 & laag \\
\hline HBO bedrijfsinformatica & 2 & gemiddeld \\
\hline HBO toerisme & · & erg laag \\
\hline HBO commerciële economie & 1 & laag \\
\hline HBO technische bedrijfskunde & 1 & laag \\
\hline HBO bestuurlijkjuridisch & . & erg hoog \\
\hline \multicolumn{3}{|l|}{ HBO sociaal-cultureel } \\
\hline HBO welzijnswerk/sociaal & 2 & gemiddeld \\
\hline HBO personeelswerk & 1 & laag \\
\hline HBO joumalistiek & 1 & laag \\
\hline HBO kunst & . & erg laag \\
\hline
\end{tabular}

Bron: RUBS/HBO-Monitor/ROA

- Het percentage heeft betrekking op allochtonen uit de landen die vallen onder de WBEAA. 
Tabel 3.8

Deeltijdarbeid per opleidingstype, gemiddelde 1994-1995

\begin{tabular}{llll}
\hline Opleidingstype & $\%$ & typering & trend \\
& & & $1993-95$
\end{tabular}

\section{BASISONDERWIJS}

Basisonderwijs

MAVO, VBO

MAVO, onderbouw HAVONWO

VBO landbouw en natuurlijke omgeving

VBO bouwtechniek

VBO installatietechniek

VBO mechanische techniek

VBO motorvoertuigentechniek

VBO elektrotechniek

VBO grafische techniek

VBO consumptieve techniek

VBO textiel- en ledertechniek

VBO haven en vervoer

VBO administratie

VBO verkoop en handel

VBO verzorging

VBO bewaking

\section{HAVONWO, MBORLW}

HAVONWO bovenbouw

MBO/LLW landbouw en natuurlijke omgeving

MBO technisch laboratorium

MBO/LLW bouwkunde

MBOLLWW weg- en waterbouwkunde

MBO/LLW metaalkunde

MBO/LLW fijnmechanische techniek

MBO/LLW werktuigbouwkunde

MBO/LLW motorvoertuigentechniek

MBORLW elektrotechniek

MBORLW grafische techniek

MBO/LLW consumptieve techniek

MBO/LLW procestechniek

MBO/LLW textiel- en ledertechniek

MBO/LLW haven en vervoer

MBO/LLW verpleging en medische assistentie

MBO/LLW medisch laboratorium

MBO/LLW handel

MBO/LLW administratief

MBO toerisme en recreatie

MBOLLWW commercieel

MBO/LLW secretarieel

MBO bestuurlijk-juridisch

MBO sociaal-cultureel

MBO/LLW verzorging

MBO/LW horeca en uiterlijke verzorging

MBO politie en defensie
26

gemiddeld

stijgend

$\begin{array}{ll}\text { gemiddeld } & \begin{array}{l}\text { stijgend } \\ \text { laag }\end{array} \\ \begin{array}{l}\text { sterk stijgend } \\ \text { dalend } \\ \text { laag }\end{array} & \text { sterk stijgend } \\ \text { laag } & \text { stijgend } \\ \text { laag } & \text { sterk dalend } \\ \text { laag } & \text { sterk stijgend } \\ \text { laag } & - \\ \text { laag } & - \\ \text { gemiddeld } & \text { stijgend } \\ \text { erg hoog } & \text { sterk stijgend } \\ \text { laag } & - \\ \text { hoog } & - \\ \text { hoog } & \text { constant } \\ \text { erg hoog } & -\end{array}$

gemiddeld

laag

gemiddeld sterk stijgend

erg laag sterk stijgend

erg laag sterk dalend

erg laag sterk stijgend

laag

erg laag

erg laag

erg laag

laag

laag

laag

hoog

laag

erg hoog

hoog

gemiddeld

laag

gemiddeld

laag

hoog

sterk stijgend

sterk stijgend

stijgend

sterk stijgend

sterk stijgend

stijgend

stijgend

stijgend

sterk stijgend

stijgend

hoog stijgend

gemiddeld stijgend 
Tabel 3.8 (vervolg)

Deeltijdarbeid per opleidingstype, gemiddelde 1994-1995

\begin{tabular}{llll}
\hline Opleidingstype & $\%$ & typering & $\begin{array}{c}\text { trend } \\
1993-95\end{array}$ \\
& & & \\
\hline
\end{tabular}

HBO

$\mathrm{HBO}$ onderwijs

HBO tolk en vertaler

$H B O$ landbouw en milieukunde

48

12

HBO technisch laboratorium

HBO (weg-en water)bouwkunde

$\mathrm{HBO}$ werktuigbouwkunde

HBO elektrotechniek en technische informatica

HBO haven en vervoer

HBO medisch laboratorium

$H B O$ verpleging en paramedisch

$\mathrm{HBO}$ bedrijfseconomie

HBO accountancy

HBO bedrijfsinformatica

$\mathrm{HBO}$ toerisme en recreatie

HBO commerciële economie

$H B O$ technische bedrijfskunde

HBO bestuurlijk-juridisch

HBO sociaal-cultureel

HBO kunst

HBO politie en defensie

\section{wo}

wo letteren

WO theologisch

WO landbouw en milieukunde

WO wiskunde en natuurwetenschappen

WO (weg- en water)bouwkunde

WO werktuigbouwkunde

WO elektrotechniek en technische informatica

WO dier-, genees- en tandheelkunde

WO farmacie

WO econom(etr)ie en accountancy

WO bedrijfskunde

WO informatica

WO juridisch

WO bestuurijik

WO sociaal-cultureel

wo kunst gemiddeld

hoog

laag

constant

sterk stijgend

sterk stijgend

sterk stijgend

laag

erg laag

erg laag

laag

hoog

erg hoog

laag

erg laag

laag

gemiddeld

erg laag

erg laag

laag

hoog

hoog

erg laag

sterk stijgend

stijgend

sterk stijgend

sterk stijgend

sterk stijgend

-

sterk stijgend

stijgend

stijgend

sterk dalend

$\begin{array}{ll}\text { hoog } & \text { stijgend } \\ \text { gemiddeld } & - \\ \text { gemiddeld } & \text { sterk stijgend } \\ \text { gemiddeld } & \text { stijgend } \\ \text { laag } & \text { sterk stijgend } \\ \text { erg laag } & - \\ \text { erg laag } & - \\ \text { gemiddeld } & - \\ \text { laag } & - \\ \text { laag } & \text { sterk dalend } \\ \text { laag } & \text { sterk stijgend } \\ \text { laag } & \text { sterk stijgend } \\ \text { gemiddeld } & \text { sterk stijgend } \\ \text { laag } & - \\ \text { hoog } & \text { stijgend } \\ \text { hoog } & -\end{array}$

Bron: CBS/ROA 
Tabel 3.9

Deeltijdarbeid onder werkzame schoolverlaters per opleidingsrichting, 1995

\begin{tabular}{|c|c|c|}
\hline Opleidingstype en -richting & $\%$ & typering \\
\hline \multicolumn{3}{|l|}{ MAVO, VBO } \\
\hline MAVO en onderbouW HAVOMWO & 61 & hoog \\
\hline VBO land-en tuinbouw & 62 & hoog \\
\hline \multicolumn{3}{|l|}{ VBO technisch } \\
\hline VBO bouwtechniek & 50 & gemiddeld \\
\hline VBO mechanische techniek & 47 & gemiddeld \\
\hline VBO motorvoertuigentechniek & 77 & erg hoog \\
\hline VBO elektrotechniek & 44 & gemiddeld \\
\hline VBO grafische techniek &. & gemiddeld \\
\hline VBO consumptieve techniek & 69 & hoog \\
\hline VBO textiel- en ledertechniek & $\cdot$ & gemiddeld \\
\hline \multicolumn{3}{|l|}{ VBO economisch-administratief } \\
\hline VBO administratie & 78 & erg hoog \\
\hline VBO verkoop en handel & 67 & hoog \\
\hline \multicolumn{3}{|l|}{ VBO verzorgend } \\
\hline VBO verzorging & 63 & hoog \\
\hline VBO uiterlijke verzorging & - & hoog \\
\hline \multicolumn{3}{|l|}{ HAVONWO, MBO } \\
\hline \multicolumn{3}{|l|}{ HAVOMWO bovenbouw } \\
\hline HAVO & 59 & hoog \\
\hline wo & 66 & hoog \\
\hline \multicolumn{3}{|l|}{ MBO landbouw en natuurlijke omgeving } \\
\hline KMBO agrarisch & 36 & gemiddeld \\
\hline MBO plantenteelt & 14 & laag \\
\hline MBO veehouderij & 24 & gemiddeld \\
\hline MBO levensmiddelentechnologie & 15 & gemiddeld \\
\hline MBO bloemschikken & 34 & gemiddeld \\
\hline MBO dierenverzorging & 49 & gemiddeld \\
\hline MBO groene ruimte & 16 & gemiddeld \\
\hline \multicolumn{3}{|l|}{ MBO technisch laboratorium } \\
\hline MBO chemisch laboratorium & 4 & erg laag \\
\hline \multicolumn{3}{|l|}{ MBO technisch } \\
\hline KMBO motorvoertuigentechniek & 54 & gemiddeld \\
\hline KMBO elektrotechniek & 17 & gemiddeld \\
\hline KMBO consumptieve techniek & 57 & hoog \\
\hline MBO bouwkunde & 9 & laag \\
\hline MBO weg-en waterbouwkunde & - & - \\
\hline MBO mechanische techniek & 4 & erg laag \\
\hline MBO werktuigbouwkunde & 10 & laag \\
\hline MBO motorvoertuigentechniek & 1 & erg laag \\
\hline MBO elektrotechniek & 11 & laag \\
\hline MBO textiel- en ledertechniek & 46 & gemiddeld \\
\hline
\end{tabular}


Tabel 3.9 (vervolg)

Deeltijdarbeid onder werkzame schoolverlaters per opleidingsrichting, 1995

\begin{tabular}{|c|c|c|}
\hline Opleidingstype en -richting & $\%$ & typering \\
\hline MBO haven en vervoer & 11 & laag \\
\hline $\begin{array}{l}\text { MBO verpleging en medische assist } \\
\text { MBO verpl. en ziekenverzorging } \\
\text { MBO assistent gezondheidszorg }\end{array}$ & $\begin{array}{l}36 \\
30\end{array}$ & $\begin{array}{l}\text { gemiddeld } \\
\text { gemiddeld }\end{array}$ \\
\hline $\begin{array}{l}\text { MBO economisch-administratief } \\
\text { KMBO detailhandel } \\
\text { KMBO administratie } \\
\text { MBO handel } \\
\text { MBO administratie } \\
\text { MBO toerisme } \\
\text { MBO commercieel } \\
\text { MBO secretarieel }\end{array}$ & $\begin{array}{l}35 \\
31 \\
35 \\
20 \\
16 \\
19 \\
19\end{array}$ & $\begin{array}{l}\text { gemiddeld } \\
\text { gemiddeld } \\
\text { gemiddeld } \\
\text { gemiddeld } \\
\text { gemiddeld } \\
\text { gemiddeld } \\
\text { gemiddeld }\end{array}$ \\
\hline MBO bestuurlijk & 10 & laag \\
\hline MBO sociale arbeid & 41 & gemiddeld \\
\hline $\begin{array}{l}\text { MBO verzorgend } \\
\text { KMBO verzorging } \\
\text { MBO agogisch werk } \\
\text { MBO verzorging } \\
\text { MBO mode en kleding } \\
\text { MBO activiteitenbegeleiding }\end{array}$ & $\begin{array}{l}59 \\
57 \\
45 \\
43 \\
71\end{array}$ & $\begin{array}{l}\text { hoog } \\
\text { hoog } \\
\text { gemiddeld } \\
\text { gemiddeld } \\
\text { hoog }\end{array}$ \\
\hline $\begin{array}{l}\text { MBO horeca en uiterlijke verzorging } \\
\text { MBO horeca } \\
\text { MBO facilitaire dienstverlening } \\
\text { MBO uiterlijke verzorging }\end{array}$ & $\begin{array}{l}18 \\
52 \\
60\end{array}$ & $\begin{array}{l}\text { gemiddeld } \\
\text { gemiddeld } \\
\text { hoog }\end{array}$ \\
\hline HBO & & \\
\hline $\begin{array}{l}\text { HBO onderwijs } \\
\text { HBO basisonderwijzer } \\
\text { HBO leraar agrarisch } \\
\text { HBO leraar kunst/expressie } \\
\text { HBO leraar voortgezet onderwijs }\end{array}$ & $\begin{array}{l}28 \\
31 \\
78 \\
40\end{array}$ & $\begin{array}{l}\text { gemiddeld } \\
\text { gemiddeld } \\
\text { erg hoog } \\
\text { gemiddeld }\end{array}$ \\
\hline HBO tolk en vertaler & 30 & gemiddeld \\
\hline HBO agrarisch & 11 & laag \\
\hline HBO technisch laboratorium & 7 & erg laag \\
\hline $\begin{array}{l}\text { HBO technisch } \\
\text { HBO (weg- en water)bouwkunde } \\
\text { HBO werktuigbouwkunde } \\
\text { HBO elektrotechiek }\end{array}$ & $\begin{array}{l}5 \\
2 \\
3\end{array}$ & $\begin{array}{l}\text { erg laag } \\
\text { erg laag } \\
\text { erg laag }\end{array}$ \\
\hline HBO haven en vervoer & 2 & erg laag \\
\hline
\end{tabular}


Tabel 3.9 (vervolg)

Deeltijdarbeid onder werkzame schoolverlaters per opleidingsrichting, 1995

Opleidingstype en -richting

HBO medisch analist

HBO verpleging en paramedisch

$\mathrm{HBO}$ verpleegkunde

HBO (fysio-)therapie

$H B O$ economisch-administratief

$\mathrm{HBO}$ bedrijfseconomie

HBO accountancy

HBO bedrijfsinformatica

$\mathrm{HBO}$ toerisme

HBO commerciële economie

HBO technische bedrijfskunde

HBO bestuurlijkJuridisch

HBO sociaal-cultureel

HBO welzijnswerk/sociaal

HBO personeelswerk

HBO journalistiek

HBO kunst

Bron: RUBS/HBO-Monitor/ROA
$\%$

typering

laag

48

gemiddeld

gemiddeld

laag

laag

erg laag

gemiddeld

laag

erg laag

gemiddeld

hoog

gemiddeld

gemiddeld

44

gemiddeld 
Tabel 3.10

Zelfstandigen per opleidingstype, gemiddelde 1994-1995

\begin{tabular}{|c|c|c|c|}
\hline Opleidingstype & $\%$ & typering & $\begin{array}{l}\text { trend } \\
1993-' 95\end{array}$ \\
\hline
\end{tabular}

\section{BASISONDERWIS}

Basisondenwijs

MAVO, VBO

MAVO, onderbouw HAVONWO

VBO landbouw en natuurijke omgeving

VBO bouwtechniek

VBO installatietechniek

VBO mechanische techniek

VBO motorvoertuigentechniek

VBO elektrotechniek

VBO grafische techniek

VBO consumptieve techniek

VBO textiel- en ledertechniek

VBO haven en vervoer

VBO administratie

VBO verkoop en handel

VBO verzorging

VBO bewaking

\section{HAVONWO, MBORLW}

HAVONWO bovenbouw

MBO/LLW landbouw en natuurlijke omgeving

MBO technisch laboratorium

MBO/LLW bouwkunde

MBO/LLW weg-en waterbouwkunde

MBO/LLW metaalkunde

MBO/LLW fijnmechanische techniek

MBO/LLW werktuigbouwkunde

MBO/LLW motorvoertuigentechniek

MBO/LLW elektrotechniek

MBO/LLW grafische techniek

MBO/LLW consumptieve techniek

MBO/LLW procestechniek

MBO/LLW textiel- en ledertechniek

MBO/LLW haven en vervoer

MBO/LLW verpleging en medische assistentie

MBO/LLW medisch laboratorium

MBO/LLW handel

MBO/LLW administratief

MBO toerisme en recreatie

MBO/LLW commercieel

MBO/LLW secretarieel

MBO bestuurlijk-juridisch

MBO sociaal-cultureel

MBO/LLW verzorging

MBO/LLW horeca en uiterlijke verzorging

MBO politie en defensie gemiddeld

\begin{tabular}{|c|c|}
\hline $\begin{array}{l}\text { gemiddeld } \\
\text { erg hoog } \\
\text { laag } \\
\text { erg laag } \\
\text { laag } \\
\text { laag } \\
\text { erg laag } \\
\text { laag } \\
\text { laag } \\
\text { gemiddeld } \\
\text { laag } \\
\text { gemiddeld } \\
\text { gemiddeld } \\
\text { gemiddeld } \\
\text { erg laag }\end{array}$ & 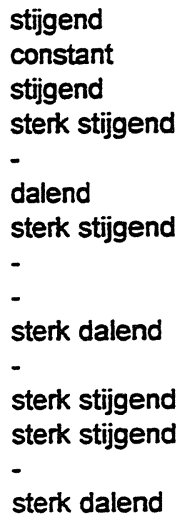 \\
\hline
\end{tabular}

gemiddeld -

erg hoog -

erg laag sterk stijgend

gemiddeld -

erg laag -

erg laag dalend

gemiddeld sterk dalend

laag sterk stijgend

gemiddeld dalend

erg laag

gemiddeld stijgend

hoog

erg laag sterk dalend

hoog sterk stijgend

gemiddeld -

erg laag -

gemiddeld dalend

hoog

erg laag

erg laag

gemiddeld

erg laag

erg laag

erg laag

gemiddeld

erg hoog

erg laag
-

$-$

sterk stijgend

sterk dalend sterk stijgend dalend sterk stijgend 
Tabel 3.10 (vervolg)

Zelfstandigen per opleidingstype, gemiddelde 1994-1995

\begin{tabular}{llll}
\hline Opleidingstype & $\%$ & typering & $\begin{array}{l}\text { trend } \\
1993-95\end{array}$
\end{tabular}

HBO

$\mathrm{HBO}$ onderwijs

HBO tolk en vertaler

HBO landbouw en milieukunde

HBO technisch laboratorium

HBO (weg-en water)bouwkunde

HBO werktuigbouwkunde

HBO elektrotechniek en technische informatica

$H B O$ haven en vervoer

HBO medisch laboratorium

$H B O$ verpleging en paramedisch

HBO bedrijfseconomie

HBO accountancy

HBO bedrijfsinformatica

$\mathrm{HBO}$ toerisme en recreatie

HBO commerciële economie

$\mathrm{HBO}$ technische bedrijfskunde

HBO bestuurilik-juridisch

HBO sociaal-cultureel

HBO kunst

HBO politie en defensie

$\begin{array}{rll}5 & \text { erg laag } & - \\ 21 & \text { hoog } & - \\ 21 & \text { hoog } & - \\ . & \text { erg laag } & \text { sterk dalend } \\ 9 & \text { gemiddeld } & - \\ 10 & \text { gemiddeld } & \text { sterk stijgend } \\ 6 & \text { laag } & - \\ 9 & \text { gemiddeld } & \text { sterk stijgend } \\ . . & \text { erg laag } & \text { sterk dalend } \\ 18 & \text { hoog } & \text { dalend } \\ 12 & \text { laag } & \text { sterk stijgend } \\ . & \text { gemiddeld } & \text { stijgend } \\ . & \text { laag } & \text { sterk stijgend } \\ . & \text { erg laag } & - \\ . & \text { laag } & - \\ 9 & \text { laag } & - \\ 6 & \text { gemiddeld } & - \\ 43 & \text { laag } & \text { dalend } \\ . & \text { erg hoog } & - \\ & \text { erg laag } & \text { sterk stijgend }\end{array}$

\section{wo}

Wo letteren

WO theologisch

WO landbouw en milieukunde

WO wiskunde en natuurwetenschappen

WO (weg- en water)bouwkunde

WO werktuigbouwkunde

WO elektrotechniek en technische informatica

WO dier-, genees- en tandheelkunde

WO farmacie

WO econom(etr)ie en accountancy

WO bedrijfskunde

WO informatica

WO juridisch

WO bestuurlijk

WO sociaal-cultureel

WO kunst

\begin{tabular}{rll}
11 & gemiddeld & - \\
. & erg hoog & stijgend \\
. & erg laag & - \\
erg laag & - \\
17 & hoog & - \\
. & erg laag & - \\
. & laag & - \\
38 & erg hoog & dalend \\
12 & erg hoog & sterk dalend \\
\hline & gemiddeld & - \\
. & gemiddeld & sterk dalend \\
17 & laag & sterk stijgend \\
. & hoog & - \\
8 & gemiddeld & - \\
. & laag & stijgend \\
\hline & hoog & sterk dalend
\end{tabular}

Bron: CBS/ROA

- Inclusief personen die werkzaam zijn in het bedrijf of de praktijk van hun partner of ouders en freelancers e.d. 
Tabel 3.11

Flexibel werk per opleidingstype, gemiddelde 1994-1995

\begin{tabular}{|c|c|c|c|}
\hline Opleidingstype & $\%$ & typering & $\begin{array}{l}\text { trend } \\
1993-95\end{array}$ \\
\hline
\end{tabular}

\section{BASISONDERWIJS}

Basisonderwijs

MAVO, VBO

MAVO, onderbouw HAVOMWO

VBO landbouw en natuurlijke omgeving

VBO bouwtechniek

VBO installatietechniek

VBO mechanische techniek

VBO motorvoertuigentechniek

VBO elektrotechniek

VBO grafische techniek

VBO consumptieve techniek

VBO textiel- en ledertechniek

VBO haven en vervoer

VBO administratie

VBO verkoop en handel

VBO verzorging

VBO bewaking

\section{HAVONWO, MBORLW}

HAVONWO bovenbouw

MBO/LLW landbouw en natuurlijke omgeving

MBO technisch laboratorium

MBO/LLW bouwkunde

MBORLW weg- en waterbouwkunde

MBO/LLW metaalkunde

MBO/LLW fijnmechanische techniek

MBO/LLW werktuigbouwkunde

MBO/LLW motorvoertuigentechniek

MBO/LLW elektrotechniek

MBO/LLW grafische techniek

MBO/LLW consumptieve techniek

MBO/LLW procestechniek

MBO/LLW textiel- en ledertechniek

MBO/LLW haven en vervoer

MBO/LLW verpleging en medische assistentie

MBO/LLW medisch laboratorium

MBO/LLW handel

MBO/LLW administratief

MBO toerisme en recreatie

MBO/LLW commercieel

MBO/LLW secretarieel

MBO bestuurlijk-juridisch

MBO sociaal-cultureel

MBO/LLW verzorging

MBO/LLW horeca en uiterlijke verzorging

MBO politie en defensie gemiddeld

sterk stijgend

$\begin{array}{ll}\text { erg hoog } & \begin{array}{l}\text { stijgend } \\ \text { stijgend } \\ \text { laag }\end{array} \\ \text { laag } & \text { stijgend } \\ \text { gemiddeld } & \text { sterk stijgend } \\ \text { gemiddeld } & \text { sterk stijgend } \\ \text { gemiddeld } & \text { - } \\ \text { gemiddeld } & \text { - } \\ \text { gemiddeld } & \text { sterk stijgend } \\ \text { gemiddeld } & - \\ \text { gemiddeld } & - \\ \text { laag } & - \\ \text { hoog } & \text { sterk stijgend } \\ \text { erg hoog } & \text { sterk stijgend } \\ \text { erg hoog } & \text { stijgend } \\ \text { gemiddeld } & -\end{array}$

erg hoog

constant

laag

gemiddeld

laag

laag

laag

gemiddeld

laag

laag

laag

laag

laag

laag

hoog

laag

gemiddeld

laag

gemiddeld

gemiddeld

erg hoog

hoog

gemiddeld

laag

$-$

sterk stijgend

sterk dalend

sterk stijgend

sterk stijgend

-

sterk stijgend

sterk stijgend sterk dalend stijgend

-

sterk dalend

sterk stijgend constant sterk stijgend

sterk stijgend sterk stijgend

gemiddeld

hoog

gemiddeld sterk stijgend 
Tabel 3.11 (vervolg)

Flexibel werk per opleidingstype, gemiddelde 1994-1995

\begin{tabular}{llll}
\hline Opleidingstype & $\%$ & typering & trend \\
$1993-' 95$
\end{tabular}

HBO

HBO onderwijs

HBO tolk en vertaler

HBO landbouw en milieukunde

HBO technisch laboratorium

HBO (weg- en water)bouwkunde

HBO werktuigbouwkunde

HBO elektrotechniek en technische informatica

HBO haven en vervoer

HBO medisch laboratorium

$H B O$ verpleging en paramedisch

$H B O$ bedrijfseconomie

HBO accountancy

HBO bedrijfsinformatica

HBO toerisme en recreatie

HBO commerciële economie

$\mathrm{HBO}$ technische bedrijfskunde

HBO bestuurlijk-juridisch

HBO sociaal-cultureel

HBO kunst

HBO politie en defensie

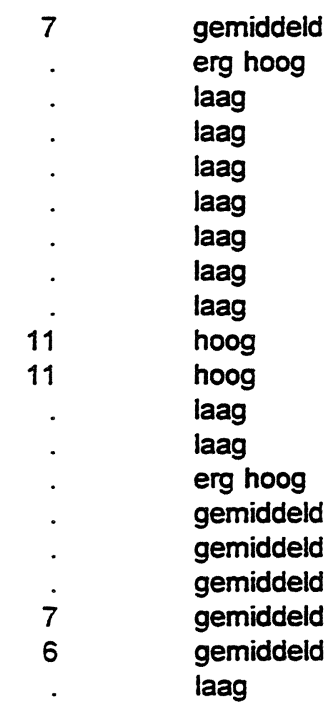

stijgend

sterk stijgend

sterk stijgend

sterk stijgend

sterk stijgend

sterk stijgend

sterk dalend

sterk stijgend

sterk stijgend

-

sterk stijgend

sterk stijgend

sterk stijgend

sterk stijgend

sterk stijgend

sterk stijgend

wo

WO letteren

WO theologisch

WO landbouw en milieukunde

WO wiskunde en natuunwetenschappen

WO (weg-en water)bouwkunde

WO werktuigbouwkunde

WO elektrotechniek en technische informatica

WO dier-, genees- en tandheelkunde

WO farmacie

WO econom(etr)ie en accountancy

WO bedrijfskunde

WO informatica

wO juridisch

WO bestuurlijk

Wo sociaal-cultureel

WO kunst

$\begin{array}{ll}\begin{array}{ll}\text { gemiddeld } \\ \text { gemiddeld }\end{array} & \begin{array}{l}\text { constant } \\ \text { sterk stijgend }\end{array} \\ \text { gemiddeld } & - \\ \text { laag } & \text { sterk stijgend } \\ \text { laag } & \text { sterk stijgend } \\ \text { gemiddeld } & \text { sterk stijgend } \\ \text { laag } & - \\ \text { laag } & \text { sterk stijgend } \\ \text { laag } & - \\ \text { laag } & \text { sterk dalend } \\ \text { laag } & - \\ \text { gemiddeld } & - \\ \text { laag } & - \\ \text { gemiddeld } & \text { sterk stijgend } \\ \text { gemiddeld } & \text { sterk stijgend } \\ \text { gemiddeld } & \text { sterk dalend }\end{array}$

Bron: CBS/ROA 
Tabel 3.12

Percentage werknemers met vast werk per opleidingstype, gemiddelde 1994-1995

\begin{tabular}{|c|c|c|c|}
\hline Opleidingstype & $\%$ & typering & $\begin{array}{l}\text { trend } \\
1993-' 95\end{array}$ \\
\hline
\end{tabular}

\section{BASISONDERWIJS}

Basisonderwijs

90

MAVO, VBO

MAVO, onderbouw HAVONWO

VBO landbouw en natuurlijke omgeving

VBO bouwtechniek

VBO installatietechniek

VBO mechanische techniek

VBO motorvoertuigentechniek

VBO elektrotechniek

VBO grafische techniek

VBO consumptieve techniek

VBO textiel- en ledertechniek

VBO haven en vervoer

VBO administratie

VBO verkoop en handel

VBO verzorging

VBO bewaking

\section{HAVONWO, MBORLW}

HAVONWO bovenbouw

MBO/LLW landbouw en natuurlijke omgeving

MBO technisch laboratorium

MBOLLW bouwkunde

MBO/LWW weg-en waterbouwkunde

MBO/LLW metaalkunde

MBO/LLW fijnmechanische techniek

MBO/LLW werktuigbouwkunde

MBO/LLW motorvoertuigentechniek

MBO/LLW elektrotechniek

MBO/LLW grafische techniek

MBO/LLW consumptieve techniek

MBO/LLW procestechniek

MBO/LLW textiel- en ledertechniek

MBO/LLW haven en vervoer

$M B O / L W$ verpleging en medische assistentie

MBO/LLW medisch laboratorium

MBO/LLW handel

$M B O / L W$ administratief

MBO toerisme en recreatie

MBO LLW commercieel

MBO/LLW secretarieel

MBO bestuurlijk-juridisch

MBO sociaal-cultureel

MBO/LLW verzorging

MBO/LLW horeca en uiterlijke verzorging

MBO politie en defensie laag

constant

\begin{tabular}{|c|c|}
\hline $\begin{array}{l}\text { erg laag } \\
\text { laag } \\
\text { gemiddeld } \\
\text { erg laag } \\
\text { gemiddeld } \\
\text { gemiddeld } \\
\text { gemiddeld } \\
\text { laag } \\
\text { laag } \\
\text { laag } \\
\text { gemiddeld } \\
\text { erg laag } \\
\text { erg laag } \\
\text { erg laag } \\
\text { gemiddeld }\end{array}$ & $\begin{array}{l}\text { constant } \\
\text { constant } \\
\text { dalend } \\
\text { constant } \\
\text { constant } \\
- \\
- \\
- \\
\text { stijgend } \\
- \\
\text { dalend } \\
\text { dalend } \\
\text { constant } \\
-\end{array}$ \\
\hline
\end{tabular}

$\begin{array}{ll}\text { erg laag } & - \\ \text { laag } & - \\ \text { erg laag } & - \\ \text { hoog } & - \\ \text { gemiddeld } & \text { constant } \\ \text { hoog } & \text { constant } \\ \text { laag } & \text { constant } \\ \text { gemiddeld } & \text { constant } \\ \text { hoog } & - \\ \text { gemiddeld } & - \\ \text { hoog } & - \\ \text { gemiddeld } & - \\ \text { hoog } & \text { constant } \\ \text { erg laag } & \text { dalend } \\ \text { gemiddeld } & \text { constant } \\ \text { laag } & - \\ \text { hoog } & \text { constant } \\ \text { laag } & - \\ \text { gemiddeld } & \text { constant } \\ \text { erg laag } & - \\ \text { erg laag } & \text { constant } \\ \text { laag } & \text { constant } \\ \text { erg hoog } & - \\ \text { laag } & - \\ \text { erg laag } & \text { constant } \\ \text { laag } & - \\ \text { erg hoog } & -\end{array}$


Tabel 3.12 (vervolg)

Percentage werknemers met vast werk per opleidingstype, gemiddelde 1994-1995

\begin{tabular}{llll}
\hline Opleidingstype & $\%$ & typering & $\begin{array}{c}\text { trend } \\
1993-95\end{array}$ \\
& & & \\
\hline
\end{tabular}

\section{HBO}

HBO onderwijs

$\mathrm{HBO}$ tolk en vertaler

HBO landbouw en milieukunde

HBO technisch laboratorium

HBO (weg- en water)bouwkunde

$\mathrm{HBO}$ werktuigbouwkunde

HBO elektrotechniek en technische informatica

$\mathrm{HBO}$ haven en vervoer

HBO medisch laboratorium

$\mathrm{HBO}$ verpleging en paramedisch

$\mathrm{HBO}$ bedrijfseconomie

$\mathrm{HBO}$ accountancy

HBO bedrijfsinformatica

HBO toerisme en recreatie

HBO commerciële economie

HBO technische bedrijfskunde

$\mathrm{HBO}$ bestuurlijk-juridisch

HBO sociaal-cultureel

HBO kunst

HBO politie en defensie

wo

WO letteren

WO theologisch

WO landbouw en milieukunde

WO wiskunde en natuurwetenschappen

WO (weg- en water)bouwkunde

WO werktuigbouwkunde

WO elektrotechniek en technische informatica

WO dier-, genees- en tandheelkunde

WO farmacie

WO econom(etr)ie en accountancy

WO bedrijfskunde

WO informatica

WO juridisch

WO bestuurlijk

WO sociaal-cultureel

WO kunst

$\begin{array}{ll}\text { gemiddeld } & \begin{array}{l}\text { constant } \\ \text { erg laag }\end{array} \\ \text { sterk dalend } \\ \text { dalend } \\ \text { gemiddeld } & - \\ \text { hoog } & - \\ \text { gemiddeld } & - \\ \text { gemiddeld } & \text { dalend } \\ \text { gemiddeld } & \text { constant } \\ \text { hoog } & - \\ \text { erg laag } & - \\ \text { erg laag } & \text { dalend } \\ \text { erg hoog } & - \\ \text { hoog } & \text { dalend } \\ \text { erg laag } & - \\ \text { gemiddeld } & \text { constant } \\ \text { gemiddeld } & - \\ \text { laag } & \text { constant } \\ \text { laag } & \text { constant } \\ \text { laag } & - \\ \text { erg hoog } & \text { constant }\end{array}$

$\begin{array}{ll}\text { erg laag } & - \\ \text { laag } & \text { dalend } \\ \text { hoog } & - \\ \text { hoog } & - \\ \text { gemiddeld } & - \\ \text { gemiddeld } & - \\ \text { laag } & - \\ \text { laag } & \text { constant } \\ \text { erg laag } & \text { stijgend } \\ \text { gemiddeld } & - \\ \text { laag } & \text { stijgend } \\ \text { erg hoog } & \text { dalend } \\ \text { gemiddeld } & - \\ \text { gemiddeld } & \text { dalend } \\ \text { gemiddeld } & \text { constant } \\ \text { erg laag } & \text { stijgend }\end{array}$

Bron: CBS/ROA 
Tabel 3.13

Percentage werkzame schoolverlaters met een vast dienstverband per opleidingsrichting, 1995

\begin{tabular}{lll}
\hline Opleidingstype en -richting & $\%$ & typering \\
\hline
\end{tabular}

MAVO, VBO

MAVO En onderbouW HAVOMWO

VBO land- en tuinbouw

VBO technisch

VBO bouwtechniek

VBO mechanische techniek

VBO motorvoertuigentechniek

VBO elektrotechniek

VBO grafische techniek

VBO consumptieve techniek

VBO textiel- en ledertechniek

VBO economisch-administratief

VBO administratie

VBO verkoop en handel

VBO verzorgend

VBO verzorging

VBO uiterlijke verzorging

HAVONWO, MBO

HAVONWO bOVENBOUW
HAVO

WNO

42

33

MBO landbouw en natuurijke omgeving

KMBO agrarisch

MBO plantenteelt

$M B O$ veehouderij

MBO levensmiddelentechnologie

MBO bloemschikken

MBO dierenverzorging

MBO groene ruimte

MBO technisch laboratorium

MBO chemisch laboratorium

MBO technisch

KMBO motorvoertuigentechniek

KMBO elektrotechniek

KMBO consumptieve techniek

MBO bouwkunde

MBO weg-en waterbouwkunde

MBO mechanische techniek

MBO werktuigbouwkunde

MBO motorvoertuigentechniek

MBO elektrotechniek

MBO textiel- en ledertechniek
54

41

41

50

71

42

29

.

37

72

67

gemiddeld

gemiddeld

erg laag

erg laag

gemiddeld

hoog

erg laag

erg hoog

erg laag

erg hoog

erg laag

erg hoog

hoog erg laag

erg laag

gemiddeld

erg hoog

gemiddeld

erg laag

erg hoog

erg hoog

gemiddeld

52

gemiddeld

hoog

gemiddeld

erg laag

hoog

erg hoog

gemiddeld

hoog

erg hoog

hoog

gemiddeld 
Tabel 3.13 (vervolg)

Percentage werkzame schoolverlaters met een vast dienstverband per opleidingsrichting, 1995

\begin{tabular}{|c|c|c|}
\hline Opleidingstype en -richting & $\%$ & typering \\
\hline MBO haven en vervoer & 73 & erg hoog \\
\hline \multicolumn{3}{|c|}{ MBO verpleging en medische assistentie } \\
\hline MBO verpl. en ziekenverzorging & 60 & gemiddeld \\
\hline MBO assistent gezondheidszorg & 74 & erg hoog \\
\hline \multicolumn{3}{|l|}{ MBO economisch-administratief } \\
\hline KMBO detailhandel & 58 & gemiddeld \\
\hline KMBO administratie & 49 & laag \\
\hline MBO handel & 71 & hoog \\
\hline MBO administratie & 62 & gemiddeld \\
\hline MBO toerisme & 62 & gemiddeld \\
\hline MBO commercieel & 61 & gemiddeld \\
\hline MBO secretarieel & 65 & hoog \\
\hline MBO bestuurlijk & $\cdot$ & gemiddeld \\
\hline MBO sociale arbeid & 45 & laag \\
\hline \multicolumn{3}{|l|}{ MBO verzorgend } \\
\hline KMBO verzorging & 62 & gemiddeld \\
\hline MBO agogisch werk & 59 & gemiddeld \\
\hline MBO verzorging & 69 & hoog \\
\hline MBO mode en kleding & 83 & erg hoog \\
\hline MBO activiteitenbegeleiding & 71 & hoog \\
\hline \multicolumn{3}{|l|}{ MBO horeca en uiterlijke verzorging } \\
\hline MBO horeca & 67 & hoog \\
\hline MBO facilitaire dienstverlening & 66 & hoog \\
\hline MBO uiterlijke verzorging & 76 & erg hoog \\
\hline \multicolumn{3}{|l|}{ HBO } \\
\hline \multicolumn{3}{|l|}{ HBO onderwijs } \\
\hline HBO basisonderwijzer & 48 & laag \\
\hline HBO leraar agrarisch & 42 & erg laag \\
\hline HBO leraar kunst/expressie & & laag \\
\hline HBO leraar voortgezet onderwijs & 54 & gemiddeld \\
\hline HBO tolk en vertaler & 59 & gemiddeld \\
\hline HBO agrarisch & 47 & laag \\
\hline HBO technisch laboratorium & 33 & erg laag \\
\hline \multicolumn{3}{|l|}{ HBO technisch } \\
\hline HBO (weg-en water)bouwkunde & 57 & gemiddeld \\
\hline HBO werktuigbouwkunde & 47 & laag \\
\hline HBO elektrotechiek & 57 & gemiddeld \\
\hline HBO haven en vervoer & 89 & erg hoog \\
\hline
\end{tabular}


Tabel 3.13 (vervolg)

Percentage werkzame schoolverlaters met een vast dienstverband per opleidingsrichting, 1995

\begin{tabular}{lll}
\hline Opleidingstype en -richting & $\%$ & typering \\
\hline HBO medisch analist & 48 & laag \\
HBO verpleging en paramedisch & & \\
HBO verpleegkunde & 67 & hoog \\
HBO (fysio-)therapie & 63 & gemiddeld \\
HBO economisch-administratief & & \\
HBO bedrijfseconomie & 55 & gemiddeld \\
HBO accountancy & 64 & $\begin{array}{l}\text { hoog } \\
\text { HBO bedrijfsinformatica }\end{array}$ \\
HBO toerisme & 66 & laag \\
HBO commerciële economie & 49 & gemiddeld \\
HBO technische bedrijfskunde & 60 & gemiddeld \\
HBO bestuurijkjuridisch & 56 & gemiddeld \\
HBO sociaal-cultureel & & \\
HBO welzijnswerk/sociaal & & gemiddeld \\
HBO personeelswerk & 56 & laag \\
HBO joumalistiek & 36 & erg laag \\
HBO kunst & 39 & gemiddeld \\
\hline
\end{tabular}

Bron: RUBS/HBO-Monitor/ROA 
Tabel 3.14

Gemiddeld bruto maandloon van werkzame schoolverlaters per opleidingsrichting, 1995

\begin{tabular}{lcc}
\hline Opleidingstype en -richting & $\begin{array}{c}\text { gemiddeld bruto } \\
\text { maandloon, } \\
\text { guidens }\end{array}$ & typering \\
\hline
\end{tabular}

MAVO, VBO

MAVO en onderbouW HAVONWO

VBO land-en tuinbouw

VBO technisch

VBO bouwtechniek

VBO mechanische techniek

VBO motorvoertuigentechniek

VBO elektrotechniek

VBO grafische techniek

VBO consumptieve techniek

VBO textiel- en ledertechniek

VBO economisch-administratief

VBO administratie

VBO verkoop en handel

VBO verzorgend

VBO verzorging

VBO uiterijke verzorging

HAVONWO, MBO

HAVONWO bovenbourW

HAVO

WWO

MBO landbouw en natuurlijke omgeving

KMBO agrarisch

MBO plantenteelt

$M B O$ veehouderij

MBO levensmiddelentechnologie

MBO bloemschikken

MBO dierenverzorging

MBO groene ruimte

MBO technisch laboratorium MBO chemisch laboratorium

MBO technisch

KMBO motorvoertuigentechniek

KMBO elektrotechniek

KMBO consumptieve techniek

MBO bouwkunde

MBO weg-en waterbouwkunde

MBO mechanische techniek

MBO werktuigbouwkunde

MBO motorvoertuigentechniek

MBO elektrotechniek
1.156

1.190

1.150

1.097

1.177

gemiddeld voor mavo/vbo

1.217

1.094

941

1.430

919

1.454

1.769

2.242

2.094

2.354

1.613

1.818

2.236

1.520

1.925

1.738

2.504

2.489

2.366

2.539

2.527

2.320 gemiddeld voor mavo/vbo

gemiddeld voor mavo/vbo gemiddeld voor mavo/vbo gemiddeld voor mavo/vbo laag voor mavo/vbo gemiddeld voor mavo/vbo hoog voor mavo/vbo laag voor mavo/vbo

gemiddeld voor mavo/vbo gemiddeld voor mavo/vbo

gemiddeld voor mavo/vbo laag voor mavo/vbo

laag voor havo/mwo/mbo laag voor havo/vwo/mbo

gemiddeld voor havo/nwo/mbo gemiddeld voor havo/nwo/mbo gemiddeld voor havo/uwo/mbo gemiddeld voor havo/nwo/mbo gemiddeld voor havo/wwo/mbo gemiddeld voor havo/wwo/mbo gemiddeld voor havo/uwo/mbo

hoog voor havo/wwo/mbo

laag voor havo/wwo/mbo gemiddeld voor havo/uwo/mbo gemiddeld voor havo/vwo/mbo hoog voor havo/wwo/mbo hoog voor havo/wwo/mbo gemiddeld voor havo/vwo/mbo hoog voor havo/wwo/mbo hoog voor havo/uwo/mbo gemiddeld voor havo/nwo/mbo 
Tabel 3.14 (vervolg)

Gemiddeld bruto maandloon van werkzame schoolverlaters per opleidingsrichting, 1995

\begin{tabular}{|c|c|c|}
\hline Opleidingstype en -richting & $\begin{array}{l}\text { gemiddeld bruto } \\
\text { maandloon, } \\
\text { guldens }\end{array}$ & typering \\
\hline MBO textiel- en ledertechniek & 1.669 & gemiddeld voor havo/vwo/mbo \\
\hline MBO haven en vervoer & 3.055 & erg hoog voor havo/nwo/mbo \\
\hline \multicolumn{3}{|c|}{ MBO verpleging en medische assistentie } \\
\hline MBO verpl. en ziekenverzorging & 2.292 & gemidideld voor havo/vwo/mbo \\
\hline MBO assistent gezondheidszorg & 2.189 & \\
\hline \multicolumn{3}{|l|}{ MBO economisch-administratief } \\
\hline KMBO detailhandel & 1.516 & laag voor havo/nwo/mbo \\
\hline KMBO administratie & 1.684 & gemiddeld voor havo/uwo/mbo \\
\hline MBO handel & 1.983 & gemiddeld voor havo/vwo/mbo \\
\hline MBO administratie & 1.930 & gemiddeld voor havo/uwo/mbo \\
\hline MBO toerisme & 2.220 & gemiddeld voor havo/vwo/mbo \\
\hline MBO commercieel & 1.901 & gemiddeld voor havo/vwo/mbo \\
\hline MBO secretarieel & 1.908 & gemiddeld voor havo/vwo/mbo \\
\hline MBO bestuurlijk & 1.656 & gemiddeld voor havo/uwo/mbo \\
\hline MBO sociale arbeid & 2.304 & gemiddeld voor havo/vwo/mbo \\
\hline \multicolumn{3}{|l|}{ MBO verzorgend } \\
\hline KMBO verzorging & 1.654 & gemiddeld voor havo/vwo/mbo \\
\hline MBO agogisch werk & 2.027 & gemiddeld voor havo/vwo/mbo \\
\hline MBO verzorging & 2.192 & gemiddeld voor havo/vwo/mbo \\
\hline MBO mode en kleding & 1.614 & gemiddeld voor havo/vwo/mbo \\
\hline MBO activiteitenbegeleiding & 2.635 & hoog voor havo/vwo/mbo \\
\hline \multicolumn{3}{|l|}{ MBO horeca en uiterlijke verzorging } \\
\hline MBO horeca & 2.734 & hoog voor havo/vwo/mbo \\
\hline MBO facilitaire dienstveriening & 1.953 & gemiddeld voor havo/vwo/mbo \\
\hline MBO uiterlijke verzorging & 2.024 & gemiddeld voor havo/uwo/mbo \\
\hline \multicolumn{3}{|l|}{ HBO } \\
\hline \multicolumn{3}{|l|}{ HBO onderwijs } \\
\hline HBO basisonderwijzer & 3.260 & gemiddeld voor hbo \\
\hline HBO leraar agrarisch & 3.150 & gemiddeld voor hbo \\
\hline HBO leraar kunst/expressie & 3.592 & gemiddeld voor hbo \\
\hline HBO leraar voortgezet onderwijs & 3.243 & gemiddeld voor hbo \\
\hline HBO tolk en vertaler & 3.111 & gemiddeld voor hbo \\
\hline HBO agrarisch & 3.073 & gemiddeld voor hbo \\
\hline HBO technisch laboratorium & 3.009 & gemiddeld voor hbo \\
\hline \multicolumn{3}{|l|}{ HBO technisch } \\
\hline HBO (weg- en water)bouwkunde & 3.300 & gemiddeld voor hbo \\
\hline HBO werktuigbouwkunde & 3.381 & gemiddeld voor hbo \\
\hline HBO elektrotechiek & 3.270 & gemiddeld voor hbo \\
\hline
\end{tabular}


Tabel 3.14 (vervolg)

Gemiddeld bruto maandloon van werkzame schoolverlaters per opleidingsrichting, 1995

\begin{tabular}{|c|c|c|}
\hline Opleidingstype en -richting & $\begin{array}{l}\text { gemiddeld bruto } \\
\text { maandloon, } \\
\text { guldens }\end{array}$ & typering \\
\hline HBO haven en vervoer & 2.901 & gemiddeld voor hbo \\
\hline HBO medisch analist & 3.042 & gemiddeld voor hbo \\
\hline $\begin{array}{l}\text { HBO verpleging en paramedisch } \\
\text { HBO verpleegkunde } \\
\text { HBO (fysio-)therapie }\end{array}$ & $\begin{array}{l}3.460 \\
3.967\end{array}$ & $\begin{array}{l}\text { gemiddeld voor hbo } \\
\text { hoog voor hbo }\end{array}$ \\
\hline $\begin{array}{l}\text { HBO economisch-administratief } \\
\text { HBO bedrijfseconomie } \\
\text { HBO accountancy } \\
\text { HBO bedrijfsinformatica } \\
\text { HBO toerisme } \\
\text { HBO commerciële economie }\end{array}$ & $\begin{array}{l}3.107 \\
3.162 \\
3.246 \\
2.859 \\
3.101\end{array}$ & $\begin{array}{l}\text { gemiddeld voor hbo } \\
\text { gemiddeld voor hbo } \\
\text { gemiddeld voor hbo } \\
\text { gemiddeld voor hbo } \\
\text { gemiddeld voor hbo }\end{array}$ \\
\hline HBO technische bedrijfskunde & 3.343 & gemiddeld voor hbo \\
\hline HBO bestuurlijkjuridisch & 2.812 & gemiddeld voor hbo \\
\hline $\begin{array}{l}\text { HBO sociaal-cultureel } \\
\text { HBO welzijnswerk/sociaal } \\
\text { HBO personeelswerk } \\
\text { HBO journalistiek }\end{array}$ & $\begin{array}{l}3.134 \\
3.338 \\
3.271\end{array}$ & $\begin{array}{l}\text { gemiddeld voor hbo } \\
\text { gemiddeld voor hbo } \\
\text { gemiddeld voor hbo }\end{array}$ \\
\hline HBO kunst & 3.151 & gemiddeld voor hbo \\
\hline
\end{tabular}

Bron: RUBS/HBO-Monitor/ROA 
Tabel 3.15

Belangrijkste beroepsklassen per opleidingstype, gemiddelde 1994-1995

\begin{tabular}{lll}
\hline Opleidingstype & $\%$ & trend \\
& & $1993-95$
\end{tabular}

\section{BASISONDERWIS}

\section{Basisonderwijs}

Portiers en schoonmaakpersoneel

Chauffeurs en spoorwegpersoneel

Expeditie-medewerkers

Verkooppersoneel

Keuken- en serveerpersoneel

Uitvoerend agrarisch personeel

Wegenbouwvakkrachten en buizenleggers

Commercieel-administratieve employés

Andere beroepsklassen"

\section{MAVO, VBO}

MAVO, onderbouW HAVONWO

Administrateurs en bankemployés

Commercieel-administratieve employés

Verkooppersoneel

Expeditie-medewerkers

Keuken- en serveerpersoneel

Portiers en schoonmaakpersoneel

Secretaresses en typisten

Chauffeurs en spoorwegpersoneel

Winkeliers en handelaars

Andere beroepsklassen

dalend

constant

stijgend

stijgend

sterk dalend

sterk stijgend

VBO landbouw en natuurlijke orngeving

Bedrijfsleiders in de landbouw

Uitvoerend agrarisch personeel

Chauffeurs en spoonwegpersoneel

Wegenbouwvakkrachten en buizenleggers

Expeditie-medewerkers

Verkooppersoneel

Andere beroepsklassen

VBO bouwtechniek

Timmerlieden

Metselaars en stukadoors

Schilders

Chauffeurs en spoonwegpersoneel

Ondernemers, uitvoerders en bedriffskundigen

Expeditie-medewerkers

Wegenbouwvakkrachten en buizenleggers

Andere beroepsklassen

constant

sterk stijgend

sterk stijgend

VBO installatietechniek

Loodgieters en installateurs

Andere beroepsklassen

VBO mechanische techniek

Lassers, constructeurs en edelsmeden

sterk dalend

dalend

sterk stijgend

constant

sterk stijgend

sterk dalend

sterk dalend

dalend 
Tabel 3.15 (vervolg)

Belangrijkste beroepsklassen per opleidingstype, gemiddelde 1994-1995

\begin{tabular}{|c|c|c|}
\hline Opleidingstype & $\%$ & $\begin{array}{l}\text { trend } \\
1993-95\end{array}$ \\
\hline Machinebank-, plaatwerkers en smeden & 9 & - \\
\hline Chauffeurs en spoorwegpersoneel & 8 & stijgend \\
\hline Ondernemers, uitvoerders en bedrijfskundigen & 6 & constant \\
\hline Instrumentmakers en onderhoudsmonteurs & 5 & sterk dalend \\
\hline Loodgieters en installateurs & 4 & - \\
\hline Metaalbewerkers & 4 & - \\
\hline Wegenbouwvakkrachten en buizenleggers & 4 & sterk stijgend \\
\hline Expeditie-medewerkers & 3 & - \\
\hline Andere beroepsklassen & 43 & - \\
\hline \multicolumn{3}{|l|}{ VBO motonvertuigentechniek } \\
\hline Automonteurs en -herstellers & 19 & sterk dalend \\
\hline Chauffeurs en spoorwegpersoneel & 15 & dalend \\
\hline Andere beroepsklassen & 66 & - \\
\hline \multicolumn{3}{|l|}{ VBO elektrotechniek } \\
\hline Monteurs en controleurs elektrotechnische installaties & 26 & - \\
\hline Chauffeurs en spoorwegpersoneel & 7 & sterk stijgend \\
\hline Ondememers, uitvoerders en bedrijfskundigen & 5 & sterk stijgend \\
\hline Instrumentmakers en onderhoudsmonteurs & 4 & - \\
\hline Andere beroepsklassen & 58 & - \\
\hline \multicolumn{3}{|l|}{ VBO grafische techniek } \\
\hline Productiepersoneel grafische industrie & 44 & - \\
\hline Andere beroepsklassen & 56 & - \\
\hline \multicolumn{3}{|l|}{ VBO consumptieve techniek } \\
\hline Bakkers en chocolademakers & 16 & - \\
\hline Keuken- en serveerpersoneel & 14 & - \\
\hline Andere beroepsklassen & 70 & - \\
\hline \multicolumn{3}{|l|}{ VBO textiel- en ledertechniek } \\
\hline Verkooppersoneel & 13 & sterk dalend \\
\hline Portiers en schoonmaakpersoneel & 11 & stijgend \\
\hline Andere beroepsklassen & 77 & - \\
\hline \multicolumn{3}{|l|}{ VBO haven en vervoer } \\
\hline Chauffeurs en spoonwegpersoneel & 61 & stijgend \\
\hline Andere beroepsklassen & 39 & - \\
\hline \multicolumn{3}{|l|}{ VBO administratie } \\
\hline Administrateurs en bankemployés & 20 & sterk dalend \\
\hline Commercieel-administratieve employés & 15 & - \\
\hline Verkooppersoneel & 10 & dalend \\
\hline Andere beroepsklassen & 56 & - \\
\hline \multicolumn{3}{|l|}{ VBO verkoop en handel } \\
\hline Verkooppersoneel & 22 & - \\
\hline Administrateurs en bankemployés & 8 & dalend \\
\hline Andere beroepsklassen & 69 & - \\
\hline
\end{tabular}


Tabel 3.15 (vervolg)

Belangrijkste beroepsklassen per opleidingstype, gemiddelde 1994-1995

\begin{tabular}{lll}
\hline Opleidingstype & $\%$ & trend
\end{tabular}

\section{VBO verzorging}

Verkooppersoneel

Portiers en schoonmaakpersoneel

Keuken- en serveerpersoneel

Kinder-, gezins- en bejaardenverzorgenden

Administrateurs en bankemployés

Uitvoerend agrarisch personeel

Expeditie-medewerkers

Commercieel-administratieve employés

Andere beroepsklassen

14

11

7

7

4

4

4

35

VBO bewaking

Politie en beveiligingspersonee!

Andere beroepsklassen

\section{HAVONWO, MBOILLW}

\section{HAVONWO bovenbouw}

Commercieel-administratieve employés

Administrateurs en bankemployés

Verkooppersoneel

Secretaresses en typisten

Programmeurs en systeemanalisten

Keuken- en serveerpersoneel

Ondernemers, uitvoerders en bedrijfskundigen

Filiaalhouders, inkopers en vertegenwoordigers

Winkeliers en handelaars

Andere beroepsklassen

MBO/LLW landbouw en natuurlijke omgeving

Bedrijfsleiders in de landbouw

Uitvoerend agrarisch personeel

Verkooppersoneel

Winkeliers en handelaars

Chauffeurs en spoorwegpersoneel

Andere beroepsklassen

12

12

7

6

4

4

3

43

MBO technisch laboratorium

Chemo-technici en laboranten

Andere beroepsklassen

\section{MBO/LLW bouwkunde}

Timmerlieden

Ondememers, uitvoerders en bedrijfskundigen

\section{Schilders}

Loodgieters en installateurs

Bouwkundige projectieiders

Metselaars en stukadoors

Technisch tekenaars

Andere beroepsklassen constant

dalend

stijgend

dalend

-

$-$

$-$

dalend

dalend

sterk stijgend

stijgend

stijgend

sterk stijgend

-

-

sterk dalend

stijgend

sterk dalend

dalend

dalend 
Tabel 3.15 (vervolg)

Belangrijkste beroepsklassen per opleidingstype, gemiddelde 1994-1995

\begin{tabular}{lll}
\hline Opleidingstype & $\%$ & trend \\
\hline
\end{tabular}

MBO/LW weg- en waterbouwkunde

1993-'95

Ondernemers, uitvoerders en bedrijfskundigen

Bouwkundige projectleiders

Technisch tekenaars

Andere beroepsklassen

MBORLW metaalkunde

Lassers, constructeurs en edelsmeden

Machinebank-, plaatwerkers en smeden

Instrumentmakers en onderhoudsmonteurs

Ondernemers, uitvoerders en bedrijfskundigen

Metaalbewerkers

Andere beroepsklassen

17

15

11

57

21

17

9

MBO/LLW fijnmechanische techniek

Diverse beroepsklassen

MBO/LW werktuigbouwkunde

Ondernemers, uitvoerders en bedrijfskundigen

Instrumentmakers en onderhoudsmonteurs

Machinebank-, plaatwerkers en smeden

Machinisten bouw en industrie

Technisch tekenaars

Lassers, constructeurs en edelsmeden

Commercieel-administratieve employés

Chauffeurs en spoorwegpersonee

Andere beroepsklassen

MBO/LW motorvoertuigentechniek

Automonteurs en -herstellers

Ondernemers, uitvoerders en bedrijfskundigen

Chauffeurs en spoorwegpersoneel

Machinebank-, plaatwerkers en smeden

Instrumentmakers en onderhoudsmonteurs

Winkeliers en handelaars

Andere beroepsklassen

MBO/LW elektrotechniek

Monteurs en controleurs elektrotechnische installaties

Ondernemers, uitvoerders en bedrijfskundigen

Instrumentmakers en onderhoudsmonteurs

Programmeurs en systeemanalisten

Machinebank-, plaatwerkers en smeden

Andere beroepsklassen

MBO/LW grafische techniek

Productiepersoneel grafische industrie

Ondememers, uitvoerders en bedrijfskundigen

Fotografen, ontwerpers en vormgevers

Andere beroepsklassen

\section{$-$}

sterk dalend

stijgend

sterk dalend

dalend

-

constant

stijgend

sterk dalend

stijgend

sterk stijgend

stijgend

dalend

sterk dalend

dalend

sterk stijgend

sterk dalend

stijgend 
Tabel 3.15 (vervolg)

Belangrijkste beroepsklassen per opleidingstype, gemiddelde 1994-1995

\begin{tabular}{lll}
\hline Opleidingstype & $\%$ & trend \\
& & $1993-95$
\end{tabular}

MBO/LW consumptieve techniek

Bakkers en chocolademakers

\section{4}

Voedings- en genotmiddelenbereiders

Winkeliers en handelaars

Ondernemers, uitvoerders en bedrijfskundigen

Filiaalhouders, inkopers en vertegenwoordigers

Andere beroepsklassen

MBO/LLW procestechniek

Productiepersoneel chemische industrie

Ondernemers, uitvoerders en bedrijfskundigen

Andere beroepsklassen

MBO/LLW textiel- en ledertechniek

Verkooppersoneel

Stoffeerders en lederwarenmakers

Patroonmakers, naaiers en zeilmakers

Andere beroepsklassen

MBO/LLW haven en vervoer

Chauffeurs en spoorwegpersoneel

Ondernemers, uitvoerders en bedrijfskundigen

Commercieel-administratieve employés

Schippers, officieren en loodsen

Administrateurs en bankemployés

Expeditie-medewerkers

Andere beroepsklassen

MBO/LLW verpleging en medische assistentie

Verpleegkundigen

Leerling-verpleegkundigen, zieken- en kraamverzorgenden

Dokters-, tandarts- en dierenartsassistenten

Kinder-, gezins- en bejaardenverzorgenden

Maatschappelijk werkers

Andere beroepsklassen

MBOLLW medisch laboratorium

Opticiens en apothekersassistenten

Analisten en laboranten

Andere beroepsklassen

MBO $L L W$ handel

Winkeliers en handelaars $\quad 17$

Verkooppersoneel

Commercieel-administratieve employés

Administrateurs en bankemployés

Filiaalhouders, inkopers en vertegenwoordigers

Ondernemers, uitvoerders en bedrijfskundigen

Secretaresses en typisten

Andere beroepsklassen

\section{dalend}

stijgend

dalend

sterk dalend

stijgend

sterk stijgend

sterk dalend

-

sterk dalend

sterk dalend

sterk stijgend

stijgend

-

sterk stijgend

stijgend

-

-

stijgend

constant

dalend

dalend

constant

const 
Tabel 3.15 (vervolg)

Belangrijkste beroepsklassen per opleidingstype, gemiddelde 1994-1995

\begin{tabular}{lll}
\hline Opleidingstype & $\%$ & trend
\end{tabular}

1993-'95

MBO/LWW administratief

Administrateurs en bankemployés

Commercieel-administratieve employés

constant

Hogere leidinggevenden financiën, verkoop e.d.

Ondernemers, uitvoerders en bedrijfskundigen

Economen en accountants

Andere beroepsklassen

MBO toerisme en recreatie

Receptionisten, telefonisten en enquêteurs

Administrateurs en bankemployés

Andere beroepsklassen

MBO LLW commercieel

Filiaalhouders, inkopers en vertegenwoordigers

Commercieel-administratieve employés

Administrateurs en bankemployés

Verkooppersoneel

Andere beroepsklassen

\section{2}

18

MBO/LLW secretarieel

Secretaresses en typisten

Commercieel-administratieve employés

Administrateurs en bankemployés

Receptionisten, telefonisten en enquêteurs

Verkooppersoneel

Andere beroepsklassen

MBO bestuurlijk-juridisch

Administrateurs en bankemployés

Commercieel-administratieve employés

Andere beroepsklassen

MBO sociaal-cultureel

Leerting-verpleegkundigen, zieken- en kraamverzorgenden

Maatschappelijk werkers

Kinder-, gezins- en bejaardenverzorgenden

Commercieel-administratieve employés

Bibliotheek- en archiefmedewerkers

Arbeidsconsulenten en personeelsdeskundigen

Andere beroepsklassen

\section{MBO/LW verzorging}

Kinder-, gezins- en bejaardenverzorgenden

Keuken- en serveerpersoneel

Leerling-verpleegkundigen, zieken- en kraamverzorgenden

Kappers en schoonheidsspecialisten

Verkooppersoneel

Commercieel-administratieve employés

Administrateurs en bankemployés

Portiers en schoonmaakpersoneel

Leidinggevenden horeca stijgend

sterk dalend

sterk stijgend

sterk dalend

stijgend

dalend

dalend

dalend

stijgend

-

$-$

$-$

dalend

sterk dalend

stijgend

sterk dalend

constant

dalend

- 
Tabel 3.15 (vervolg)

Belangrijkste beroepsklassen per opleidingstype, gemiddeide 1994-1995

\begin{tabular}{lll}
\hline Opleidingstype & $\%$ & trend \\
& & $1993-95$
\end{tabular}

Andere beroepsklassen

MBO/LW horeca en uiterlijke verzorging

Leidinggevenden horeca

Kappers en schoonheidsspecialisten

Keuken- en serveerpersonee!

Verkooppersoneel

Andere beroepsklassen

MBO politie en defensie

Politie en beveiligingspersoneel

Beroepsmilitairen

Chauffeurs en spoorwegpersoneel

Ondernemers, uitvoerders en bedrijfskundigen

Commercieel-administratieve employés

Andere beroepsklassen

23

17

16

40

38

15

5

4

35

HBO

\section{HBO onderwijs}

Leerkrachten basis- en speciaal ondenwijs

Docenten voortgezet onderwijs

Onderwijskundigen

Andere beroepsklassen

HBO tolk en vertaler

Diverse beroepsklassen

HBO landbouw en milieukunde

Bedriffsleiders in de landbouw

Andere beroepsklassen

HBO technisch laboratorium

Chemo-technici en laboranten

Analisten en laboranten

Natuurkundigen, technologen en statistici

Andere beroepsklassen

HBO (weg-en water)bouwkunde

Architecten en bouwkundige ingenieurs

Ondernemers, uitvoerders en bedrijfskundigen

Bouwkundige projectleiders

Technisch tekenaars

Andere beroepsklassen

HBO werktuigbouwkunde

Ondernemers, uitvoerders en bedrijfskundigen

Hogere werktuigkundigen

Andere beroepsklassen

62 stijgend

sterk dalend

sterk dalend

sterk dalend

sterk stijgend

sterk stijgend

-

constant

stijgend

sterk dalend

sterk dalend

sterk dalend

-

-

stijgend 
Tabel 3.15 (vervolg)

Belangrijkste beroepsklassen per opleidingstype, gemiddelde 1994-1995

\begin{tabular}{lll}
\hline Opleidingstype & $\%$ & trend \\
& & $1993-' 95$
\end{tabular}

Elektrotechnische constructeurs en ingenieurs

Ondememers, uitvoerders en bedrijfskundigen

Monteurs en controleurs elektrotechnische installaties

Andere beroepsklassen

HBO haven en vervoer

Vliegers, verkeersleiders en expediteurs

Ondernemers, uitvoerders en bedrijfskundigen

Schippers, officieren en loodsen

Andere beroepsklassen

HBO medisch laboratorium

Analisten en laboranten

Andere beroepsklassen

HBO verpleging en paramedisch

Verpleegkundigen

Fysio, arbeids- e.a. bewegingstherapeuten

Paramedische en verwante functies

Leerling-verpleegkundigen, zieken- en kraamverzorgenden

Andere beroepsklassen

\section{HBO bedrijfseconomie}

Administrateurs en bankemployés

Ondernemers, uitvoerders en bedrijfskundigen

Andere beroepsklassen

32

HBO accountancy

Administrateurs en bankemployés

Economen en accountants

Hogere leidinggevenden financiën, verkoop e.d.

Ondernemers, uitvoerders en bedrijfskundigen

Andere beroepsklassen

HBO bedrijfsinformatica

Programmeurs en systeemanalisten

Andere beroepsklassen

HBO toerisme en recreatie

Receptionisten, telefonisten en enquêteurs

Andere beroepsklassen

HBO commerciële economie

Filiaalhouders, inkopers en vertegenwoordigers

Administrateurs en bankemployés

Commercieel-administratieve employés

Hogere leidinggevenden financiën, verkoop e.d.

Andere beroepsklassen

HBO technische bedrijfskunde

Ondernemers, uitvoerders en bedrijfskundigen

Andere beroepsklassen
12

12

7

36

17

15

12

57

59

41

28

13

4

24

29

11

60

sterk dalend

dalend

sterk stijgend

-

dalend

sterk stijgend

constant

-

stijgend

-

-

dalend

sterk dalend

-

sterk stijgend

sterk dalend

sterk dalend

-

sterk dalend

64 stijgend

-

sterk stijgend

-

sterk dalend 
Tabel 3.15 (vervolg)

Belangrijkste beroepsklassen per opleidingstype, gemiddelde 1994-1995

\begin{tabular}{|c|c|c|}
\hline Opleidingstype & $\%$ & $\begin{array}{l}\text { trend } \\
1993-95\end{array}$ \\
\hline \multicolumn{3}{|l|}{ HBO bestuurlijk-juridisch } \\
\hline Commercieel-administratieve employés & 19 & - \\
\hline Administrateurs en bankemployés & 11 & sterk stijgend \\
\hline Beleidsmedewerkers en hoofdambtenaren & 11 & sterk dalend \\
\hline Economen en accountants & 10 & stijgend \\
\hline Andere beroepsklassen & 49 & - \\
\hline \multicolumn{3}{|l|}{ HBO sociaal-cultureel } \\
\hline Maatschappelijk werkers & 23 & dalend \\
\hline Arbeidsconsulenten en personeelsdeskundigen & 9 & dalend \\
\hline Hogere leidinggevenden financiën, verkoop e.d. & 6 & stijgend \\
\hline Bibliothecarissen en archivarissen & 6 & dalend \\
\hline Ondememers, uitvoerders en bedrijfskundigen & 6 & sterk stijgend \\
\hline Commercieet-administratieve employés & 5 & - \\
\hline Leerting-verpleegkundigen, zieken- en kraamverzorgenden & 5 & dalend \\
\hline Kinder-, gezins- en bejaardenverzorgenden & 4 & - \\
\hline Joumalisten en presentatoren & 4 & - \\
\hline Andere beroepsklassen & 32 & - \\
\hline \multicolumn{3}{|l|}{ HBO kunst } \\
\hline Regisseurs en kunstenaars & 34 & dalend \\
\hline Fotografen, ontwerpers en vormgevers & 20 & stijgend \\
\hline Docenten voortgezet onderwijs & 7 & - \\
\hline Andere beroepsklassen & 39 & $\cdot$ \\
\hline \multicolumn{3}{|l|}{ HBO politie en defensie } \\
\hline Beroepsmilitairen & 36 & - \\
\hline Andere beroepsklassen & 64 & - \\
\hline \multicolumn{3}{|l|}{ wo } \\
\hline \multicolumn{3}{|l|}{ wo letteren } \\
\hline Docenten voortgezet onderwijs & 34 & constant \\
\hline Joumalisten en presentatoren & 10 & - \\
\hline Taalkundigen, tolken en vertalers & 6 & - \\
\hline Andere beroepsklassen & 50 & - \\
\hline \multicolumn{3}{|l|}{ wO theologisch } \\
\hline Geestelijke verzorgers & 62 & - \\
\hline Andere beroepsklassen & 38 & - \\
\hline \multicolumn{3}{|l|}{ WO landbouw en milieukunde } \\
\hline Diverse beroepsklassen & 100 & - \\
\hline \multicolumn{3}{|l|}{ WO wiskunde en natuurwetenschappen } \\
\hline Docenten voortgezet onderwijs & 26 & - \\
\hline Natuurkundigen, technologen en statistici & 23 & dalend \\
\hline Programmeurs en systeemanalisten & 9 & - \\
\hline Ondernemers, uitvoerders en bedrijfskundigen & 7 & - \\
\hline Hogere leidinggevenden financiën, verkoop e.d. & 6 & - \\
\hline Andere beroepsklassen & 29 & - \\
\hline
\end{tabular}


Tabel 3.15 (vervolg)

Belangrijkste beroepsklassen per opleidingstype, gemiddelde 1994-1995

\begin{tabular}{lll}
\hline Opleidingstype & $\%$ & trend \\
$1993-95$
\end{tabular}

wo (weg-en water)bouwkunde

Architecten en bouwkundige ingenieurs

Andere beroepsklassen

WO werktuigbourwkunde

Ondememers, uitvoerders en bedrijfskundigen

Andere beroepsklassen

WO elektrotechniek en technische informatica

Programmeurs en systeemanalisten

Andere beroepsklassen

WO dier-, genees- en tandheelkunde

Artsen, medische specialisten en apothekers

Tandheelkundigen

Dierenartsen en diergeneeskundigen

Andere beroepsklassen

WO farmacie

Diverse beroepsklassen

WO econom(etr)ie en accountancy

Economen en accountants

Ondernemers, uitvoerders en bedrijfskundigen

Administrateurs en bankemployés

Hogere leidinggevenden financiën, verkoop e.d.

Docenten voortgezet onderwijs

Andere beroepsklassen

WO bedrijfskunde

Ondernemers, uitvoerders en bedrijfskundigen

Andere beroepsklassen

WO informatica

Diverse beroepsklassen

WO juridisch

Advocaten, rechters en notarissen

Commercieel-administratieve employés

Ondernemers, uitvoerders en bedrijfskundigen

Beleidsmedewerkers en hoofdambtenaren

Andere beroepsklassen

WO bestuurlijk

Economen en accountants

Andere beroepskiassen

Wo sociaal-cultureel

Sociale wetenschappers

Docenten voortgezet onderwijs

Maatschappelijk werkers

Onderwijskundigen
42

58

28

72

24

76

61

10

6

23

100

sterk dalend

sterk stijgend

dalend

-

dalend

dalend

-

sterk dalend

sterk stijgend sterk dalend

sterk dalend

32

sterk dalend

sterk dalend

sterk stiigend 
Tabel 3.15 (vervolg)

Belangrijkste beroepsklassen per opleidingstype, gemiddelde 1994-1995

\begin{tabular}{|c|c|c|}
\hline Opleidingstype & $\%$ & $\begin{array}{l}\text { trend } \\
1993-95\end{array}$ \\
\hline $\begin{array}{l}\text { Ondernemers, uitvoerders en bedrijfskundigen } \\
\text { Commercieel-administratieve employés } \\
\text { Hogere leidinggevenden financiën, verkoop e.d. } \\
\text { Andere beroepsklassen }\end{array}$ & $\begin{array}{r}9 \\
8 \\
4 \\
35\end{array}$ & $\begin{array}{l}\text { sterk dalend } \\
\text { sterk stijgend } \\
\text { sterk stijgend } \\
\text { - }\end{array}$ \\
\hline $\begin{array}{l}\text { WO kunst } \\
\text { Docenten voortgezet onderwijs } \\
\text { Andere beroepsklassen }\end{array}$ & $\begin{array}{l}35 \\
65\end{array}$ & $\begin{array}{l}\text { sterk dalend } \\
\text { - }\end{array}$ \\
\hline
\end{tabular}

\section{Bron: CBS/ROA}

- Een uitgebreidere versie van deze tabel is opgenomen in een aparte uitgave die bij het ROA verkregen kan worden: Verdeeltabellen van bedrijfssectoren, beroepsklassen en opleidingstypen.

- Deze beroepsklassen hebben elk een werkgelegenheidsaandeel van minder dan $3 \%$.

- Deze beroepsklassen hebben elk minder dan 2.500 werkenden. 
Tabel 3.16

Uitwijkmogelijkheden naar verschillende beroepsgroepen op een aansiuitend of hoger functieniveau per opleidingstype, gemiddelde 1994-1995

\begin{tabular}{ll}
\hline Opleidingstype & $\begin{array}{l}\text { Gini-Hirschman } \\
\text { spreidingsindex }\end{array}$
\end{tabular}

\section{BASISONDERWIS}

Basisonderwijs

MAVO, VBO

MAVO, onderbouw HAVONWO

VBO landbouw en natuurijke omgeving

VBO bouwtechniek

VBO installatietechniek

VBO mechanische techniek

VBO motorvoertuigentechniek

VBO elektrotechniek

VBO grafische techniek

VBO consumptieve techniek

VBO textiel- en ledertechniek

VBO haven en vervoer

VBO administratie

VBO verkoop en handel

VBO verzorging

VBO bewaking

HAVONWO, MBO/LLW

HAVONWO bovenbouW

MBO/LLW landbouw en natuurlijke omgeving

MBO technisch laboratorium

MBO/LLW bouwkunde

MBO/LLW weg- en waterbouwkunde

MBO/LLW metaalkunde

MBO/LLW fijnmechanische techniek

MBO/LLWW werktuigbouwkunde

MBO/LLW motorvoertuigentechniek

MBO/LW elektrotechniek

MBO/LLW grafische techniek

MBO/LLW consumptieve techniek

MBO/LLW procestechniek

MBO/LLW textiel- en ledertechniek

MBO/LLW haven en vervoer

MBO/LLW verpleging en medische assistentie

MBO/LLW medisch laboratorium

MBO/LLW handel

MBO/LLW administratief

MBO toerisme en recreatie

MBO/LLW commercieel

MBO/LLW secretarieel

MBO bestuurlijk-juridisch

MBO sociaal-cultureel

MBO/LLWW verzorging

MBO/LLW horeca en uiterlijke verzorging

MBO politie en defensie

$\begin{array}{ll}0,95 & \text { hoog } \\ 0,78 & \text { laag } \\ 0,87 & \text { gemiddeld } \\ 0,71 & \text { laag } \\ 0,97 & \text { erg hoog } \\ 0,86 & \text { gemiddeld } \\ 0,93 & \text { hoog } \\ 0,84 & \text { gemiddeld } \\ 0,85 & \text { gemiddeld } \\ 0,93 & \text { hoog } \\ 0,96 & \text { erg hoog } \\ 0,90 & \text { gemiddeld } \\ 0,96 & \text { erg hoog } \\ 0,93 & \text { hoog } \\ 0,92 & \text { hoog }\end{array}$

0,95

0,76

hoog

laag

laag

gemiddeld

gemiddeld

hoog

hoog

hoog

laag

hoog

hoog

gemiddeld

laag

hoog

hoog

laag

laag

erg hoog

laag

gemiddeld

hoog

laag

laag

gemiddeld

gemiddeld

gemiddeld

gemiddeld 
Tabel 3.16 (vervolg)

Uitwijkmogelijkheden naar verschillende beroepsgroepen op een aansluitend of hoger functieniveau per opleidingstype, gemiddelde 1994-1995

\begin{tabular}{ll}
\hline Opleidingstype & $\begin{array}{l}\text { Gini-Hirschman typering } \\
\text { spreidingsindex }\end{array}$ \\
\hline
\end{tabular}

HBO

$\mathrm{HBO}$ onderwijs

$0,79 \quad$ laag

HBO tolk en vertaler

HBO landbouw en milieukunde

HBO technisch laboratorium

HBO (weg-en water)bouwkunde

$\mathrm{HBO}$ werktuigbouwkunde

HBO elektrotechniek en technische informatica 0,88

HBO haven en vervoer

$\mathrm{HBO}$ medisch laboratorium

$\mathrm{HBO}$ verpleging en paramedisch

$\mathrm{HBO}$ bedrijfseconomie

HBO accountancy

HBO bedrijfsinformatica

HBO toerisme en recreatie

HBO commerciële economie

$\mathrm{HBO}$ technische bedrijfskunde

HBO bestuurlijk-juridisch

HBO sociaal-cultureel

HBO kunst

HBO politie en defensie

wo

Wo letteren

WO theologisch

WO landbouw en milieukunde

WO wiskunde en natuurwetenschappen

(weg- en water)bouwkunde

WO werktuigbouwkunde

WO dier-, genees- en tandheelkunde

WO farmacie

WO econom(etr)ie en accountancy

WO informatica

WO juridisch 
Tabel 3.17

Belangrijkste bedrijfssectoren per opleidingstype, gemiddelde $1994-1995^{\circ}$

\begin{tabular}{lll}
\hline Opleidingstype & $\%$ & trend \\
& & 1994 -'95 \\
\hline
\end{tabular}

\section{BASISONDERWJS}

\begin{tabular}{|c|c|c|}
\hline \multicolumn{3}{|l|}{ Basisonderwijs } \\
\hline Handel & 15 & constant \\
\hline Overige commerciële dienstverlening & 14 & stijgend \\
\hline Metaal en elektrotechniek & 14 & constant \\
\hline Bouw & 11 & dalend \\
\hline Transport, opslag en communicatie & 10 & sterk dalend \\
\hline Kwartaire diensten & 8 & constant \\
\hline Overige industrie & 6 & dalend \\
\hline Overheid & 5 & sterk stijgend \\
\hline Voedings- en genotmiddelenindustrie & 5 & stijgend \\
\hline Landbouw en visserij & 5 & stijgend \\
\hline Andere bedrijfssectoren & 7 & - \\
\hline \multicolumn{3}{|l|}{ MAVO, VBO } \\
\hline \multicolumn{3}{|l|}{ MAVO, onderbouw HAVOMWO } \\
\hline Handel & 22 & constant \\
\hline Overige commerciële dienstverlening & 14 & constant \\
\hline Kwartaire diensten & 91 & stijgend \\
\hline Overheid & 10 & dalend \\
\hline Transport, opslag en communicatie & 8 & constant \\
\hline Metaal en elektrotechniek & 8 & sterk stijgend \\
\hline Bank- en verzekeringswezen & 5 & constant \\
\hline Bouw & 5 & sterk stijgend \\
\hline Overige industrie & 4 & constant \\
\hline Landbouw en visserij & 3 & sterk dalend \\
\hline Voedings- en genotmiddelenindustrie & 3 & sterk dalend \\
\hline Andere bedrijfssectoren & 5 & - \\
\hline \multicolumn{3}{|l|}{ VBO landbouw en natuurlijke omgeving } \\
\hline Landbouw en visserij & 49 & constant \\
\hline Handel & 10 & dalend \\
\hline Overheid & 6 & constant \\
\hline Metaal en elektrotechniek & 6 & stijgend \\
\hline Bouw & 6 & sterk dalend \\
\hline Transport, opslag en communicatie & 6 & sterk dalend \\
\hline Overige commerciële dienstverlening & 5 & sterk stijgend \\
\hline Andere bedrijfssectoren & 11 & - \\
\hline \multicolumn{3}{|l|}{ VBO bouwtechniek } \\
\hline Bouw & 42 & constant \\
\hline Metaal en elektrotechniek & 12 & sterk stijgend \\
\hline Handel & 9 & constant \\
\hline Overige industrie & 7 & sterk dalend \\
\hline Transport, opslag en communicatie & 6 & sterk dalend \\
\hline Overheid & 6 & sterk stijgend \\
\hline Overige commerciële dienstverlening & 5 & sterk dalend \\
\hline Voedings- en genotmiddelenindustrie & 3 & sterk dalend \\
\hline Andere bedrijfssectoren & 9 & - \\
\hline
\end{tabular}


Tabel 3.17 (vervolg)

Belangrijkste bedrijfssectoren per opleidingstype, gemiddelde 1994-1995

\begin{tabular}{|c|c|c|}
\hline Opleidingstype & $\%$ & $\begin{array}{l}\text { trend } \\
1994-' 95\end{array}$ \\
\hline \multicolumn{3}{|l|}{ VBO installatietechniek } \\
\hline Bouw & 49 & stijgend \\
\hline Andere bedrijfssectoren & 51 & - \\
\hline \multicolumn{3}{|l|}{ VBO mechanische techniek } \\
\hline Metaal en elektrotechniek & 34 & stijgend \\
\hline Bouw & 14 & sterk dalend \\
\hline Transport, opslag en communicatie & 10 & sterk stijgend \\
\hline Handel & 9 & stijgend \\
\hline Overige commerciële dienstverlening & 8 & sterk dalend \\
\hline Overige industrie & 5 & sterk stijgend \\
\hline Overheid & 4 & constant \\
\hline Landbouw en visserij & 4 & sterk dalend \\
\hline Voedings- en genotmiddelenindustrie & 4 & sterk dalend \\
\hline Chemie & 4 & sterk stijgend \\
\hline Andere bedrijfssectoren & 5 & - \\
\hline \multicolumn{3}{|l|}{ VBO motorvoertuigentechniek } \\
\hline Overige commerciële dienstverlening & 26 & sterk dalend \\
\hline Transport, opslag en communicatie & 16 & sterk stijgend \\
\hline Handel & 14 & stijgend \\
\hline Metaal en elektrotechniek & 11 & sterk stijgend \\
\hline Bouw & 9 & sterk stijgend \\
\hline Overheid & 6 & sterk dalend \\
\hline Andere bedrijfssectoren & 18 & - \\
\hline \multicolumn{3}{|l|}{ VBO elektrotechniek } \\
\hline Bouw & 24 & sterk stijgend \\
\hline Metaal en elektrotechniek & 19 & constant \\
\hline Handel & 14 & sterk dalend \\
\hline Transport, opslag en communicatie & 11 & sterk stijgend \\
\hline Overige commerciële dienstverlening & 8 & dalend \\
\hline Overheid & 5 & sterk stijgend \\
\hline Overige industrie & 5 & sterk dalend \\
\hline Andere bedrijfssectoren & 14 & - \\
\hline \multicolumn{3}{|l|}{ VBO grafische techniek } \\
\hline Overige industrie & 49 & sterk stijgend \\
\hline Andere bedrijfssectoren & 51 & - \\
\hline \multicolumn{3}{|l|}{ VBO consumptieve techniek } \\
\hline Voedings- en genotmiddelenindustrie & 26 & sterk stijgend \\
\hline Handel & 20 & sterk stijgend \\
\hline Overige commerciële dienstverlening & 18 & dalend \\
\hline Andere bedrijfssectoren & 36 & - \\
\hline \multicolumn{3}{|l|}{ VBO textiel- en ledertechniek } \\
\hline Handel & 28 & dalend \\
\hline Kwartaire diensten & 18 & sterk stijgend \\
\hline Overige commerciële dienstverlening & 11 & sterk stijgend \\
\hline Andere bedrijfssectoren & 43 & - \\
\hline
\end{tabular}


Tabel 3.17 (vervolg)

Belangrijkste bedrijfssectoren per opleidingstype, gemiddelde 1994-1995

\begin{tabular}{|c|c|c|}
\hline Opleidingstype & $\%$ & $\begin{array}{l}\text { trend } \\
1994-95\end{array}$ \\
\hline \multicolumn{3}{|l|}{ VBO haven en vervoer } \\
\hline Transport, opslag en communicatie & 56 & dalend \\
\hline Handel & 13 & sterk stijgend \\
\hline Overige commerciële dienstverlening & 7 & constant \\
\hline Andere bedrijfssectoren & 24 & - \\
\hline \multicolumn{3}{|l|}{ VBO administratie } \\
\hline Handel & 22 & sterk stijgend \\
\hline Overige commerciële dienstverlening & 15 & sterk stijgend \\
\hline Overheid & 11 & stijgend \\
\hline Kwartaire diensten & 10 & stijgend \\
\hline Transport, opslag en communicatie & 9 & sterk dalend \\
\hline Metaal en elektrotechniek & 6 & sterk dalend \\
\hline Bank- en verzekeringswezen & 6 & sterk dalend \\
\hline Overige industrie & 4 & sterk dalend \\
\hline Landbouw en visserij & 4 & sterk dalend \\
\hline Bouw & 4 & sterk dalend \\
\hline Andere bedrijfssectoren & 8 & - \\
\hline \multicolumn{3}{|l|}{ VBO verkoop en handel } \\
\hline Handel & 41 & sterk stijgend \\
\hline Overige commerciële dienstverlening & 14 & sterk stijgend \\
\hline Andere bedrijfssectoren & 45 & - \\
\hline \multicolumn{3}{|l|}{ VBO verzorging } \\
\hline Handel & 23 & dalend \\
\hline Kwartaire diensten & 21 & stijgend \\
\hline Overige commerciële dienstverlening & 19 & stijgend \\
\hline Landbouw en visserij & 7 & sterk dalend \\
\hline Metaal en elektrotechniek & 5 & sterk dalend \\
\hline Overheid & 5 & sterk dalend \\
\hline Voedings- en genotmiddelenindustrie & 4 & constant \\
\hline Transport, opslag en communicatie & 4 & constant \\
\hline Overige industrie & 3 & stijgend \\
\hline Andere bedrijfssectoren & 8 & - \\
\hline \multicolumn{3}{|l|}{ VBO bewaking } \\
\hline Overige commerciële dienstveriening & 38 & sterk dalend \\
\hline Andere bedrijfssectoren & 62 & - \\
\hline \multicolumn{3}{|l|}{ HAVOMWO, MBOLLWW } \\
\hline \multicolumn{3}{|l|}{ HAVOMWO bovenbouw } \\
\hline Overige commerciële dienstverlening & 21 & dalend \\
\hline Handel & 18 & constant \\
\hline Overheid & 12 & constant \\
\hline Kwartaire diensten & 12 & dalend \\
\hline Bank- en verzekeringswezen & 10 & constant \\
\hline Transport, opslag en communicatie & 8 & sterk stijgend \\
\hline Metaal en elektrotechniek & 5 & sterk stijgend \\
\hline Overige industrie & 4 & dalend \\
\hline Andere bedrijfssectoren & 12 & - \\
\hline
\end{tabular}


Tabel 3.17 (vervolg)

Belangrijkste bedrijfssectoren per opleidingstype, gemiddelde 1994-1995

\begin{tabular}{|c|c|c|}
\hline Opleidingstype & $\%$ & $\begin{array}{l}\text { trend } \\
\text { 1994-'95 }\end{array}$ \\
\hline \multicolumn{3}{|c|}{ MBO/LW landbouw en natuurlijke omgeving } \\
\hline Landbouw en visserij & 56 & dalend \\
\hline Handel & 14 & dalend \\
\hline Overheid & 8 & constant \\
\hline Overige commerciële dienstverlening & 5 & sterk stijgend \\
\hline Metaal en elektrotechniek & 4 & stijgend \\
\hline Kwartaire diensten & 3 & sterk stijgend \\
\hline Andere bedrijfssectoren & 11 & - \\
\hline \multicolumn{3}{|l|}{ MBO technisch laboratorium } \\
\hline Kwartaire diensten & 17 & sterk stijgend \\
\hline Chemie & 17 & sterk stijgend \\
\hline Andere bedrijfssectoren & 65 & - \\
\hline \multicolumn{3}{|l|}{ MBO $L L W$ bouwkunde } \\
\hline Bouw & 59 & dalend \\
\hline Metaal en elektrotechniek & 9 & stijgend \\
\hline Handel & 6 & sterk dalend \\
\hline Overige commerciële dienstverlening & 6 & sterk stijgend \\
\hline Overheid & 6 & sterk stijgend \\
\hline Overige industrie & 4 & stijgend \\
\hline Andere bedrijfssectoren & 10 & - \\
\hline \multicolumn{3}{|l|}{ MBO $/ L W$ weg-en waterbouwkunde } \\
\hline Bouw & 35 & dalend \\
\hline Overheid & 33 & sterk dalend \\
\hline Overige commerciële dienstverlening & 11 & sterk stijgend \\
\hline Andere bedrijfssectoren & 22 & - \\
\hline \multicolumn{3}{|l|}{ MBO/LLW metaalkunde } \\
\hline Metaal en elektrotechniek & 56 & stijgend \\
\hline Bouw & 7 & stijgend \\
\hline Handel & 7 & sterk dalend \\
\hline Transport, opslag en communicatie & 6 & constant \\
\hline Overheid & 5 & stijgend \\
\hline Chemie & 4 & dalend \\
\hline Andere bedrijfssectoren & 15 & - \\
\hline \multicolumn{3}{|l|}{ MBO/LLW fijnmechanische techniek } \\
\hline Metaal en elektrotechniek & 29 & sterk dalend \\
\hline Handel & 25 & constant \\
\hline Andere bedrijfssectoren & 45 & - \\
\hline \multicolumn{3}{|l|}{ MBO/LLW werktuigbouwkunde } \\
\hline Metaal en elektrotechniek & 33 & constant \\
\hline Bouw & 11 & stijgend \\
\hline Handel & 11 & sterk stijgend \\
\hline Transport, opslag en communicatie & 9 & sterk dalend \\
\hline Overige commerciële dienstverlening & 9 & sterk dalend \\
\hline Energie & 6 & sterk stijgend \\
\hline Overheid & 5 & sterk stijgend \\
\hline Chemie & 4 & sterk dalend \\
\hline
\end{tabular}


Tabel 3.17 (vervolg)

Belangrijkste bedrijfssectoren per opleidingstype, gemiddelde 1994-1995

\begin{tabular}{|c|c|c|}
\hline Opleidingstype & $\%$ & $\begin{array}{l}\text { trend } \\
\text { 1994-'95 }\end{array}$ \\
\hline $\begin{array}{l}\text { Overige industrie } \\
\text { Voedings- en genotmiddelenindustrie } \\
\text { Andere bedrijfssectoren }\end{array}$ & $\begin{array}{l}4 \\
3 \\
6\end{array}$ & $\begin{array}{l}\text { sterk stijgend } \\
\text { sterk dalend } \\
\text { - }\end{array}$ \\
\hline $\begin{array}{l}\text { MBO/LLW motorvoertuigentechniek } \\
\text { Overige commerciële dienstverlening } \\
\text { Handel } \\
\text { Transport, opslag en communicatie } \\
\text { Metaal en elektrotechniek } \\
\text { Overheid } \\
\text { Bouw } \\
\text { Andere bedrijfssectoren }\end{array}$ & $\begin{array}{r}48 \\
14 \\
13 \\
8 \\
6 \\
4 \\
8\end{array}$ & $\begin{array}{l}\text { sterk stijgend } \\
\text { sterk dalend } \\
\text { dalend } \\
\text { sterk stijgend } \\
\text { sterk stijgend } \\
\text { sterk dalend } \\
\text { - }\end{array}$ \\
\hline $\begin{array}{l}\text { MBO/LW elektrotechniek } \\
\text { Bouw } \\
\text { Metaal en elektrotechniek } \\
\text { Handel } \\
\text { Transport, opslag en communicatie } \\
\text { Overige commerciële dienstverlening } \\
\text { Energie } \\
\text { Overheid } \\
\text { Chemie } \\
\text { Kwartaire diensten } \\
\text { Voedings- en genotmiddelenindustrie } \\
\text { Andere bedrijfssectoren }\end{array}$ & $\begin{array}{r}21 \\
17 \\
16 \\
9 \\
8 \\
6 \\
6 \\
4 \\
4 \\
3 \\
6\end{array}$ & $\begin{array}{l}\text { constant } \\
\text { constant } \\
\text { sterk stijgend } \\
\text { dalend } \\
\text { sterk dalend } \\
\text { sterk dalend } \\
\text { dalend } \\
\text { stijgend } \\
\text { stijgend } \\
\text { constant } \\
\text { - }\end{array}$ \\
\hline $\begin{array}{l}\text { MBO/LLW grafische techniek } \\
\text { Overige industrie } \\
\text { Overige commerciële dienstverlening } \\
\text { Handel } \\
\text { Andere bedrijfssectoren }\end{array}$ & $\begin{array}{r}56 \\
15 \\
7 \\
21\end{array}$ & $\begin{array}{l}\text { dalend } \\
\text { sterk stijgend } \\
\text { sterk dalend } \\
\text { - }\end{array}$ \\
\hline $\begin{array}{l}\text { MBO/LWW consumptieve techniek } \\
\text { Voedings- en genotmiddelenindustrie } \\
\text { Handel } \\
\text { Overige commerciële dienstverlening } \\
\text { Andere bedrijfssectoren }\end{array}$ & $\begin{array}{r}39 \\
38 \\
6 \\
17\end{array}$ & $\begin{array}{l}\text { dalend } \\
\text { stijgend } \\
\text { sterk dalend } \\
\text { - }\end{array}$ \\
\hline $\begin{array}{l}\text { MBO/LLW procestechniek } \\
\text { Chemie } \\
\text { Andere bedrijfssectoren }\end{array}$ & $\begin{array}{l}45 \\
55\end{array}$ & $\begin{array}{l}\text { constant } \\
\text { - }\end{array}$ \\
\hline $\begin{array}{l}\text { MBO/LLW textiel- en ledertechniek } \\
\text { Handel } \\
\text { Overige industrie } \\
\text { Overige commerciële dienstverlening } \\
\text { Kwartaire diensten } \\
\text { Andere bedrijfssectoren }\end{array}$ & $\begin{array}{r}39 \\
13 \\
13 \\
7 \\
27\end{array}$ & $\begin{array}{l}\text { sterk stijgend } \\
\text { sterk stijgend } \\
\text { sterk dalend } \\
\text { sterk dalend } \\
\text { - }\end{array}$ \\
\hline $\begin{array}{l}\text { MBO } L \perp W \text { haven en vervoer } \\
\text { Transport, opslag en communicatie } \\
\text { Handel }\end{array}$ & $\begin{array}{l}50 \\
10\end{array}$ & $\begin{array}{l}\text { dalend } \\
\text { sterk stijgend }\end{array}$ \\
\hline
\end{tabular}


Tabel 3.17 (vervolg)

Belangrijkste bedrijfssectoren per opleidingstype, gemiddelde 1994-1995

\begin{tabular}{|c|c|c|}
\hline Opleidingstype & $\%$ & $\begin{array}{l}\text { trend } \\
\text { 1994-'95 }\end{array}$ \\
\hline $\begin{array}{l}\text { Metaal en elektrotechniek } \\
\text { Overige commerciële dienstveriening } \\
\text { Overheid } \\
\text { Andere bedrijfssectoren }\end{array}$ & $\begin{array}{r}7 \\
6 \\
5 \\
22\end{array}$ & $\begin{array}{l}\text { constant } \\
\text { sterk dalend } \\
\text { sterk stijgend }\end{array}$ \\
\hline $\begin{array}{l}\text { MBO/LW verpleging en medische assist } \\
\text { Kwartaire diensten } \\
\text { Andere bedrijfssectoren }\end{array}$ & $\begin{array}{l}86 \\
14\end{array}$ & $\begin{array}{l}\text { constant } \\
\text { - }\end{array}$ \\
\hline $\begin{array}{l}\text { MBO/LW medisch laboratorium } \\
\text { Handel } \\
\text { Kwartaire diensten } \\
\text { Andere bedrijfssectoren }\end{array}$ & $\begin{array}{l}55 \\
26 \\
20\end{array}$ & $\begin{array}{l}\text { dalend } \\
\text { dalend } \\
-\end{array}$ \\
\hline $\begin{array}{l}\text { MBO/LLW handel } \\
\text { Handel } \\
\text { Overige commerciële dienstverlening } \\
\text { Overheid } \\
\text { Kwartaire diensten } \\
\text { Transport, opslag en communicatie } \\
\text { Metaal en elektrotechniek } \\
\text { Bouw } \\
\text { Bank- en verzekeringswezen } \\
\text { Overige industrie } \\
\text { Landbouw en visserij } \\
\text { Andere bedrijfssectoren }\end{array}$ & $\begin{array}{r}41 \\
12 \\
7 \\
6 \\
6 \\
5 \\
5 \\
5 \\
3 \\
3 \\
8\end{array}$ & $\begin{array}{l}\text { constant } \\
\text { stijgend } \\
\text { sterk dalend } \\
\text { stijgend } \\
\text { constant } \\
\text { stijgend } \\
\text { sterk dalend } \\
\text { constant } \\
\text { sterk stijgend } \\
\text { constant } \\
-\end{array}$ \\
\hline $\begin{array}{l}\text { MBO/LWW administratief } \\
\text { Overige commerciële dienstverlening } \\
\text { Handel } \\
\text { Overheid } \\
\text { Bank- en verzekeringswezen } \\
\text { Kwartaire diensten } \\
\text { Metaal en elektrotechniek } \\
\text { Bouw } \\
\text { Transport, opslag en communicatie } \\
\text { Overige industrie } \\
\text { Andere bedrijfssectoren }\end{array}$ & $\begin{array}{r}21 \\
15 \\
14 \\
10 \\
8 \\
8 \\
6 \\
6 \\
3 \\
9\end{array}$ & $\begin{array}{l}\text { stijgend } \\
\text { dalend } \\
\text { dalend } \\
\text { constant } \\
\text { constant } \\
\text { sterk stijgend } \\
\text { sterk stijgend } \\
\text { sterk dalend } \\
\text { sterk dalend } \\
\text { - }\end{array}$ \\
\hline $\begin{array}{l}\text { MBO toerisme en recreatie } \\
\text { Transport, opslag en communicatie } \\
\text { Andere bedrijfssectoren }\end{array}$ & $\begin{array}{l}43 \\
57\end{array}$ & $\begin{array}{l}\text { sterk stijgend } \\
\text { - }\end{array}$ \\
\hline $\begin{array}{l}\text { MBO/LLW commercieel } \\
\text { Handel } \\
\text { Bank- en verzekeringswezen } \\
\text { Overige commerciële dienstverlening } \\
\text { Bouw } \\
\text { Overheid } \\
\text { Andere bedrijfssectoren }\end{array}$ & $\begin{array}{r}26 \\
15 \\
14 \\
10 \\
7 \\
28\end{array}$ & $\begin{array}{l}\text { sterk stijgend } \\
\text { constant } \\
\text { sterk stijgend } \\
\text { dalend } \\
\text { sterk dalend } \\
\text { - }\end{array}$ \\
\hline
\end{tabular}


Tabel 3.17 (vervolg)

Belangrijkste bedrijfssectoren per opleidingstype, gemiddelde 1994-1995

\begin{tabular}{|c|c|c|}
\hline Opleidingstype & $\%$ & $\begin{array}{l}\text { trend } \\
\text { 1994-'95 }\end{array}$ \\
\hline \multicolumn{3}{|l|}{ MBO $L L W$ secretarieel } \\
\hline Kwartaire diensten & 22 & constant \\
\hline Overige commerciële dienstverlening & 19 & sterk stijgend \\
\hline Overheid & 15 & sterk stijgend \\
\hline Handel & 15 & dalend \\
\hline Bank- en verzekeringswezen & 5 & sterk dalend \\
\hline Bouw & 5 & stijgend \\
\hline Metaal en elektrotechniek & 5 & sterk dalend \\
\hline Transport, opslag en communicatie & 4 & sterk dalend \\
\hline Overige industrie & 3 & stijgend \\
\hline Andere bedrijfssectoren & 8 & - \\
\hline \multicolumn{3}{|l|}{ MBO bestuurlijk-juridisch } \\
\hline Overheid & 71 & constant \\
\hline Overige commerciële dienstverlening & 10 & sterk stijgend \\
\hline Andere bedrijfssectoren & 19 & - \\
\hline \multicolumn{3}{|l|}{ MBO sociaal-cultureel } \\
\hline Kwartaire diensten & 47 & stijgend \\
\hline Overheid & 26 & dalend \\
\hline Overige commerciële dienstverlening & 7 & sterk stijgend \\
\hline Handel & 4 & stijgend \\
\hline Andere bedrijfssectoren & 16 & - \\
\hline \multicolumn{3}{|l|}{ MBO/LLW verzorging } \\
\hline Kwartaire diensten & 48 & dalend \\
\hline Overige commerciële dienstverlening & 22 & constant \\
\hline Handel & 10 & stijgend \\
\hline Overheid & 5 & sterk stijgend \\
\hline Andere bedrijfssectoren & 15 & - \\
\hline \multicolumn{3}{|l|}{ MBO/LLW horeca en uiterlijke verzorging } \\
\hline Overige commerciële dienstverlening & 56 & sterk dalend \\
\hline Handel & 13 & sterk stijgend \\
\hline Kwartaire diensten & 11 & stijgend \\
\hline Overheid & 5 & sterk stijgend \\
\hline Transport, opslag en communicatie & 4 & dalend \\
\hline Andere bedrijfssectoren & 12 & - \\
\hline \multicolumn{3}{|l|}{ MBO politie en defensie } \\
\hline Overheid & 64 & constant \\
\hline Transport, opsiag en communicatie & 7 & dalend \\
\hline Overige commerciële dienstverlening & 6 & stijgend \\
\hline Metaal en elektrotechniek & 5 & sterk stijgend \\
\hline Handel & 4 & sterk stijgend \\
\hline Kwartaire diensten & 4 & sterk dalend \\
\hline Andere bedrijfssectoren & 11 & - \\
\hline \multicolumn{3}{|l|}{ HBO } \\
\hline HBO onderwijs & & constant \\
\hline Overheid & 75 & constant \\
\hline
\end{tabular}


Tabel 3.17 (vervolg)

Belangrijkste bedrijfssectoren per opleidingstype, gemiddelde 1994-1995

\begin{tabular}{lll}
\hline Opleidingstype & $\%$ & trend \\
& $1994-95$
\end{tabular}

Kwartaire diensten

Overige commerciële dienstveriening

Andere bedrijfssectoren

\section{HBO tolk en vertaler}

Overheid

Andere bedrijfssectoren

\section{HBO landbouw en milieukunde}

\section{Overheid}

Landbouw en visserij

Overige commerciële dienstveriening

Andere bedrijfssectoren

10

10
4

4
11

25

75

HBO technisch laboratorium

Overheid

Chemie

Kwartaire diensten

Overige commerciële dienstverlening

Andere bedrijfssectoren

HBO (weg-en water)bouwkunde

Overige commerciële dienstverlening

Bouw

Overheid

Andere bedrijfssectoren

HBO werktuigbouwkunde

Metaal en elektrotechniek

Overige commerciële dienstverlening

Handel

Overheid

Andere bedrijfssectoren

HBO elektrotechniek en technische informatica Overige commerciële dienstverlening Metaal en elektrotechniek

Handel

Overheid

Transport, opslag en communicatie

Bouw

Andere bedrijfssectoren

HBO haven en vervoer

Transport, opslag en communicatie

Handel

Energie

Overige commerciële dienstverlening

Overheid

Andere bedrijfssectoren constant

sterk stijgend

-

sterk dalend

sterk stijgend

sterk dalend

sterk stijgend

sterk dalend

stijgend

dalend

sterk stijgend

-

sterk dalend

constant

sterk stijgend

sterk stijgend

dalend

sterk stijgend

sterk dalend

stijgend

constant

sterk stijgend

sterk dalend

sterk dalend

sterk stijgend

-

sterk stijgend

dalend

stijgend

constant

sterk dalend 
Tabel 3.17 (vervolg)

Belangrijkste bedrijfssectoren per opleidingstype, gemiddelde 1994-1995

\begin{tabular}{|c|c|c|}
\hline Opleidingstype & $\%$ & $\begin{array}{l}\text { trend } \\
\text { 1994-'95 }\end{array}$ \\
\hline \multicolumn{3}{|l|}{ HBO medisch laboratorium } \\
\hline Kwartaire diensten & 75 & constant \\
\hline Andere bedrijfssectoren & 25 & - \\
\hline \multicolumn{3}{|l|}{ HBO verpleging en paramedisch } \\
\hline Kwartaire diensten & 86 & constant \\
\hline Overheid & 6 & sterk stijgend \\
\hline Andere bedrijfssectoren & 8 & - \\
\hline \multicolumn{3}{|l|}{ HBO bednijfseconomie } \\
\hline Overige commerciële dienstverlening & 31 & constant \\
\hline Overheid & 13 & sterk stijgend \\
\hline Handel & 13 & dalend \\
\hline Andere bedrijfssectoren & 43 & - \\
\hline \multicolumn{3}{|l|}{ HBO accountancy } \\
\hline Overige commerciële dienstverlening & 42 & sterk stijgend \\
\hline Overheid & 11 & sterk dalend \\
\hline Handel & 10 & sterk stijgend \\
\hline Bank- en verzekeringswezen & 9 & sterk dalend \\
\hline Andere bedrijfssectoren & 28 & - \\
\hline \multicolumn{3}{|l|}{ HBO bednijfsinformatica } \\
\hline Overige commerciële dienstverlening & 29 & stijgend \\
\hline Overheid & 16 & sterk stijgend \\
\hline Bank- en verzekeringswezen & 12 & sterk dalend \\
\hline Handel & 11 & sterk stijgend \\
\hline Andere bedrijfssectoren & 32 & - \\
\hline \multicolumn{3}{|l|}{ HBO toerisme en recreatie } \\
\hline Transport, opslag en communicatie & 41 & dalend \\
\hline Andere bedrijfssectoren & 59 & - \\
\hline \multicolumn{3}{|l|}{ HBO commerciële economie } \\
\hline Handel & 22 & sterk dalend \\
\hline Bank- en verzekeringswezen & 18 & sterk dalend \\
\hline Overige commerciële dienstverlening & 15 & sterk stijgend \\
\hline Metaal en elektrotechniek & 11 & dalend \\
\hline Andere bedrijfssectoren & 35 & - \\
\hline \multicolumn{3}{|l|}{ HBO technische bedrijfskunde } \\
\hline Handel & 18 & sterk dalend \\
\hline Overige commerciële dienstverlening & 17 & sterk stijgend \\
\hline Andere bedrijfssectoren & 65 & - \\
\hline \multicolumn{3}{|l|}{ HBO bestuurlijk-juridisch } \\
\hline Overheid & 51 & sterk dalend \\
\hline Overige commerciële dienstverlening & 23 & sterk stijgend \\
\hline Andere bedrijfssectoren & 26 & $\cdot$ \\
\hline $\begin{array}{c}\text { HBO sociaal-cultureel } \\
\text { Kwartaire diensten }\end{array}$ & 48 & stijgend \\
\hline
\end{tabular}


Tabel 3.17 (vervolg)

Belangrijkste bedrijfssectoren per opleidingstype, gemiddelde 1994-1995

\begin{tabular}{|c|c|c|}
\hline Opleidingstype & $\%$ & $\begin{array}{l}\text { trend } \\
1994-' 95\end{array}$ \\
\hline $\begin{array}{l}\text { Overheid } \\
\text { Overige commerciële dienstverlening } \\
\text { Andere bedrijfssectoren }\end{array}$ & $\begin{array}{r}27 \\
8 \\
17\end{array}$ & $\begin{array}{l}\text { dalend } \\
\text { stijgend } \\
\text { - }\end{array}$ \\
\hline $\begin{array}{l}\text { HBO kunst } \\
\text { Kwartaire diensten } \\
\text { Overige commerciële dienstverlening } \\
\text { Overheid } \\
\text { Handel } \\
\text { Andere bedrijfssectoren }\end{array}$ & $\begin{array}{r}44 \\
21 \\
15 \\
7 \\
13\end{array}$ & $\begin{array}{l}\text { dalend } \\
\text { dalend } \\
\text { sterk stijgend } \\
\text { sterk stijgend } \\
\text { - }\end{array}$ \\
\hline $\begin{array}{l}\text { HBO politie en defensie } \\
\text { Overheid } \\
\text { Andere bedrijfssectoren }\end{array}$ & $\begin{array}{l}70 \\
30\end{array}$ & $\begin{array}{l}\text { stijgend } \\
\text { - }\end{array}$ \\
\hline wo & & \\
\hline $\begin{array}{l}\text { WO letteren } \\
\text { Overheid } \\
\text { Kwartaire diensten } \\
\text { Overige commerciële dienstverlening } \\
\text { Andere bedrijfssectoren }\end{array}$ & $\begin{array}{l}52 \\
16 \\
14 \\
18\end{array}$ & $\begin{array}{l}\text { constant } \\
\text { sterk stijgend } \\
\text { sterk dalend } \\
-\end{array}$ \\
\hline $\begin{array}{l}\text { WO theologisch } \\
\text { Kwartaire diensten } \\
\text { Andere bedrijfssectoren }\end{array}$ & $\begin{array}{l}75 \\
25\end{array}$ & constant \\
\hline $\begin{array}{l}\text { WO landbouw en milieukunde } \\
\text { Overheid } \\
\text { Overige commerciële dienstverlening } \\
\text { Andere bedrijfssectoren }\end{array}$ & $\begin{array}{l}39 \\
26 \\
34\end{array}$ & $\begin{array}{l}\text { stijgend } \\
\text { constant } \\
\text { - }\end{array}$ \\
\hline $\begin{array}{l}\text { WO wiskunde en natuurwetenschappen } \\
\text { Overheid } \\
\text { Kwartaire diensten } \\
\text { Overige commerciële dienstveriening } \\
\text { Andere bedrijfssectoren }\end{array}$ & $\begin{array}{l}44 \\
18 \\
16 \\
22\end{array}$ & $\begin{array}{l}\text { sterk stijgend } \\
\text { constant } \\
\text { constant } \\
\text { - }\end{array}$ \\
\hline $\begin{array}{l}\text { WO (weg- en water)bouwkunde } \\
\text { Overige commerciële dienstverlening } \\
\text { Overheid } \\
\text { Andere bedrijfssectoren }\end{array}$ & $\begin{array}{l}51 \\
28 \\
21\end{array}$ & $\begin{array}{l}\text { dalend } \\
\text { sterk stijgend } \\
\text { - }\end{array}$ \\
\hline $\begin{array}{l}\text { WO werktuigbouwkunde } \\
\text { Metaal en elektrotechniek } \\
\text { Andere bedrijfssectoren }\end{array}$ & $\begin{array}{l}33 \\
67\end{array}$ & $\begin{array}{l}\text { sterk stijgend } \\
\text { - }\end{array}$ \\
\hline $\begin{array}{l}\text { WO elektrotechniek en technische inform } \\
\text { Metaal en elektrotechniek } \\
\text { Overige commerciële dienstverlening } \\
\text { Andere bedrijfssectoren }\end{array}$ & $\begin{array}{l}32 \\
24 \\
43\end{array}$ & $\begin{array}{l}\text { sterk stijgend } \\
\text { sterk dalend } \\
\text { - }\end{array}$ \\
\hline
\end{tabular}


Tabel 3.17 (vervolg)

Belangrijkste bedrijfssectoren per opleidingstype, gemiddelde 1994-1995

\begin{tabular}{lll}
\hline Opleidingstype & $\%$ & trend
\end{tabular}

1994-'95

WO dier-, genees- en tandheelkunde

Kwartaire diensten

Overheid

Andere bedrijfssectoren

constant

WO farmacie

Diverse bedrijfssectoren

WO econom(etr)ie en accountancy

Overige commerciële dienstverlening

Overheid

Bank- en verzekeringswezen

Handel

Andere bedrijfssectoren

WO bedrijfskunde

Overige commerciële dienstverlening

Andere bedrijfssectoren

stijgend

WO informatica

Diverse bedrijfssectoren

WO juridisch

Overheid

Overige commerciële dienstverlening

Bank- en verzekeringswezen

Kwartaire diensten

Andere bedrijfssectoren

constant sterk stijgend constant

sterk stijgend

wO bestuurlijk

Overige commerciële dienstverlening

Overheid

Andere bedrijfssectoren

WO sociaal-cultureel

Overheid

Kwartaire diensten

Overige commerciële dienstverlening

Andere bedrijfssectoren

sterk dalend

dalend

sterk stijgend

sterk stijgend

wo kunst

Overheid

Kwartaire diensten

Andere bedrijfssectoren

sterk dalend sterk dalend

dalend

stijgend sterk stijgend

sterk dalend sterk stijgend

\section{Bron: CBS/ROA}

Een uitgebreidere versie van deze tabel is opgenomen in een aparte uitgave die bij het ROA verkregen kan worden: Verdeeltabellen van bedrijfssectoren, beroepsklassen en opleidingstypen.

- Deze bedrijfssectoren hebben elk een werkgelegenheidsaandeel van minder dan $3 \%$.

- Deze bedrijfssectoren hebben elk minder dan 2.500 werkenden. 
Tabel 3.18

Uitwijkmogelijkheden naar verschillende bedrijfsklassen per opleidingstype, gemiddelde 1994-1995

\begin{tabular}{lll}
\hline Opleidingstype & $\begin{array}{l}\text { Gini-Hirschman } \\
\text { spreidingsindex }\end{array}$ & typering \\
&
\end{tabular}

\section{BASISONDERWJS}

Basisonderwijs

MAVO, VBO

MAVO, onderbouw HAVONWO

VBO landbouw en natuurlijke omgeving

VBO bouwtechniek

VBO installatietechniek

VBO mechanische techniek

VBO motorvoertuigentechniek

VBO elektrotechniek

VBO grafische techniek

VBO consumptieve techniek

VBO textiel- en ledertechniek

VBO haven en vervoer

VBO administratie

VBO verkoop en handel

VBO verzorging

gemiddeld

laag

gemiddeld

laag

hoog

gemiddeld

gemiddeld

laag

gemiddeld gemiddeld

laag

gemiddeld

gemiddeld gemiddeld gemiddeld

\section{HAVONWO, MBO/LLW}

HAVONWO bovenbouw MBO/LLW landbouw en natuurlijke omgeving

MBO technisch laboratorium

MBO/LLW bouwkunde

MBO/LLW weg- en waterbouwkunde

MBO/LLW metaalkunde

MBO/LLW fijnmechanische techniek

MBO/LLW werktuigbouwkunde

MBO/LLW motorvoertuigentechniek

MBO/LLW elektrotechniek

MBO/LLW grafische techniek

MBO/LLW consumptieve techniek

MBO/LLW procestechniek

MBO/LLW textiel- en ledertechniek

MBO/LLW haven en vervoer

MBO/LLW verpleging en medische assistentie

MBO/LLW medisch laboratorium

MBO/LLW handel

MBO/LLW administratief

MBO toerisme en recreatie

MBO/LLW commercieel

MBO/LLW secretarieel

MBO bestuurlijk-juridisch

MBO sociaal-cultureel

MBO/LLW verzorging

MBO/LLW horeca en uiterlijke verzorging

MBO politie en defensie

laag

gemiddeld

laag

laag

gemiddeld

gemiddeld

hoog

laag

gemiddeld

laag

laag

gemiddeld

gemiddeld

gemiddeld

erg laag

laag

gemiddeld

hoog

gemiddeld

gemiddeld

gemiddeld

erg laag

laag

laag

gemiddeld

laag 
Tabel 3.18 (vervolg)

Uitwijkmogelijkheden naar verschillende bedrijfsklassen per opleidingstype, gemiddelde 1994-1995

\begin{tabular}{lll}
\hline Opleidingstype & $\begin{array}{l}\text { Gini-Hirschman } \\
\text { spreidingsindex }\end{array}$
\end{tabular}

HBO

HBO onderwijs $\quad 0,51$

HBO tolk en vertaler $\quad 0,92$

$\mathrm{HBO}$ landbouw en milieukunde $\quad 0,87$

HBO technisch laboratorium $\quad 0,91$

HBO (weg- en water)bouwkunde $\quad 0,82$

HBO werktuigbouwkunde $\quad 0,94$

HBO elektrotechniek en technische informatica $\quad 0,94$

HBO haven en vervoer

HBO medisch laboratorium

$H B O$ verpleging en paramedisch

HBO bedrijfseconomie

HBO accountancy

HBO bedrijfsinformatica

HBO toerisme en recreatie

HBO commerciële economie

$H B O$ technische bedrijfskunde

HBO bestuurlijk-juridisch

HBO sociaal-cultureel

HBO kunst

HBO politie en defensie

0,91

0,72

erg laag

gemiddeld

gemiddeld

gemiddeld

gemiddeld

hoog

hoog

hoog

erg laag

erg laag

gemiddeld

gemiddeld

gemiddeld

gemiddeld

gemiddeld

hoog

laag

laag

laag

erg laag

$\begin{array}{ll}0,79 & \text { laag } \\ 0,63 & \text { laag } \\ 0,88 & \text { gemiddeld } \\ 0,85 & \text { gemiddeld } \\ 0,73 & \text { laag } \\ 0,95 & \text { hoog } \\ 0,89 & \text { gemiddeld } \\ 0,29 & \text { erg laag } \\ 0,70 & \text { laag } \\ 0,87 & \text { gemiddeld } \\ 0,92 & \text { gemiddeld } \\ 0,82 & \text { gemiddeld } \\ 0,80 & \text { laag } \\ 0,73 & \text { laag } \\ 0,83 & \text { gemiddeld } \\ 0,69 & \text { laag }\end{array}$

laag

Wo letteren

WO theologisch

WO landbouw en milieukunde

WO wiskunde en natuurwetenschappen

WO (weg-en water)bouwkunde

WO werktuigbouwkunde

WO elektrotechniek en technische informatica

WO dier-, genees- en tandheelkunde

WO farmacie

WO econom(etr)ie en accountancy

WO bedrijfskunde

WO informatica

WO juridisch

WO bestuurliik

Wo kunst

Bron: ROA 
Tabel 3.19

Overzicht van opleidingstypen waarvan op de arbeidsmarkt (sterke) concurrentie wordt ondervonden

\begin{tabular}{lc}
\hline Opleidingstype & concurrentie \\
\hline Basisonderwijs & \\
& \\
VBO verzorging & 0.72 \\
MAVO, onderbouw HAVONWO & 0.67 \\
VBO textiel- en ledertechniek & 0.63 \\
MBO/LLW haven en vervoer & 0.61 \\
VBO verkoop en handel & 0.60 \\
VBO mechanische techniek & 0.56 \\
VBO haven en vervoer & 0.54 \\
VBO motorvoertuigentechniek & 0.54 \\
MBO/LLW handel & 0.52 \\
VBO administratie & 0.50 \\
MBO/LLW textiel- en ledertechniek & 0.48 \\
HAVONWO bovenbouw & 0.48 \\
VBO consumptieve techniek & 0.43 \\
VBO bouwtechniek & 0.43 \\
VBO elektrotechniek & 0.40 \\
VBO landbouw en natuurlijke omgeving & 0.37 \\
MBO/LLW verzorging & 0.34 \\
MBO/LLW commercieel & 0.31 \\
MBO/LLW werktuigbouwkunde & 0.30
\end{tabular}

MAVO, onderbouw HAVONWO

$\begin{array}{ll}\text { VBO administratie } & 0.94 \\ \text { HAVO/WO bovenbouw } & 0.94 \\ \text { MBO/LLW handel } & 0.90 \\ \text { VBO verkoop en handel } & 0.79 \\ \text { MBO/LLW commercieel } & 0.78 \\ \text { VBO verzorging } & 0.77 \\ \text { VBO textiel- en ledertechniek } & 0.74 \\ \text { MBO/LLW textiel- en ledertechniek } & 0.69 \\ \text { Basisonderwijs } & 0.67 \\ \text { MBO/LLW administratief } & 0.63 \\ \text { HBO bedrijfseconomie } & 0.63 \\ \text { MBO bestuurlijk-juridisch } & 0.63 \\ \text { MBO/LLW secretarieel } & 0.58 \\ \text { HBO bestuurlijk-juridisch } & 0.58 \\ \text { MBO toerisme en recreatie } & 0.53 \\ \text { HBO commerciële economie } & 0.53 \\ \text { HBO toerisme en recreatie } & 0.47 \\ \text { MBO/LWW haven en vervoer } & 0.46 \\ \text { HBO accountancy } & 0.42 \\ \text { MBO/LLW verzorging } & 0.41 \\ \text { MBO sociaal-cultureel } & 0.40 \\ \text { HBO landbouw en milieukunde } & 0.40 \\ \text { HBO tolk en vertaler } & 0.38 \\ \text { MBO/LLW horeca en uiterlijke verzorging } & 0.35 \\ \text { MBO/LLW fijnmechanische techniek } & 0.32 \\ \text { VBO consumptieve techniek } & 0.30\end{array}$


Tabel 3.19 (vervolg)

Overzicht van opleidingstypen waarvan op de arbeidsmarkt (sterke) concurrentie wordt ondervonden

VBO landbouw en natuurlijke omgeving

MBO/LLW landbouw en natuurlijke omgeving

HBO landbouw en milieukunde

Basisonderwijs

VBO bouwtechniek

MBO/LLW bouwkunde

Basisonderwijs

0.43

VBO mechanische techniek

VBO installatietechniek

VBO mechanische techniek

VBO mechanische techniek

MBO/LLW metaalkunde

MBOLLWW werktuigbourwkunde

Basisonderwijs

0.56

VBO motorvoertuigentechniek

0.50

MBO/LLW haven en vervoer

0.48

VBO haven en vervoer

0.46

VBO elektrotechniek

0.44

VBO installatietechniek

0.40

VBO bouwtechniek

VBO motorvoertuigentechniek

MBO/LLW motorvoertuigentechniek

VBO haven en vervoer

MBO/LLW haven en vervoer

Basisonderwijs

VBO mechanische techniek

VBO elektrotechniek

MBOLLWW werktuigbouwkunde

\section{VBO elektrotechniek}

MBO/LLW elektrotechniek

VBO mechanische techniek

MBO/LLW werktuigbouwkunde

Basisonderwijs

MBO/LLW haven en vervoer

VBO haven en vervoer

VBO grafische techniek 
Tabel 3.19 (vervolg)

Overzicht van opleidingstypen waarvan op de arbeidsmarkt (sterke) concurrentie wordt ondervonden

\section{VBO consumptieve techniek}

MBO/LLW consumptieve techniek $\quad 0.75$

Basisonderwijs $\quad 0.43$

VBO verzorging $\quad 0.36$

VBO verkoop en handel $\quad 0.31$

MAVO, onderbouw HAVOMWO $\quad 0.30$

VBO textiel- en ledertechniek

VBO verzorging $\quad 0.91$

MBO/LLW textiel- en ledertechniek $\quad 0.81$

0.81

MAVO, onderbouw HAVOMWO $\quad 0.74$

$\begin{array}{ll}\text { VBO administratie } & 0.68\end{array}$

MBO/LLW handel $\quad 0.67$

0.63

HAVOMWO bovenbouw $\quad 0.60$

MBO/LLW verzorging $\quad 0.50$

MBO/LLW commercieel $\quad 0.43$

MBO/LW administratief $\quad 0.40$

HBO bedrijfseconomie $\quad 0.39$

MBO/LLW horeca en uiterlijke verzorging $\quad 0.33$

VBO haven en vervoer

MBO/LW haven en vervoer $\quad 0.74$

VBO motorvoertuigentechniek $\quad 0.59$

Basisonderwijs $\quad 0.54$

VBO mechanische techniek $\quad 0.46$

VBO elektrotechniek $\quad 0.32$

VBO administratie

MAVO, onderbouw HAVONWO

HAVONWO bovenbouw $\quad 0.90$

MBO/LW handel $\quad 0.86$

MBO/LW administratief $\quad 0.80$

MBO/LLW commercieel $\quad 0.78$

HBO bedrijfseconomie $\quad 0.76$

MBO bestuurlijk-juridisch $\quad 0.70$

VBO verkoop en handel $\quad 0.70$

VBO textiel- en ledertechniek $\quad 0.68$

$\begin{array}{ll}\text { VBO verzorging } & 0.67\end{array}$

HBO bestuurlijk-juridisch $\quad 0.63$

MBO/LLW textiel- en ledertechniek $\quad 0.61$

HBO accountancy 0.56

MBO toerisme en recreatie $\quad 0.55$

MBO/LLW secretarieel $\quad 0.55$

HBO commerciële economie $\quad 0.51$

Basisonderwijs $\quad 0.50$

HBO toerisme en recreatie $\quad 0.45$

$\mathrm{HBO}$ landbouw en milieukunde $\quad 0.41$ 
Tabel 3.19 (vervolg)

Overzicht van opleidingstypen waarvan op de arbeidsmarkt (sterke) concurrentie wordt ondervonden

\section{VBO verkoop en handel}

$\begin{array}{ll}\text { MBO/LLW handel } & 0.83\end{array}$

$\begin{array}{ll}\text { VBO verzorging } & 0.83\end{array}$

MBO/LLW textiel- en ledertechniek $\quad 0.83$

VBO textiel- en ledertechniek $\quad 0.81$

MAVO, onderbouw HAVONWO $\quad 0.79$

HAVOMWO bovenbouw $\quad 0.63$

Basisonderwijs $\quad 0.60$

MBO/LLW commercieel $\quad 0.50$

MBO/LLW fijnmechanische techniek $\quad 0.42$

HBO commerciële economie $\quad 0.35$

$\mathrm{HBO}$ bedrijfseconomie $\quad 0.34$

MBO/LLW haven en vervoer $\quad 0.34$

MBO/LLW administratief $\quad 0.34$

MBO/LLW verzorging $\quad 0.33$

MBO/LLW horeca en uiterlijke verzorging 0.33

VBO consumptieve techniek $\quad 0.31$

\section{VBO verzorging}

VBO textiel en ledertechniek 0.91

MAVO, onderbouw HAVOMWO $\quad 0.77$

MBO/LLW textiel- en ledertechniek $\quad 0.74$

$\begin{array}{ll}\text { Basisonderwijs } & 0.72\end{array}$

MBO/LLW handel $\quad 0.69$

VBO administratie $\quad 0.67$

HAVONWO bovenbourw $\quad 0.62$

MBO/LLW verzorging $\quad 0.60$

MBO/LLW horeca en uiterlijke verzorging $\quad 0.44$

$\begin{array}{ll}\text { MBORLW commercieel } & 0.42\end{array}$

VBO consumptieve techniek $\quad 0.36$

$\begin{array}{ll}\text { MBO sociaal-cultureel } & 0.35\end{array}$

MBORLW administratief $\quad 0.32$

$\begin{array}{ll}\mathrm{HBO} \text { bedrijfseconomie } & 0.32\end{array}$

$\begin{array}{ll}\text { MBO/LLW fijnmechanische techniek } & 0.31\end{array}$

VBO bewaking

\section{HAVONWO bovenbouw}

MAVO, onderbouw HAVOMWO 0.94

VBO administratie $\quad 0.90$

MBO/LLW handel $\quad 0.83$

MBO/LLW commercieel $\quad 0.82$

$\begin{array}{ll}\text { MBO/LLW secretarieel } & 0.69\end{array}$ 
Tabel 3.19 (vervolg)

Overzicht van opleidingstypen waarvan op de arbeidsmarkt (sterke) concurrentie wordt ondervonden

Opleidingstype

concurrentie-index

$\begin{array}{ll}\text { HBO bedrijfseconomie } & 0.69 \\ \text { MBO bestuurlijk-juridisch } & 0.69 \\ \text { MBO/LLW administratief } & 0.65 \\ \text { HBO bestuurlijk-juridisch } & 0.65 \\ \text { VBO verkoop en handel } & 0.63 \\ \text { VBO textiel- en ledertechniek } & 0.60 \\ \text { HBO commerciële economie } & 0.59 \\ \text { MBO/LLW textiel- en ledertechniek } & 0.58 \\ \text { MBO toerisme en recreatie } & 0.58 \\ \text { HBO toerisme en recreatie } & 0.54 \\ \text { Basisonderwijs } & 0.48 \\ \text { HBO tolk en vertaler } & 0.47 \\ \text { HBO accountancy } & 0.45 \\ \text { MBO sociaal-cultureel } & 0.42 \\ \text { HBO technische bedrijfskunde } & 0.42 \\ \text { HBO landbouw en milieukunde } & 0.41 \\ \text { MBO/LLW haven en vervoer } & 0.37 \\ \text { WO econom(etr)ie en accountancy } & 0.37 \\ \text { MBO/LLW verzorging } & 0.35 \\ \text { WO sociaal-cultureel } & 0.33 \\ \text { WO landbouw en milieukunde } & 0.32 \\ \text { MBO/LLW horeca en uterlike verzorging } & 0.32\end{array}$

MBO/LLW horeca en uiterlijke verzorging 0.32

MBO/LLW landbouw en natuurlijke orngeving

VBO landbouw en natuurlijke omgeving 0.98

HBO landbouw en milieukunde $\quad 0.53$

MBO technisch laboratorium

$\begin{array}{ll}\text { HBO technisch laboratorium } & 0.97\end{array}$

HBO medisch laboratorium $\quad 0.41$

MBO/LLW fijnmechanische techniek $\quad 0.35$

\section{MBORLW bouwkunde}

$\begin{array}{ll}\text { VBO bouwtechniek } & 0.87\end{array}$

MBO/LLW weg- en waterbouwkunde $\quad 0.37$

VBO installatietechniek $\quad 0.30$

MBORLW weg- en waterbouwkunde

$\begin{array}{ll}\text { HBO (weg-en water)bouwkunde } & 0.57\end{array}$

MBORLW werktuigbouwkunde $\quad 0.39$

$\begin{array}{ll}\text { MBORLW bouwkunde } & 0.37\end{array}$

$\begin{array}{ll}\text { HBO werktuigbouwkunde } & 0.34\end{array}$

\section{MBORLW metaalkunde}

$\begin{array}{ll}\text { VBO mechanische techniek } & 0.85\end{array}$

$\begin{array}{ll}\text { MBORLW werktuigbouwkunde } & 0.65\end{array}$ 
Tabel 3.19 (vervoig)

Overzicht van opleidingstypen waarvan op de arbeidsmarkt (sterke) concurrentie wordt ondervonden

Opleidingstype

concurrentie-index

MBO/LLW fijnmechanische techniek

$\begin{array}{ll}\text { VBO verkoop en handel } & 0.42\end{array}$

MBO/LLW textiel- en ledertechniek $\quad 0.39$

$\begin{array}{ll}\text { MBO/LLW handel } & 0.37\end{array}$

MBO technisch laboratorium $\quad 0.35$

HBO technisch laboratorium $\quad 0.32$

MAVO, onderbouw HAVONWO 0.32

$\begin{array}{ll}\text { VBO verzorging } & 0.31\end{array}$

MBORLWW werktuigbouwkunde

MBO/LLW metaalkunde $\quad 0.65$

VBO mechanische techniek $\quad 0.62$

HBO werktuigbouwkunde $\quad 0.52$

MBO/LLW elektrotechniek $\quad 0.46$

VBO elektrotechniek $\quad 0.41$

MBO/LLW haven en vervoer $\quad 0.32$

VBO motorvoertuigentechniek $\quad 0.31$

Basisonderwijs $\quad 0.30$

$\begin{array}{ll}\mathrm{HBO} \text { technische bedrijfskunde } & 0.30\end{array}$

MBOILW motorvoertuigentechniek

$\begin{array}{ll}\text { VBO motorvoertuigentechniek } & 0.88\end{array}$

MBO/LLW elektrotechniek

$\begin{array}{ll}\text { VBO elektrotechniek } & 0.89\end{array}$

MBO/LLW werktuigbouwkunde $\quad 0.46$

HBO elektrotechniek en technische informatica $\quad 0.31$

MBO/LLW grafische techniek

VBO grafische techniek

0.92

MBO/LLW consumptieve techniek

VBO consumptieve techniek

0.75

MBO/LLW procestechniek

MBO/LLW textiel- en ledertechniek

$\begin{array}{ll}\text { VBO verkoop en handel } & 0.83 \\ \text { VBO textiel- en ledertechniek } & 0.81 \\ \text { MBO/LWW handel } & 0.76 \\ \text { VBO verzorging } & 0.74 \\ \text { MAVO, onderbouw HAVONWO } & 0.69 \\ \text { VBO administratie } & 0.61 \\ \text { HAVOMWO bovenbouw } & 0.58\end{array}$ 
Tabel 3.19 (vervolg)

Overzicht van opleidingstypen waarvan op de arbeidsmarkt (sterke) concurrentie wordt ondervonden

\begin{tabular}{lc}
\hline Opleidingstype & concurrentie-in \\
\hline & \\
Basisonderwijs & 0.48 \\
MBO/LLW commercieel & 0.46 \\
MBO/LLW fijnmechanische techniek & 0.39 \\
MBO toerisme en recreatie & 0.30 \\
& \\
MBO/LLW haven en vervoer & \\
VBO haven en vervoer & \\
Basisonderwijs & 0.74 \\
VBO motorvoertuigentechniek & 0.61 \\
VBO mechanische techniek & 0.55 \\
MAVO, onderbouw HAVONWO & 0.48 \\
HBO haven en vervoer & 0.46 \\
VBO administratie & 0.40 \\
MBO/LLW handel & 0.40 \\
HAVONWO bovenbouw & 0.39 \\
VBO elektrotechniek & 0.37 \\
VBO verkoop en handel & 0.35 \\
MBO/LLW werktuigbouwkunde & 0.34 \\
MBO/LLW commercieel & 0.32 \\
\end{tabular}

MBORLW verpleging en medische assistentie

HBO verpleging en paramedisch $\quad 0.62$

MBO sociaal-cultureel $\quad 0.48$

MBO/LLW verzorging $\quad 0.30$

MBO/LLW medisch laboratorium

\section{MBOILLW handel}

MAVO, onderbouw HAVONWO $\quad 0.90$

VBO administratie $\quad 0.86$

VBO verkoop en handel $\quad 0.83$

HAVONWO bovenbouw $\quad 0.83$

MBO/LLW textiel- en ledertechniek $\quad 0.76$

MBO/LLW commercieel $\quad 0.75$

$\begin{array}{ll}\text { VBO verzorging } & 0.69\end{array}$

VBO textiel-en ledertechniek $\quad 0.67$

HBO bedriffseconomie $\quad 0.55$

MBO/LLW administratief $\quad 0.55$

HBO commerciële economie $\quad 0.54$

Basisonderwijs $\quad 0.52$

MBO bestuurlijk-juridisch $\quad 0.51$

HBO bestuuriijk-juridisch $\quad 0.51$

MBO/LLW secretarieel $\quad 0.49$

MBO toerisme en recreatie $\quad 0.45$

HBO toerisme en recreatie $\quad 0.40$

MBO/LLW haven en vervoer $\quad 0.39$

HBO accountancy $\quad 0.37$

HBO landbouw en milieukunde $\quad 0.37$ 
Tabel 3.19 (vervolg)

Overzicht van opleidingstypen waarvan op de arbeidsmarkt (sterke) concurrentie wordt ondervonden

Opleidingstype concurrentie-index

MBO/LLW fijnmechanische techniek

MBO/LLW administratief

HBO bedrijfseconomie

0.94

HBO accountancy

0.80

VBO administratie

0.80

HAVOMWO bovenbouw

0.65

MAVO, onderbouw HAVOMWO

0.63

MBO bestuurlijk-juridisch

0.57

MBO/LLW commercieel

0.57

MBO/LLW handel

0.55

HBO bestuurlijk-juridisch

0.50

MBO toerisme en recreatie

0.46

VBO textiel- en ledertechniek

0.40

HBO commerciële economie

0.40

MBO/LLW secretariee

0.37

WO econom(etr)ie en accountancy

0.35

VBO verkoop en handel

0.34

VBO verzorging

MBO toerisme en recreatie

HBO toerisme en recreatie

0.94

HAVONWO bovenbouw

0.58

VBO administratie

0.55

MBO/LLW secretarieel

0.54

MAVO, onderbouw HAVONWO

0.53

MBO/LLW administratief

0.46

MBO/LLW handel

0.45

$H B O$ bedrijfseconomie

0.43

MBO/LLW commercieel

0.41

$\mathrm{HBO}$ tolk en vertaler

0.39

MBO bestuurlijk-juridisch

0.37

HBO bestuurlijk-juridisch

0.33

MBO/LLW textiel- en ledertechniek

0.30

\section{MBO/LLW commercieel}

HAVOMWO bovenbouw

VBO administratie

0.78

MAVO, Onderbouw HAVOMWO

0.78

HBO commerciële economie

0.77

MBO/LLW handel

0.75

MBO bestuurlijk-juridisch

0.73

HBO bestuuriijk-juridisch

0.65

HBO bedrijfseconomie

0.57

MBO/LLW administratief

MBO/LLW secretarieel

0.54

VBO verkoop en handel

0.50

MBO/LLW textiel- en ledertechniek

0.46

VBO textiel- en ledertechniek

0.43

VBO verzorging 
Tabel 3.19 (vervolg)

Overzicht van opleidingstypen waarvan op de arbeidsmarkt (sterke) concurrentie wordt ondervonden

\begin{tabular}{lc}
\hline Opleidingstype & concurrentie \\
\hline & \\
MBO toerisme en recreatie & 0.41 \\
HBO toerisme en recreatie & 0.39 \\
HBO landboun en milieukunde & 0.39 \\
HBO accountancy & 0.36 \\
WO econom(etr)ie en accountancy & 0.33 \\
HBO tolk en vertaler & 0.33 \\
Basisonderwijs & 0.31 \\
MBO/LLW haven en vervoer & 0.30 \\
HBO technische bedrijfskunde & 0.30
\end{tabular}

\section{MBO/LLW secretarieel}

HAVOMWO bovenbouw $\quad 0.69$

MAVO, onderbouw HAVONWO $\quad 0.58$

HBO tolk en vertaler $\quad 0.57$

HBO toerisme en recreatie $\quad 0.55$

VBO administratie $\quad 0.55$

MBO/LLW commercieel $\quad 0.54$

MBO toerisme en recreatie $\quad 0.54$

$\begin{array}{ll}\text { MBO bestuurlijk-juridisch } & 0.48\end{array}$

$\begin{array}{ll}\mathrm{HBO} \text { bestuurlijk-juridisch } & 0.41\end{array}$

$\begin{array}{ll}\text { MBO/LLW administratief } & 0.37\end{array}$

$\begin{array}{ll}\mathrm{HBO} \text { bedrijfseconomie } & 0.37\end{array}$

$\begin{array}{ll}\text { HBO commerciële economie } & 0.30\end{array}$

MBO bestuurlijk-juridisch

$\begin{array}{ll}\text { HBO bestuurlijk-juridisch } & 0.75\end{array}$

MBO/LLW commercieel $\quad 0.73$

VBO administratie $\quad 0.70$

HAVONWO bovenbouw $\quad 0.69$

MAVO, onderbouw HAVONWO $\quad 0.63$

HBO bedrijfseconomie $\quad 0.55$

HBO commerciële economie $\quad 0.53$

MBO/LLW handel $\quad 0.51$

MBO/LLW secretarieel $\quad 0.48$

HBO landbouw en milieukunde $\quad 0.40$

HBO toerisme en recreatie $\quad 0.38$

MBO toerisme en recreatie $\quad 0.37$

HBO accountancy $\quad 0.35$

WO econom(etr)ie en accountancy

wo juridisch 0.33

WO bestuurlijk $\quad 0.33$

WO landbouw en milieukunde $\quad 0.31$

MBO sociaal-cultureel

HBO sociaal-cultureel $\quad 0.77$

MBO/LLW verzorging $\quad 0.65$

MBO/LLW verpleging en medische assistentie $\quad 0.48$

WO sociaal-cultureel $\quad 0.42$

HAVOMWO bovenbouw $\quad 0.42$

MAVO, onderbouw HAVOMWO 
Tabel 3.19 (vervolg)

Overzicht van opleidingstypen waarvan op de arbeidsmarkt (sterke) concurrentie wordt ondervonden

\begin{tabular}{lc}
\hline Opleidingstype & concurrenti \\
\hline VBO verzorging & 0.35 \\
VBO administratie & 0.35 \\
MBO/LLW verzorging & \\
MBO sociaal-cultureel & \\
VBO verzorging & 0.65 \\
VBO textiel- en ledertechniek & 0.60 \\
MBO/LLW horeca en uiterlijke verzorging & 0.50 \\
MAVO, onderbouw HAVOMWO & 0.46 \\
HAVOMWO bovenbouw & 0.41 \\
VBO administratie & 0.35 \\
Basisonderwijs & 0.35 \\
VBO verkoop en handel & 0.34 \\
MBO/LW verpleging en medische assistentie & 0.33 \\
\end{tabular}

MBORLW horeca en uiterlijke verzorging

$\begin{array}{ll}\text { MBO/LLW verzorging } & 0.46 \\ \text { VBO verzorging } & 0.44 \\ \text { MAVO, onderbouw HAVONWO } & 0.35 \\ \text { VBO verkoop en handel } & 0.33 \\ \text { VBO textiel- en ledertechniek } & 0.33 \\ \text { HAVONWO bovenbouw } & 0.32\end{array}$

MBO politie en defensie

HBO politie en defensie

HBO onderwijs

HBO tolk en vertaler

$\begin{array}{ll}\text { MBO/LLW secretarieel } & 0.57 \\ \text { HAVONWO bovenbouw } & 0.47 \\ \text { MBO toerisme en recreatie } & 0.39 \\ \text { HBO toerisme en recreatie } & 0.39 \\ \text { MAVO, onderbouw HAVONWO } & 0.38 \\ \text { VBO administratie } & 0.37 \\ \text { MBO/LLW commercieel } & 0.33 \\ \text { WO letteren } & 0.30\end{array}$

HBO landbouw en milieukunde

WO landbouw en milieukunde $\quad 0.61$

MBO/LLW landbouw en natuurijke omgeving $\quad 0.53$

VBO landbouw en natuurlijke omgeving $\quad 0.49$

HBO bestuurlijk-juridisch $\quad 0.43$

HAVONWO bovenbouw $\quad 0.41$

VBO administratie $\quad 0.41$

MAVO, onderbouw HAVOMWO $\quad 0.40$ 
Tabel 3.19 (vervolg)

Overzicht van opleidingstypen waarvan op de arbeidsmarkt (sterke) concurrentie wordt ondervonden

Opleidingstype

concurrentie-index

MBO bestuurlijk-juridisch

0.40

MBO/LLW commercieel

0.39

MBO/LLW handel

0.37

HBO technische bedrijfskunde

0.35

HBO commerciële economie

0.34

WO werktuigbouwkunde

0.34

HBO werktuigbouwkunde

HBO technisch laboratorium

MBO technisch laboratorium $\quad 0.97$

HBO medisch laboratorium $\quad 0.46$

$\begin{array}{ll}\text { MBO/LLW fijnmechanische techniek } & 0.32\end{array}$

HBO (weg-en water)bouwkunde

MBO/LLW weg- en waterbouwkunde $\quad 0.57$

WO (weg- en water)bouwkunde $\quad 0.50$

HBO werktuigbouwkunde $\quad 0.44$

HBO technische bedrijfskunde $\quad 0.34$

WO landbouw en milieukunde $\quad 0.33$

HBO werktuigbouwkunde

WO werktuigbouwkunde $\quad 0.72$

HBO technische bedrijfskunde $\quad 0.61$

MBO/LLW werktuigbouwkunde $\quad 0.52$

WO bedrijfskunde $\quad 0.51$

HBO (weg-en water)bouwkunde $\quad 0.44$

HBO elektrotechniek en technische informatica $\quad 0.43$

WO elektrotechniek en technische informatica $\quad 0.40$

WO landbouw en milieukunde $\quad 0.35$

$\mathrm{HBO}$ commerciële economie $\quad 0.35$

MBO/LLW weg- en waterbouwkunde $\quad 0.34$

HBO landbouw en milieukunde $\quad 0.30$

HBO elektrotechniek en technische informatica

WO elektrotechniek en technische informatica 0.87

$\begin{array}{ll}\text { HBO bedrijfsinformatica } & 0.86\end{array}$

WO informatica $\quad 0.80$

HBO technische bedrijfskunde $\quad 0.60$

WO werktuigbouwkunde $\quad 0.43$

HBO werktuigbouwkunde $\quad 0.43$

MBO/LLW elektrotechniek $\quad 0.31$

WO bedrijfskunde $\quad 0.31$

WO landbouw en milieukunde $\quad 0.31$

HBO haven en vervoer

MBO/LLW haven en vervoer 
Tabel 3.19 (vervolg)

Overzicht van opleidingstypen waarvan op de arbeidsmarkt (sterke) concurrentie wordt ondervonden

HBO medisch laboratorium

HBO technisch laboratorium

HBO verpleging en paramedisch

MBO/LLW verpleging en medische assistentie

HBO bedrijfseconomie

MBO/LLW administratief

HBO accountancy

0.88

VBO administratie

0.76

HAVOMWO bovenbouw

0.69

MAVO, OnderbouW HAVONWO

0.63

MBO/LLW commercieel

0.57

HBO bestuurlijk-juridisch

0.56

WO econom(etr)ie en accountancy 0.56

MBO/LLW handel 0.55

MBO bestuurlijk-juridisch $\quad 0.55$

HBO commerciële economie $\quad \cdot 0.49$

MBO toerisme en recreatie $\quad 0.43$

VBO textiel- en ledertechniek $\quad 0.39$

MBO/LLW secretarieel $\quad 0.37$

VBO verkoop en handel $\quad 0.34$

$\mathrm{HBO}$ technische bedrijfskunde $\quad 0.34$

VBO verzorging 0.32

WO bedriifskunde $\quad 0.32$

HBO accountancy

HBO bedriifseconomie $\quad 0.88$

MBO/LLW administratief $\quad 0.80$

WO econom(etr)ie en accountancy $\quad 0.72$

VBO administratie $\quad 0.56$

WO bestuurlijk $\quad 0.54$

HBO bestuurlijk-juridisch $\quad 0.52$

HAVONWO bovenbouw $\quad 0.45$

MAVO, onderbouw HAVOMWO $\quad 0.42$

MBO/LW handel $\quad 0.37$

MBO/LLW commercieel $\quad 0.36$

$\mathrm{HBO}$ commerciële economie $\quad 0.36$

MBO bestuurlijk-juridisch $\quad 0.35$

$\begin{array}{ll}\text { WO bedrijfskunde } & 0.32\end{array}$

HBO bedrijfsinformatica

WO informatica $\quad 0.95$

WO elektrotechniek en technische informatica $\quad 0.73$

HBO technische bedrijfskunde $\quad 0.58$

WO werktuigbouwkunde $\quad 0.36$

WO wiskunde en natuurwetenschappen $\quad 0.30$ 
Tabel 3.19 (vervolg)

Overzicht van opleidingstypen waarvan op de arbeidsmarkt (sterke) concurrentie wordt ondervonden

\section{$\mathrm{HBO}$ toerisme en recreatie}

MBO toerisme en recreatie $\quad 0.94$

MBO/LLW secretarieel $\quad 0.55$

HAVONWO bovenbouW $\quad 0.54$

MAVO, onderbouw HAVOMWO $\quad 0.47$

VBO administratie $\quad 0.45$

MBO/LLW handel $\quad 0.40$

MBO/LLW commercieel $\quad 0.39$

$\begin{array}{ll}\mathrm{HBO} \text { tolk en vertaler } & 0.39\end{array}$

$\begin{array}{ll}\text { MBO bestuurlijk-juridisch } & 0.38\end{array}$

$\begin{array}{ll}\mathrm{HBO} \text { bestuurlijk-juridisch } & 0.34\end{array}$

HBO commerciële economie

MBO/LLW commercieel $\quad 0.77$

HAVOMWO bovenbouw $\quad 0.59$

MBO/LLW handel $\quad 0.54$

$\mathrm{HBO}$ technische bedrijfskunde $\quad 0.53$

MBO bestuurlijk-juridisch $\quad 0.53$

MAVO, onderbouw HAVONWO $\quad 0.53$

$\begin{array}{ll}\text { WO bedrijfskunde } & 0.51\end{array}$

VBO administratie $\quad 0.51$

HBO bestuurlijk-juridisch $\quad 0.50$

WO econom(etr)ie en accountancy $\quad 0.50$

HBO bedrijfseconomie $\quad 0.49$

MBO/LLW administratief $\quad 0.40$

HBO accountancy $\quad 0.36$

VBO verkoop en handel $\quad 0.35$

HBO werktuigbouwkunde $\quad 0.35$

HBO landbouw en milieukunde $\quad 0.34$

MBO/LLW secretarieel $\quad 0.30$

HBO technische bedrijfskunde

WO bedrijfskunde $\quad 0.80$

HBO werktuigbouwkunde $\quad 0.61$

HBO elektrotechniek en technische informatica $\quad 0.60$

WO werktuigbouwkunde $\quad 0.59$

WO elektrotechniek en technische informatica 0.58

$\mathrm{HBO}$ bedrijfsinformatica $\quad 0.58$

HBO commerciële economie $\quad 0.53$

WO landbouw en milieukunde $\quad 0.50$

WO informatica $\quad 0.49$

WO econom(etr)ie en accountancy $\quad 0.44$

HAVOMWO bovenbouw $\quad 0.42$

HBO landbouw en milieukunde $\quad 0.35$

HBO bedrijfseconomie $\quad 0.34$

$\mathrm{HBO}$ (weg-en water)bouwkunde $\quad 0.34$

HBO bestuurlijk-juridisch 0.33

WO wiskunde en natuurwetenschappen $\quad 0.32$

WO sociaal-cultureel 0.32

MBO/LLW werktuigbouwkunde $\quad 0.30$ 
Tabel 3.19 (vervolg)

Overzicht van opleidingstypen waarvan op de arbeidsmarkt (sterke) concurrentie wordt ondervonden

Opleidingstype concurrentie-index

MBOLLW commercieel

HBO bestuurlijk-juridisch

$\begin{array}{ll}\text { MBO bestuurlijk-juridisch } & 0.75\end{array}$

WO bestuurlijk $\quad 0.68$

MBO/LLW commercieel $\quad 0.65$

HAVOMWO bovenbouw $\quad 0.65$

VBO administratie $\quad 0.63$

MAVO, onderbouw HAVONWO $\quad 0.58$

WO econom(etr)ie en accountancy $\quad 0.57$

HBO bedrijfseconomie $\quad 0.56$

WO juridisch $\quad 0.55$

HBO accountancy $\quad 0.52$

MBO/LLW handel $\quad 0.51$

HBO commerciële economie $\quad 0.50$

MBO/LLW administratief $\quad 0.50$

HBO landbouw en milieukunde $\quad 0.43$

MBORLW secretarieel $\quad 0.41$

WO landbouw en milieukunde $\quad 0.40$

WO sociaal-cultureel $\quad 0.34$

HBO toerisme en recreatie $\quad 0.34$

HBO technische bedrijfskunde $\quad 0.33$

WO bedrijfskunde $\quad 0.33$

MBO toerisme en recreatie $\quad 0.33$

HBO sociaal-cultureel

MBO sociaal-cultureel

WO sociaal-cultureel $\quad 0.62$

HBO kunst

Wo kunst

HBO politie en defensie

MBO politie en defensie

wo letteren

HBO tolk en vertaler

WO theologisch

WO landbouw en milieukunde

HBO landbouw en milieukunde $\quad 0.61$

HBO technische bedriifskunde $\quad 0.50$

WO (weg-en water)bouwkunde $\quad 0.49$

$\begin{array}{ll}\text { WO werktuigbouwkunde } & 0.49\end{array}$ 
Tabel 3.19 (vervolg)

Overzicht van opleidingstypen waarvan op de arbeidsmarkt (sterke) concurrentie wordt ondervonden

\begin{tabular}{lc}
\hline Opleidingstype & concurrentie-ind \\
\hline & \\
WO bedrijfskunde & 0.41 \\
HBO bestuurlijk-juridisch & 0.40 \\
WO elektrotechniek en technische informatica & 0.37 \\
HBO werktuigbouwkunde & 0.35 \\
HBO (weg- en water)bouwkunde & 0.33 \\
WO sociaal-cultureel & 0.32 \\
HAVOMWO bovenbouw & 0.32 \\
WO informatica & 0.31 \\
HBO elektrotechniek en technische informatica & 0.31 \\
MBO bestuurlijk-juridisch & 0.31
\end{tabular}

WO wiskunde en natuurwetenschappen

WO elektrotechniek en technische informatica $\quad 0.32$

$\begin{array}{ll}\text { HBO bedrijfsinformatica } & 0.30\end{array}$

wo (weg-en water)bouwkunde

HBO (weg-en water)bouwkunde $\quad 0.50$

WO landbouw en milieukunde $\quad 0.49$

\section{WO werktuigbouwkunde}

HBO werktuigbouwkunde $\quad 0.72$

$\mathrm{HBO}$ technische bedrijfskunde $\quad 0.59$

WO bedrijfskunde $\quad 0.53$

WO elektrotechniek en technische informatica $\quad 0.51$

WO landbouw en milieukunde $\quad 0.49$

HBO elektrotechniek en technische informatica $\quad 0.43$

HBO bedrijfsinformatica $\quad 0.36$

HBO landbouw en milieukunde $\quad 0.34$

$\begin{array}{ll}\text { WO informatica } & 0.31\end{array}$

wo elektrotechniek en technische informatica

HBO elektrotechniek en technische informatica $\quad 0.87$

HBO bedrijfsinformatica $\quad 0.73$

$\begin{array}{ll}\text { WO informatica } & 0.69\end{array}$

HBO technische bedrijfskunde $\quad 0.58$

WO werktuigbouwkunde $\quad 0.51$

WO bedrijfskunde $\quad 0.42$

HBO werktuigbouwkunde $\quad 0.40$

WO landbouw en milieukunde $\quad 0.37$

WO wiskunde en natuurwetenschappen $\quad 0.32$

WO dier-, genees-en tandheelkunde

Wo farmacie 
Tabel 3.19 (vervolg)

Overzicht van opleidingstypen waarvan op de arbeidsmarkt (sterke) concurrentie wordt ondervonden

\section{WO econom(etr)ie en accountancy}

WO bestuurlijk

HBO accountancy

$\mathrm{HBO}$ bestuurlijk-juridisch

$\mathrm{HBO}$ bedrijfseconomie

0.56

WO bedrijfskunde

HBO commerciële economie

0.50

HBO technische bedrijfskunde

HAVONWO bovenbouw

0.37

MBO/LLW administratief

0.35

MBO bestuurlijk-juridisch

0.33

MBO/LLW commercieel

\section{WO bedrijfskunde}

HBO technische bedrijfskunde $\quad 0.80$

WO econom(etr)ie en accountancy $\quad 0.55$

WO werktuigbouwkunde $\quad 0.53$

HBO werktuigbouwkunde $\quad 0.51$

HBO commerciële economie $\quad 0.51$

WO elektrotechniek en technische informatica $\quad 0.42$

WO landbouw en milieukunde $\quad 0.41$

HBO bestuurlijk-juridisch $\quad 0.33$

HBO bedrijfseconomie $\quad 0.32$

0.32

HBO elektrotechniek en technische informatica 0.31

WO sociaal-cultureel $\quad 0.31$

WO informatica

0.95

HBO elektrotechniek en technische informatica 0.80

WO elektrotechniek en technische informatica $\quad 0.69$

HBO technische bedrijfskunde $\quad 0.49$

WO werktuigbouwkunde $\quad 0.31$

wo juridisch

HBO bestuurlijk-juridisch $\quad 0.55$

WO bestuurlijk $\quad 0.48$

MBO bestuurlijk-juridisch $\quad 0.33$

Wo bestuurlijk

WO econom(etr)ie en accountancy $\quad 0.72$

HBO bestuurlijk-juridisch $\quad 0.68$

HBO accountancy $\quad 0.54$

WO juridisch $\quad 0.48$

0.33 
Tabel 3.19 (vervolg)

Overzicht van opleidingstypen waarvan op de arbeidsmarkt (sterke) concurrentie wordt ondervonden

WO sociaal-cultureel

HBO sociaal-cultureel

0.62

MBO sociaal-culturee

0.42

HBO bestuurlijk-juridisch

0.34

HAVONWO bovenbouw

0.33

WO landbouw en milieukunde

0.32

HBO technische bedrijfskunde

0.32

WO bedrijfskunde

wo kunst

HBO kunst

Bron: ROA 
Tabel 3.20

Conjunctuurgevoeligheid per opleidingstype

Opleidingstype conjunctuurgevoeligheid typering

\section{BASISONDERWIJS}

Basisonderwijs

MAVO, VBO

MAVO, onderbouW HAVOMWO

VBO landbouw en natuurlijke omgeving

BO bouwtechniek

1,32

erg hoog

VBO installatietechniek

1,64

erg hoog

BO mechanische techniek

1,13

hoog

VBO motorvoertuigentechniek

1,05

hoog

VBO elektrotechniek

1,01

VBO grafische techniek

0,90

VBO consumptieve techniek

0,74

VBO textiel- en ledertechniek

VBO haven en vervoer

1,42

VBO administratie

VBO verkoop en handel

VBO verzorging

hoog

VBO bewaking

HAVONWO, MBORLW

HAVOMWO bovenbouw

MBO/LLW landbouw en natuurlijke omgeving

MBO technisch laboratorium

MBO/LLW bouwkunde

MBO/LLW weg- en waterbouwkunde

MBOLLW metaalkunde

MBO/LLW fijnmechanische techniek $\quad 0,97$

MBO/LLW werktuigbouwkunde $\quad 1,02$

MBO/LLW motorvoertuigentechniek $\quad 0,92$

MBOЛLW elektrotechniek $\quad 0,97$

MBO/LLW grafische techniek $\quad 0,86$

MBO/LLW consumptieve techniek $\quad 0,68$

MBO/LLW procestechniek $\quad 1,05$

MBORLW textiel- en ledertechniek $\quad 0,70$

MBO LLW haven en vervoer $\quad 0,89$

MBO/LLW verpleging en medische assistentie $\quad 0,43$

MBO/LLW medisch laboratorium $\quad 0,50$

MBO/LLW handel $\quad 0,69$

MBO/LLW administratief $\quad 0,70$

MBO toerisme en recreatie $\quad 0,63$

MBO/LLW commercieel $\quad 0,62$

MBOLLWW secretarieel

MBO bestuurlijk-juridisch

MBO sociaal-cultureel

0,61

0,63

0,51

MBO/LLW verzorging

MBO/LLW horeca en uiterlijke verzorging

0,51

0,45

erg laag

MBO politie en defensie

0,53

gemiddeld

laag

gemiddeld

erg hoog

hoog

hoog

hoog

hoog

gemiddeld

hoog

gemiddeld

gemiddeld

hoog

gemiddeld

gemiddeld

laag

laag

gemiddeld

gemiddeld

laag

laag

laag

laag

laag

laag

laag

laag 
Tabel 3.20 (vervolg)

Conjunctuurgevoeligheid per opleidingstype

\begin{tabular}{|c|c|c|}
\hline Opleidingstype & conjunctuurgevoeligheid & typering \\
\hline \multicolumn{3}{|l|}{ HBO } \\
\hline $\begin{array}{l}\text { HBO onderwijs } \\
\text { HBO tolk en vertaler } \\
\text { HBO landbouw en milieukunde } \\
\text { HBO technisch laboratorium } \\
\text { HBO (weg-en water)bouwkunde } \\
\text { HBO werktuigbouwkunde } \\
\text { HBO elektrotechniek en technische informatica } \\
\text { HBO haven en vervoer } \\
\text { HBO medisch laboratorium } \\
\text { HBO verpleging en paramedisch } \\
\text { HBO bedrijfseconomie } \\
\text { HBO accountancy } \\
\text { HBO bedrijfsinformatica } \\
\text { HBO toerisme en recreatie } \\
\text { HBO commerciële economie } \\
\text { HBO technische bedrijfskunde } \\
\text { HBO bestuurlijk-juridisch } \\
\text { HBO sociaal-cultureel } \\
\text { HBO kunst } \\
\text { HBO politie en defensie }\end{array}$ & $\begin{array}{l}0,50 \\
0,56 \\
0,78 \\
0,79 \\
0,88 \\
0,86 \\
1,31 \\
0,62 \\
0,53 \\
0,45 \\
0,77 \\
0,90 \\
1,16 \\
0,63 \\
0,69 \\
0,96 \\
0,60 \\
0,49 \\
0,71 \\
0,51\end{array}$ & $\begin{array}{l}\text { laag } \\
\text { laag } \\
\text { gemiddeld } \\
\text { gemiddeld } \\
\text { gemiddeld } \\
\text { gemiddeld } \\
\text { erg hoog } \\
\text { laag } \\
\text { laag } \\
\text { laag } \\
\text { gemiddeld } \\
\text { gemiddeld } \\
\text { erg hoog } \\
\text { laag } \\
\text { gemiddeld } \\
\text { hoog } \\
\text { laag } \\
\text { laag } \\
\text { gemiddeld } \\
\text { laag }\end{array}$ \\
\hline \multicolumn{3}{|l|}{ wo } \\
\hline $\begin{array}{l}\text { WO letteren } \\
\text { WO theologisch } \\
\text { WO landbouw en milieukunde } \\
\text { WO wiskunde en natuurwetenschappen } \\
\text { WO (weg- en water)bouwkunde } \\
\text { WO werktuigbouwkunde } \\
\text { WO elektrotechniek en technische informatica } \\
\text { WO dier-, genees- en tandheelkunde } \\
\text { WO farmacie } \\
\text { WO econom(etr)ie en accountancy } \\
\text { WO bedrijfskunde } \\
\text { WO informatica } \\
\text { WO juridisch } \\
\text { WO bestuurlijk } \\
\text { WO sociaal-cultureel } \\
\text { WO kunst }\end{array}$ & $\begin{array}{l}0,57 \\
0,14 \\
0,94 \\
0,94 \\
0,93 \\
1,01 \\
1,47 \\
0,51 \\
0,48 \\
0,91 \\
0,89 \\
1,26 \\
0,39 \\
0,73 \\
0,54 \\
0,49\end{array}$ & $\begin{array}{l}\text { laag } \\
\text { erg laag } \\
\text { hoog } \\
\text { hoog } \\
\text { gemiddeld } \\
\text { hoog } \\
\text { erg hoog } \\
\text { laag } \\
\text { laag } \\
\text { gemiddeld } \\
\text { gemiddeld } \\
\text { erg hoog } \\
\text { erg laag } \\
\text { gemiddeld } \\
\text { laag } \\
\text { laag }\end{array}$ \\
\hline
\end{tabular}

Bron: ROA 
Tabel 3.21

Percentage schoolverlaters met een intredewerkloosheid van 4 maanden of langer per opleidingsrichting, 1995

\begin{tabular}{lll}
\hline Opleidingstype en -richting & typering \\
\hline
\end{tabular}

MAVO, VBO

MAVO en onderbouw HAVOMWO

VBO land-en tuinbouw

VBO technisch

VBO bouwtechniek

VBO mechanische techniek

VBO motorvoertuigentechniek

VBO elektrotechniek

VBO grafische techniek

VBO consumptieve techniek

VBO textiel- en ledertechniek

VBO economisch-administratief

VBO administratie

VBO verkoop en handel

VBO verzorgend

VBO verzorging

VBO uiterijike verzorging

HAVONWO, MBO
11

8

12

WNO

MBO landbouw en natuurlijke omgeving

KMBO agrarisch

MBO plantenteelt

$M B O$ veehouderij

MBO levensmiddelentechnologie

MBO bloemschikken

MBO dierenverzorging

MBO groene ruimte

MBO technisch laboratorium

MBO chemisch laboratorium

MBO technisch

KMBO motorvoertuigentechniek

KMBO elektrotechniek

KMBO consumptieve techniek

MBO bouwkunde

MBO weg- en waterbouwkunde

MBO mechanische techniek

MBO werktuigbouwkunde

MBO motorvoertuigentechniek

MBO elektrotechniek

MBO textiel- en ledertechniek
3

3

12

8

9

20

3

$x^{2}$

7

2

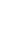

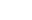

erg laag

erg laag

laag

laag

laag

laag

gemiddeld

laag

laag

laag

hoog

erg laag

hoog

erg laag

erg laag

hoog

erg laag

erg laag

laag

erg laag

gemiddeld

gemiddeld

gemiddeld

erg laag

laag

gemiddeld

gemiddeld

laag

erg laag

laag

erg laag

gemiddeld

laag 
Tabel 3.21 (vervolg)

Percentage schoolverlaters met een intredewerkloosheid van 4 maanden of langer per opleidingsrichting, 1995

\begin{tabular}{|c|c|c|}
\hline Opleidingstype en -richting & $\%$ & typering \\
\hline MBO haven en vervoer & 2 & erg laag \\
\hline \multicolumn{3}{|c|}{ MBO verpleging en medische assistentie } \\
\hline MBO verpl. en ziekenverzorging & 13 & gemiddeld \\
\hline MBO assistent gezondheidszorg & 18 & gemiddeld \\
\hline \multicolumn{3}{|l|}{ MBO economisch-administratief } \\
\hline KMBO detailhandel & 12 & laag \\
\hline KMBO administratie & 25 & hoog \\
\hline MBO handel & 14 & gemiddeld \\
\hline MBO administratie & 13 & gemiddeld \\
\hline MBO toerisme & 15 & gemidideld \\
\hline MBO commercieel & 15 & gemiddeld \\
\hline MBO secretarieel & 14 & gemiddeld \\
\hline MBO bestuurlijk & 4 & erg laag \\
\hline MBO sociale arbeid & 15 & gemiddeld \\
\hline \multicolumn{3}{|l|}{ MBO verzorgend } \\
\hline KMBO verzorging & 18 & gemiddeld \\
\hline MBO agogisch werk & 23 & hoog \\
\hline MBO verzorging & 8 & laag \\
\hline MBO mode en kleding & 8 & laag \\
\hline MBO activiteitenbegeleiding & 19 & gemiddeld \\
\hline \multicolumn{3}{|l|}{ MBO horeca en uiterlijke verzorging } \\
\hline MBO horeca & 8 & laag \\
\hline MBO facilitaire dienstverlening & 12 & laag \\
\hline MBO uiterlijke verzorging & 10 & laag \\
\hline \multicolumn{3}{|l|}{ HBO } \\
\hline \multicolumn{3}{|l|}{ HBO onderwijs } \\
\hline HBO basisonderwijzer & 17 & gemiddeld \\
\hline HBO leraar agrarisch & 2 & erg laag \\
\hline HBO leraar kunst/expressie & 26 & hoog \\
\hline HBO leraar voortgezet onderwijs & 16 & gemiddeld \\
\hline HBO tolk en vertaler & 27 & erg hoog \\
\hline HBO agrarisch & 22 & hoog \\
\hline HBO technisch laboratorium & 28 & erg hoog \\
\hline \multicolumn{3}{|l|}{ HBO technisch } \\
\hline HBO (weg-en water)bouwkunde & 12 & laag \\
\hline HBO werktuigbourwkunde & 16 & gemiddeld \\
\hline HBO elektrotechiek & 20 & hoog \\
\hline HBO haven en vervoer & 10 & laag \\
\hline
\end{tabular}


Tabel 3.21 (vervolg)

Percentage schoolverlaters met een intredewerkloosheid van 4 maanden of langer per opleidingsrichting, 1995

\begin{tabular}{lcl}
\hline Opleidingstype en -richting & $\%$ & typering \\
\hline HBO medisch analist & 26 & hoog \\
HBO verpleging en paramedisch & 6 & \\
HBO verpleegkunde & 15 & erg laag \\
HBO (fysio-)therapie & & gemiddeld \\
HBO economisch-administratief & 12 & \\
HBO bedrijfseconomie & 7 & laag \\
HBO accountancy & 12 & erg laag \\
HBO bedrijfsinformatica & 20 & laag \\
HBO toerisme & 16 & gemiddeld \\
HBO commerciële economie & 14 & gemiddeld \\
HBO technische bedrijfskunde & 17 & gemiddeld \\
HBO bestuurlijkjuridisch & & \\
HBO sociaal-cultureel & 20 & hoog \\
HBO welzijnswerk/sociaal & 19 & gemiddeld \\
HBO personeelswerk & 26 & hoog \\
HBO joumalistiek & 33 & erg hoog \\
HBO kunst & & \\
\hline BrOn: RUBSHBO-MonitorROA & &
\end{tabular}

Bron: RUBS/HBO-Monitor/ROA

- In procenten van de schoolverlaters die tot de beroepsbevolking behoren. 
Tabel 3.22

Percentage schoolveriaters dat als werkloos staat geregistreerd per opleidingsrichting, 1995

\begin{tabular}{lll}
\hline Opleidingstype en -richting & $\%$ & typering
\end{tabular}

MAVO, VBO

MAVO en onderbouW HAVONWO

VBO land- en tuinbouw

VBO technisch

VBO bouwtechniek

VBO mechanische techniek

VBO motorvoertuigentechniek

VBO elektrotechniek

VBO grafische techniek

VBO consumptieve techniek

VBO textiel- en ledertechniek

VBO economisch-administratief

VBO administratie

VBO verkoop en handel

VBO verzorgend

VBO verzorging

VBO uiterlijke verzorging

HAVONWO, MBO

HAVONWO bovenbouW

HAVO

WWO

MBO landbouw en natuurlijke omgeving

KMBO agrarisch

MBO plantenteelt

$M B O$ veehouderi]

MBO levensmiddelentechnologie

MBO bloemschikken

MBO dierenverzorging

MBO groene ruimte

MBO technisch laboratorium

MBO chemisch laboratorium

MBO technisch

KMBO motorvoertuigentechniek

KMBO elektrotechniek

KMBO consumptieve techniek

MBO bouwkunde

MBO weg- en waterbouwkunde

MBO mechanische techniek

MBO werktuigbouwkunde

MBO motorvoertuigentechniek

MBO elektrotechniek

MBO textiet- en ledertechniek
9

11

13

hoog

6

laag

erg laag

laag

hoog

gemiddeld

erg laag

hoog

gemiddeld

laag

gemiddeld

hoog

gemiddeld

erg laag

erg laag

erg laag

erg laag

hoog

erg laag

erg laag

laag

gemiddeld

gemiddeld

laag

erg laag

-

laag

gemiddeld

laag 
Tabel 3.22 (vervolg)

Percentage schoolveriaters dat als werkloos staat geregistreerd per opleidingsrichting, 1995

\begin{tabular}{|c|c|c|}
\hline Opleidingstype en -richting & $\%$ & typering \\
\hline MBO haven en vervoer & 8 & gemiddeld \\
\hline \multicolumn{3}{|c|}{ MBO verpleging en medische assistentie } \\
\hline MBO verpl. en ziekenverzorging & 1 & erg laag \\
\hline MBO assistent gezondheidszorg & 6 & laag \\
\hline \multicolumn{3}{|l|}{ MBO economisch-administratief } \\
\hline KMBO detailhandel & 13 & hoog \\
\hline KMBO administratie & 13 & hoog \\
\hline MBO handel & 7 & gemiddeld \\
\hline MBO administratie & 3 & erg laag \\
\hline MBO toerisme & 4 & erg laag \\
\hline MBO commercieel & 6 & laag \\
\hline MBO secretarieel & 4 & erg laag \\
\hline MBO bestuurlijk & . & erg hoog \\
\hline MBO sociale arbeid & 9 & gemiddeld \\
\hline \multicolumn{3}{|l|}{ MBO verzorgend } \\
\hline KMBO verzorging & 19 & erg hoog \\
\hline MBO agogisch werk & 10 & gemiddeld \\
\hline MBO verzorging & 3 & erg laag \\
\hline MBO mode en kleding & 13 & hoog \\
\hline MBO activiteitenbegeleiding & 10 & gemiddeld \\
\hline \multicolumn{3}{|l|}{ MBO horeca en uiterlijke verzorging } \\
\hline MBO horeca & · & $-\quad \ldots$ \\
\hline MBO facilitaire dienstverlening & 8 & gemiddeld \\
\hline MBO uiterijke verzorging & 5 & laag \\
\hline \multicolumn{3}{|l|}{ HBO } \\
\hline \multicolumn{3}{|l|}{ HBO onderwijs } \\
\hline HBO basisonderwijzer & 4 & erg laag \\
\hline HBO leraar agrarisch & 2 & erg laag \\
\hline HBO leraar kunst/expressie & 13 & hoog \\
\hline HBO leraar voortgezet onderwijs & 13 & hoog \\
\hline HBO tolk en vertaler & 13 & hoog \\
\hline HBO agrarisch & 11 & hoog \\
\hline HBO technisch laboratorium & 14 & hoog \\
\hline \multicolumn{3}{|l|}{ HBO technisch } \\
\hline HBO (weg- en water)bouwkunde & 3 & erg laag \\
\hline HBO werktuigbourwkunde & 6 & laag \\
\hline HBO elektrotechiek & 6 & laag \\
\hline HBO haven en vervoer & 3 & erg laag \\
\hline
\end{tabular}


Tabel 3.22 (vervolg)

Percentage schoolverlaters dat als werkloos staat geregistreerd per opleidingsrichting, 1995

\begin{tabular}{lll}
\hline Opleidingstype en -richting & $\%$ & typering \\
\hline HBO medisch analist & 4 & erg laag \\
HBO verpleging en paramedisch & & \\
HBO verpleegkunde & 2 & erg laag \\
HBO (fysio-)therapie & 7 & gemiddeld \\
HBO economisch-administratief & & erg laag \\
HBO bedrijfseconomie & 3 & erg laag \\
HBO accountancy & 3 & - \\
HBO bedrijfsinformatica & gemiddeld \\
HBO toerisme & 9 & $\begin{array}{l}\text { laag } \\
\text { HBO commerciële economie }\end{array}$ \\
HBO technische bedrijfskunde & 6 & laag \\
HBO bestuurlijkjuridisch & 5 & gemiddeld \\
HBO sociaal-cultureel & 8 & \\
HBO welzijnswerk/sociaal & & gemiddeld \\
HBO personeelswerk & gemiddeld \\
HBO journalistiek & 7 & laag \\
HBO kunst & 12 & hoog \\
\hline
\end{tabular}

Bron: RUBS/HBO-Monitor/ROA

In procenten van de schoolverlaters die tot de beroepsbevolking behoren. 
Tabel 3.23

Percentage onderbenutting per opleidingstype, 1995

\begin{tabular}{lll}
\hline Opleidingstype & $\%$ & typering \\
\hline
\end{tabular}

\section{BASISONDERWISS}

Basisonderwijs

MAVO, VBO

MAVO, onderbouW HAVOMWO

gemiddeld

VBO landbouw en natuurlijke omgeving

gemiddeld

VBO bouwtechniek

gemiddeld

VBO instaliatietechniek

gemiddeld

VBO mechanische techniek

gemiddeld

VBO motorvoertuigentechniek

gemiddeld

VBO elektrotechniek

gemiddeld

VBO grafische techniek

VBO consumptieve techniek

laag

VBO textiel- en ledertechniek

hoog

hoog

erg hoog

VBO administratie

VBO verkoop en handel

gemiddeld

hoog

VBO verzorging

VBO bewaking

hoog

erg hoog

HAVONWO, MBORLW

HAVONWO bovenbouw

MBO/LLW landbouw en natuurlijke omgeving

MBO technisch laboratorium

MBO/LLWW bouwkunde

MBO/LLW weg- en waterbouwkunde

MBO/LLW metaalkunde

MBO/LLW fijnmechanische techniek

MBO/LLW werktuigbouwkunde

MBO/LLW motorvoertuigentechniek

MBO/LLW elektrotechniek

MBO/LLW grafische techniek

MBO/LLW consumptieve techniek

MBO/LLW procestechniek

MBO/LLW textiel- en ledertechniek

MBO/LLW haven en vervoer

MBO/LLW verpleging en medische assistentie

MBO/LLW medisch laboratorium

MBO/LLW handel

MBO/LLW administratief

MBO toerisme en recreatie

MBO/LLW commercieel

MBO/LLW secretarieel

MBO bestuurlijk-juridisch

MBO sociaal-cultureel

MBO/LLW verzorging

MBO/LLW horeca en uiterlijke verzorging

MBO politie en defensie

gemiddeld

gemiddeld

laag

gemiddeld

gemiddeld

hoog

gemiddeld

gemiddeld

gemiddeld

laag

hoog

hoog

erg hoog

erg hoog

hoog

laag

erg laag

gemiddeld

laag

hoog

gemiddeld

gemiddeld

gemiddeld

gemiddeld

hoog

gemiddeld

hoog 
Tabel 3.23 (vervolg)

Percentage onderbenutting per opleidingstype, 1995

\begin{tabular}{lll}
\hline Opleidingstype & $\%$ & typering \\
\hline
\end{tabular}

HBO

HBO onderwijs

HBO tolk en vertaler

HBO landbouw en milieukunde

laag

$\mathrm{HBO}$ technisch laboratorium

$\mathrm{HBO}$ (weg-en water)bouwkunde

$\mathrm{HBO}$ werktuigbouwkunde

HBO elektrotechniek en technische informatica

HBO haven en vervoer

HBO medisch laboratorium

$H B O$ verpleging en paramedisch

$\mathrm{HBO}$ bedrijfseconomie

HBO accountancy

$\mathrm{HBO}$ bedrijfsinformatica

$\mathrm{HBO}$ toerisme en recreatie

HBO commerciële economie

HBO technische bedrijfskunde

HBO bestuurlijk-juridisch

HBO sociaal-cultureel

HBO kunst

HBO politie en defensie

$\begin{array}{ll}14 & \text { laag } \\ 55 & \text { hoog } \\ 30 & \text { gemiddeld } \\ 15 & \text { laag } \\ 14 & \text { laag } \\ 16 & \text { laag } \\ 15 & \text { laag } \\ 41 & \text { gemiddeld } \\ 10 & \text { erg laag } \\ 11 & \text { laag } \\ 53 & \text { hoog } \\ 45 & \text { gemiddeld } \\ 11 & \text { laag } \\ 74 & \text { erg hoog } \\ 49 & \text { gemiddeld } \\ 24 & \text { laag } \\ 48 & \text { gemiddeld } \\ 26 & \text { gemiddeld } \\ 20 & \text { laag } \\ 52 & \text { hoog }\end{array}$

wo

WO letteren

WO theologisch

WO landbouw en milieukunde

WO wiskunde en natuurwetenschappen

WO (weg- en water)bouwkunde

WO werktuigbouwkunde

WO elektrotechniek en technische informatica

WO dier-, genees- en tandheelkunde

WO farmacie

WO econom(etr)ie en accountancy

WO bedrijfskunde

WO informatica

WO juridisch

WO bestuurlijk

Wo sociaal-cultureel

wo kunst

$\begin{aligned} 18 & \text { laag } \\ 23 & \text { laag } \\ 23 & \text { laag } \\ 14 & \text { laag } \\ 17 & \text { laag } \\ 15 & \text { laag } \\ 11 & \text { laag } \\ 8 & \text { erg laag } \\ 13 & \text { laag } \\ 27 & \text { gemiddeld } \\ 26 & \text { gemiddeld } \\ 20 & \text { laag } \\ 28 & \text { gemiddeld } \\ 18 & \text { laag } \\ 33 & \text { gemiddeld } \\ 24 & \text { laag }\end{aligned}$

Bron: ROA

Bepaald op basis van het functieniveau van de beroepsgroep. 
Tabel 3.24

Onderbenutting van werkzame schoolverlaters per opleidingsrichting, 1995

\begin{tabular}{|c|c|c|}
\hline Opleidingstype en -richting & $\%$ & typering \\
\hline \multicolumn{3}{|l|}{ MAVO, VBO } \\
\hline MAVO en onderbouw HAVOMWO & 21 & gemiddeld \\
\hline VBO land-en tuinbouw & 34 & gemiddeld \\
\hline \multicolumn{3}{|l|}{ VBO technisch } \\
\hline VBO bouwtechniek & 12 & laag \\
\hline VBO mechanische techniek & 12 & laag \\
\hline VBO motorvoertuigentechniek & 6 & erg laag \\
\hline VBO elektrotechniek & 30 & gemiddeld \\
\hline VBO grafische techniek & & gemiddeld \\
\hline VBO consumptieve techniek & 14 & laag \\
\hline VBO textiel- en ledertechniek & - & laag \\
\hline \multicolumn{3}{|l|}{ VBO economisch-administratief } \\
\hline VBO administratie & & laag \\
\hline VBO verkoop en handel & 21 & gemiddeld \\
\hline \multicolumn{3}{|l|}{ VBO verzorgend } \\
\hline VBO verzorging & 18 & gemiddeld \\
\hline VBO uiterlijke verzorging & · & erg laag \\
\hline \multicolumn{3}{|l|}{ HAVOMWO, MBO } \\
\hline \multicolumn{3}{|l|}{ HAVOMWO bovenbouw } \\
\hline HAVO & 62 & erg hoog \\
\hline wo & 55 & hoog \\
\hline \multicolumn{3}{|c|}{ MBO landbouw en natuurlijke omgeving } \\
\hline KMBO agrarisch & 73 & erg hoog \\
\hline MBO plantenteelt & 48 & hoog \\
\hline MBO veehouderij & 54 & hoog \\
\hline MBO levensmiddelentechnologie & 41 & hoog \\
\hline MBO bloemschikken & 46 & hoog \\
\hline MBO dierenverzorging & 49 & hoog \\
\hline MBO groene ruimte & 36 & hoog \\
\hline \multicolumn{3}{|l|}{ MBO technisch laboratorium } \\
\hline MBO chemisch laboratorium & 36 & hoog \\
\hline \multicolumn{3}{|l|}{ MBO technisch } \\
\hline KMBO motorvoertuigentechniek & 15 & laag \\
\hline KMBO elektrotechniek & 31 & gemiddeld \\
\hline KMBO consumptieve techniek & 22 & gemiddeld \\
\hline MBO bouwkunde & 24 & gemiddeld \\
\hline MBO weg- en waterbouwkunde & & hoog \\
\hline MBO mechanische techniek & 32 & gemiddeld \\
\hline MBO werktuigbouwkunde & 41 & hoog \\
\hline MBO motorvoertuigentechniek & 30 & gemiddeld \\
\hline MBO elektrotechniek & 36 & hoog \\
\hline MBO textiel- en ledertechniek & 59 & erg hoog \\
\hline
\end{tabular}


Tabel 3.24 (vervolg)

Onderbenutting van werkzame schoolverlaters per opleidingsrichting, 1995

\begin{tabular}{|c|c|c|}
\hline Opleidingstype en -richting & $\%$ & typering \\
\hline MBO haven en vervoer & . & hoog \\
\hline \multicolumn{3}{|c|}{ MBO verpleging en medische assistentie } \\
\hline MBO verpl. en ziekenverzorging & 43 & hoog \\
\hline MBO assistent gezondheidszorg & 36 & hoog \\
\hline \multicolumn{3}{|l|}{ MBO economisch-administratief } \\
\hline KMBO detailhandel & 71 & erg hoog \\
\hline KMBO administratie & 53 & hoog \\
\hline MBO handel & 43 & hoog \\
\hline MBO administratie & 24 & gemiddeld \\
\hline MBO toerisme & 16 & laag \\
\hline MBO commercieel & 19 & gemiddeld \\
\hline MBO secretarieel & 17 & gemiddeld \\
\hline MBO bestuurlijk & . & gemiddeld \\
\hline MBO sociale arbeid & 46 & hoog \\
\hline \multicolumn{3}{|l|}{$M B O$ verzorgend } \\
\hline KMBO verzorging & 65 & erg hoog \\
\hline MBO agogisch werk & 40 & hoog \\
\hline MBO verzorging & 46 & hoog \\
\hline MBO mode en kleding & 56 & hoog \\
\hline MBO activiteitenbegeleiding & 31 & gemiddeld \\
\hline \multicolumn{3}{|l|}{ MBO horeca en uiterlijke verzorging } \\
\hline MBO horeca & 21 & gemiddeld \\
\hline MBO facilitaire dienstvertening & 77 & erg hoog \\
\hline MBO uiterlijke verzorging & 66 & erg hoog \\
\hline \multicolumn{3}{|l|}{ HBO } \\
\hline \multicolumn{3}{|l|}{ HBO onderwijs } \\
\hline HBO basisonderwijzer & 6 & erg laag \\
\hline $\mathrm{HBO}$ leraar agrarisch & 20 & gemiddeld \\
\hline HBO leraar kunst/expressie & 24 & gemiddeld \\
\hline HBO leraar voortgezet onderwijs & 26 & gemiddeld \\
\hline HBO tolk en vertaler & 33 & gemiddeld \\
\hline HBO agrarisch & 31 & gemiddeld \\
\hline HBO technisch laboratorium & 24 & gemiddeld \\
\hline \multicolumn{3}{|l|}{ HBO technisch } \\
\hline HBO (weg- en water)bouwkunde & 13 & laag \\
\hline HBO werktuigbouwkunde & 15 & laag \\
\hline HBO elektrotechiek & 12 & laag \\
\hline HBO haven en vervoer & 32 & gemiddeld \\
\hline
\end{tabular}


Tabel 3.24 (vervolg)

Onderbenutting van werkzame schoolverlaters per opleidingsrichting, 1995

\begin{tabular}{lrl}
\hline Opleidingstype en -richting & $\%$ & typering \\
\hline HBO medisch analist & 14 & laag \\
HBO verpleging en paramedisch & & \\
HBO verpleegkunde & 22 & gemiddeld \\
HBO (fysio-)therapie & 9 & erg laag \\
HBO economisch-administratief & & \\
HBO bedrijfseconomie & 21 & gemiddeld \\
HBO accountancy & 13 & laag \\
HBO bedrijfsinformatica & 9 & erg laag \\
HBO toerisme & 55 & geog \\
HBO commerciële economie & 29 & $\begin{array}{l}\text { gemiddeld } \\
\text { HBO technische bedrijskunde }\end{array}$ \\
HBO bestuurlijkjuridisch & 19 & $\begin{array}{l}\text { gemiddeld } \\
\text { HBO sociaal-cultureel }\end{array}$ \\
HBO welzijnswerk/sociaal & & \\
HBO personeelswerk & & hoog \\
HBO journalistiek & 45 & gemiddeld \\
HBO kunst & 26 & gemiddeld \\
\end{tabular}

Bron: RUBS/HBO-Monitor/ROA

- Bepaald op basis van het opleidingsniveau dat volgens de schoolverlater vereist is voor de door hen uitgeoefende functie. 
Tabel 3.25

Percentage werkzame schoolverlaters met een functie in de eigen vakrichting per opleidingsrichting, 1995

\begin{tabular}{lll}
\hline Opleidingstype en -richting & $\%$ & typering \\
\hline
\end{tabular}

MAVO, VBO

MAVO en onderbouW HAVOMWO

VBO land-en tuinbouw

VBO technisch

VBO bouwtechniek

VBO mechanische techniek

VBO motorvoertuigentechniek

VBO elektrotechniek

VBO grafische techniek

VBO consumptieve techniek

VBO textiel- en ledertechniek

VBO economisch-administratief

VBO administratie

VBO verkoop en handel

VBO verzorgend

VBO verzorging

VBO uiterlijke verzorging

HAVONWO, MBO

HAVONWO bovenbouW

HAVO

WWO

MBO landbouw en natuurlijke omgeving

KMBO agrarisch

MBO plantenteelt

$M B O$ veehouderij

MBO levensmiddelentechnologie

MBO bloemschikken

$M B O$ dierenverzorging

MBO groene ruimte

MBO technisch laboratorium

MBO chemisch laboratorium

MBO technisch

KMBO motorvoertuigentechniek

KMBO elektrotechniek

KMBO consumptieve techniek

MBO bouwkunde

MBO weg- en waterbouwkunde

MBO mechanische techniek

MBO werktuigbouwkunde

MBO motorvoertuigentechniek

MBO elektrotechniek

MBO textiel- en ledertechniek
3

27

erg laag

laag

gemiddeld

laag

gemiddeld

laag

laag

gemiddeld

erg laag

erg laag

erg laag

erg laag

erg laag

erg laag

erg laag

10

laag

gemiddeld

laag

gemiddeld

gemiddeld

gemiddeld

gemiddeld

71

gemiddeld

hoog

gemiddeld

gemiddeld

hoog

gemiddeld

gemiddeld

gemiddeld

gemiddeld

gemiddeld

laag 
Tabel 3.25 (vervolg)

Percentage werkzame schoolverlaters met een functie in de eigen vakrichting per opleidingsrichting, 1995

\begin{tabular}{|c|c|c|}
\hline Opleidingstype en -richting & $\%$ & typering \\
\hline MBO haven en vervoer & 58 & gemiddeld \\
\hline $\begin{array}{l}\text { MBO verpleging en medische assist } \\
\text { MBO verpl. en ziekenverzorging } \\
\text { MBO assistent gezondheidszorg }\end{array}$ & $\begin{array}{l}63 \\
77\end{array}$ & $\begin{array}{l}\text { gemiddeld } \\
\text { hoog }\end{array}$ \\
\hline $\begin{array}{l}\text { MBO economisch-administratief } \\
\text { KMBO detailhandel } \\
\text { KMBO administratie } \\
\text { MBO handel } \\
\text { MBO administratie } \\
\text { MBO toerisme } \\
\text { MBO commercieel } \\
\text { MBO secretarieel }\end{array}$ & $\begin{array}{l}19 \\
26 \\
24 \\
51 \\
48 \\
25 \\
49\end{array}$ & $\begin{array}{l}\text { erg laag } \\
\text { erg laag } \\
\text { erg laag } \\
\text { gemiddeld } \\
\text { gemiddeld } \\
\text { erg laag } \\
\text { gemiddeld }\end{array}$ \\
\hline MBO bestuurlijk & . & erg laag \\
\hline MBO sociale arbeid & 30 & laag \\
\hline $\begin{array}{l}\text { MBO verzorgend } \\
\text { KMBO verzorging } \\
\text { MBO agogisch werk } \\
\text { MBO verzorging } \\
\text { MBO mode en kleding } \\
\text { MBO activiteitenbegeleiding }\end{array}$ & $\begin{array}{l}30 \\
55 \\
66 \\
29 \\
69\end{array}$ & $\begin{array}{l}\text { laag } \\
\text { gemiddeld } \\
\text { gemiddeld } \\
\text { laag } \\
\text { gemiddeld }\end{array}$ \\
\hline $\begin{array}{l}\text { MBO horeca en uiterlijke verzorging } \\
\text { MBO horeca } \\
\text { MBO facilitaire dienstverlening } \\
\text { MBO uiterlijke verzorging }\end{array}$ & $\begin{array}{l}57 \\
33 \\
65\end{array}$ & $\begin{array}{l}\text { gemiddeld } \\
\text { laag } \\
\text { gemiddeld }\end{array}$ \\
\hline HBO & & \\
\hline $\begin{array}{l}\text { HBO onderwijs } \\
\text { HBO basisonderwijzer } \\
\text { HBO leraar agrarisch } \\
\text { HBO leraar kunst/expressie } \\
\text { HBO leraar voortgezet onderwijs }\end{array}$ & $\begin{array}{l}92 \\
81 \\
77 \\
68\end{array}$ & $\begin{array}{l}\text { erg hoog } \\
\text { hoog } \\
\text { hoog } \\
\text { gemiddeld }\end{array}$ \\
\hline HBO tolk en vertaler & 62 & gemiddeld \\
\hline HBO agrarisch & 62 & gemiddeld \\
\hline HBO technisch laboratorium & 78 & hoog \\
\hline $\begin{array}{l}\text { HBO technisch } \\
\text { HBO (weg- en water)bouwkunde } \\
\text { HBO werktuigbouwkunde } \\
\text { HBO elektrotechiek }\end{array}$ & $\begin{array}{l}90 \\
84 \\
86\end{array}$ & $\begin{array}{l}\text { erg hoog } \\
\text { hoog } \\
\text { hoog }\end{array}$ \\
\hline HBO haven en vervoer & 86 & hoog \\
\hline
\end{tabular}


Tabel 3.25 (vervolg)

Percentage werkzame schoolverlaters met een functie in de eigen vakrichting per opleidingsrichting, 1995

\begin{tabular}{lll}
\hline Opleidingstype en -richting & $\%$ & typering \\
\hline HBO medisch analist & 87 & hoog \\
HBO verpleging en paramedisch & & \\
HBO verpleegkunde & 96 & erg hoog \\
HBO (fysio-)therapie & 90 & erg hoog \\
HBO economisch-administratief & & \\
HBO bedrijfseconomie & 78 & hoog \\
HBO accountancy & 96 & erg hoog \\
HBO bedrijfsinformatica & 85 & hoog \\
HBO toerisme & 47 & gemiddeld \\
HBO commerciële economie & 61 & gemiddeld \\
HBO technische bedrijfskunde & 67 & hoog \\
HBO bestuurlijkjuridisch & & \\
HBO sociaal-cultureel & & hoog \\
HBO welzijnswerk/sociaal & 80 & gemiddeld \\
HBO personeelswerk & 67 & hoog \\
HBO journalistiek & 78 & hoog \\
HBO kunst & 74 &
\end{tabular}

Bron: RUBS/HBO-Monitor/ROA 
Tabel 3.26

Verwachte instroom van schoolverlaters per opleidingstype, 1995-2000

Opleidingstype aantal totaal gemiddeld typering

$\%$ jaarlijks \%

\section{BASISONDERWIJS}

Basisonderwijs

9

1,8

laag

MAVO, VBO

MAVO, onderbouW HAVOMWO

24.500

VBO landbouw en natuurlijke omgeving

6.600

14.200

1.500

VBO installatietechniek

14.800

VBO mechanische techniek

7.100
1.300

VBO motorvoertuigentechniek

VBO elektrotechniek

1.100

VBO grafische techniek

1.100
5.400

5.500
2.200

9.000

VBO haven en vervoer

5.000

VBO verkoop en handel

13.900

VBO verzorging

6.000

$\begin{array}{rr}6 & 1,2 \\ 9 & 1,7 \\ 10 & 2,0 \\ 16 & 3,1 \\ 11 & 2,1 \\ 14 & 2,7 \\ 2 & 0,4 \\ 15 & 2,8 \\ 26 & 4,8 \\ 23 & 4,3 \\ 6 & 1,2 \\ 15 & 2,7 \\ 16 & 3,1 \\ 7 & 1,3 \\ 58 & 9,6\end{array}$

laag

laag

laag

gemiddeld

laag

laag

erg laag

gemiddeld

gemiddeld

gemiddeld

laag

gemiddeld

gemiddeld

laag

VBO bewaking

erg hoog

\section{HAVONWO, MBO/LLW}

HAVONWO bovenbouw

87.500

23.000

3.700

MBO technisch laboratorium

MBO/LWW bouwkunde

MBO/LLW weg-en waterbouwkunde

MBORLW metaalkunde

MBO/LLW fijnmechanische techniek

MBO/LLW werktuigbouwkunde

MBO/LLW motorvoertuigentechniek

MBO/LLW elektrotechniek

MBO/LLW grafische techniek

MBO/LLW consumptieve techniek

MBO/LLW procestechniek

MBO/LWW textiel- en ledertechniek

MBO/LLW haven en vervoer

MBO/LLW verpleging en medische assistentie

MBO/LLW medisch laboratorium

MBO/LLW handel

MBO/LLW administratief

MBO toerisme en recreatie

MBO/LLW commercieel

MBO/LLW secretarieel

MBO bestuurlijk-juridisch

MBO sociaal-cultureel

MBO/LLW verzorging

MBO/LLW horeca en uiterlijke verzorging

MBO politie en defensie
27.600

5.000

12.000

1.700

18.400

20.600

29.000

5.900

7.900

1.900

6.400

8.500

44.800

3.700

89.500

26.800

4.900

8.500

20.800

1.800

18.900

62.700

8.500

17.300

28
17
27
17
23
21
11
20
34
20
16
19
11
18
18
25
13
28
29
32
24
22
4
34
29
14
22

5,1

3,1

4,9

3,1

4,3

3,8

2,1

3,8

6,1

3,7

3,0

3,5

2,2

3,3

3,4

4,5

2,4

5,0

5,2

5,7

4,4

4,0

0,7

6,0

5,0

5,2
2,6

4,0 gemiddeld

gemiddeld gemiddeld gemiddeld gemiddeld gemiddeld

laag

gemiddeld

hoog

gemiddeld

gemidideld

gemiddeld

laag

gemiddeld

gemiddeld

gemiddeld

laag

gemiddeld

hoog

hoog

gemiddeld

gemiddeld

erg laag

hoog

hoog

laag

gemiddeld 
Tabel 3.26 (vervolg)

Verwachte instroom van schoolverlaters per opleidingstype, 1995-2000

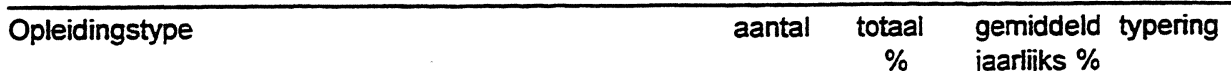

$\%$ jaarlijks \%

HBO

HBO onderwijs

$\begin{array}{llll}39.900 & 15 & 2,9 & \text { gemiddeld }\end{array}$

$H B O$ tolk en vertaler

$1.400 \quad 16 \quad 3,0$

$\mathrm{HBO}$ landbouw en milieukunde

$6.900 \quad 35 \quad 6,2$

HBO technisch laboratorium

$4.700 \quad 17 \quad 3,2$

HBO (weg-en water)bouwkunde

4.300

HBO werktuigbouwkunde

9.800

HBO elektrotechniek en technische informatica

13.700

HBO haven en vervoer

1.300

HBO medisch laboratorium

2.600

$\mathrm{HBO}$ verpleging en paramedisch

20.100

$H B O$ bedrijfseconomie

9.200

HBO accountancy

2.500

HBO bedrijfsinformatica

HBO toerisme en recreatie

4.900

1.700

HBO commerciële economie

HBO technische bedrijfskunde

12.300

6.500

4.300

(ecturlijk-juridisch

31.400

HBO sociaal-cultureel

HBO kunst

HBO politie en defensie

7.200

2.200

$12 \quad 2,2$

hoog

hoog

laag

laag

gemiddeld

erg hoog

laag

gemiddeld

gemiddeld

erg hoog

erg hoog

gemiddeld

gemiddeld

gemiddeld

wo

wo letteren

WO theologisch

WO landbouw en milieukunde

WO wiskunde en natuurwetenschappen

WO (weg-en water)bouwkunde

WO werktuigbouwkunde

WO elektrotechniek en technische informatica

WO dier-, genees- en tandheelkunde

WO farmacie

WO econom(etr)ie en accountancy

Wo bedrijfskunde

WO informatica

15.400

$600 \quad 12$

3.600

8.700

2.400

4.100

4.800

7.700

1.300

17.200

5.700

1.800

18.800

2.600

wO bestuurlijk

26.500

WO sociaal-cultureel

4.200

36
12
29
21
13
48
35
15
29
39
57
43
40
25
33
48

6,3

hoog

laag

hoog

gemiddeld

laag

erg hoog

hoog

gemiddeld

hoog

erg hoog

erg hoog

erg hoog

erg hoog

gemiddeld

wo kunst

Bron: ROA 
Tabel 3.27

Verwachte uitbreidingsvraag per opleidingstype, 1995-2000

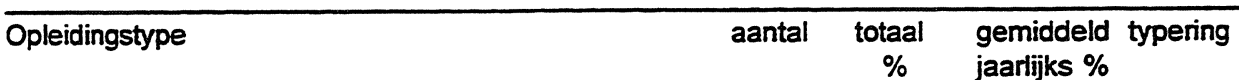

\section{BASISONDERWIS}

Basisonderwijs

$-66.300$

$-13$

$-2,8$

erg laag

MAVO, VBO

MAVO, onderbouw HAVOMWO

$\begin{array}{rrrl}-18.400 & -5 & -0,9 & \text { laag } \\ -7.100 & -9 & -1,9 & \text { erg laag } \\ -8.300 & -6 & -1,2 & \text { laag } \\ -500 & -6 & -1,1 & \text { laag } \\ -7.800 & -6 & -1,2 & \text { laag } \\ -2.700 & -5 & -1,1 & \text { laag } \\ -2.900 & -5 & -1,0 & \text { laag } \\ -200 & -4 & -0,7 & \text { laag } \\ -700 & -4 & -0,7 & \text { laag } \\ -1.100 & -5 & -0,9 & \text { laag } \\ -900 & -3 & -0,5 & \text { laag } \\ -3.800 & -6 & -1,3 & \text { laag } \\ -500 & -2 & -0,3 & \text { laag } \\ -6.400 & -3 & -0,6 & \text { laag } \\ 3.200 & 31 & 5,5 & \text { erg hoog }\end{array}$

VBO landbouw en natuurlijke omgeving

VBO bouwtechniek

VBO installatietechniek

VBO mechanische techniek

VBO motorvoertuigentechniek

VBO elektrotechniek

VBO grafische techniek

VBO consumptieve techniek

VBO textiel- en ledertechniek

VBO haven en vervoer

VBO administratie

VBO verkoop en handel

VBO verzorging

VBO bewaking

3.200

$\begin{array}{rrrl}20.700 & 7 & 1,3 & \text { gemiddeld } \\ -2.100 & -2 & -0,3 & \text { laag } \\ 1.200 & 9 & 1,7 & \text { gemiddeld } \\ 5.200 & 3 & 0,6 & \text { laag } \\ 1.200 & 6 & 1,1 & \text { gemiddeld } \\ 2.300 & 4 & 0,8 & \text { gemiddeld } \\ 900 & 6 & 1,2 & \text { gemiddeld } \\ 5.000 & 6 & 1,1 & \text { gemiddeld } \\ 2.100 & 3 & 0,7 & \text { laag } \\ 8.700 & 6 & 1,2 & \text { gemiddeld } \\ 2.200 & 6 & 1,2 & \text { gemiddeld } \\ 2.000 & 5 & 1,0 & \text { gemiddeld } \\ 900 & 5 & 1,0 & \text { gemiddeld } \\ 1.600 & 4 & 0,9 & \text { gemiddeld } \\ 2.600 & 6 & 1,1 & \text { gemiddeld } \\ 16.400 & 9 & 1,7 & \text { gemiddeld } \\ 2.900 & 10 & 2,0 & \text { gemiddeld } \\ 22.100 & 7 & 1,3 & \text { gemiddeld } \\ 2.900 & 3 & 0,6 & \text { laag } \\ 300 & 2 & 0,4 & \text { laag } \\ 2.100 & 6 & 1,2 & \text { gemiddeld } \\ 700 & 1 & 0,1 & \text { laag } \\ -400 & -1 & -0,2 & \text { laag } \\ 800 & 2 & 0,3 & \text { laag } \\ 9.100 & 4 & 0,8 & \text { gemiddeld } \\ 1.800 & 3 & 0,6 & \text { laag } \\ 13.500 & 17 & 3,1 & \text { hoog }\end{array}$


Tabel 3.27 (vervolg)

Verwachte uitbreidingsvraag per opleidingstype, 1995-2000

\begin{tabular}{|c|c|c|c|}
\hline Opleidingstype & aantal & $\begin{array}{c}\text { totaal } \\
\%\end{array}$ & $\begin{array}{l}\text { gemiddeld typering } \\
\text { jaarlijks \% }\end{array}$ \\
\hline
\end{tabular}

HBO

\begin{tabular}{|c|c|c|c|c|}
\hline & & & & \\
\hline HBO onderwijs & 18.500 & $\begin{array}{l}7 \\
9\end{array}$ & 1,4 & $\begin{array}{l}\text { gemiddeld } \\
\text { gemidideld }\end{array}$ \\
\hline $\begin{array}{l}\text { HBO tolk en vertaler } \\
\text { HBO landbouw en milieukunde }\end{array}$ & $\begin{array}{r}700 \\
2.700\end{array}$ & $\begin{array}{r}9 \\
14\end{array}$ & 2,7 & hoog \\
\hline $\begin{array}{l}\text { HBO landbouw en milieukunde } \\
\text { HBO technisch laboratorium }\end{array}$ & 6.000 & 22 & 4,0 & hoog \\
\hline HBO (weg- en water)bouwkunde & 5.300 & 15 & 2,7 & hoog \\
\hline HBO werktuigbouwkunde & 5.100 & 17 & 3,2 & hoog \\
\hline HBO elektrotechniek en technische informatica & 11.200 & 27 & 4,8 & erg hoog \\
\hline HBO haven en vervoer & 4.300 & 15 & 2,9 & hoog \\
\hline HBO medisch laboratorium & 3.400 & 16 & 2,9 & hoog \\
\hline HBO verpleging en paramedisch & 14.400 & 17 & 3,2 & hoog \\
\hline HBO bedrijfseconomie & 3.900 & 18 & 3,3 & hoog \\
\hline HBO accountancy & 7.000 & 25 & 4,5 & erg hoog \\
\hline HBO bedrijfsinformatica & 10.400 & 36 & 6,3 & erg hoog \\
\hline HBO toerisme en recreatie & 500 & 7 & 1,4 & gemiddeld \\
\hline HBO commerciële economie & 3.800 & 19 & 3,5 & hoog \\
\hline HBO technische bedrijfskunde & 2.800 & 22 & 4,0 & hoog \\
\hline HBO bestuurlijk-juridisch & 1.900 & 7 & 1,4 & gemiddeld \\
\hline HBO sociaal-cultureel & 14.100 & 12 & 2,3 & gemiddeld \\
\hline HBO kunst & 7.300 & 15 & 2,9 & hoog \\
\hline HBO politie en defensie & 200 & 2 & 0,5 & laag \\
\hline wo & & & & \\
\hline WO letteren & 7.000 & 17 & 3,1 & hoog \\
\hline WO theologisch & 700 & 13 & 2,5 & gemiddeld \\
\hline WO landbouw en milieukunde & 2.100 & 17 & 3,2 & hoog \\
\hline WO wiskunde en natuurwetenschappen & 9.400 & 22 & 4,1 & hoog \\
\hline WO (weg- en water)bouwkunde & 3.700 & 20 & 3,7 & hoog \\
\hline WO werktuigbouwkunde & 1.900 & 22 & 4,0 & hoog \\
\hline WO elektrotechniek en technische informatica & 4.200 & 31 & 5,5 & erg hoog \\
\hline WO dier-, genees- en tandheelkunde & 8.800 & 16 & 3,1 & hoog \\
\hline WO farmacie & 700 & 15 & 2,8 & hoog \\
\hline WO econom(etr)ie en accountancy & 14.900 & 34 & 6,0 & erg hoog \\
\hline WO bedrijfskunde & 3.200 & 32 & 5,7 & erg hoog \\
\hline WO informatica & 1.500 & 34 & 6,1 & erg hoog \\
\hline WO juridisch & 4.000 & 8 & 1,6 & gemiddeld \\
\hline WO bestuurlijk & 2.400 & 24 & 4,4 & erg hoog \\
\hline WO sociaal-cultureel & 14.800 & 18 & 3,4 & hoog \\
\hline WO kunst & 900 & 10 & 2,0 & gemiddeld \\
\hline
\end{tabular}

Bron: ROA 
Tabel 3.28

Verwachte vervangingsvraag per opleidingstype, 1995-2000

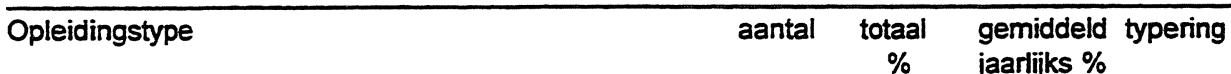

$\%$ jaarlijks \%

BASISONDERWIJS

Basisonderwijs

14

2,6

gemiddeld

MAVO, VBO

MAVO, onderbouw HAVONWO

$\begin{array}{llll}55.800 & 14 & 2,6 & \text { gemiddeld }\end{array}$

VBO landbouw en natuurlijke omgeving

17.300

2,7

gemiddeld

Bouwtechniek

1.200

21.100

13

2,4

gemiddeld

VBO installatietechniek

5.300

VBO motorvoertuigentechniek

7.000

VBO elektrotechniek

800

VBO grafische techniek

1.700

6.900

VBO textiet- en ledertechniek

6.900

VBO haven en vervoer

5.800

VBO administratie

VBO verkoop en handel

5.800
1.500

VBO verzorging

VBO bewaking

39.100

1.100

gemiddeld

gemiddeld

laag

laag

laag

erg laag

erg hoog

hoog

erg laag

erg laag

hoog

HAVONWO, MBORLW

HAVONWO bovenbouw

MBOLLW landbouw en natuurlijke omgeving

33.000

19.100

1.900

MBO technisch laboratorium

26.800

MBO/LLW bouwkunde

MBO/LLW weg-en waterbouwkunde

2.600

$M B O / L L W$ metaalkunde

9.400

3.100

MBO/LLW fijnmechanische techniek

12.300

6.700

MBO/LLW motorvoertuigentechniek

18.300

MBO/LLW elektrotechniek

MBO/LLW grafische techniek

6.100

5.900

2.000

MBO/LLW procestechniek

MBO/LLW textiet en ledertechniek

7.300

8.900

MBO/LLW haven en vervoer

34.300

4.400

MBO/LLW medisch laboratorium

64.000

MBO/LWW handel

13.500

MBO/LLW administratief

MBO toerisme en recreatie

700

3.500

MBO/LLW commercieel

MBO/LLW secretarieel

11.400

MBO bestuurlijk-juridisch

8.300

6.700

BO sociaal-culturee

31.500

MBOLLWW verzorging

7.800

MBO politie en defensie

12.000

11
14
14
16
12
16
20
14
11
13
16
14
12
20
19
19
15
20
15
4
10
12
17
12
14
13
15

$\begin{array}{ll}2,0 & \text { laag } \\ 2,6 & \text { gemiddeld } \\ 2,6 & \text { gemiddeld } \\ 3,0 & \text { gemiddeld } \\ 2,3 & \text { laag } \\ 3,0 & \text { gemiddeld } \\ 3,7 & \text { erg hoog } \\ 2,6 & \text { gemiddeld } \\ 2,1 & \text { laag } \\ 2,4 & \text { gemiddeld } \\ 3,0 & \text { gemiddeld } \\ 2,7 & \text { gemiddeld } \\ 2,3 & \text { laag } \\ 3,7 & \text { erg hoog } \\ 3,6 & \text { hoog } \\ 3,5 & \text { hoog } \\ 2,9 & \text { gemiddeld } \\ 3,7 & \text { erg hoog } \\ 2,8 & \text { gemiddeld } \\ 0,9 & \text { erg laag } \\ 1,9 & \text { laag } \\ 2,3 & \text { laag } \\ 3,2 & \text { hoog } \\ 2,3 & \text { laag } \\ 2,7 & \text { gemiddeld } \\ 2,4 & \text { gemiddeld } \\ 2,8 & \text { gemiddeld }\end{array}$


Tabel 3.28 (vervolg)

Verwachte vervangingsvraag per opleidingstype, 1995-2000

\begin{tabular}{|c|c|c|c|}
\hline Opleidingstype & aantal & $\begin{array}{c}\text { totaal } \\
\%\end{array}$ & $\begin{array}{l}\text { gemiddeld typering } \\
\text { jaarlijks \% }\end{array}$ \\
\hline
\end{tabular}

HBO

$\begin{array}{lrrrl}\text { HBO onderwijs } & 50.900 & 20 & 3,7 & \text { erg hoog } \\ \text { HBO tolk en vertaler } & 1.300 & 15 & 2,9 & \text { gemiddeld } \\ \text { HBO landbouw en milieukunde } & 2.300 & 12 & 2,3 & \text { laag } \\ \text { HBO technisch laboratorium } & 4.600 & 17 & 3,1 & \text { hoog } \\ \text { HBO (weg- en water)bouwkunde } & 5.700 & 16 & 3,0 & \text { gemiddeld } \\ \text { HBO werktuigbounwkunde } & 5.100 & 17 & 3,2 & \text { hoog } \\ \text { HBO elektrotechniek en technische informatica } & 4.600 & 11 & 2,1 & \text { laag } \\ \text { HBO haven en vervoer } & 5.400 & 19 & 3,5 & \text { hoog } \\ \text { HBO medisch laboratorium } & 2.300 & 11 & 2,0 & \text { laag } \\ \text { HBO verpleging en paramedisch } & 13.300 & 16 & 3,0 & \text { gemiddeld } \\ \text { HBO bedrijfseconomie } & 2.300 & 10 & 2,0 & \text { laag } \\ \text { HBO accountancy } & 5.500 & 20 & 3,6 & \text { erg hoog } \\ \text { HBO bedrijfsinformatica } & 2.900 & 10 & 1,9 & \text { laag } \\ \text { HBO toerisme en recreatie } & 400 & 6 & 1,1 & \text { erg laag } \\ \text { HBO commerciële economie } & 1.900 & 9 & 1,8 & \text { erg laag } \\ \text { HBO technische bedrijfskunde } & 1.200 & 9 & 1,8 & \text { erg laag } \\ \text { HBO bestuurlijk-juridisch } & 5.000 & 20 & 3,6 & \text { erg hoog } \\ \text { HBO sociaal-cultureel } & 18.300 & 16 & 3,0 & \text { gemiddeld } \\ \text { HBO kunst } & 7.200 & 15 & 2,9 & \text { gemiddeld } \\ \text { HBO politie en defensie } & 1.600 & 17 & 3,2 & \text { hoog }\end{array}$

wo

WO letteren

WO theologisch

WO landbouw en milieukunde

5.900
1.700

1.700
1.200

8.200

3.500

WO (weg- en water)bouwkunde

3.500
1.600

2.400

WO elektrotechniek en technische informatica

2.400
11.900

WO dier-, genees- en tandheelkunde

1.900

WO farmacie

WO econom(etr)ie en accountancy

$700 \quad 15$

$7.700 \quad 18$

$1.500 \quad 15$

$500 \quad 11$

$7.300 \quad 15$

WO informatica

WO juridisch

$1.300 \quad 13$

14.300

WO sociaal-cultureel

1.600

14
31
10
19
19
18
17
22
15
18
15
11
15
13
18
18

gemiddeld

erg hoog

laag

hoog

hoog

hoog

hoog

erg hoog

gemiddeld

hoog

gemiddeld

laag

gemiddeld

gemiddeld

hoog

hoog

Bron: ROA 


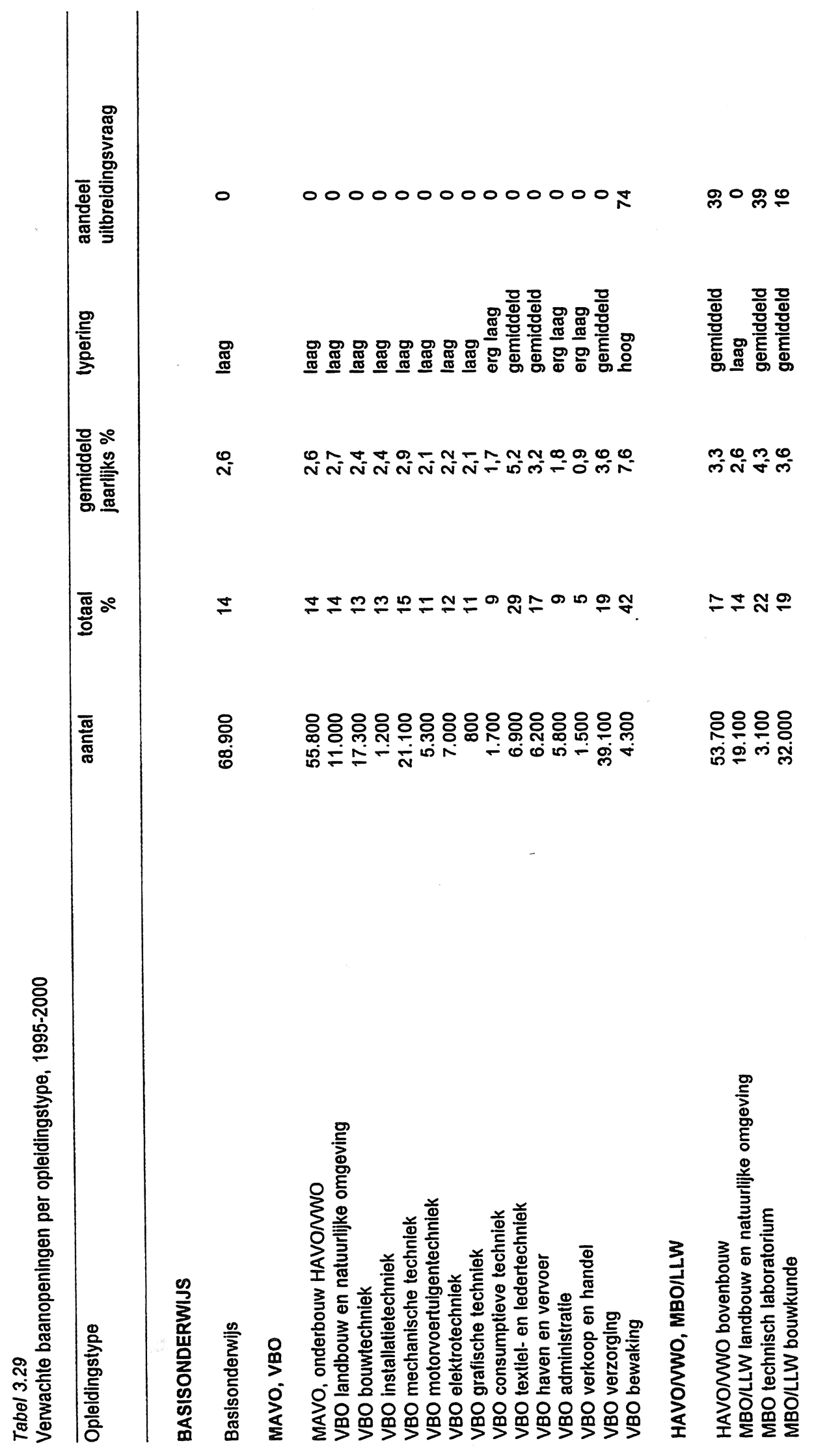




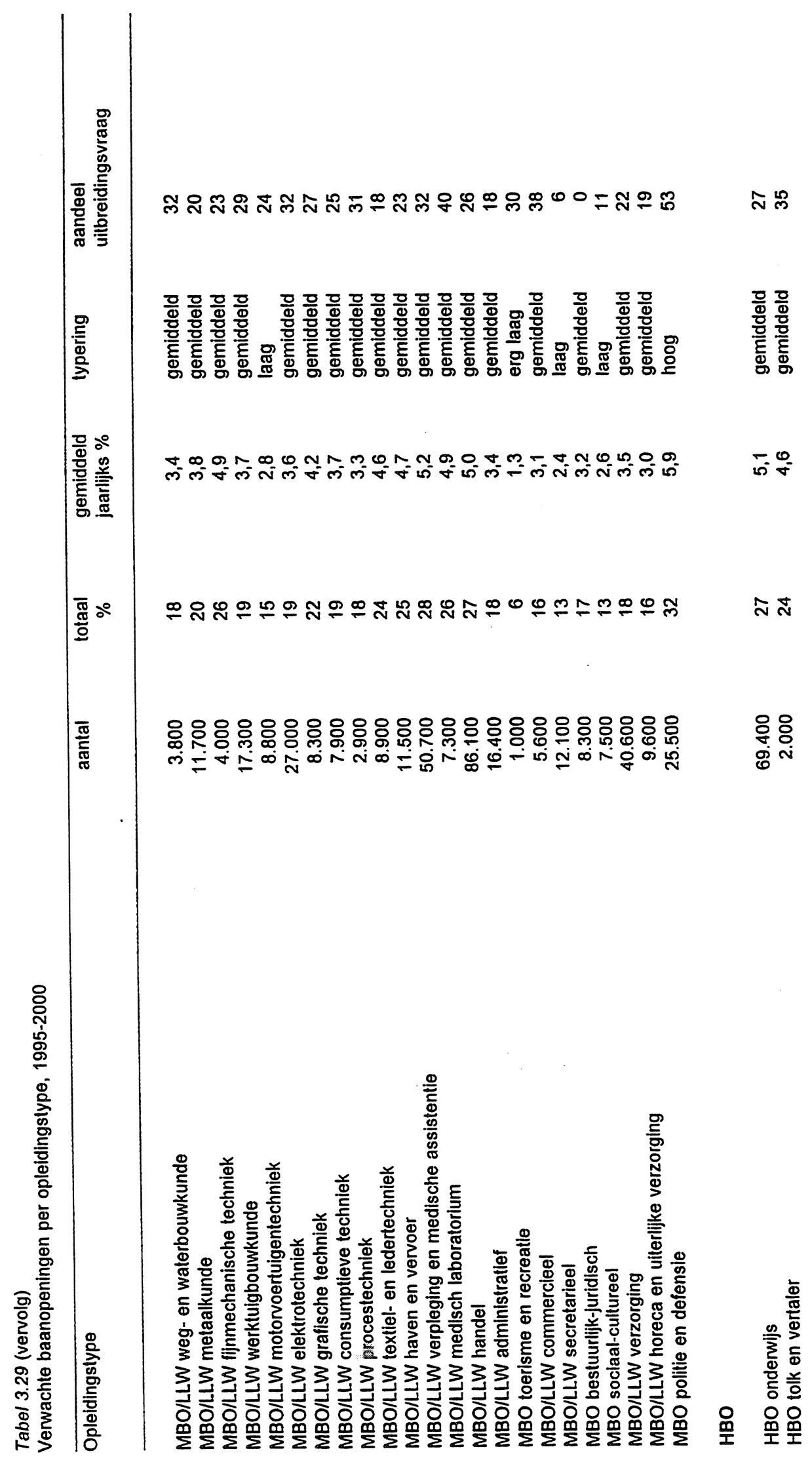




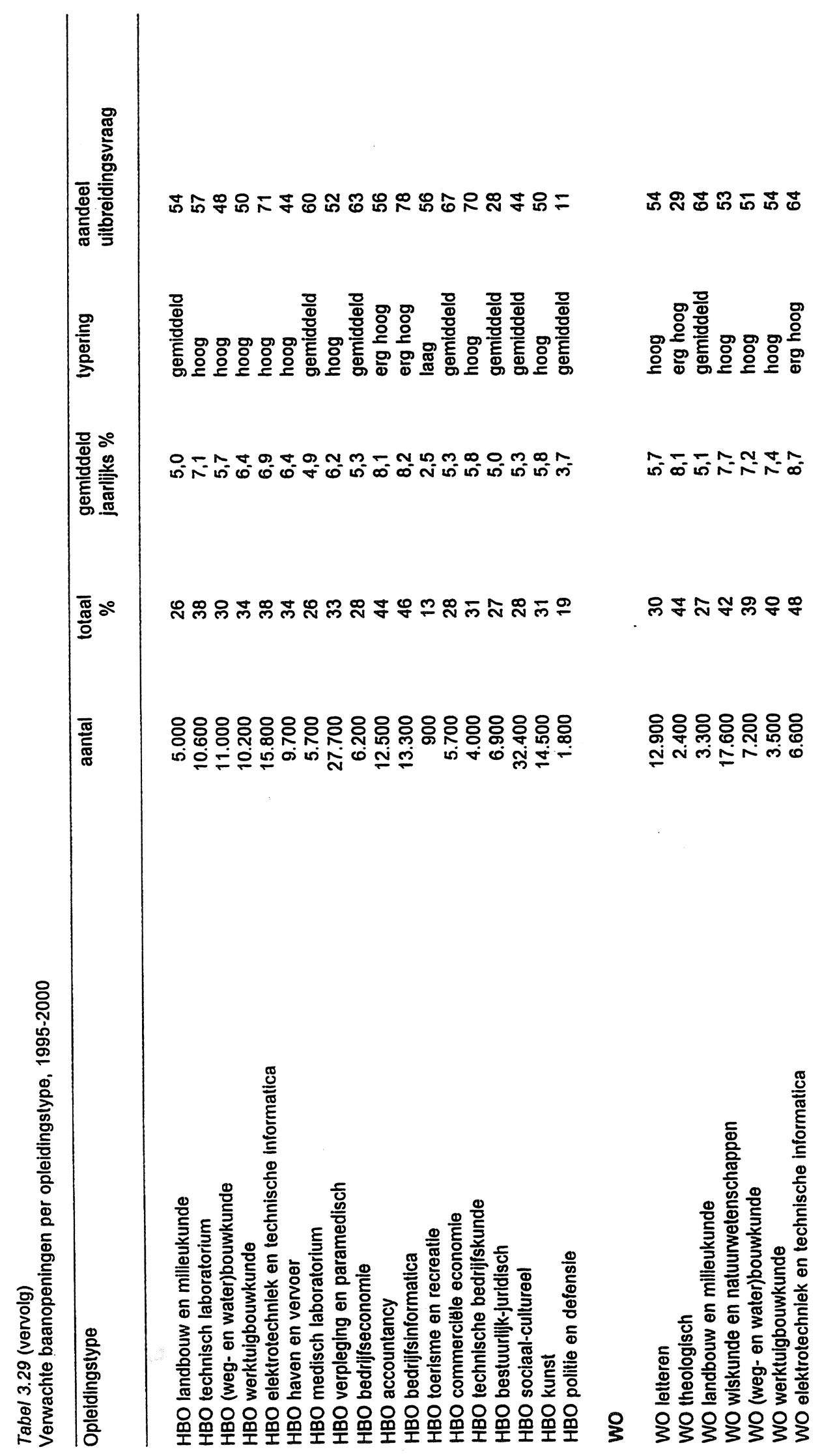




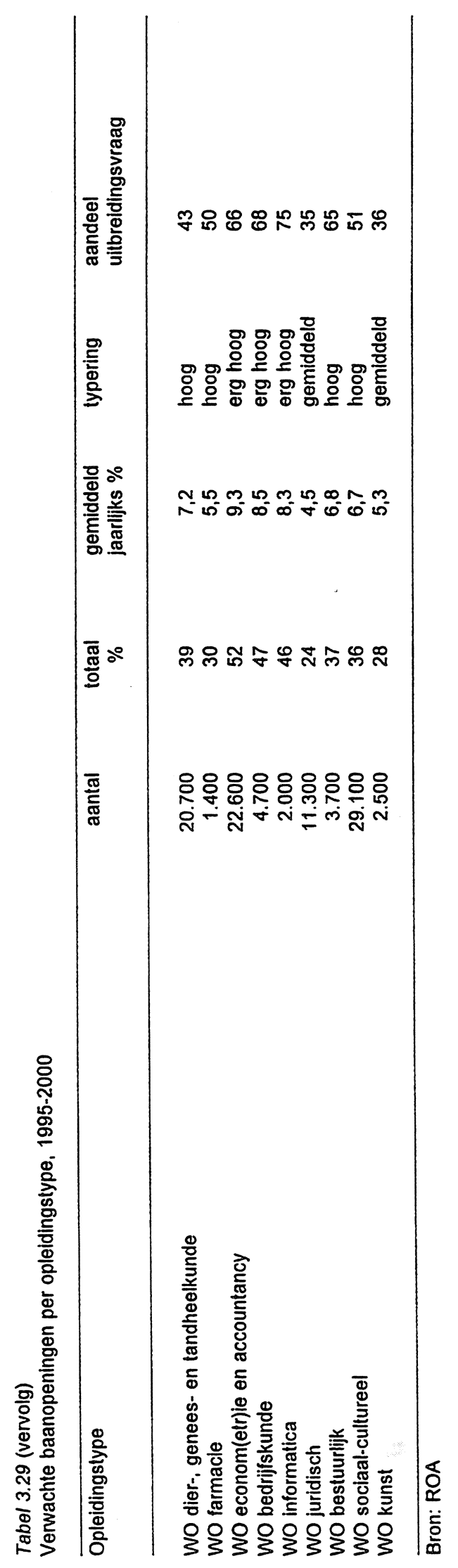


Tabel 3.30

Indicator toekomstige arbeidsmarktsituatie (ITA) en Indicator toekomstige kans op knelpunten in de personeelsvoorziening (ITKP) naar opleidingstype in 2000



\section{BASISONDERWIS}

Basisonderwijs

1,08 matig

1,22 zeer klein

MAVO, VBO

MAVO, onderbouw HAVOMWO

1,01 redelijk

VBO landbouw en natuurlijke omgeving

1,07 matig

1,07 matig

1,13 matig

VBO installatietechniek

VBO mechanische techniek

VBO motorvoertuigentechniek

VBO elektrotechniek

VBO grafische techniek

VBO consumptieve techniek

VBO textiel- en ledertechniek

1,04 redelijk

1,11 matig

1,01 redelijk

1,07 matig

1,29 slecht

1,07 matig

0,97 goed

VBO haven en vervoer

1,14 matig

1,22 slecht

VBO verkoop en handel

$\checkmark B O$ verzorging

VBO bewaking

0,99 goed

1,06 matig

$\begin{array}{ll}1,05 & \text { zeer klein } \\ 1,17 & \text { zeer klein } \\ 1,13 & \text { zeer klein } \\ 1,20 & \text { zeer klein } \\ 1,09 & \text { zeer klein } \\ 1,17 & \text { zeer klein } \\ 1,05 & \text { zeer klein } \\ 1,11 & \text { zeer klein } \\ 1,34 & \text { zeer klein } \\ 1,11 & \text { zeer klein } \\ 0,99 & \text { redelijk groot } \\ 1,21 & \text { zeer klein } \\ 1,20 & \text { zeer klein } \\ 1,02 & \text { klein } \\ 1,06 & \text { zeer klein } \\ & \end{array}$

HAVONWO, MBOILLW

HAVOMWO bovenbouw
MBO/LLW landbouw en natuurlijke omgeving
MBO technisch laboratorium
MBO/LLW bouwkunde
MBO/LLW weg- en waterbouwkunde
MBO/LLW metaalkunde
MBO/LLW fijnmechanische techniek
MBO/LLW werktuigbouwkunde
MBO/LLW motorvoertuigentechniek
MBO/LLW elektrotechniek
MBO/LLW grafische techniek
MBO/LLW consumptieve techniek
MBO/LLW procestechniek
MBO/LLW textiel- en ledertechniek
MBO/LLW haven en vervoer
MBO/LLW verpleging en medische assistentie
MBO/LLW medisch laboratorium
MBO/LWW handel
MBO/LLW administratief
MBO toerisme en recreatie
MBO/LLW commercieel
MBO/LLW secretarieel
MBO bestuurlijk-juridisch
MBO sOciaal-cultureel
MBO/LLW verzorging
MBO/LLW horeca en uiterijke verzorging
MBO politie en defensie

$\begin{array}{ll}1,13 & \text { matig } \\ 1,11 & \text { matig } \\ 1,06 & \text { matig } \\ 1,03 & \text { redelijk } \\ 1,07 & \text { matig } \\ 1,07 & \text { matig } \\ 0,93 & \text { goed } \\ 1,06 & \text { matig } \\ 1,22 & \text { slecht } \\ 1,06 & \text { matig } \\ 0,99 & \text { goed } \\ 1,06 & \text { matig } \\ 1,03 & \text { redelijk } \\ 1,00 & \text { goed } \\ 0,98 & \text { goed } \\ 1,00 & \text { goed } \\ 0,94 & \text { goed } \\ 1,05 & \text { redelijk } \\ 1,12 & \text { matig } \\ 1,26 & \text { slecht } \\ 1,10 & \text { matig } \\ 1,11 & \text { matig } \\ 0,91 & \text { goed } \\ 1,20 & \text { slecht } \\ 1,14 & \text { matig } \\ 1,07 & \text { matig } \\ 0,95 & \text { goed }\end{array}$

1,13 zeer klein

1,12 zeer klein

1,06 zeer klein

1,03 klein

1,07 zeer klein

1,07 zeer klein

0,93 groot

1,06 zeer klein

1,22 zeer klein

1,06 zeer klein

0,99 redelijk groot

1,06 zeer klein

1,03 klein

1,00 redelijk groot

0,98 redelijk groot

1,00 redelijk groot

0,94 groot

1,05 zeer klein

1,12 zeer klein

1,26 zeer klein

1,10 zeer klein

1,11 zeer klein

0,91 groot

1,20 zeer klein

1,14 zeer klein

1,07 zeer klein

0,95 groot 
Tabel 3.30 (vervolg)

Indicator toekomstige arbeidsmarktsituatie (ITA) en Indicator toekomstige kans op knelpunten in de personeelsvoorziening (ITKP) naar opleidingstype in 2000

\begin{tabular}{llll}
\hline Opleidingstype & ITA & $\begin{array}{l}\text { typering } \\
\text { arbeidsmarktsituatie }\end{array}$ & $\begin{array}{l}\text { TKP } \\
\text { typering } \\
\text { knelpunten }\end{array}$ \\
\hline
\end{tabular}

HBO

\begin{tabular}{|c|c|c|c|c|}
\hline HBO onderwijs & 0,93 & goed & 0,93 & groot \\
\hline $\mathrm{HBO}$ tolk en vertaler & 0,95 & goed & 0,95 & groot \\
\hline HBO landbouw en milieukunde & 1,07 & matig & 1,07 & zeer klein \\
\hline HBO technisch laboratorium & 0,85 & goed & 0,85 & groot \\
\hline HBO (weg- en water)bouwkunde & 0,83 & goed & 0,83 & groot \\
\hline HBO werktuigbouwkunde & 0,98 & goed & 0,98 & redelijk groot \\
\hline HBO elektrotechniek en technische informatica & 0,94 & goed & 0,94 & groot \\
\hline HBO haven en vervoer & 0,79 & goed & 0,79 & groot \\
\hline HBO medisch laboratorium & 0,91 & goed & 0,91 & groot \\
\hline HBO verpleging en paramedisch & 0,94 & goed & 0,94 & groot \\
\hline HBO bedrijfseconomie & 1,08 & matig & 1,08 & zeer klein \\
\hline HBO accountancy & 0,73 & goed & 0,73 & groot \\
\hline HBO bedrijfsinformatica & 0,77 & goed & 0,77 & groot \\
\hline HBO toerisme en recreatie & 1,10 & matig & 1,10 & zeer klein \\
\hline HBO commerciële economie & 1,22 & slecht & 1,22 & zeer klein \\
\hline HBO technische bedrijfskunde & 1,13 & matig & 1,13 & zeer klein \\
\hline HBO bestuurlijk-juridisch & 0,92 & goed & 0,92 & groot \\
\hline HBO sociaal-cultureel & 0,99 & goed & 0,99 & redelijk groot \\
\hline HBO kunst & 0,91 & goed & 0,91 & groot \\
\hline HBO politie en defensie & 0,99 & goed & 0,99 & redelijk groot \\
\hline \multicolumn{5}{|l|}{ wo } \\
\hline WO letteren & 1,07 & matig & 1,07 & zeer klein \\
\hline WO theologisch & 0,79 & goed & 0,79 & groot \\
\hline WO landbouw en milieukunde & 1,00 & goed & 1,00 & redelijk groot \\
\hline WO wiskunde en natuurwetenschappen & 0,83 & goed & 0,83 & groot \\
\hline WO (weg- en water)bouwkunde & 0,76 & goed & 0,76 & groot \\
\hline WO werktuigbouwkunde & 1,00 & goed & 1,00 & redelijk groot \\
\hline WO elektrotechniek en technische informatica & 0,86 & goed & 0,86 & groot \\
\hline WO dier-, genees- en tandheelkunde & 0,83 & goed & 0,83 & groot \\
\hline WO farmacie & 0,98 & goed & 0,98 & redelijk groot \\
\hline WO econom(etr)ie en accountancy & 0,88 & goed & 0,88 & groot \\
\hline WO bedrijfskunde & 1,03 & redelijk & 1,03 & klein \\
\hline WO informatica & 0,93 & goed & 0,93 & groot \\
\hline WO juridisch & 1,10 & matig & 1,10 & zeer klein \\
\hline WO bestuurlijk & 0,88 & goed & 0,88 & groot \\
\hline WO sociaal-cultureel & 0,97 & goed & 0,97 & redelijk groot \\
\hline WO kunst & 1,19 & slecht & 1,19 & zeer klein \\
\hline
\end{tabular}

Bron: ROA 

Bijlage A 


\section{Bijlage A Bedrijfssector-, beroepsklasse- en opleidings- indeling}

Tabel A.1

Bedrijfssectoren op basis van SBI'78

\begin{tabular}{ll}
\hline Bedrijfssector & SBI'78-codes \\
\hline & \\
Landbouw en visserij & $01-03$ \\
Voedings- en genotmiddelenindustrie & 20,21 \\
Overige industrie & $22-27,32$ \\
Chemie & $29-31$ \\
Metaal en elektrotechniek & $33-39$ \\
Energie & $11-19,28,40$ \\
Bouw & $51,52,83$ \\
Handel & $61-66$ \\
Transport, opslag en communicatie & $71-77$ \\
Overige commerciële dienstverlening & $67,68,84,85,98,99$ \\
Bank- en verzekeringswezen & 81,82 \\
Kwartaire diensten & $91,93-97$ \\
Overheid & 90,92 \\
\end{tabular}

Tabel A.2

Bedrijfssectoren op basis van SBl'93

\begin{tabular}{ll}
\hline Bedrijfssector & SBl'93-codes \\
\hline & \\
Landbouw en visserij & $01,02,05$ \\
Voedings- en genotmiddelenindustrie & 15,16 \\
Overige industrie & $17-22,26$ \\
Chemie & 24,25 \\
Metaal en elektrotechniek & $27-36$ \\
Energie & $10,11,14,23,40,41$ \\
Bouw & 45,70 \\
Handel & $50101,50102,50105,503$, \\
Transport, opslag en communicatie & $50401,505,51,521-526$ \\
Overige commerciële dienstveriening & $60-64$ \\
Bank- en verzekeringswezen & $50103,50104,502,50402,527$, \\
Kwartaire diensten & $55,71,72,74,90,924,93,95$ \\
Overheid & $65-67$ \\
& $73,85,91,921-923,925-927$ \\
\hline
\end{tabular}


Tabel A.3

Beroepsklassen

Beroepsklasse

ROA-code

Beroepsgroepen

\section{PEDAGOGISCHE BEROEPEN}

Leerkrachten basis- en speciaal onderwijs

0131

Docenten voortgezet onderwijs

Onderwijskundigen

Sportdocenten en -instructeurs

0132

0133

0221

$133,134,135$

131,132

139

CULTURELE BEROEPEN

Taalkundigen, tolken en vertalers

Geestelijke verzorgers

Fotografen, ontwerpers en vormgevers

Regisseurs en kunstenaars

1131

1231

1321

1331

\section{AGRARISCHE BEROEPEN}

Uitvoerend agrarisch personeel

Bedrijfsleiders in de landbouw

Landbouw en milieu-ingenieurs

TECHNISCHE, AMBACHTS- EN INDUSTRIEBEROEPEN

Heftruckrijders

Machinisten bouw en industrie

Ondernemers, uitvoerders en bedrijfskundigen

Technische en medische vertegenwoordigers

Technisch tekenaars

Chemo-technici en laboranten

Natuurkundigen, technologen en statistici

Voedings- en genotmiddelenbereiders

Bakkers en chocolademakers

Productiepersoneel textielindustrie

Stoffeerders en ledenwarenmakers

Patroonmakers, naaiers en zeilmakers

Houtzagers, papier- en kartonmakers

Timmerlieden

Productiepersoneel grafische industrie

Productiepersoneel chemische industrie

Vakkrachten metaalindustrie

Metaalbewerkers

Lassers, constructeurs en edelsmeden

Machinebank-, plaatwerkers en smeden

Instrumentmakers en onderhoudsmonteurs

Automonteurs en -herstellers

Werktuigbouwkundigen

Hogere werktuigkundigen

Monteurs en controleurs elektrotechnische producten
2011

2012

2031

3011

3012

3021

3022

3023

3024

3031

3111

3112

3211

3212

3213

3311

3312

3411

3511

3611

3612

3613

3614

3615

3621

3622

3631

3711
195

141,149

162,163

$161,171-175,591$

$621-624,629,632$

$601,602,609,611-613$,

631,680

053

979

$961,969,972-974$

024, 028, 211-214, 701,

702

461

032

014, 036

011-013, 026, 027, 029,

$051,052,081,082,085$

$771-775,777,779$,

781-783

776

$751-756,759,760$

$796,801-803$

791-795, 799

$731-734,910$

$811,812,818,819,941$,

$942,954,958$

921-927, 929

$741-745,749$

$711-713,721-729$

$834-836,839,846,849$

$872,874,879,880$

$820,831-833,841,873$

$842,844,845$

843

$035,037,039,043$

025

$853,944,949$ 
Tabel A.3 (vervolg)

Beroepsklassen

\begin{tabular}{|c|c|c|}
\hline Beroepsklasse & ROA-code & Beroepsgroepen \\
\hline Monteurs energievoorziening & 3712 & 857 \\
\hline Monteurs en controleurs elektrotechnische installaties & 3721 & $\begin{array}{l}851,852,854-856,859 \\
860\end{array}$ \\
\hline Elektrotechnische opzichters en uitvoerders & 3722 & 034 \\
\hline Elektrotechnische constructeurs en ingenieurs & 3731 & 023 \\
\hline Productiepersoneel aardewerk- en glasindustrie & 3811 & $\begin{array}{l}891-894,899,901,902 \\
939,943\end{array}$ \\
\hline Metselaars en stukadoors & 3911 & 951,955 \\
\hline Betonwerkers en glaszetters & 3912 & $952,953,956,957$ \\
\hline Schilders & 3913 & 931 \\
\hline Loodgieters en installateurs & 3914 & 871 \\
\hline Wegenbouwvakkrachten en buizenleggers & 3915 & 959, 991-993, 998, 999 \\
\hline Bouwkundige projectleiders & 3921 & 033 \\
\hline Architecten en bouwkundige ingenieurs & 3931 & $021,022,031$ \\
\hline \multicolumn{3}{|l|}{ TRANSPORTBEROEPEN } \\
\hline Expeditie-medewerkers & 4011 & 971 \\
\hline Vissers en jachtopzieners & 4111 & 641,649 \\
\hline Scheepsdek- en machinekamerpersoneel & 4112 & 981,982 \\
\hline Schippers, officieren en loodsen & 4121 & 042 \\
\hline Chauffeurs en spoorwegpersoneel & 4211 & $351,360,983-986,989$ \\
\hline Vliegers, verkeersleiders en expediteurs & 4321 & 041,359 \\
\hline \multicolumn{3}{|l|}{ MEDISCHE EN PARAMEDISCHE BEROEPEN } \\
\hline Verpleegkundigen & 5021 & 071,073 \\
\hline Leerling-verpleegkundigen, zieken- en kraamverzorgenden & 5022 & 072,074 \\
\hline Dokters-, tandarts- en dierenartsassistenten & 5023 & 593 \\
\hline Opticiens en apothekersassistenten & 5024 & 068,075 \\
\hline Paramedische en verwante functies & 5025 & $064,069,079$ \\
\hline Fysio-, arbeids- e.a. bewegingstherapeuten & 5031 & 076 \\
\hline Analisten en laboranten & 5032 & 054,077 \\
\hline Artsen, medische specialisten en apothekers & 5033 & 061,067 \\
\hline Dierenartsen en diergeneeskundigen & 5034 & 065 \\
\hline Tandheelkundigen & 5035 & 063 \\
\hline \multicolumn{3}{|l|}{ ECONOMISCH-ADMINISTRATIEVE BEROEPEN } \\
\hline Hogere leidinggevenden financiën, verkoop e.d. & 6031 & 219 \\
\hline Postbestellers en -sorteerders & 6111 & 370 \\
\hline Operators en datatypisten & 6112 & $322,341,342$ \\
\hline Leidinggevend administratief personeel & 6121 & 300 \\
\hline Secretaresses en typisten & 6122 & 321 \\
\hline Bibliotheek- en archiefmedewerkers & 6123 & 395 \\
\hline Administrateurs en bankemployés & 6124 & 331,339 \\
\hline Commercieel-administratieve employés & 6125 & $391-393$ \\
\hline Receptionisten, telefonisten en enquêteurs & 6126 & $380,394,399$ \\
\hline Programmeurs en systeemanalisten & 6131 & 083,084 \\
\hline Economen en accountants & 6132 & 090,110 \\
\hline Verkooppersoneel & 6211 & $481,482,490$ \\
\hline Winkeliers en handelaars & 6221 & $\begin{array}{l}352,401,402,411,412, \\
421,422,431-449\end{array}$ \\
\hline
\end{tabular}


Tabel A.3 (vervolg)

Beroepsklassen

\begin{tabular}{lll}
\hline Beroepsklasse & ROA-code & Beroepsgroepen \\
\hline Filiaalhouders, inkopers en vertegenwoordigers & 6222 & $451,452,462,471-473$ \\
Beleidsmedewerkers en hoofdambtenaren & 6331 & $201,202,310$ \\
Advocaten, rechters en notarissen & 6332 & $121,122,129$ \\
SOCIAAL-CULTURELE BEROEPEN & & \\
& & \\
Journalisten en presentatoren & 7021 & $151,159,179$ \\
Bibliothecarissen en archivarissen & 7031 & 191 \\
Arbeidsconsulenten en personeelsdeskundigen & 7032 & 194 \\
Maatschappelijk werkers & 7033 \\
Sociale wetenschappers & 7034 & 193 \\
Huishoudkundige voorlichters & 7035 & 192 \\
VERZORGENDE EN DIENSTVERLENENDE BEROEPEN & & \\
Keuken- en serveerpersoneel & & \\
Leidinggevenden horeca & 8111 & 531,532 \\
Portiers en schoonmaakpersoneel & 8121 & $501,502,511-514,518$, \\
Kinder-, gezins- en bejaardenverzorgenden & 519,520 \\
Kappers en schoonheidsSpecialisten & 8211 & $541,551,552,560,592$, \\
OPENBARE ORDE- EN VEILIGHEIDSBEROEPEN & 599 \\
Politie en beveiligingspersoneel & & 542 \\
Beroepsmilitairen & & 570 \\
\hline
\end{tabular}


Tabel A.4

Opleidingstypen

Opleidingstype

SOl-codes

\section{BASISONDERWIJS}

Basisonderwijs

00000-20199

MAVO, VBO

MAVO, onderbouw HAVOMWO

30100-30199

VBO landbouw en natuurlijke omgeving

32100-32999

VBO bouwtechniek

VBO installatietechniek

$33610-33615,33617-33629$,

$33810-33815,33817-33829$

VBO mechanische techniek

VBO motorvoertuigentechniek

33616,33816

33630-33639

VBO elektrotechniek

33641

33650-33659

VBO grafische techniek

33660-33669

33676, 33677

VBO consumptieve techniek

VBO textiel- en ledertechniek

$33673,33685,33873,33885$

VBO haven en vervoer

VBO administratie

34100-34999

VBO verkoop en handel

VBO verzorging

36130-36139

$36150-36159$

VBO bewaking

$38100-38999$

$39100-39499$

\section{HAVONWO, MBORLW}

HAVOMWO bovenbourw

MBO/LLW landbouw en natuurlijke omgeving

$40100-40199$

$42100-42999$

$43100-43199$

MBO technisch laboratorium

MBO/LLW bouwkunde

MBO/LLW weg-en waterbouwkunde

MBO/LLW metaalkunde

$43610-43619,43810-43819$

$43620-43629,43820-43829$

$43630-43634,43636-43639$,

43830-43834, 43836-43839

MBO/LLW fijnmechanische techniek

MBO/LLW werktuigbouwkunde

MBO/LLW motorvoertuigentechniek

MBO/LLW elektrotechniek

MBO/LLW grafische techniek

MBO/LLW consumptieve techniek

MBO/LLW procestechniek

MBO/LLW textiel- en ledertechniek

$M B O / L L W$ haven en vervoer

$M B O / L W W$ verpleging en medische assistentie

43635,43835

$43640,43642-43649,43840$,

$43842-43849$

43641,43841

$43650-43659,43850-43859$

43663-43668, 43863-43868

$43676-43677,43876-43877$

43678,43878

$43673,43685,43873,43885$

44100-44999

$45100-45199,45400-45499$

45200-45299

$46138,46150-46180$

MBO/LLW hande

MBO/LLW administratief

MBO toerisme en recreatie

46133

46142

46148

$46131,45300-45399$

MBO/LW secretariee

MBO bestuurlijk-juridisch

MBO sociaal-cultureel

46600-46699

$47100-47199$

$48100-48199,48400-48499$, $48600-48699$ 
Tabel A.4 (vervolg)

Opleidingstypen

\begin{tabular}{|c|c|}
\hline Opleidingstype & SOl-codes \\
\hline $\begin{array}{l}\text { MBO/LLW horeca en uiterlijke verzorging } \\
\text { MBO politie en defensie }\end{array}$ & $\begin{array}{l}48300-48399 \\
49100-49499\end{array}$ \\
\hline \multicolumn{2}{|l|}{ HBO } \\
\hline $\begin{array}{l}\text { HBO onderwijs } \\
\text { HBO tolk en vertaler } \\
\text { HBO landbouw en milieukunde } \\
\text { HBO technisch laboratorium } \\
\text { HBO (weg- en water)bouwkunde } \\
\text { HBO werktuigbouwkunde } \\
\text { HBO elektrotechniek en technische informatica } \\
\text { HBO haven en vervoer } \\
\text { HBO medisch laboratorium } \\
\text { HBO verpleging en paramedisch } \\
\text { HBO bedrijfseconomie } \\
\text { HBO accountancy } \\
\text { HBO bedrifsinformatica } \\
\text { HBO toerisme en recreatie } \\
\text { HBO commerciële economie } \\
\text { HBO technische bedrijfskunde } \\
\text { HBO bestuurlijk-juridisch } \\
\text { HBO sociaal-cultureel } \\
\text { HBO kunst } \\
\text { HBO politie en defensie }\end{array}$ & $\begin{array}{l}50600-50699,60600-60699 \\
51100-51199 \\
52100-52999 \\
53100-53199 \\
53610-53629,53810-53829 \\
53640-53649,53840-53849 \\
53650-53659 \\
54100-54999 \\
55200-55299 \\
55100-55199,55400-55499 \\
56110 \\
56133 \\
56135 \\
56142 \\
56148 \\
56200-56299 \\
56600-56699 \\
57100-57199 \\
58600-58699 \\
59100-59499\end{array}$ \\
\hline \multicolumn{2}{|l|}{ wo } \\
\hline wo letteren & $\begin{array}{l}61100-61199,70621-70623 \\
70628,70666,71181\end{array}$ \\
\hline WO theologisch & $61600-61699,70627$ \\
\hline WO landbouw en milieukunde & $62100-62999,72175,72220$ \\
\hline WO wiskunde en natuurwetenschappen & $\begin{array}{l}63100-63199,70631-70639 \\
73100-73199\end{array}$ \\
\hline WO (weg-en water)bouwkunde & $\begin{array}{l}63610-63629,63810-63829 \\
73618,73623\end{array}$ \\
\hline WO werktuigbouwkunde & $63640-63649,63840-63849$ \\
\hline WO elektrotechniek en technische informatica & $63650-63659,73651-73655$ \\
\hline WO dier-, genees- en tandheelkunde & $65100-65199,70671,75100-75199$ \\
\hline WO farmacie & $65200-65299,75200-75299$ \\
\hline WO econom(etr)ie en accountancy & $\begin{array}{l}66110,66133,66140-66148,66210 \\
66240,70661,76110,76120,76133\end{array}$ \\
\hline WO bedrijfskunde & $66120,66220,76220$ \\
\hline WO informatica & 66135,76135 \\
\hline wO juridisch & $66611-66619,76618$ \\
\hline WO bestuurlijk & $66620-66699,76620-76699$ \\
\hline WO sociaal-cultureel & $67100-67199,70663$ \\
\hline WO kunst & $\begin{array}{l}68600-68699,60680-60689 \\
70685-70688\end{array}$ \\
\hline
\end{tabular}

